\title{
Investigation of the Rotokawa Geothermal System and Feasibility of Supercritical Fluid Production within the TVZ through Supercritical TOUGH2 Numerical Modeling.
}

Benjamin Carson

\author{
A Thesis \\ Presented to the University of Victoria Wellington \\ In fulfillment of the \\ Thesis requirement of
}

Masters of Mathematics

Wellington, New Zealand 2018

(C)Benjamin Carson 2018

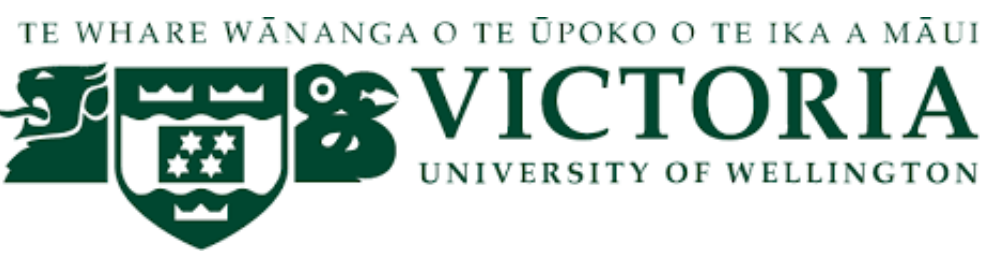




\section{Abstract}

A single fault process model was created to test the sensitivity of each TOUGH2 rock parameter on the convection flow rate and fluid enthalpy within a simulated fault. With a fixed temperature base the single fault process model found a negative correlation with the fault permeability and convection fluid enthalpy and a positive liner increases in mass flow with fault area.

Next a large scale Supercritical TOUGH2 model was built to simulate the entire Rotokawa geothermal system incorporating findings of the fault process model. The single porosity model $20 \times 10 \times 6 \mathrm{~km}$ with 20 layers and 57,600 grid blocks. Unlike previous models of the Rotokawa reservoir and larger scale TVZ numerical models a fixed temperature base with a no flow boundary was used to represent the brittle ductile transition. The model permeability below the currently explored reservoir was bounded by 3-D magnetologic data. Lower restivity was given higher bulk permeability.

The model resulted in a comparable temperature and pressure match to the Rotokawa natural state conditions. Convection of supercritical fluid reached depths shallower than $-4500 \mathrm{mRSL}$ but only occurred in zones with a bulk vertical permeability less than $2 \mathrm{mD}$.

Further modeling work with a supercritical wellbore coupled reservoir model will be need to evaluate the potential deliverability of a super critical well from the Rotokawa geothermal system. Additionally, technology will need to be developed in exploration, drilling, completions and geothermal plant surface facilities to handle the high temperature and highly corrosive nature of the supercritical fluids before commercial exploitation of a supercritical reservoirs in the Taupo Volcanic Zone can occur. 


\section{Table of Contents}

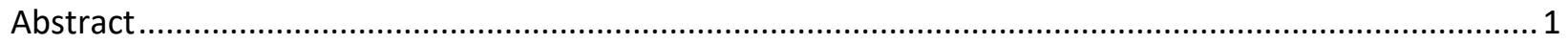

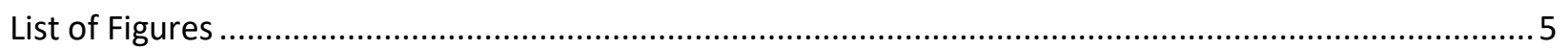

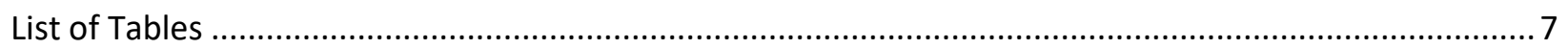

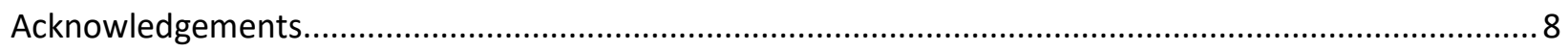

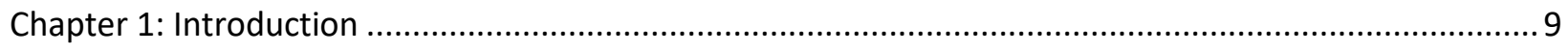

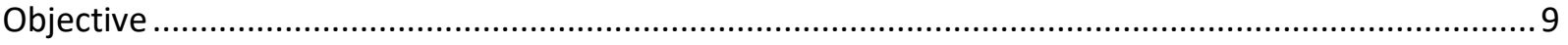

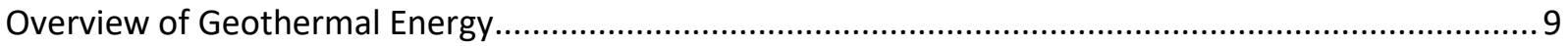

Geothermal Systems and Power Generation …......................................................................... 9

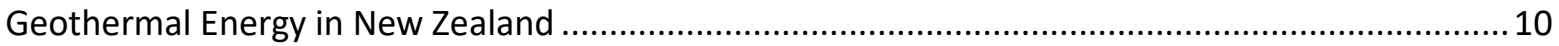

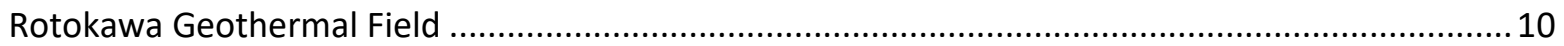

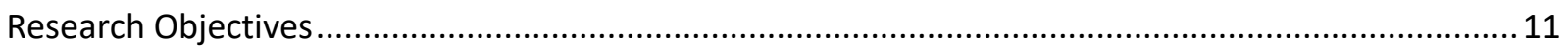

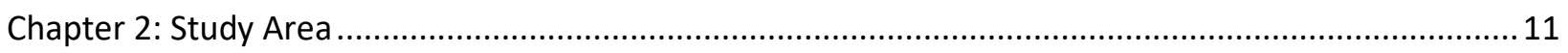

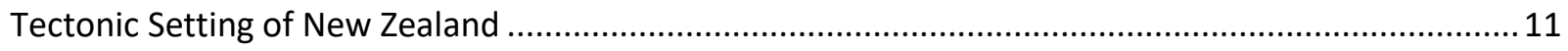

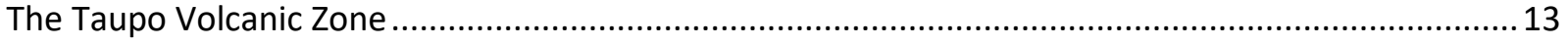

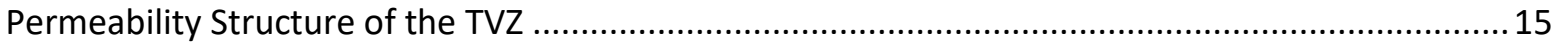

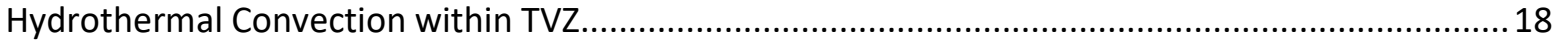

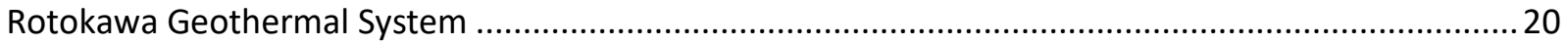

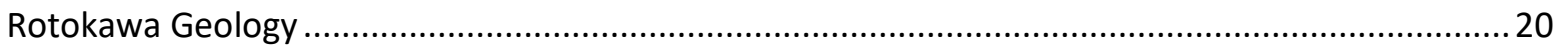

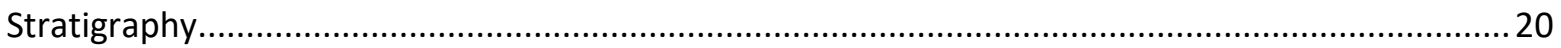

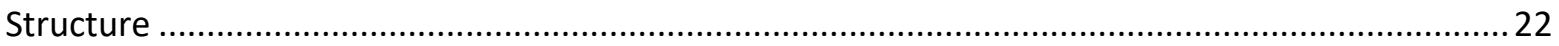

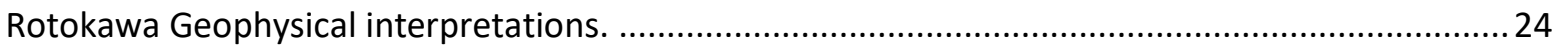

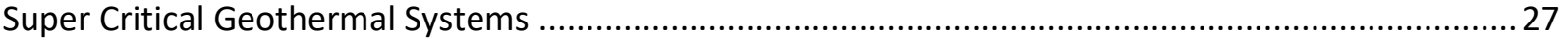

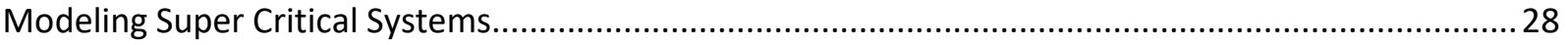

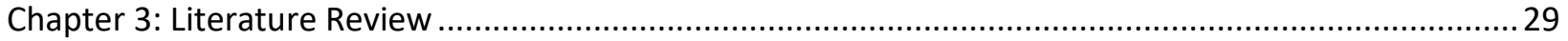

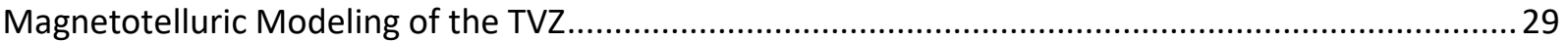

Using array MT data to image the crustal resistivity structure of the southeastern Taupo Volcanic

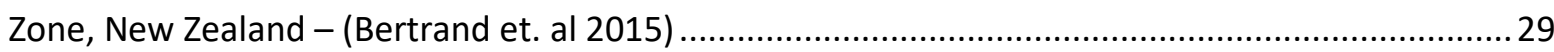

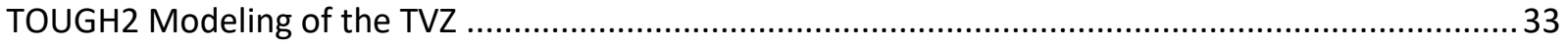

Factors Controlling Large-Scale Convective Geothermal systems in the Taupo Volcanic Zone (TVZ),

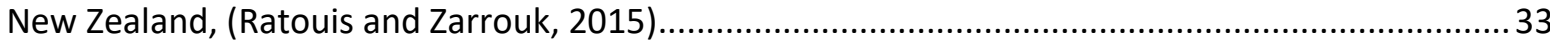

Three-dimensional model of the deep geothermal resources in the Taupo-Reporoa Basin (TRB),

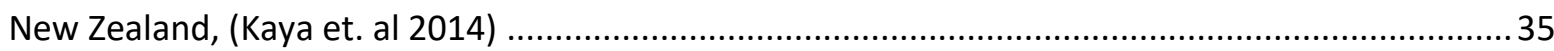


Numerical Modelling of the Influence of Geology and Groundwater Recharge on Geothermal Systems in the central TVZ (S. C. Pearson-Grant, S. D. Milicich, P. A. White and W. M. Kissling) .......37

Rotokawa Reservoir Modeling

Case Study: Development of a Numerical Model by a Multi-Disciplinary Approach, Rotokawa

Geothermal Field, New Zealand, (Bowyer and Holt, 2010) ........................................................ 40

Chapter 4: Reservoir Modeling Methodology .................................................................................. 42

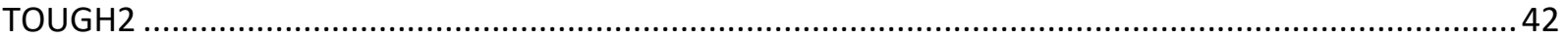

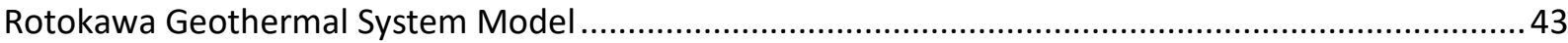

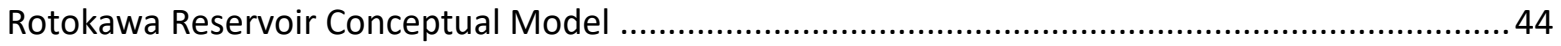

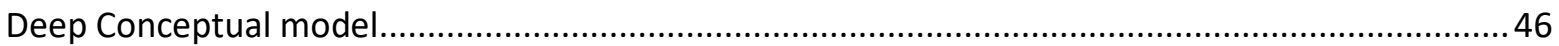

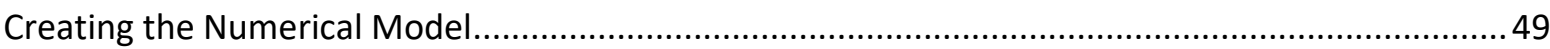

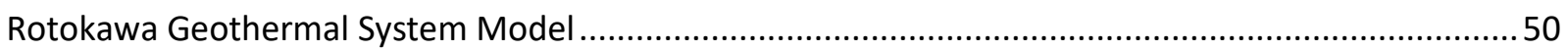

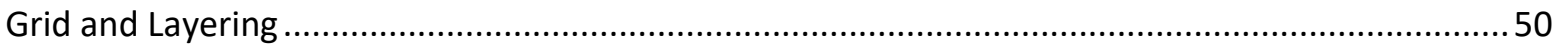

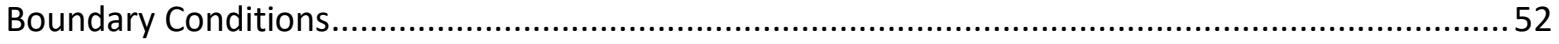

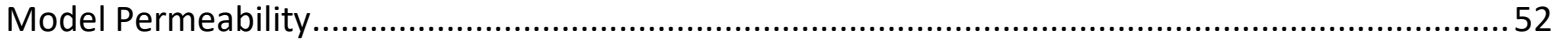

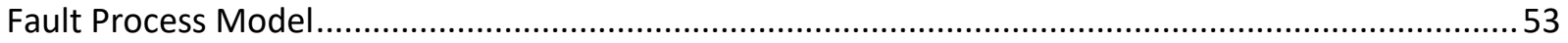

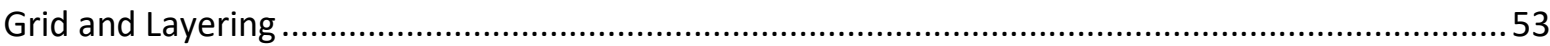

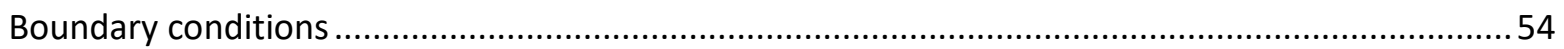

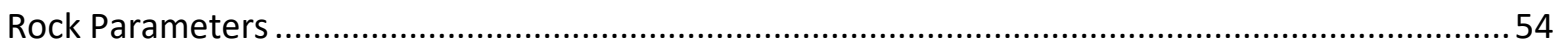

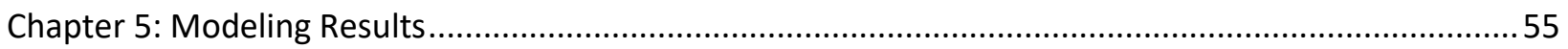

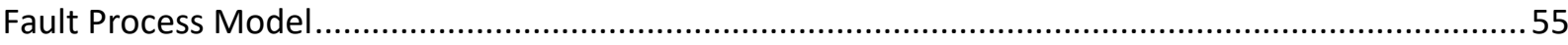

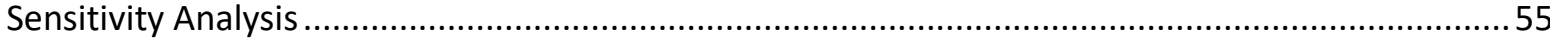

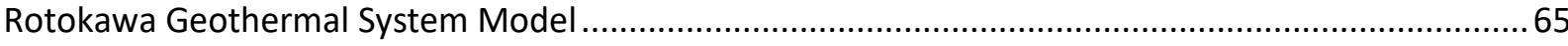

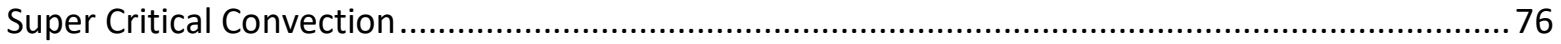

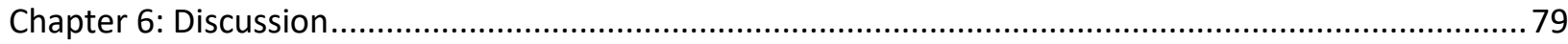

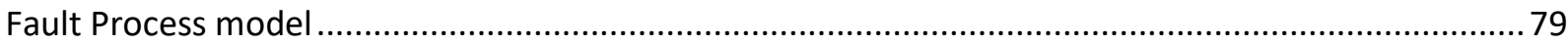

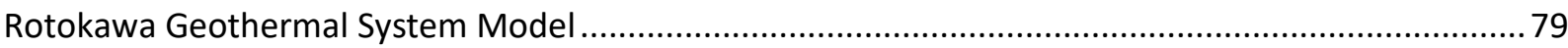

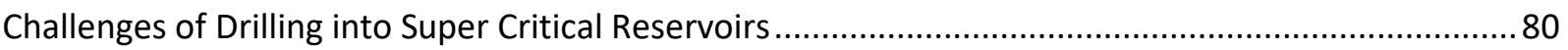

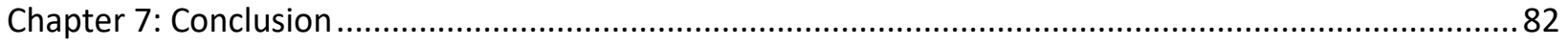

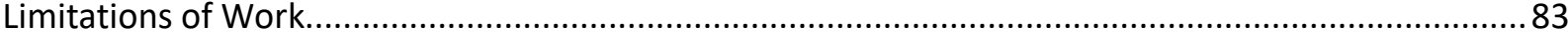

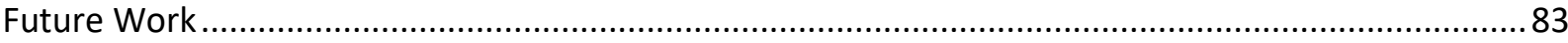

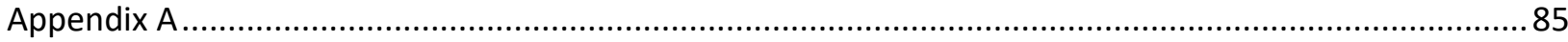

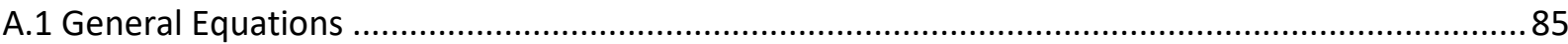

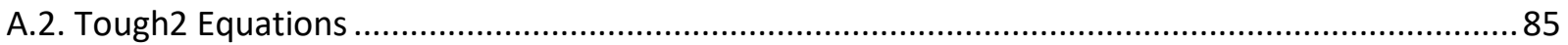




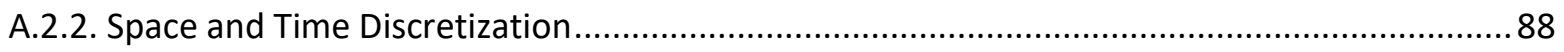

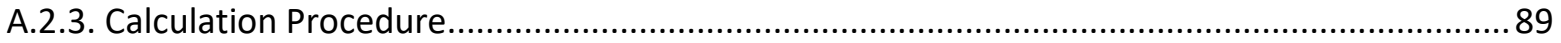

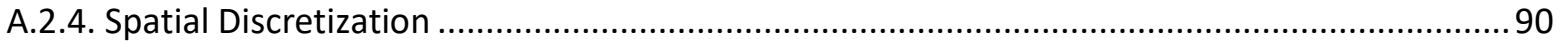

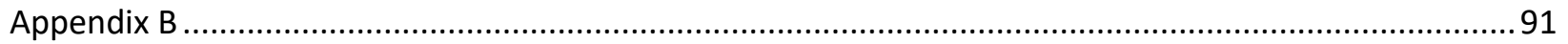

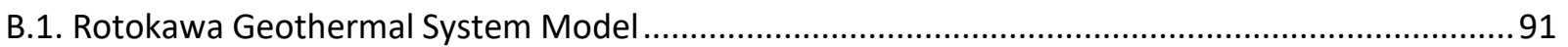

B.1.1. Rotokawa Geothermal System Model Layers........................................................................91

B.1.2. Model RK38 Rock Type at Each Layer ............................................................................. 91

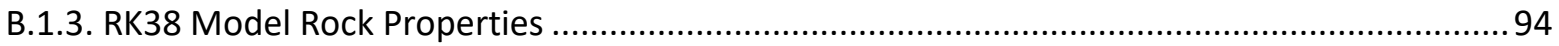

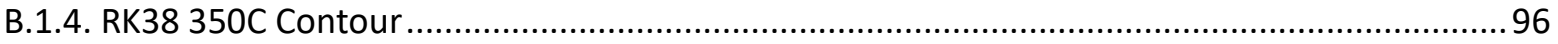

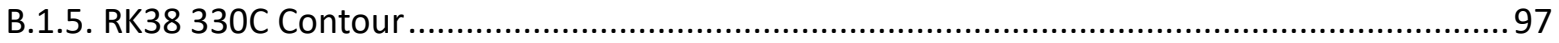

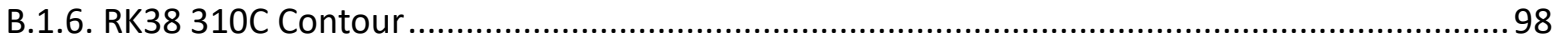

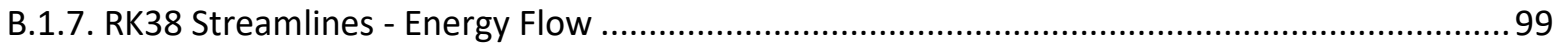

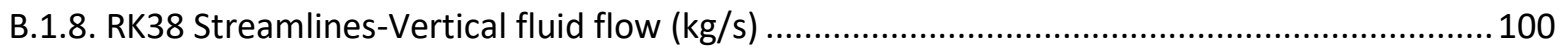

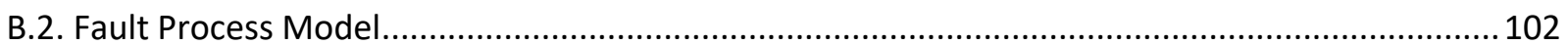

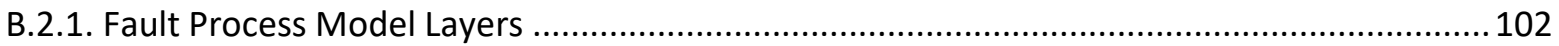

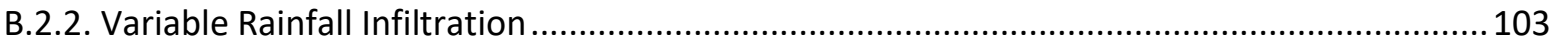

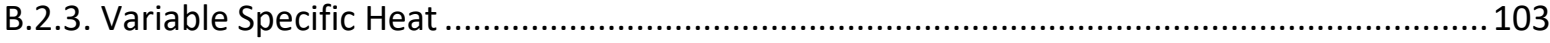

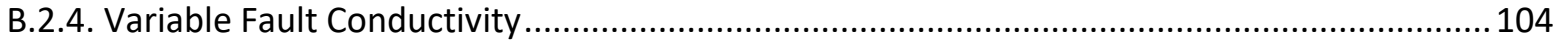

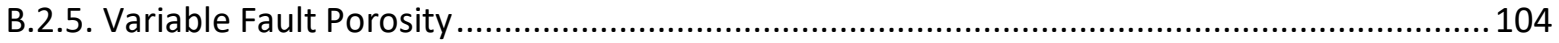

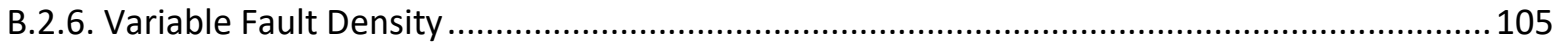

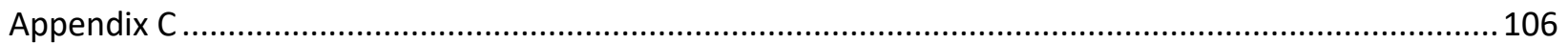

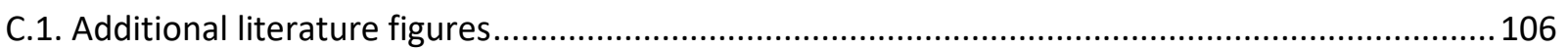

C.1.1. TVZ Geothermal Field Fault and Fracture Trends ...........................................................106

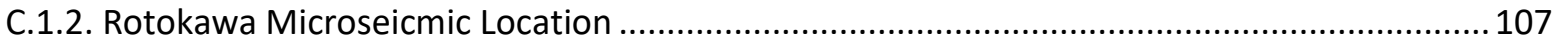

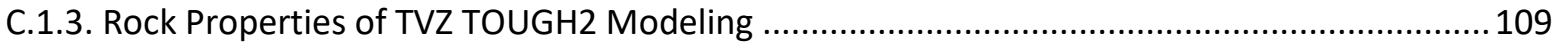

C.1.4. Helium and carbon isotopes in gas, and zoning in non-reactive gases (Ar, N) ....................110

C.1.5. Geologic structure and residual gravity map..................................................................111 


\section{List of Figures}

Figure 1: Current Tectonic setting of northern New Zealand............................................................ 12

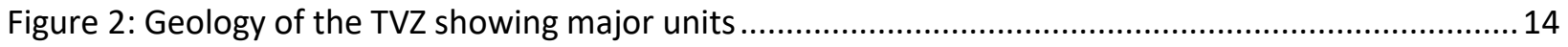

Figure 3: Figure 2: Structural elements of the Taupo Rift. ................................................................ 17

Figure 4: Conceptual model of the deep controls on high enthalpy New Zealand geothermal systems...19 Figure 5:Cross-section of the Rotokawa Geothermal Field ( $A-A^{\prime}$ as shown in Figure 6$)$ showing geological

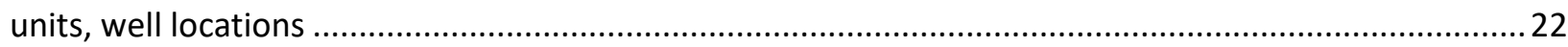

Figure 6: Map of the Rotokawa Geothermal Field showing active faults.............................................23

Figure 7: SW-NE MT cross-section (B-Bas shown in Fig. 3). ...............................................................25

Figure 8: A. MEQ events shown in relation to wells. Most located between injection and production ....26

Figure 9: Temperature and effective confining stress (depth) conditions for the base of high-temperature geothermal reservoirs, and potentially exploitable supercritical geothermal resources. ........................28

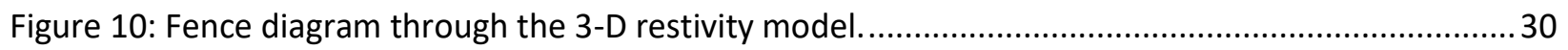

Figure 11: Profile through Rotokawa (RK) and Ohaaki $(\mathrm{OH})$ geothermal fields with earthquake

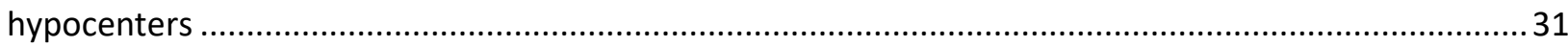

Figure 12: Plan-view slices through the MT resistivity model showing deep (D1, D2, D3 and D4) low-

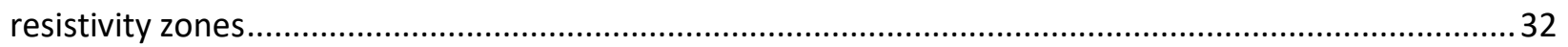

Figure 13: conceptual Model of an idealized TVZ geothermal system (Ratouis Zarrouk 2015) .................33

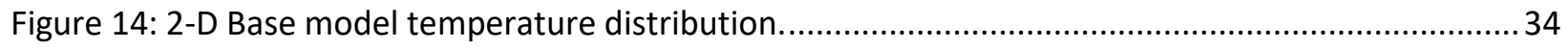

Figure 15: Model area (inside the blue lines), location of geothermal fields (red areas), ....................... 35

Figure 16: Temperature C distribution at a depth of 2950 mRSL for Model IV (E Kaya et al. 2014) ..........36

Figure 17: Model results, warm colors represent hotter near surface temperature .................................39

Figure 18: Aerial photo of the Rotokawa region that is included in the numerical model. ......................41

Figure 19: Natural state temperature isotherms $\left({ }^{\circ} \mathrm{C}\right)$ at $500 \mathrm{~m}, 1000 \mathrm{~m}, 1500 \mathrm{~m}$ and $2000 \mathrm{~m} \ldots \ldots \ldots \ldots \ldots \ldots . . . . . . .42$

Figure 20: Conceptual model that the Rotokawa system model is based............................................45

Figure 21:Interpreted natural state temperature in different areas of the Rotokawa reservoir...............46

Figure 22: Present-day seismic events in function of depth..............................................................48

Figure 23: Modified conceptual model of from Wilson, Rowland 2016 showing convection heat source

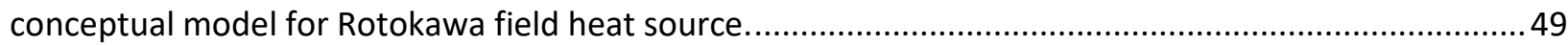

Figure 24: RK38 grid overlain -6500m MT resistivity from Bertrand et al. 2015....................................51

Figure 25: A vertical temperature slice of the RK38 model at $-6000 \mathrm{mRSL}$. The grid and Rotokawa well tracks shown in white. This is the bottom layer in the model a fixed temperature no flow boundary.....52 Figure 26: Fault process model grid of 1968 grid blocks. The grid is $18.5 \mathrm{~km}$ to $4.8 \mathrm{~km}$ ranging from $10 \mathrm{~m}$ to $780 \mathrm{~m}$ in the $\mathrm{x}$ direction and 10 to $950 \mathrm{~m}$ in the $\mathrm{y}$ direction.

Figure 27: Tornado plot of the single fault model at $-1000 \mathrm{~m}$ showing parameters impact on convection fluid temperature. 56

Figure 28: Tornado plot of the single fault model at $-1000 \mathrm{~m}$ showing parameters impact on up flow rate

Figure 29: Tornado plot of the single fault model at $-6000 \mathrm{~m}$ showing parameters impact on up flow rate across $-6000 \mathrm{mRSL}$.

Figure 30: Tornado plot of the single fault model at $-6000 \mathrm{~m}$ showing parameters impact on up flow rate. 
Figure 31: Single fault simulation varying permeabilities. Temperature and mass flow values are graphed as permeability increases logarithmically by a factor of 10 . 59

Figure 32: Single fault varying the permeability showing the relationship between the fault temperature and the up flowing fluid enthalpy.... 60

Figure 33: Single fault varying the permeability showing the relationship between the energy flow up and the mass flow up.

Figure 34: Single fault simulation ( $10 \mathrm{mD} x$ and $y$ ) varying the faults vertical permeabilities. Temperature and mass flow values are graphed as permeability increases logarithmically by a factor of 10 . 61 Figure 35: Single fault simulation ( $100 \mathrm{mD} x$ and $y)$ varying the faults vertical permeabilities. Temperature and mass flow values are graphed as permeability increases logarithmically by a factor of 10.

Figure 36: Single fault simulation ( $100 \mathrm{mD} x$ and $y$ ) varying the faults vertical permeabilities. Temperature and mass flow values are graphed as permeability increases logarithmically by a factor of 10.

Figure 37:Fault temperature and mass flow rate with simulated fault lengths. .....

Figure 38: Fault temperature and mass flow rate as the hot plate depth is varied.

Figure 39: Model RK38 natural state temperature and pressure match for the simulated temperatures are shown (points) shown alongside the published natural states temperatures for each region of the reservoir.

Figure 40:Model RK38 Temperature contour at -2000mRSL. Production and injection well tracks are also shown.

Figure 41:Model RK38 Temperature contours at $-1500,-2000,-2500$, and -3000 meters relative to sea level.

Figure 42:Model RK38 streamlines show direction of convection and are colored to show magnitude of the mass flow $(\mathrm{kg} / \mathrm{s})$..

Figure 43:Model RK38 streamlines mass flow labeled to show convection processes............................73

Figure 44: Model RK38 vertical Energy flow. Streamlines ..............................................................74

Figure 45: $-5000 \mathrm{mRSL}$ vertical permeability $\left(\mathrm{k}_{\mathrm{z}}\right)$ slice with 373,350 , and $330^{\circ} \mathrm{C}$ temperature contours. 77 Figure 46: RK38 373C contour showing extend of supercritical convection. A- 5500mRSL temperature slice is shown intercepting the temperature contour.

Figure 47: Thermophysical properties of supercritical water within pseudocritical range. (Gupta et al.

2010) 


\section{List of Tables}

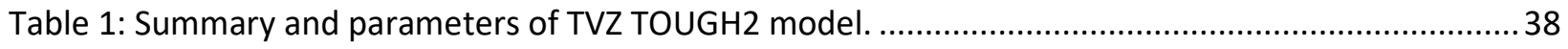

Table 2:Variables being tested for the single fault process model........................................................53

Table 3: Rock parameters for the single fault process model. ............................................................5

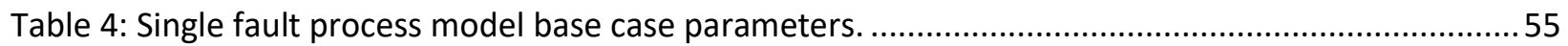

Table 5: General vertical zones of permeability in the Rotokawa geothermal system model...................69

Table 6: Vertical mass flow rate across $-3000 \mathrm{mRSL}$ layer showing the upflow into the base of the

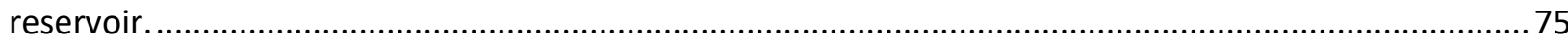

Table 7: Vertical mass flow rate across $-4000 \mathrm{mRSL}$ layer showing the upflow within the high temperature convection below the reservoir.

Table 8: Model RK38 showing similar upflow rate and upflow enthalpy for previous Rotokawa reservoir

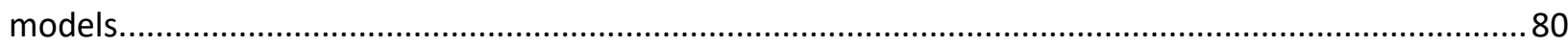




\section{Acknowledgements}

Thanks to my supervisors John Burnell and Mark McGuiness for sharing their time and knowledge with me. John put in significant time to get the supercritical convergence code to run without crashing. 


\section{Chapter 1: Introduction}

\section{Objective}

The objective of this thesis is to build a large scale TOUGH2 numerical model of the entire Rotokawa geothermal system model extending from the brittle ductile transition to surface. Simulating the natural state conditions of the Rotokawa geothermal system will give a better understanding of the nature of up flow into the Rotokawa geothermal reservoir. A review of all numerical modeling in the TVZ and the Rotokawa reservoir will be undertaken and a conceptual model of the Rotokawa geothermal reservoir and the larger geothermal system will be created. The conceptual model will then be converted into a numerical model and deterministically history matched to natural state temperature and pressure within the reservoir. Interpretations of this mode can them be made based off the results of the Numerical model. This model can then will be used to evaluate the feasibility of drilling a well into the modeled supercritical convection. Temperatures in this model will exceed supercritical conditions of water so a modified TOUGH2 code will be used to allow the super critical mass and heat balance iterations. The geothermal system model will be will different from a commercial geothermal reservoir model because the base will be a fixed temperature, no mass flow boundary.

\section{Overview of Geothermal Energy}

\section{Geothermal Systems and Power Generation}

A geothermal field is an area of geothermal activity is distinct and separate from neighboring areas of activity, A geothermal is system total subsurface hydrologic system associated with a geothermal field, encompassing the entire pathway of the fluid flow from rain water at the surface down too deep within the earth where it is heated and drove back to the surface by buoyance driven flow from the density differences of the hot fluid coming up and cooler meteoric water making its way down (Grant and Bixley, 2016). Heat can be transferred though conduction or convection, the latter being a more efficient method of transferring energy. The Heat flow from the deep within the earth to the surface and underground reservoirs that geothermal well tap into require and understanding of flow from the geothermal activity upwards. Volcanism is associated in almost all geothermal systems around the world as a higher temperature convective system demand additional heat above the normal conductive gradient.

A geothermal reservoir primary permeability is in fractured rock, with the reservoir extending a great distance vertical. Additionally, the vertical and lateral extend of the reservoir may not always be clear. A geothermal well is drilled as a conduit from the surface to into the high temperature geothermal reservoir to produce and extract energy from the heat of the geothermal fluid. A pressure differential from the hydrostatically pressured geothermal reservoir and the wellbore drives geothermal fluid into and up the wellbore. The geothermal fluid is separated at surface and flown into a geothermal power station to convert the heat energy of the geothermal fluid to electricity.

There are three types of geothermal power plants, a flash, binary or combined cycle plant. In a flash plant the geothermal fluid flows into a tank at surface that is a much lower pressure, causing some of the fluid to rapidly vaporize, or "flash" then separate the steam and brine. The vapor then drives a turbine, which drives a generator. If any liquid remains in the tank, it can be flashed again in a second and third tank to create additional steam for power generation. 
A binary cycle geothermal power generation plants differ from flash steam systems in that the water or steam from the geothermal reservoir never comes in contact with the turbine/generator units. Geothermal fluid and a secondary fluid with a much lower boiling point (typically pentane) than water pass through a heat exchanger. Heat from the geothermal fluid causes the secondary fluid to flash to vapor, which then drives the turbines and subsequently, the generators.

A combined cycle plant is incorporating both a flash and binary plant. The following a flash stage the steam is directed into a steam turbine while the brine can be directed to binary equipment. Additionally, steam exiting the turbine can still have sufficient energy to be used in a binary cycle.

Modern geothermal plants can require dozens of production and injection wells to maintain the fuel supply to the power plant. Brine and condensate are reinjected to maintain reservoir pressure, subsidence and mitigate reservoir cooling from marginal recharge allowing for decades of power generation. Periodically additional wells need to be drilled to maintain the station total mass flow, station enthalpy, maintain injection capacity, or explore additional zones of the reservoir. Production wells may be required in a geothermal field as a result of pressure decline, enthalpy decline, scaling, or casing damage. New injection wells may be drilled because of scaling, lack of reservoir pressure support from current wells, increased injection capacity due to field enthalpy decline or casing damage.

\section{Geothermal Energy in New Zealand}

Volcanism in New Zealand is a result of complex plate tectonic interactions between the Australian and Pacific Plates. The central Taupo Volcanic Zone (TVZ) in New Zealand is an area of intense magmatism associated with 23 high enthalpy geothermal systems extending from South of Lake Taupo to White Island and a product of the tectonic rifting-arc setting.

Geothermal has played an important role in New Zealand's electricity generation since the 1950s. New Zealand has roughly $10 \mathrm{GW}$ of total installed electrical generating capacity, $840.7 \mathrm{MW}$ of which is geothermal, generating 6345GWH for the year 2016. As of 2016 about 16.2 per cent of annual power generation is provided by thirteen geothermal stations, with additional direct heat being used in the paper and pulp, dairy, agriculture, and fishery industries (Sharp and Suomalainen, 2016).

Unlike other forms of renewable energy such as solar wind and hydro, geothermal is not drastically affected by externally environmental factors (e.g. drought, night, lack of wind), as a result plant power availability can be as high as $98 \%$. Worldwide there is $14,276 \mathrm{MW}$ of installed geothermal capacity as of May 2018 (Richter 2018).

Below the currently utilized New Zealand geothermal reservoirs, lie higher temperature unexplored resources that potentially present additional geothermal energy capacity. Since these zones lie below current reservoirs, they utilized by currently installed geothermal power generation facilities to maintain station enthalpy or increase the stations power generation. The potential supercritical geothermal reservoirs present numerous engineering problems such as corrosion, depth of drilling, zonal isolation and complex well completions but presents a vast currently un-utilized renewable energy resource.

\section{Rotokawa Geothermal Field}

Located in the Taupo Volcanic Zone, production in the Rotokawa geothermal field began in 1997 with a 27 MWe flash-binary power station, expanded to 34 MWe in 2006. In 2010, the installed capacity increased to $172 \mathrm{MW}$ with the commissioning of triple-flash condensing $138 \mathrm{MWe}$ Nga Awa Purua 
(Hernandez et. al 2015). To date, there are thirteen production wells supplying steam and brine to both power plants and five wells to reinject brine and condensate.

\section{Research Objectives}

The objective of this master's thesis research is to use geothermal numerical modeling to simulate the entire geothermal system from the brittle ductile transition to the surface to understand the fluid convection systems in Rotokawa and the TVZ. A modified version of TOUGH2 will allow for supercritical conditions to be simulated. The key objectives of this project will include the following.

- Create a conceptual model for the Rotokawa geothermal system.

- $\quad$ Create a fault process model to investigate the factors effecting the high temperature TVZ convection systems.

- Convert the conceptual model into a TOUGH2 numerical model of the Rotokawa geothermal system to match natural state temperatures of the Rotokawa geothermal reservoir.

- Analyse the numerical model to the Rotokawa geothermal system below Rotokawa depth and rock properties of potential supercritical reservoirs.

- Extrapolate the results to understand the permeability structure of high temperature geothermal systems in the TVZ and any potential viability of utilizing high supercritical geothermal systems in the TVZ.

Implications of this research can be used by geothermal operator or research geoscientists to get a better understanding the rock properties, permeabilities, and sizes of supercritical zones in the convection system below the Rotokawa geothermal reservoir.

\section{Chapter 2: Study Area}

\section{Tectonic Setting of New Zealand}

The evolution of the Taupo Volcanic zone is a result of a complex history of interaction between the pacific and Australian plates over the past 25- 30 Myr (Schellart et al., 2006; Mortimer et al., 2010; Schellart and Spakman,2012; Reyners, 2013; Timm et al., 2014). Under the north island the Pacific Plate subducts beneath the Australian plate, transitioning south-westwards into a strike slip zone of the alpine fault from 16Ma onwards (Wilson 2016). Under the South Island the Australian Plate Subducts beneath the pacific plate. As the oceanic plate subducts, it melts and wet rock ascends due to is lower density creating pressure in the mantle that causes volcanism and rifting. The rift zone creates faults that can enhance or hinder large deep fluid flow (Rowland and Summons, 2012). The current tectonic setting of the North Island can be seen in Figure 1 (Wilson and Rowland, 2016). 


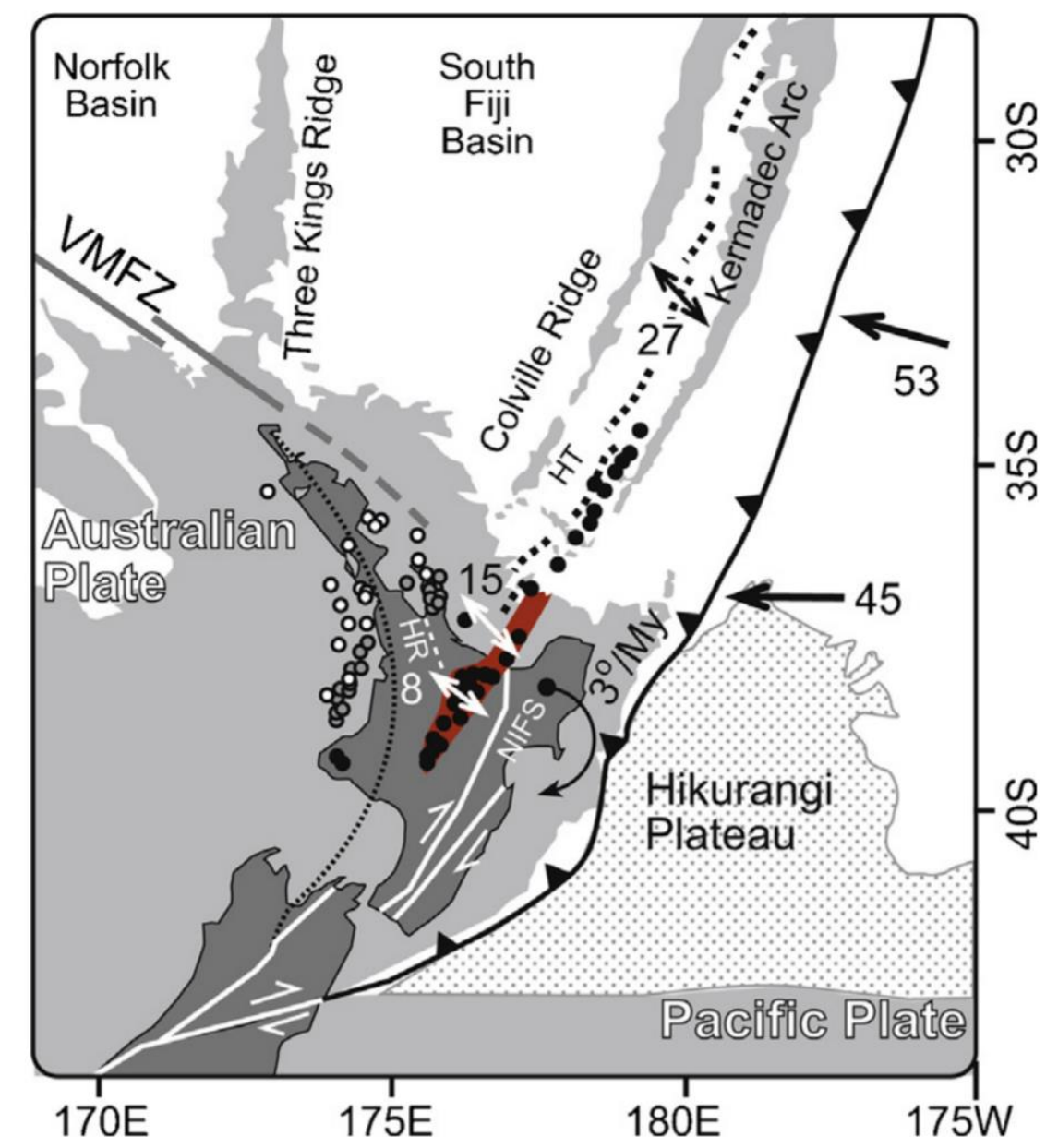

Figure 1: Current Tectonic setting of northern New Zealand. Annotated with volcanism for time periods. Current tectonic setting of northern New Zealand, annotated with loci of volcanism for three different time periods $\pm 0.5 \mathrm{Ma}$ (Circles: black $=0 \mathrm{Ma}$, grey $=8 \mathrm{MA}$, white $=16 \mathrm{Ma}$ ) from Seebeck et al. (2014a), vectors of extension (double arrows: Parson and Wright, 1996; Wallace et al., 2004) and relative plate motion (single arrows: DeMets et al., 1994) in mm/year. Rotation of eastern North Island shown for the period 3 Ma to present (Wallace et al., 2004). HR = Hauraki Rift; HT= Havre trough; NIFS = North Island Fault System; VMFZ = Veining Meinesz Fracture Zone (Wilson 2016)

The Veining Meinesz Fracture Zone (in Figure 1) is a complex WNW-striking transform and offsets that accommodated back arc opening north of New Zealand (Herzer and Mascle, 1996). As a result, a broad swathe of deformation parallel and oblique to this feature likely extend into continental northern New Zealand, (Herzer et al.,2009). The Hikurangi Plateau is an over-thickened piece of oceanic crust is subducting at the Hikurangi subduction margin. Hauraki Rift, is an active NNW-trending rift that extends more than $250 \mathrm{~km}$ from the northern Hauraki Gulf to an intersection with the TVZ. The North Island Fault System is a system of right-lateral faults located within Mesozoic metasedimentary basement rocks accommodating the margin parallel motion associated with oblique convergence at the plate boundary (Wilson and Rowland, 2016).

The Taupo Volcanic zone is an actively rifting arc widening at $15 \mathrm{~mm} / \mathrm{yr}$ in the NW into the Bay of Plenty and slowing to $7 \mathrm{~mm} / \mathrm{yr}$ to the south. This active rifting is known as the Taupo fault belt. It is characterized by extensive for intense volcanism and geothermal (shown in Figure 1). 
The geothermal process in New Zealand are a direct result of tectonic activity in the mid to upper crustal structure so understanding tectonic process that deform, fault, fracture and thin the ductile upper crust is crucial to the flow of fluid within the upper brittle zone of the curst (Wilson and Rowland, 2016). The Late Oligocene-to-present evolution of the plate boundary and which likely have impacts on the structure of the TVZ are shown as the red zone in Figure 1.

\section{The Taupo Volcanic Zone}

New Zealand has an abundant geothermal resource, with a potential median capacity equivalent to $3600 \mathrm{MW}$ of electrical generation. 25 geothermally active zones are located within the Taupo Volcanic Zone (TVZ) (Wilson and Rowland, 2016). The TVZ is an actively rifting, intra-arc basin associated with the Hikurangi subduction system, where the Pacific Plate subducts beneath the eastern side of the North Island (Cole and Spinks, 2009; Rowland and Simmons, 2012; Wilson et al., 1995). The rifting over the last $2 \mathrm{Myr}$ has produced over $6000 \mathrm{~km}^{3}$ of caldera-associated volcanic products and about four times as much magma is estimated to be trapped at depth below the central TVZ than has erupted, feeding heat, volatiles and chemicals into 25 geothermal systems. The central TVZ has a present-day average heat flow of $700 \mathrm{~mW} / \mathrm{m}^{2}$ and a total flux of $4.2 \mathrm{GW}$ (Bibby et al., 1995; Hochstein, 1995).

The TVZ is broken into 3 zones according to volcanic properties. The northern TVZ is stretches from Kawerau area north out beyond White Island to the edge of the continental shelf. It is characterized by arc volcanism and is primarily expressed by andesite-dacite composite cones. Aside from white island there are low levels of geothermal activity. Magma eruption rates are lower than central and southern TVZ.

The central Taupo volcanic zone is most hydrothermally active and associated with rhyolitic volcanism, stretching from Kawerau, to the southern end of Lake Taupo. Characterized by silicic volcanism and magmatism with associated geothermal activity and rift-related faulting. The Rotokawa geothermal field is located in the central TVZ and is labeled as number 20 in Figure 2.

The Southern TVZ is extends from the Pihanga-Kakarmea chain of composite cones southwest to Ruapehu. This zone is characterized by large composite cones mostly andesite -dacite composition, with little basalt and no rhyolite. This zone is more typical of what would be seen in typical continental arc. 
The eruption rate is one third of the central zone, and the hydrothermal output is one fifth (Wilson 2016).

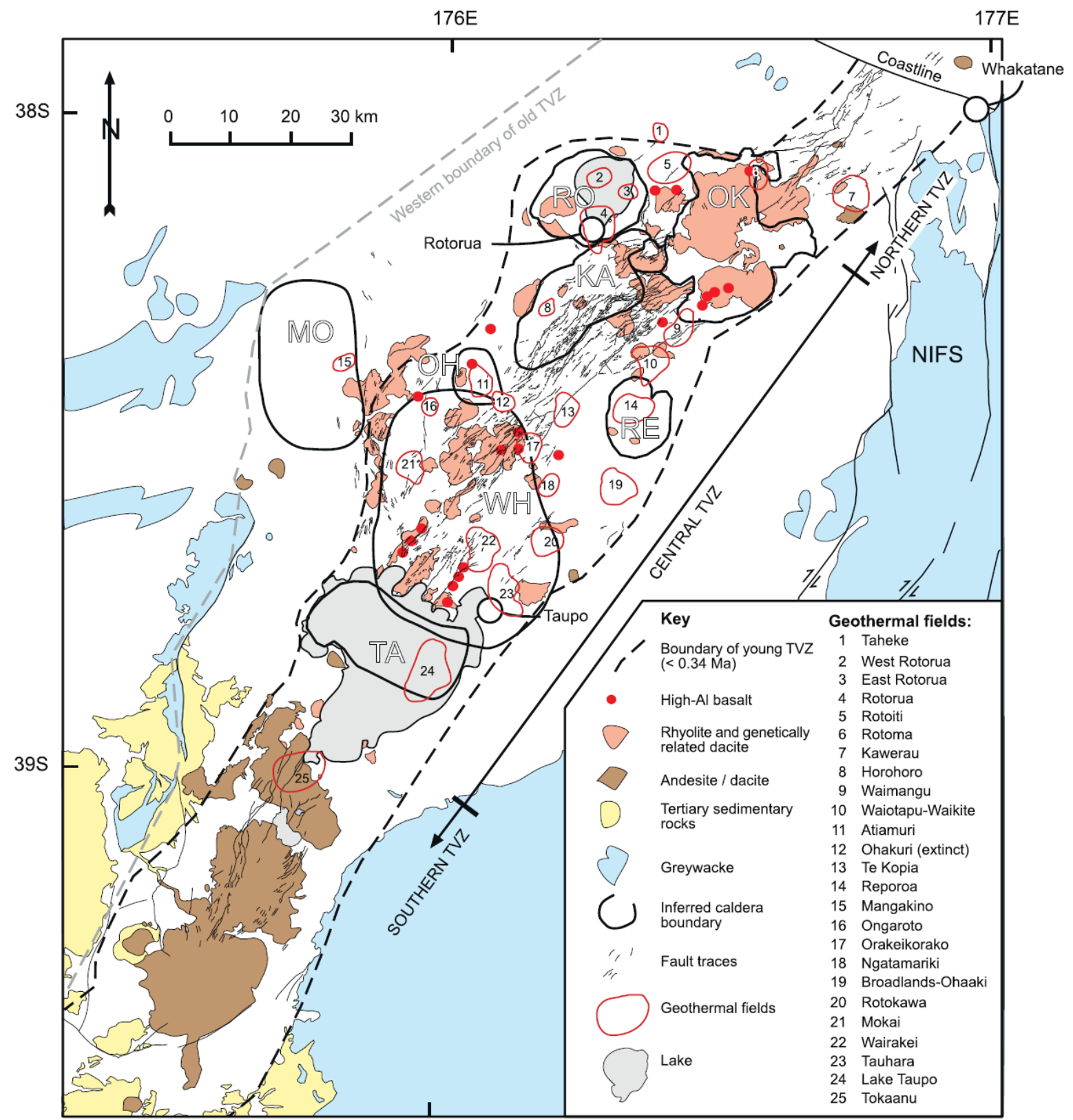

Figure 2: Geology of the TVZ showing major units (after Grindley, 1960; Healy et al., 1964; Leonard et al., 2010). White regions represent rock types other than those indicated (i.e., volcaniclastic rocks, lake sediments, reworked materials). Caldera boundaries are after Nairn et al. (1994), Gravley et al. (2007): KA - Kapenga, MO - Mangakino, OH-Ohakuri, OK - Okataina, RE - Reporoa, RO-Rotorua, TA - Taupo, WH - Whakamaru. Boundaries of the TVZ are modified after Wilson et al. (1995) and Villamor and Berryman (2001, 2006b). The young TVZ boundary is a composite of that defined on volcanic grounds (Wilson et al., 1995) and that defined on structural grounds (Villamorand Berryman, 2001, 2006b). NIFS = North Island Fault System. Lowresistivity zones were used to delimit the geothermal fields (after Bibby et al., 1995). Major towns labelled. Figure from Wilson and Rowland 2016. 
The correlation with TVZ geothermal fields and being either in a caldera or on the caldera boundary also cannot be ignored. Calderas and geothermal fields occupy $45 \%$ and $8 \%$ of the area of the TVZ respectively so some spatial overlap by chance can be expected (Bertrand et al., 2015). However, for this correlation to be meaningful, geothermal activity should occur in a systematic volcanic or structural association with calderas. Mere co-location is insufficient evidence for a genetic connection. Significant associations that caldera will have include a) intracaldera lava dome complexes which may overlie magma and have a permeable volcanic substructure, b) extensional fault zones crossing resurgent structural domes (not known in the TVZ), c) caldera ring faults that penetrate deep into the zone of magma accumulation and may be the loci for intrusions, d) caldera margins where listric collapse faults, megabreccias and pumiceous tuffs provide good permeability, and e) the intersections of tectonic or volcanic lineations with caldera structures (Wilson and Rowland 2016).

\section{Permeability Structure of the TVZ}

The development of geothermal fields within the Taupo volcanic zone develops as a result of regional hydrology, topography, faulting, geology and heat flow. Although the TVZ had a very large surface heat output the temperature gradients measured in drill-holes in this area were very low or even negative. Geothermal field are narrow zones of upflow zones of convectively circulated meteoric water systems (Hochstein, 1995). The geothermal reservoir is the high temperature and permeable zone in the earth that hot fluid can be extracted from. Heat flow at the surface is not always linked to a geothermal reservoir below the surface. However, fumarole, geysers, and hot springs along with other surface features are a result of a fault giving a permeable zone for superheated fluids to travel.

Fluid flow in most geothermal reservoirs is predominately through fractured and faulted rock. Most geothermal areas are associated with volcanic activity and are typically hosted with igneous or high compacted sedimentary rock with extremely low matrix permeability in some cases nanodarcy permeabilities. Intersections of the major geophysical trends with the active faults of the Taupo Rift are invoked to produced rift segmentation, and thus accommodation zones that favor permeability and geothermal activity (Rowland \& Simmons, 2012).

Normal faults of the Taupo Rift accommodate predominantly NW-SE extension of 12 mm/yr in the central North Island of New Zealand (Villamor \& Berryman, 2001; Wallace et al., 2004; Lamarche et al., 2006; Seebeck et al., 2014a). Normal faulting is thought to have initiated 1-2 Myr ago (Wilson et al., 1995) resulting in total crustal extension estimated at between 20 and $80 \%$ (Davey et al., 1995; Stratford \& Stern, 2006; Nicol et al., 2007). Outside of rhyolitic zones of Taupo and Okataina rifting is thought to be of tectonic origin (Robinson et al., 2009; Rowland et al., 2010; Villamor et al., 2011).

The bulk permeability of upper crustal rocks in the Taupo Rift, central North Island, New Zealand is a function of the development and intersection of active and inherited faults, caldera collapse structure. and/or lithology. The three major fault trends are 1) $30-45^{\circ}$ the dominate rift trend north of Lake Taupo; 2) $50-65^{\circ}$, the dominate riff trend north of the Ngakuru Graben; 3) $355-5^{\circ}$ inherited basement trends that may influence caldera collapse structures; and 4) $330^{\circ}$, approximately parallel to the structural trends within the basement and Hauraki Rift (Villamor et al., 2017). Faults also play an important role in crustal permeability as these faults are found within basement rocks. This trend is supported by geologic mapping geophysical imaging and borehole analysis (Villamor et al., 2017). 
All samples of both Toreless and Waipapa-type greywacke tested in Mielke et al., 2016, had permeability less a than $1 \mathrm{E}-16 \mathrm{~m}^{2}$ having relatively low porosity ranging from $1 \%-3 \%$. This is significant because at permeabilities this low the flow will be predominantly within the fracture network. Therefore understanding the orientation and patterns of fault and fracture, spacing, distribution and properties is essential for understanding fluid flow within the deep zones of the Taupo Volcanic Zone $(3 \mathrm{~km}+)$ and in the greywacke.

Caldera collapse can reach quite deep into the crust and is interpreted to 'stop' at the brittle-ductile transition (Cole et al., 2005). Although the collapse itself may be contained within 3-4 km depth, the underlying source mush will extend deeper and be strongly decompressed and degassed following the eruptions (e.g. Barker et al., 2015).

One aspect that is generally neglected in the literature is the impact that a caldera collapse has on the regional stress states, the depth to the brittle-ductile transition, the pressure and temperature gradients of the crust, and the regional hydrogeology. Intense disruptions to all of these physical factors are, however, expected to happen not only during caldera formation but also for some time afterwards. As discussed above, caldera structures are likely to be genetically linked to basement or crustal discontinuities (Chamberfort et al., 2017).

Geothermal fields of the TVZ have a high correlation with complex fault and fracture interactions. Appendix C.1.1. summarizes the different fault and fracture trends found in several geothermal fields in the Taupo Rift, the figure reproduced from Villamor et al., 2017. 


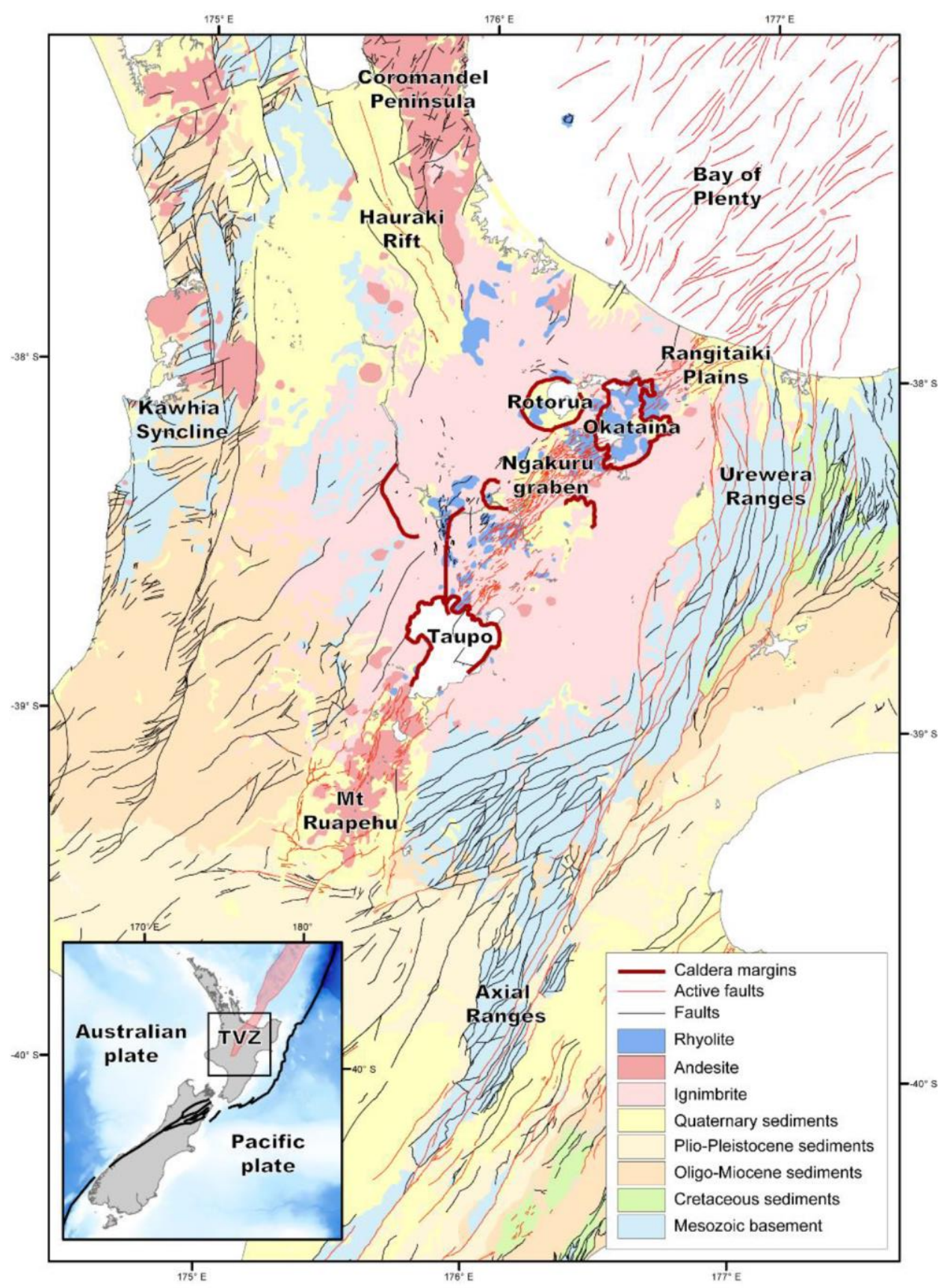

Figure 3: Structural elements of the Taupo Rift. Geology modified from Edbrooke et al., 2015. Figure from Villamor et. al, 2017.

While most geothermal fields result from a complex fault sometimes areas of complex fault interaction also result in no up-welling of hot fluid. They occur in higher density to the north-east of the rift trend. These zones in the Ngakuru graben have a higher density of faulting as can be seen in Figure 3 . In these highly faulted areas, inferred high crustal permeability most likely facilitates the down-welling of cold ground waters providing recharge to the up-welling geothermal plumes (Villamor et al., 2017).

Caldera faults represent a very different crustal weakness to the major basement terranes boundaries mentioned previously. Caldera faults will only affect the crust to depths above the location of the emptied magma chamber $\sim 5 \mathrm{~km}$ (Smith et al., 2005). Caldera boundaries are another major It is 
important to note that we have used the caldera boundaries delineated mainly with surface geology evidence (e.g., Leonard et al., 2010). However, geophysical data suggests that there could be more calderas currently buried under thick volcanic deposits (Bertrand et al., 2015).

Catastrophic caldera-forming events, such as the 25.4 ka Oruanui eruption at Taupo, are expected to produce extreme stress changes and modification of the hydrology and fault structure of any nearby hydrothermal systems. Indeed, such events have implications for the entire central TVZ, with permeabilities in the upper few kilometers of crust likely to change drastically, thus affecting heat and mass flow. Despite these impacts, it is apparent that many geothermal systems have been rejuvenated in the same location, with minimal long-term consequences from caldera-forming volcanic events (Wairakei-Tauhara, Rotokawa, Ngatamariki, Ohaaki, and Kawerau). While fluid chemistry, fracture/lithology-controlled permeability, and reservoir characteristics (fluid flow, feed zones, and outflow) may have changed, the location of the deep fluid and/or heat source is relatively stationary.

\section{Hydrothermal Convection within TVZ}

The source of the fluids in the TVZ has been debated since the industrial development of the region but the scientific community agrees that the dominant source of water in these systems is meteoric in origin with 6 to 20\% from magmatic-derived waters (Giggenbach, 1995).

Shallow intrusions are not an infinite heat source however as cooling happens quite rapidly, typically of the order of $\sim 20 \mathrm{kyr}$, mainly due to meteoric water circulation (Schöpa et al., 2017). The timing and longevity of the TVZ geothermal systems require a long-lasting magmatic heat supply that is repeatedly focused in the same geographical area. It is uncertain whether systems wane or die between episodes of vigorous activity, but most importantly the location of some hydrothermal systems has been consistent for over half a million years (e.g. Chambefort et al., 2014).

What controls the location and the deep heat source of the geothermal systems is thus likely to be linked to structures or pathways beneath the brittle crust. This inference is in agreement with recent structural investigations (Villamor et al., 2017), which show that while many active systems are located at fault intersections, not all intersections are favored by hot plumes, implying that deep permeable structures are necessary. It is hypothesized that deep, long lasting, crustal cross-arc discontinuities (occurring to accommodate the oblique extension and caldera volcano processes) favor permeability in the ductile crust. Several features might control these deep discontinuities: 1) the position and orientation of deeply buried caldera margins or magmatic systems; 2 ) inherited basement structure; 3 ) magmatism - deep-seated mush versus shallow melt-rich intrusions; and 4) arc-scale processes. (Chambefort et al., 2017) 


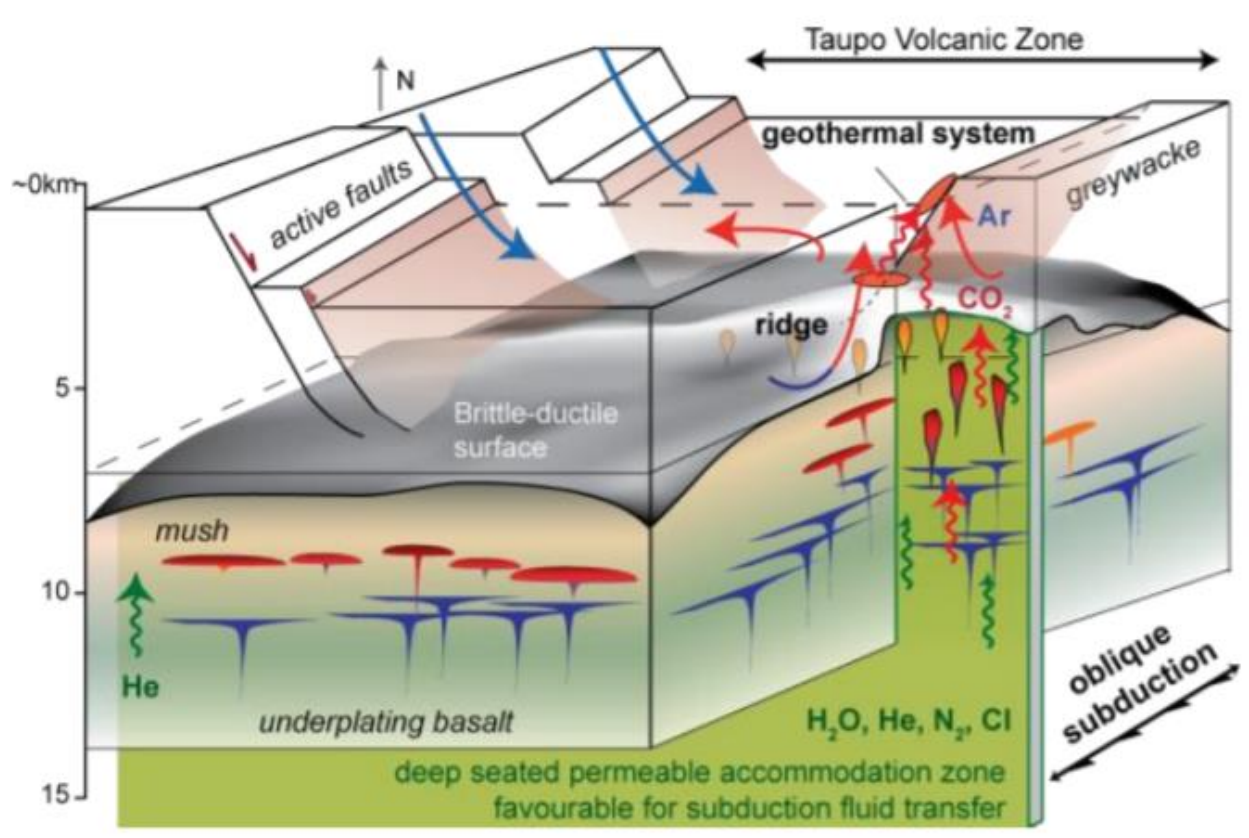

Figure 4: Conceptual model of the deep controls on high enthalpy New Zealand geothermal systems. (et.al, Chambefort 2017)

These discontinuities enable vertical mass transport of melts and volatiles, locally enhancing crustal melting and creating ridges on the surface representing the brittle-ductile transition. These ridges create loci for the roots of groundwater convective cells. The presence of these ridges could explain the apparent persistence of the geothermal systems, despite interruption in some cases by caldera collapse or active faulting, and the variability of geothermal fluid chemistry and magma compositions (et.al, Chambefort 2017).

Downward recharge of cool meteoric water is enhanced by the abundant faulting of the Taupo Rift as suggested by Villamor et al., (2017). These waters, once heated, react with the volcanic sequence and greywacke basement rocks resulting in an enrichment in sulfur and chlorine (as suggested by Mountain et al., 2017). Simultaneously, deep-derived $\mathrm{CO}_{2}$ and unreactive gases migrate upwards from the subduction slab and the deep crust via long lasting discontinuities. Passage of these gases in association with melts may influence the volume and composition of crustal magmatism. Rising hot $\mathrm{CO}_{2}$ from the deep mush zone will encounter circulating groundwater at or above the brittle ductile transition creating a hot plume of two-phase up flow dilute fluid. The intersection of the oblique discontinuities with the eastern edge of the TVZ and less permeable Torlesse greywacke (Wood et al., 2001) may force the fluid upwards, thus explaining the persistent location of the geothermal systems see Figure 4 (Chambefort et al., 2017).

There is a little uncertainty as to what temperature the BDT occurs in the TVZ. As stated by Bürgmann and Dresen, 2008; Crustal seismicity is limited to temperatures between $250-450{ }^{\circ} \mathrm{C}$ They suggest that in continental rocks the brittle-ductile transition occurs within the temperature range $300-500{ }^{\circ} \mathrm{C}$ with geothermal drilling results that indicate the transition occurs at $370-400{ }^{\circ} \mathrm{C}$ (Fournier, 1999). At the brittle ductile transition, the pore pressure will transition from hydrostatic to lithostatic pressure and fractures will heal. Heat transport will then become convective or advective in a depth interval that may be as small as a few hundred meters (Weis et al., 2012). 


\section{Rotokawa Geothermal System}

The Rotokawa geothermal system itself has been suggested to be up to 20,000 years old based on knowledge of timing of hydrothermal eruptions (Krupp and Seward, 1987; Vucetich and Howorth, 1976). The Rotokawa geothermal field is an important New Zealand resource as it is one of seven geothermal fields utilized for power generation (174 MWe capacity) (Hernandez et al., 2015). The field occupies $\sim 28 \mathrm{~km}^{2}$, as defined by shallow resistivity mapping (Risk, 2000). Although the Rotokawa geothermal systems is young other hydrothermal systems in the TVZ.

Rotokawa is a high temperature liquid dominated geothermal in the central part of the TVZ. Natural state fluid temperature within the deep Rotokawa reservoir can be up to $\sim 340$ $\mathrm{C}$ (Hedenquist et al., 1988; Winick et al., 2011). The field was identified from surface thermal features as well as a Schlumberger resistivity survey. Low resistivity, high smectite, geothermally altered clays are often indications of geothermal activity in the TVZ.

\section{Rotokawa Geology}

A number of geothermal surface features are present on the surface above Rotokawa. This includes, hot springs, seeps, a fumarole, several areas of steaming ground and hydrothermal eruption craters. Lake Rotokawa is a large acid-sulphate $(\mathrm{pH} \sim 2)$ feature which is likely a hydrothermal eruption crater (Browne and Lawless, 2001).

\section{Stratigraphy}

Schlumberger resistivity surveys were first undertaken at Rotokawa in the 1960s, and these surveys provided shallow (above $\sim 500 \mathrm{~m}$ depth) apparent resistivities. Correlation of these zones of low resistivity/high smectite clay content to natural state well temperature profiles, show they are related to low permeability, indicated by linear, or conductive, temperature profiles (Figure 5). These zones of high smectite clay content represent altered rocks in the Rotokawa Geothermal Field that form low permeability caps for aquifers. Lowest resistivity values occur within the upper $300 \mathrm{~m}$ of the field. These zones corresponding to high smectite clay within the Huka Falls Formation and Parariki Breccia and act as a shallow aquifer cap. Resistivity increases below this cap, associated with decreasing smectite clay content within the Haparangi Rhyolite lava and Waiora Formation, the geological units which form the intermediate aquifer.

Drill cuttings and cores from wells drilled into the Rotokawa geothermal reservoir from $500 \mathrm{~m}$ to $3065 \mathrm{~m}$ provide information on subsurface stratigraphy (Winick et al., 2011). Basement rock within the Rotokawa geothermal field is composed of Late-Paleozoic to Late-Mesozoic, fine, silty, greywacke sandstone and argillite rocks (Grindleyet al., 1985; Rae, 2007; Wallis et al., 2013). Basement greywacke has been encountered by injection wells RK19-24 and in the bottom of production well RK16. A fluid flow test done across a sample of Torlesse greywacke at a confining pressure of $20 \mathrm{MPa}$ provided a very low permeability value of $\sim 4.824 \times 10-22 \mathrm{~m} 2$ ( 4.89x10-7 mD). Both greywacke terranes have very low permeability and porosity confirming a dominant fracture control over fluid flow. Mielke et al., 2016, tested 150 cores. Samples from Waipapa-type and Torlesse-type greywacke exhibit minor rheological differences, with Waipapa-type greywacke having lowest porosity (about $1 \%$ vs. $3 \%$ ) and highest bulk thermal conductivity $\left(2.5 \mathrm{~W} \mathrm{~m}^{-1} \mathrm{~K}^{-1} \mathrm{vs} .1 .7 \mathrm{~W} \mathrm{~m}^{-1} \mathrm{~K}^{-1}\right)$ and specific heat capacity $\left(0.8 \mathrm{~kJ} \mathrm{~kg}^{-1} \mathrm{~K}^{-1} \mathrm{vs} .0 .7 \mathrm{~kJ}\right.$ $\mathrm{kg}^{-1} \mathrm{~K}^{-1}$ ). Matrix permeability is $1 \mathrm{E}-16 \mathrm{~m}^{2}$ for all greywacke samples.

This is overlain by the Rotokawa Andesite, a laterally extensive and complex sequence of andesite lava flows and breccias up to 2200m (Grindley et al., 1985; Rae, 2007; Rae et al., 2011; Wyering et al.,2014). 
Rotokawa Andesite complex is centered on the Rotokawa geothermal field, with initial andesitic volcanism would have involved magmas migrating through faults and fractures to the surface > 1.9 Ma, constructing a large volcano under Rotokawa (Anderson, 2011; Chambefort et al., 2014; Downs et al., 2014; Eastwood et al., 2013).

As stated by the most detailed and recent geological stratigraphy review "above the Rotokawa Andesite sequence lie the volcaniclastic and sedimentary deposits the Tahorakuri and Waikora Formations. In places, an andesite of limited extent Nga Awa Purua Andesite, and a stratigraphically younger ignimbrite the Wairakei ignimbrite (Browne et al., 1992; Gravley et al., 2006; Wallis et al.,2012; Wyering et al., 2014). The Waikora Formation is a rounded to sub-rounded pebble conglomerate (up to $250 \mathrm{~m}$ thick) that is largely comprised of eroded greywacke sandstone and argillite silt-stone deposited in a fluvial environment (Anderson, 2011; Rae,2007). The Tahorakuri Formation at the Rotokawa Geothermal Field consists of a white, crystal-vitric-lithic tuff, or ignimbrite of variable thickness (up to $250 \mathrm{~m}$ ), which can contain pumice fiamme, greywacke and andesite lithics, and minor sedimentary deposits (Anderson, 2011; Rae, 2007; Wyering et al., 2014). The Nga Awa Purua Andesite, an eruptive andesite unit originally grouped with the Rotokawa Andesite, (Wallis et al., 2013). The Wairakei Ignimbrite is part of the Whakamaru Group, a sequence of erupted ignimbrites of 330-340 ka (Wilson et al., 1986). The Wairakei ignimbrite are overlain by the volcano-sedimentary Waiora Formation intermixed with rhyolite lavas, breccias and domes of the Haparangi Rhyolite Group (Bowyer and Holt, 2010; Rae, 2007; Winick et al., 2011). he units of the Haparangi Rhyolite Group are reported to be anywhere between 450 and $800 \mathrm{~m}$ thick (Anderson, 2011; Grindley et al., 1985; Rae, 2007; Wallis et al.,2013), with thicker units occurring at shallower depths towards the north (Rae, 2007). In the Rotokawa Geothermal Field, the Waiora Formation consists interbedded layers of pumice, lithic (rhyolite, andesite, greywacke), crystal-rich (hornblende, quartz, plagioclase), vitric tuffs, ashes and breccias that can be up to $550 \mathrm{~m}$ thick (Anderson,2011; Rae, 2007). The Waiora Formation is overlain by locally derived Parariki hydrothermal eruption breccias (consisting of quartz-feldspar rich, tuffaceous breccia in a silty-clay matrix) and finely laminated mud-stones, siltstones, and pumiceous sandstone, lacustrine deposits of the Huka Falls Formation (Anderson, 2011; Wallis et al., 2013).Intercalation of the Parariki hydrothermal eruption breccias and Huka Falls Formation deposits occurs on the southern side of the Waikato River in the Rotokawa Geothermal Field (Rae, 2007). These units are in turn overlain by the 26-27 ka Oruanui Formation (20-50 m thick) comprised of pumice tuff containing rhyolite lava lithic clasts and quartz and feldspar crystals (Rae, 2007)

The shallow groundwater aquifer is hosted mainly within the Oruanui Formation and is underlain by the Parariki Breccia and Huka Falls Formation, which act as an impermeable aquitard (Winick et al., 2011). The intermediate aquifer, hosted mainly within the Waiora Formation and Haparangi Rhyolite, is a complex mixture of down-ward migrating fluids from the shallow groundwater system, boiled, deep reservoir fluids migrating upward through an area of weakly developed reservoir clay cap, steam condensates, and heated, marginal groundwater (Bowyer et al., 2008; Winick et al.,2011)". D.D. McNamara et al. (2016). All of the geologic units described can be seen in the geologic cross section in Figure 5. 


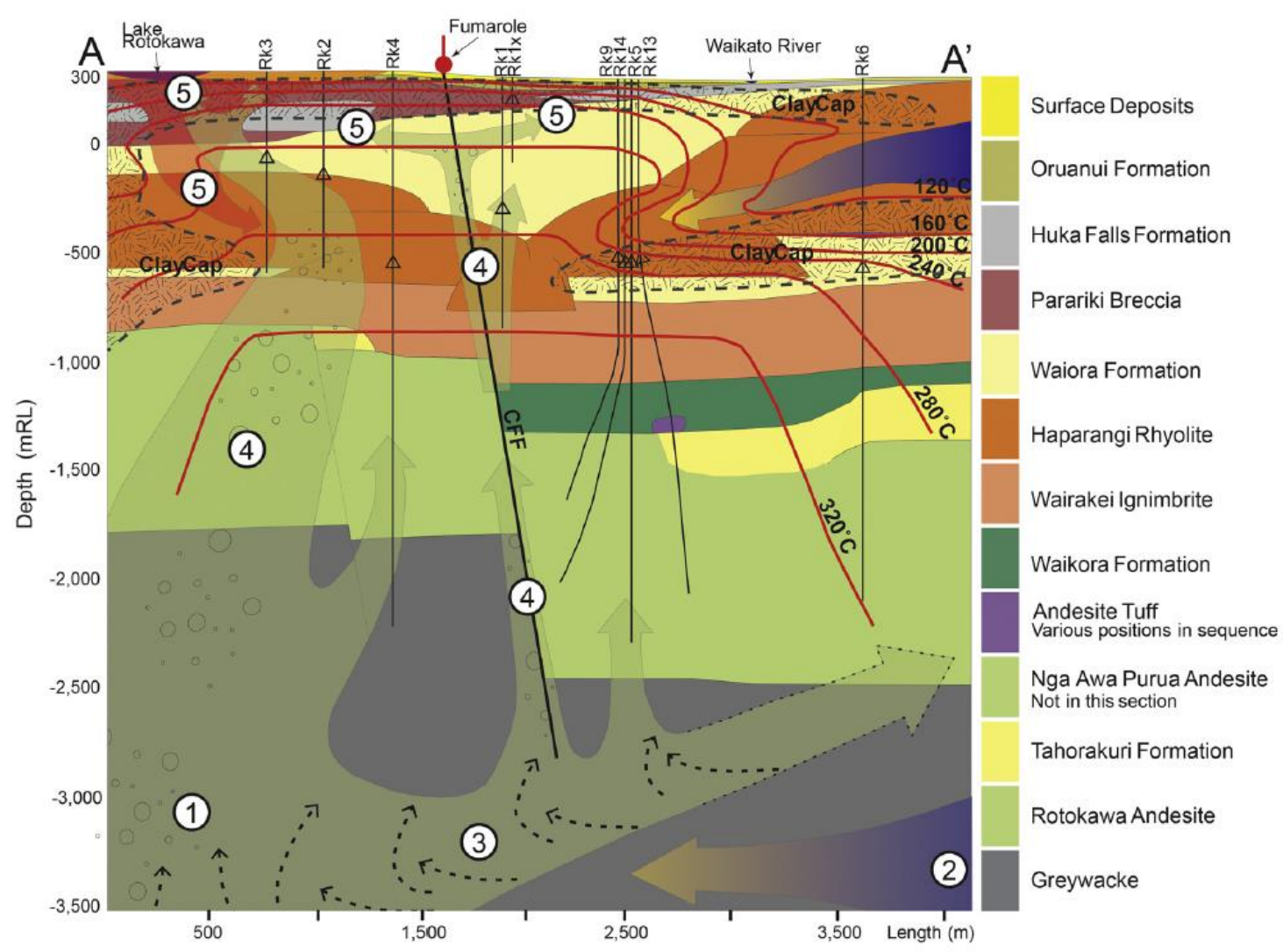

Figure 5:Cross-section of the Rotokawa Geothermal Field ( $A-A^{\prime}$ as shown in Figure 6) showing geological units, well locations $(R k 1, R k 1 x, R k 2, R k 3, R k 4, R k 5, R k 6, R k 9, R k 13, R k 14)$, clay cap, isotherms $\left(120^{\circ} \mathrm{C}, 160^{\circ} \mathrm{C}, 200^{\circ} \mathrm{C}, 240^{\circ} \mathrm{C}, 280^{\circ} \mathrm{C}, 320^{\circ} \mathrm{C}\right)$, the Central Field Fault, and geochemical processes in the reservoir ( 1 = hot two-phase upflow, $2=$ deep conductively heated groundwater (up to $\left.290^{\circ} \mathrm{C}\right), 3=$ dilution and mixing with the deep conductively heated groundwater, $4=$ adiabatic boiling, $5=$ steam heated ground water). Adapted from Winick et al. (2011). Image from D.D. McNamara et al. (2016)

\section{Structure}

The reservoir structure is a catch-all term for the brittle deformation of rock in response to stress. It is dominantly comprised of two groups of features: faults (places where brittle deformation has resulted in measurable offset in a rock unit) and fractures (brittle deformation without appreciable offset). Geothermal reservoirs are typically dominated by fault and fracture permeability as appose to matrix rock permeability. The relationship between structure, in particular large faults, and the geometry of a geothermal reservoir is complex and sometimes contradictory because as often as faults are agents of permeability enhancement, they may also reduce it (Wallis et al., 2017). The movement history (magnitude of rupture(s) and approximate timing), associated secondary mineralization, mechanical properties of the host rock, and any interplay with other nearby structures will all influence the nature of a structure's permeability (Rowland and Simmons, 2012). The relationship a structure has with the present and past tectonic regimes is also key because it dictates the initial rupture and reactivation, and therefore the likelihood a structure is still open to flow (Barton and Zoback, 1992; Barton et al., 1995).

Wells encounter basement greywacke and the andesite at different elevations, suggesting SW-NE striking faults as well as a NE-SW trending graben structure that provides the main permeability in the reservoir. Currently active microseicmic events caused by deep fluid reinjection starting in 2005 is 
dominated by location and rate of reinjection but bounded along the main reservoir fault. As a result, fault structure can have a significant impact on fluid flow in the reservoir and can be a either a conduit or barrier for fluid flow.

Permeable zones in the deep wells RK5, RK9, RK13-14, and RK 6-17 indicate that the geothermal reservoir is primarily within the Rotokawa Andesite, approximately $1-2.5 \mathrm{~km}$ below sea level. The andesite is underlain by greywacke basement rocks (Bowyer and Holt, 2010). RK17 is the only well to intersecting the interpreted fault and shows permeable zones occur on either side of the fault interaction suggesting that the reservoir permeability is affected by the fault. There are three NE-SW striking, normal faults that significantly offset the greywacke basement and Rotokawa Andesite, forming a narrow graben structure that widens to the NE. The graben is bounded to the NW by the SE dipping Production Field Fault (PFF) and to the SE by the NW dipping Central Field Fault (CFF). The PFF, CFF and Injection Field Fault (IFF) are thought to extended from the greywacke, basement, Rotokawa Andesite, and into the Wairakei Ignimbrite. The central field fault has significant offset greater than $400 \mathrm{~m}$. Offset at the Wairakei Ignimbrite is small indicate low activity since deposition (D.D. McNamara et al. ,2016) see Figure 6.

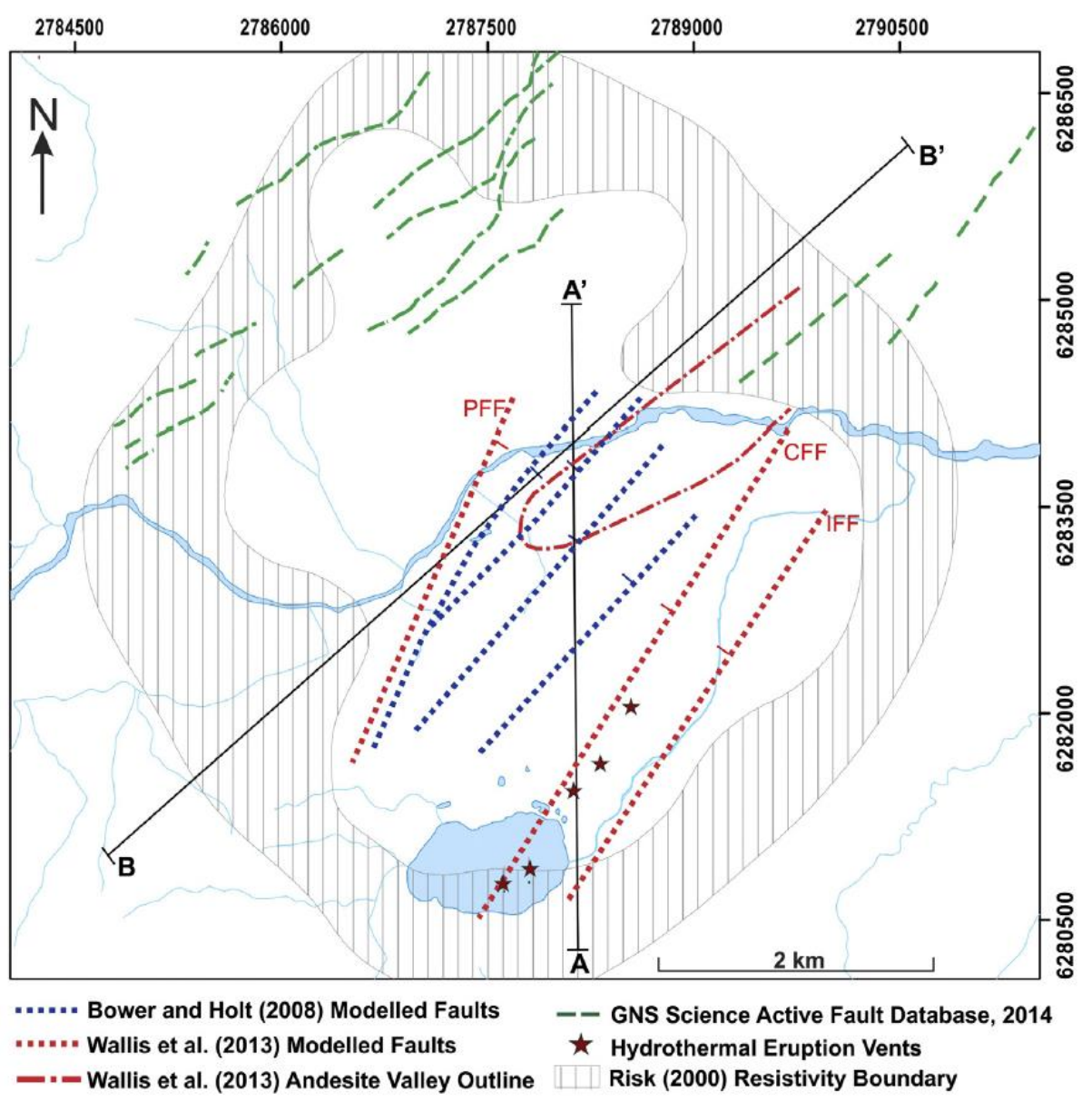

Figure 6: Map of the Rotokawa Geothermal Field showing active faults from GNS Active Fault Data Base (2014), modelled structures from Bowyer and Holt (2008), and modelled structures from Wallis et al. (2013). The Central Field fault (CFF), Production field fault (PFF) and Injection field fault (IFF) are the primary focus of modeling. 
Interpretation of structure and stress data from borehole image logs (collected mainly within the andesite units) show fracture orientations are dominated by NE-SW strikes with either NW or SE dip directions. Wells that have micro image logs have a predominant fracture dip direction thought to be influenced by their proximity to the larger fault structures. Fracture dip directions have alternating zones of SE and NW dipping fractures suggesting antithetic faulting in the graben. This is a feature typical of normal faulting environments.

\section{Rotokawa Geophysical interpretations.}

Numerous geophysical measurements can be made at the surface that can allow geoscientists to make observations that can be interpreted to indicate geologic and hydrological features within the earth. Geophysics, including studies of microseismicity, magnetotellurics (MT), electrical resistivity, gravity surveys, magnetic anomalies, and self-potential surveys, has been utilized extensively at Rotokawa for early exploration drilling through to field development and operations (Bannister et al., 2008, 2010; Bertrand et al.,2012; Bibby et al., 2005; Heise et al., 2008; Hochstein et al., 1990; Hunt and Harms, 1990; Hunt and Bowyer, 2007; Rawlinson, 2011; Risk, 2000; Sewell et al., 2013a, 2015; Sherburn et al., 2013, 2015; Soengkono et al., 1991).

Magnetotellurics is an electromagnetic geophysical method for inferring the earth's subsurface electrical conductivity from measurements of natural geomagnetic and geoelectric field variation at the Earth's surface. Schlumberger resistivity surveys were first undertaken at Rotokawa in the 1960s and used to assist well placement (Risk, 2000), followed by a higher resolution MT survey in 2004 to help well placement of deep injectors. Low resistivity at Rotokawa correlates well with higher smectite clay levels ( $~ 5-30 \%)$ as determined from methylene blue tests of drill-cuttings, as is observed in most hightemperature, volcanic geothermal fields (Cumming, 2009; Gunderson et al., 2000; Ussher et al., 2000). Clay have low permeabilities blocking fluid convection resulting in conductive temperature profiles. These low resistivity indicators typically occur in the upper $300 \mathrm{~m}$ of stratigraphy and have historically been used as an indicator for geothermal fields in the TVZ (Risk, 2000). At Rotokawa the high smectite clay abundances are within the Huka Falls Formation and Parariki Breccia acting as the cap rock for the formation. Resistivity increases below this cap, associated with decreasing smectite clay content within the Haparangi Rhyolite lava and Waiora Formation, the geological units which form the intermediate aquifer (D.D. McNamara et al. 2016).

Higher resistivities persist to depth $(\sim 2-3 \mathrm{~km})$ within the center of the field, associated with higher rank clay alteration (illite and chlorite) and near boiling-point-for-depth temperatures in an area found between wells RK1, RK2, RK3, RK4, and RK11. A deeper ( 800-1200 m depth), low resistivity layer is observed at the margins of the field which is associated with low permeability, smectite-altered rock overlying the deep reservoir. The lateral transition from higher resistivity to lower resistivity at these depths appears to be associated with a lateral transition from the permeable, high temperature, convecting reservoir to lower temperature and lower bulk permeability where heat transfer is dominantly conductive (e.g. 330-340 $\mathrm{C}$ and high permeability measured in well RK24 and $\sim 200 \cdot \mathrm{C}$ and low permeability measured in well RK19), Bertrand et al., 2012. 


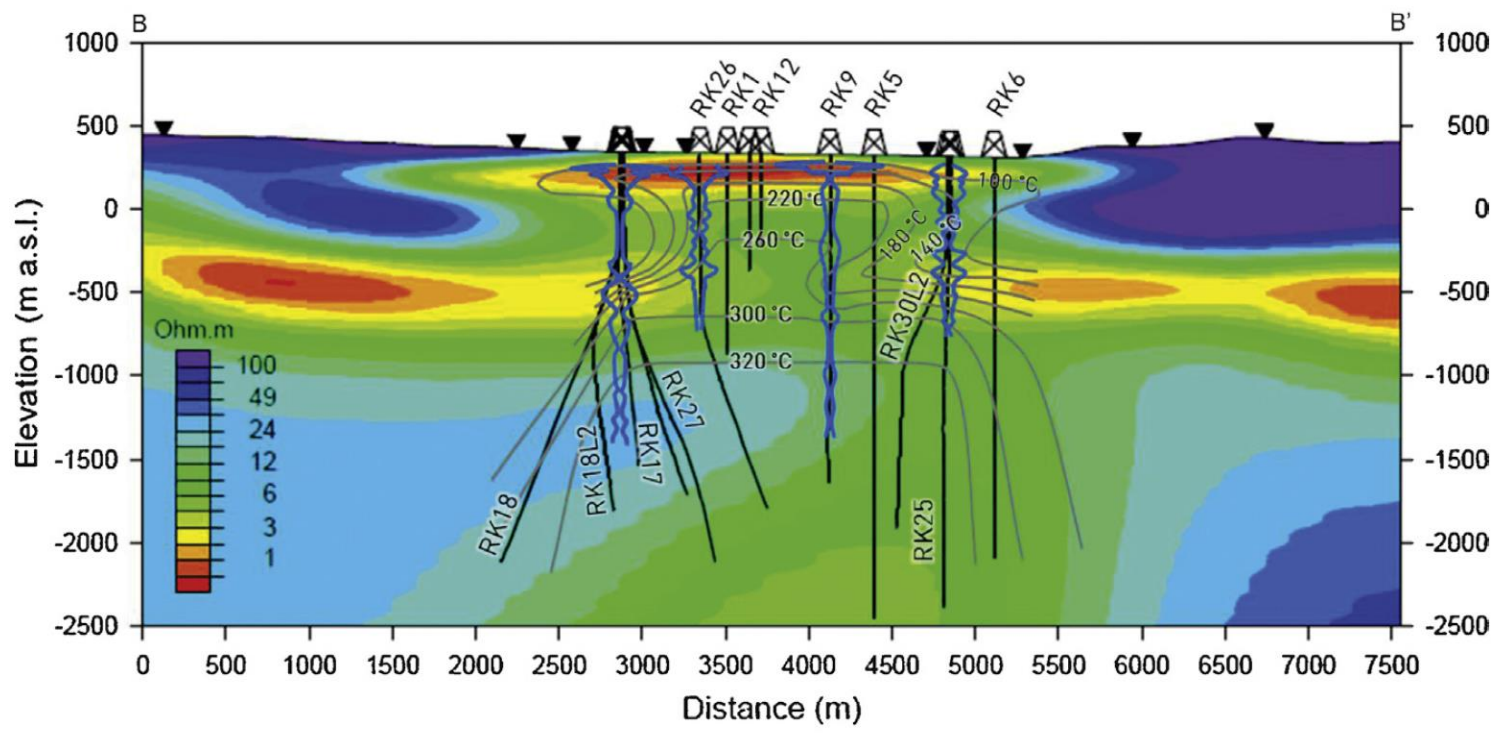

Figure 7: SW-NE MT cross-section (B-Bas shown in Fig. 3). Grey lines represent isotherms, black lines represent well tracks, and blue lines either side of well tracks are smectite logs. Modified from Sewell et al., 2012; the figure is from D.D. McNamara et al., 2016.

When injecting fluid into a geothermal reservoir, pore fluid pressure is significantly increase, this decreases the normal stress closing faults lowering the shear stress need for failure. Additionally, the rock is cooled resulting in contraction. Both these factors create seismicity (typically $<3.5$ magnitude) where injection fluid travels. The passive monitoring of this induced seismicity is known as microseicmic monitoring, and has proven to be a valuable reservoir monitoring tool at Rotokawa (Bannister et al., 2008; Rawlinson, 2011; Sewell et al., 2013a; Sherburn et al., 2013). A network of 10 surface seismometers has operated almost continuously at Rotokawa since 2008. The microseismicity is mostly located close to injection wells with magnitudes below 3.5, similar to other geothermal fields worldwide (e.g. Majer et al., 2007). Following deep injection to the south east of the field in 2008, almost all of the microseismicity has occurred within a rectangle between deep injection well and production wells 
A.

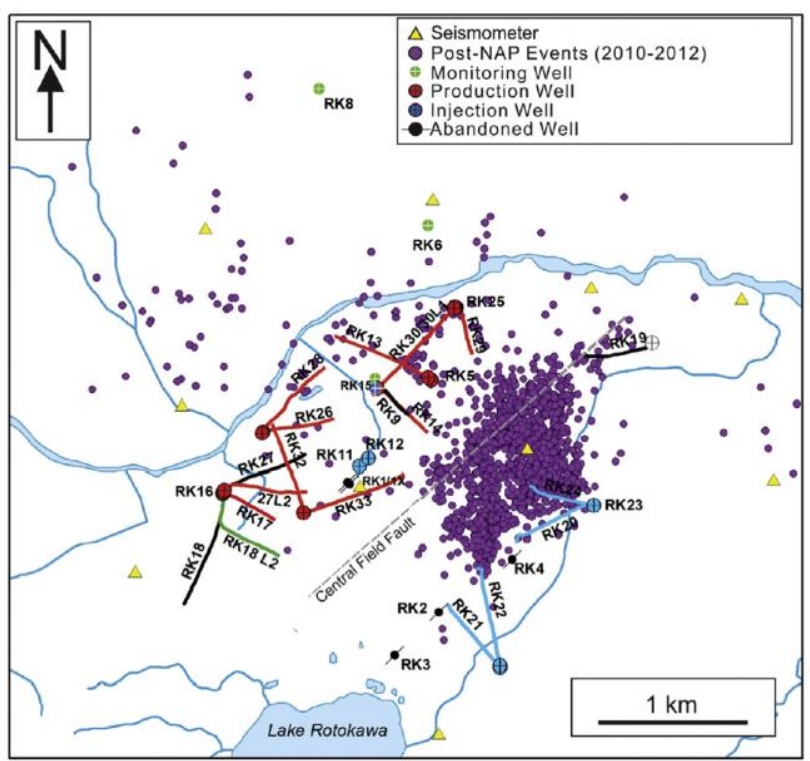

B.

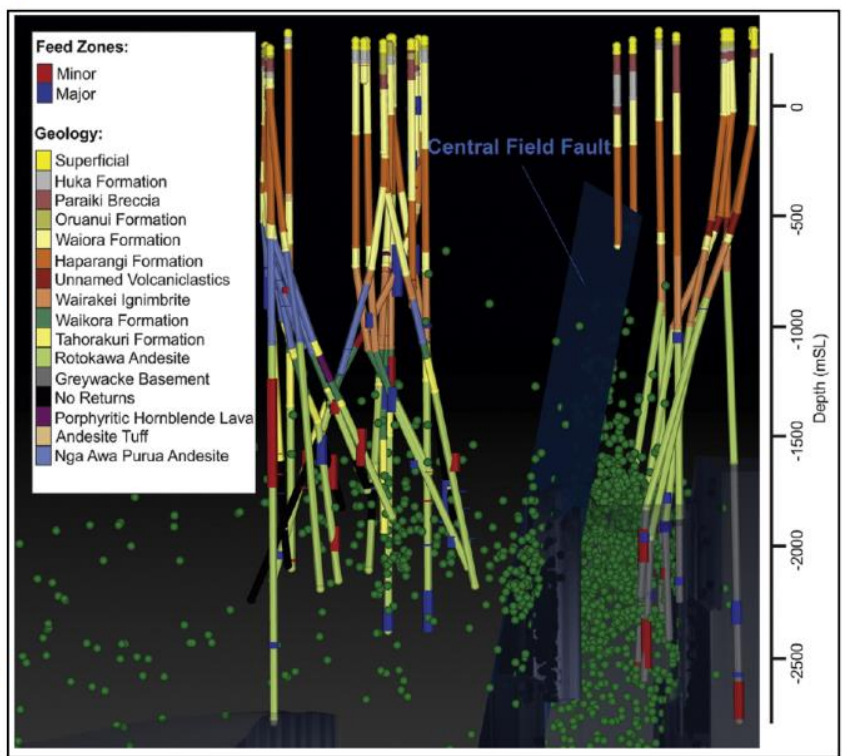

Figure 8: A. MEQ events shown in relation to wells. Most located between injection and production wells. B. MEQ events shown in relation to formation tops, events are clustered around to the injection side of the CFF (Sewell et. al 2015)

Permeable zones that account for most of the flow in the deep injection wells range from $-1500 \mathrm{~m}$ to $-3000 \mathrm{~m}$ elevation. Most MEQs also occur in the range of $-1500 \mathrm{~m}$ to $-3000 \mathrm{~m}$ elevation with relatively few events occurring below $-3000 \mathrm{~m}$ and only a few occurring below $-3500 \mathrm{~m}$ (Figure 8). Using the interpretation that the majority of the MEQs are triggered by thermal stresses due to cooling, it is therefore inferred that most of the injected fluid does not sink to great depth below the injection feed zones. This implies either, that vertical permeability is generally low below the injection zones within the injection area or the injection fluid is re-heated to the reservoir temperature. In either case, the base of the MEQ activity is indicating the 'effective' base of the reservoir (i.e. the base of the volume of rock that is being cooled by injection). Although the MEQs do not appear to extend much below injection points, there is significant uncertainty in the depth estimates for these events. Depth uncertainty is estimated to be $+/-500 \mathrm{~m}$, due mostly to uncertainty in the velocity model used to locate the earthquakes (Sherburn et al., 2013). Velocity above $1000 \mathrm{~m}$ is particularly uncertain as it is poorly resolved by tomography, the current basis of the velocity model at Rotokawa. Performing a check-shot survey to directly measure velocities shallower than $1000 \mathrm{~m}$ depth would significantly reduce this uncertainty. Based mostly on the observation that the MEQs do not appear to extend below injection points, whilst taking into account likely uncertainty in depth, the permeability in the Rotokawa numerical model has been lowered between $-3000 \mathrm{~m}$ and $-4000 \mathrm{~m}$ elevation (Hernandez et al., 2015). (Sewell et al. 2015). Additional MEQ events can be seen in appendix C.1.2.

Microseicmic monitoring has usefully constrained the pattern of injection flow at Rotokawa and characterized a major structure that likely influences reservoir hydrology. Detailed correlation of the MEQs with operational data (production/injection locations and flows) over time has been important to the interpretation. This was supported by further conceptual integration with other geoscience datasets, particularly the geology, geochemistry, natural state temperatures, and MT resistivity. The permeability pattern inferred from the MEQs has been integrated into the conceptual and numerical models of the Rotokawa reservoir. A major NE-SW trending structure, the Central Field Fault (CFF), bounds the 
extension of the MEQs from the injection to the production area, and appears to act as a barrier to flow across its strike in a manner consistent with initial tracer observations, Sewell et al., 2015. Swarm-like activity (>10-15 events per day) also appears to occur along the CFF and may be triggered by field-wide pressure transients associated with major changes in production and injection. Based on geology, thermodynamics and geochemistry, this fault also appears to be a zone of enhanced vertical permeability along its strike, at least at depths shallower than $1500 \mathrm{~m}$. The fault acting as a barrier across its strike and a conduit along the dip has been included in the reservoir conceptual and numerical models and has assisted with production well targeting and the field development strategy. The majority of MEQ activity occurs over the same depth range as the permeable zones in the injection wells $(-1500 \mathrm{~m}$ to $-3000 \mathrm{~m})$.

\section{Super Critical Geothermal Systems}

Super critical geothermal systems are very high temperature and pressure located at depths typically near the brittle ductile transition zone in the crust. Pure water reaches super critical state in excess of $374{ }^{\circ} \mathrm{C}$ and 221 Bar. Deep wells drilled in geothermal fields such as The Geysers and Salton Sea, USA, Kakkonda, Japan, Larderello, Italy, Krafla, Iceland and Los Humeros, Mexico, have encountered temperatures in excess of $374{ }^{\circ} \mathrm{C}$. The high enthalpy fluid can increase energy potential of a well $5 x$ to 10x a standard enthalpy geothermal fluid. This was seen in the flow test of IDDP1 well (Icelandic deep drilling project, Albertsson et al. 2003). With sufficient exploration, drilling, completion, stimulation and corrosion resistance technology exploitation of high enthalpy super critical systems may drastically increase the economic feasibility of geothermal energy.

The depth of supercritical systems has a direct implication of economically feasibility. The target zone will need to be reached within current extended reach drilling programs IDDP-2 has showed the ability to drill wells to a depth of $4000 \mathrm{~m}$. However as would be expected, there were massive complications with drilling and completion equipment and the well took over a year and a half to drill. This differs from the Taupo Volcanic zone because the mafic rock will hit a brittle ductile transition at a much higher temperature. A study by Violay et al. (2012) on the brittle-ductile deformation response of basalt showed that brittle deformation occurs up to $650^{\circ} \mathrm{C}$ and that hydrothermal fluids could circulate in the basaltic crust under Iceland to depths of 4-6 km. This is significantly higher than $300-450{ }^{\circ} \mathrm{C}$ values determined for the brittle-ductile transition of quartzo-feldspathic rocks (Scholz, 1988).

While it is assumed that the ultra-compacted possibly partial metamorphized Felsic greywacke it may be from $350-450^{\circ} \mathrm{C}$. This will limit the zone of that is both permeable and above the temperature and pressures needed to have super critical fluids (temperature greater than $373{ }^{\circ} \mathrm{C}$ and pressure greater than 221 bar).

On the basis of the postulated linkage between the elastic plastic transition and the base of productive reservoirs, a maximum effective confining stress (or equivalent depth) for potentially exploitable supercritical geothermal resources may be predicted for granite and other silicic rocks, as shown Figure

9. This prediction assumes that the maximum feasible stress is that at which permeability is significantly (an order of magnitude) less than the permeability at the transition stress, based on the fact that the onset of the transition does not represent complete loss of permeability. Prior to this nearly all previous models for crustal permeability have invoked stress-independent, temperature dependent permeability behavior as a key first-order control, with permeability decreasing log linearly to a negligibly small value (for example, $10^{22} \mathrm{~m}^{2}$ ) above the BDT temperature (Weis, 2015; Hayba, 1997). There may there may be a 
potentially exploitable zone of permeability near the BDT as it may not decrease log linearly as previously thought.

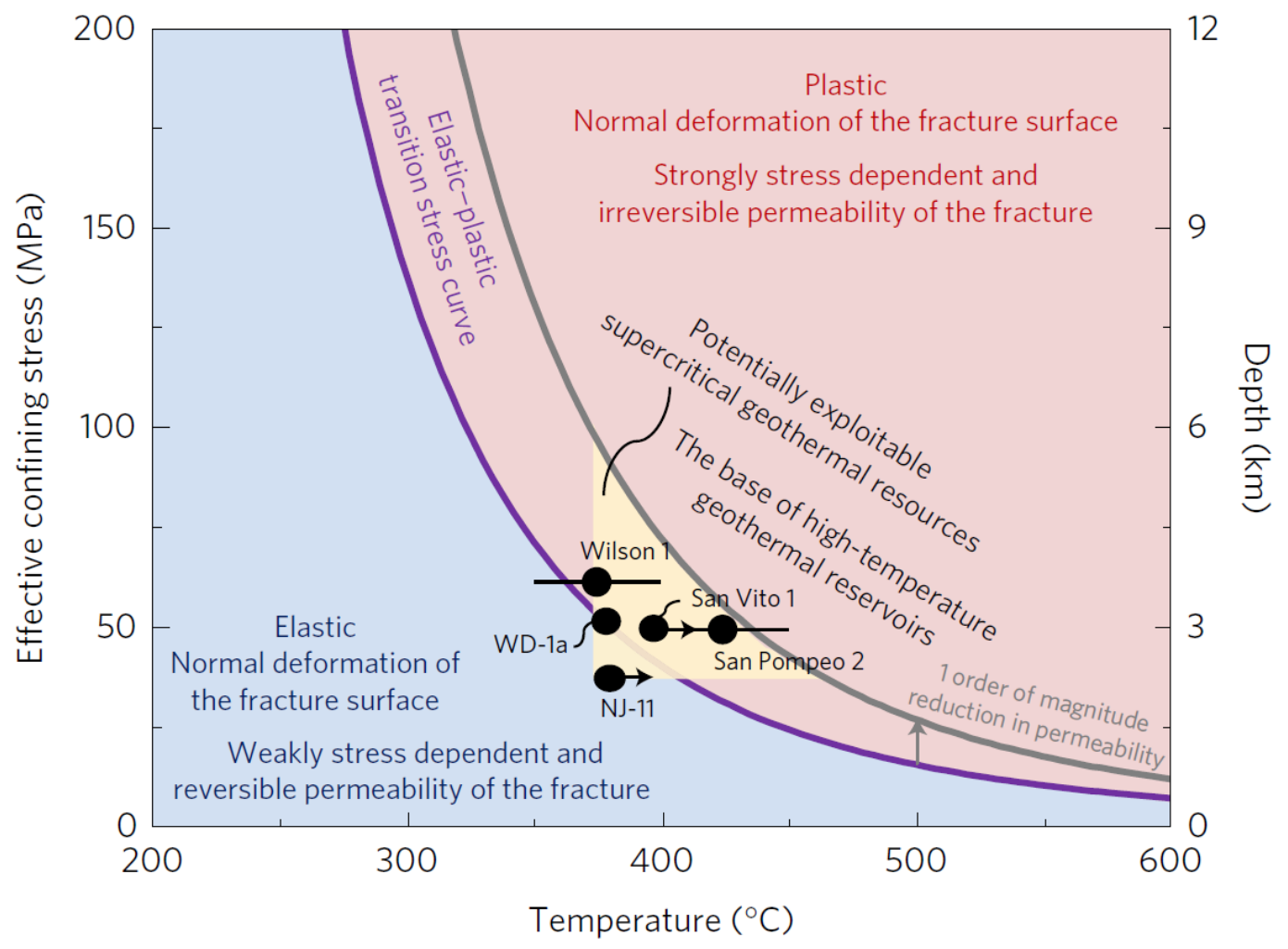

Figure 9: Temperature and effective confining stress (depth) conditions for the base of high-temperature geothermal reservoirs, and potentially exploitable supercritical geothermal resources.

To date geothermal wells in New Zealand have rarely been drilled deeper than $3 \mathrm{~km}$. Temperatures experienced at these depths vary across the geothermal systems, with a typical maximum of $300{ }^{\circ} \mathrm{C}$, which approximates the brittle-ductile transition temperature of quartzo-feldspathic / granite-type rocks. As already discussed, rock composition has a large bearing on the brittle ductile transition temperature. In addition, the fact that seismicity records indicate brittle failure to a depth of up to 6-7 $\mathrm{km}$ in the TVZ implies the thermo-mechanical behavior of New Zealand greywacke basement rocks is different to that of quartzo feldspathic / granite-type rocks.

\section{Modeling Super Critical Systems}

Modeling heat transfer over the BDT is especially difficult because, experimental determination of porosity and permeability of low-porosity rocks at temperature and pressure representative of the BDT has received remarkably little attention in the literature.

A modified version of TOUGH2 is used to in this thesis to simulate flow. TOUGH2 is a numerical simulator for non-isothermal flows of multicomponent multiphase fluids in one, two or threedimensional porous. or fractured media. The of TOUGH2 module used was equation of state one (EOS1). EOS1 simulates water in liquid, vapor phases as well as two phase states. The modification to EOS1 allow simulations to run at Temperatures to $800^{\circ} \mathrm{C}$ and 1000 bar allowing modeling of an additional supercritical phase. In all high temperature geothermal systems non-condensable gases are present in 
the reservoir fluids. The presence of these gases in combination with dissolved salts and change the saturation relation for the reservoir fluid from pure water. Using EOS1 will not account for NCGs and any dissolved solids.

\section{Chapter 3: Literature Review}

The following studies are relevant to supercritical and large-scale convection modeling within the TVZ as well as reservoir modeling of the Rotokawa Geothermal field. The large-scale MT image of the crustal TVZ was used to constrain the model below the reservoir. There is not extensive permeability of Rotokawa or TVZ geothermal fields published in literature this data is usually held as confidential by a geothermal field operator. Assumptions of reservoir permeability and rock properties will have to made based on geology, contour maps and temperature pressure profiles among other geophysics and published literature. A review of similar work will give an idea of permeabilities that can be used as well how large scale TOUGH2 TVZ models are set up.

\section{Magnetotelluric Modeling of the TVZ}

Magnetotelluric data is a passive restivity measurement based. In the geothermal industry the MT data is used to identify the low resistivity altered smectite clay caps that are associated with high temperature geothermal fields. 3-D inversion resistivity techniques give the ability to image potential low restivity zones of partial melt or convection cells. In this study the MT inversion restivity will be used to constrain the model below the current geothermal reservoir.

Using array MT data to image the crustal resistivity structure of the southeastern Taupo Volcanic Zone, New Zealand - (Bertrand et. al 2015)

In 2015 Magnetotelluric data was re-processed from 169 locations covering a $700 \mathrm{~km}^{2}$ region in the south east of the TVZ survey completed by GNS Science. This survey identified used 3-D restivity inversion model to a depth of $10 \mathrm{~km}$. This study discovered that there were isolated zones of low-resistivity $(<30 \Omega \mathrm{m})$ below $3 \mathrm{~km}$ imaged in the basement. These anomalies we located below Rotokawa, Ngatamariki and Ohaaki, and not below Orakei-Korako and Te Kopia as seen in Figure 10. 


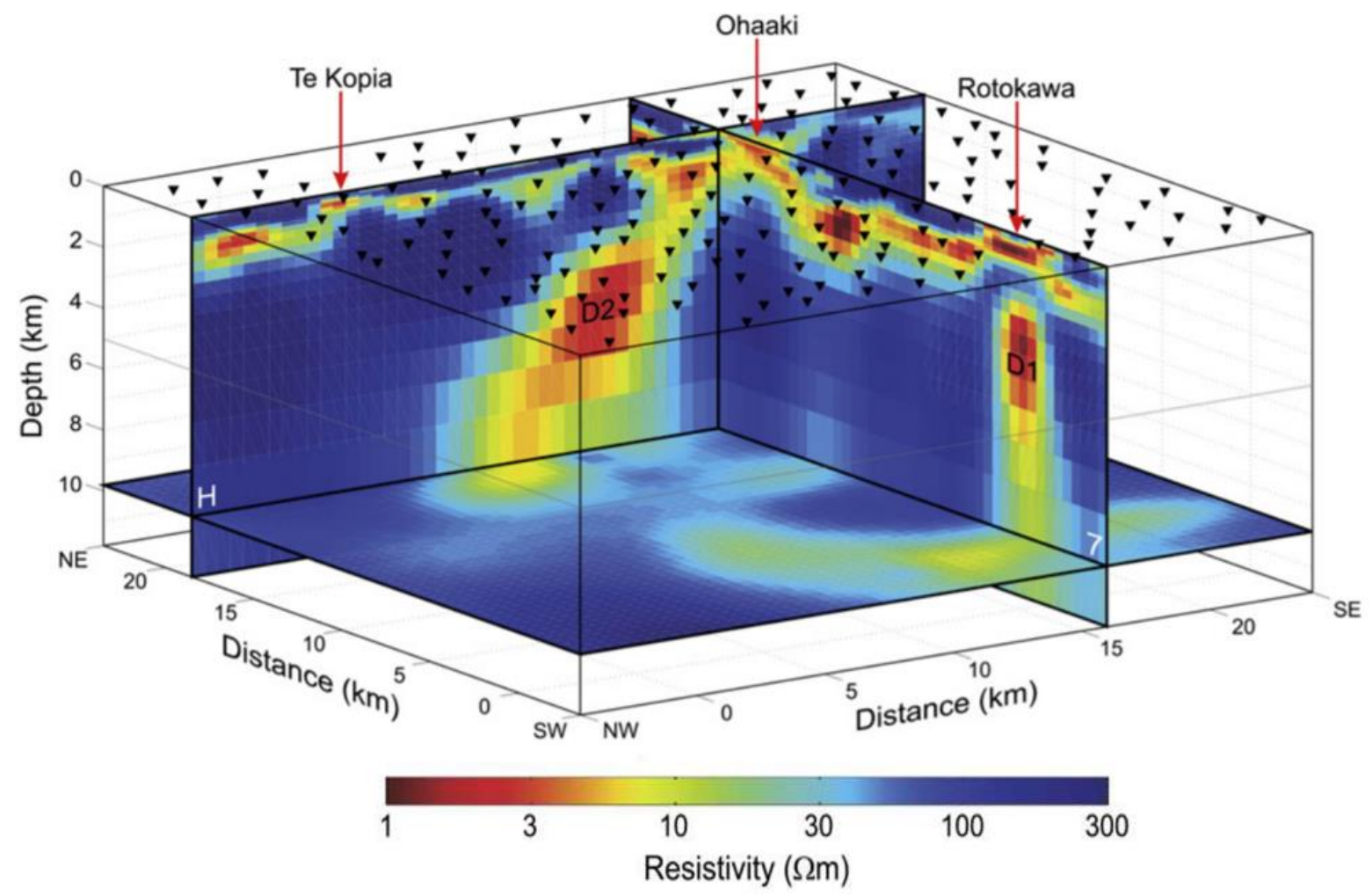

Figure 10: Fence diagram through the 3-D restivity model. Mt site location are shown by black triangles. The location of geothermal fields and low resistivity zones are labeled. (Betrand et. al 2015).

Figure 11 shows a northeast-southwest cross-section though the restivity inversion model hat transects the Rotokawa and Ohaaki geothermal fields with earthquake hypocenters located within $1 \mathrm{~km}$ overlain. Hypocenters are concentrated at locations at or near the top of the D1 low resistivity zone. The hypocenters are based off microseicmic monitoring of Rotokawa between 2008 and 2012 recording 1000 events which are inferred to be caused from thermal stresses produced by the waste fluid at 80--130 $C^{\circ}$ re-injected into the much hotter $\left(330-340{ }^{\circ} \mathrm{C}\right)$ reservoir (Sherburn et al., 2015). 


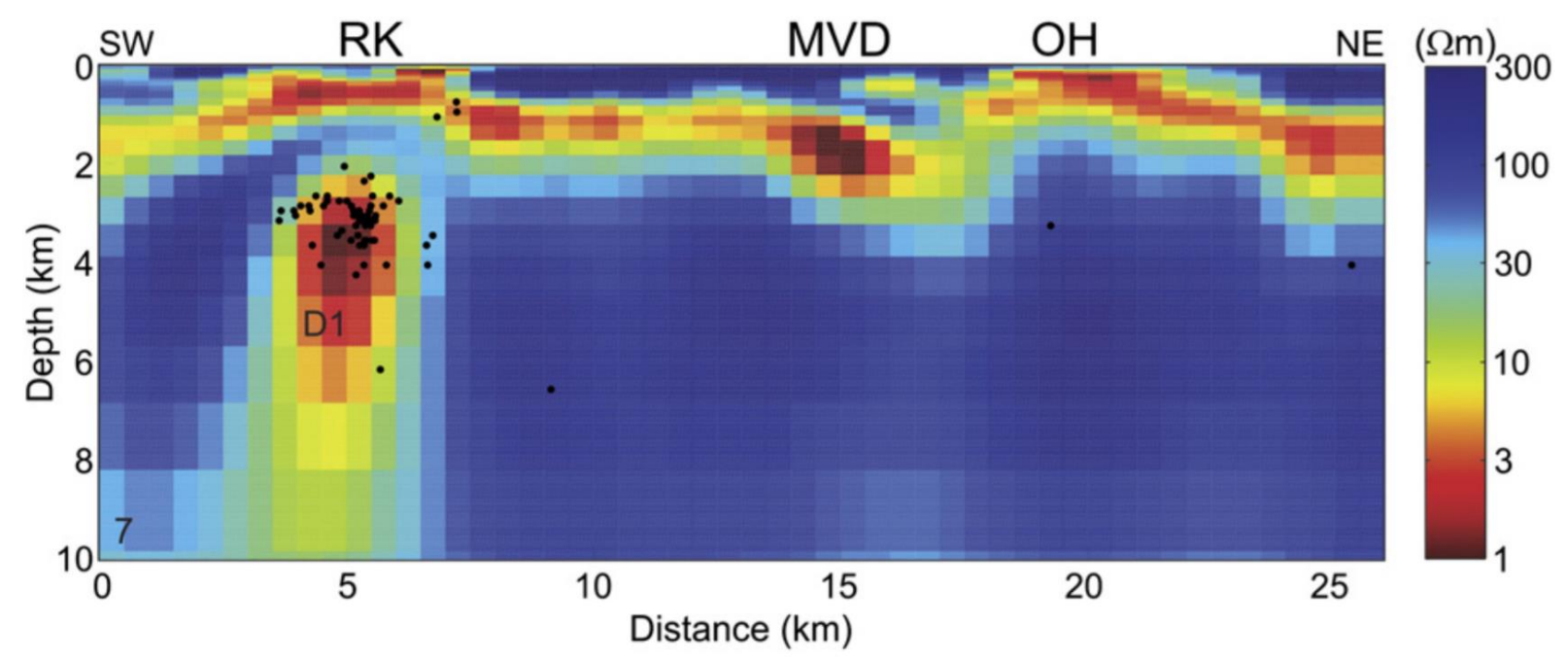

Figure 11: Profile through Rotokawa (RK) and Ohaaki (OH) geothermal fields with earthquake hypocenters (black dots) occurring within $1 \mathrm{~km}$ of the profile overlaid. MVD is the Mihi Volcanic Depression.

The researchers concluded that if the seismicity cuts off at $3.5 \mathrm{~km}$, this is the beginning of the BDT transitions. Assuming an average heat flow of $1255 \mathrm{~mW} / \mathrm{m}^{2}$. If this heat is being transported conductively, the thermal gradient required is $\sim 530^{\circ} \mathrm{C} / \mathrm{km}$. And a thermal conductivity of $2.25-2.5$ $\mathrm{W}-\mathrm{m}^{-1} \mathrm{~K}^{-1}$ for greywacke. Thus, melting could occur within $1 \mathrm{~km}$ of the transition from convective to conductive heat transport. Since the seismicity cuts-off at a depth of $\sim 3.5 \mathrm{~km}$ (Figure 11), a body of partial melt (crystallizing magma) could be present beneath Rotokawa at $\sim 4.5 \mathrm{~km}$ depth (Bertrand et al. 2015). If present, exsolved hypersaline brine and gas would be expected to accumulate at lithostatic pressure above the intrusion in a self-sealed zone below the brittle-ductile transition (Fournier, 1999). Episodic breaches of this nature may be an explanation for hydrothermal eruptions at Rotokawa.

The researchers also note the strong correlation between caldera collapse zones and geothermal fields within the TVZ. The depth slices in Figure 12 show the D1 zone coincides with the margin of near circular low gravity zone which is bordered by Rotokawa. This low gravity zone has been interpreted as a caldera boundary denoted by the yellow line in Figure 12. 

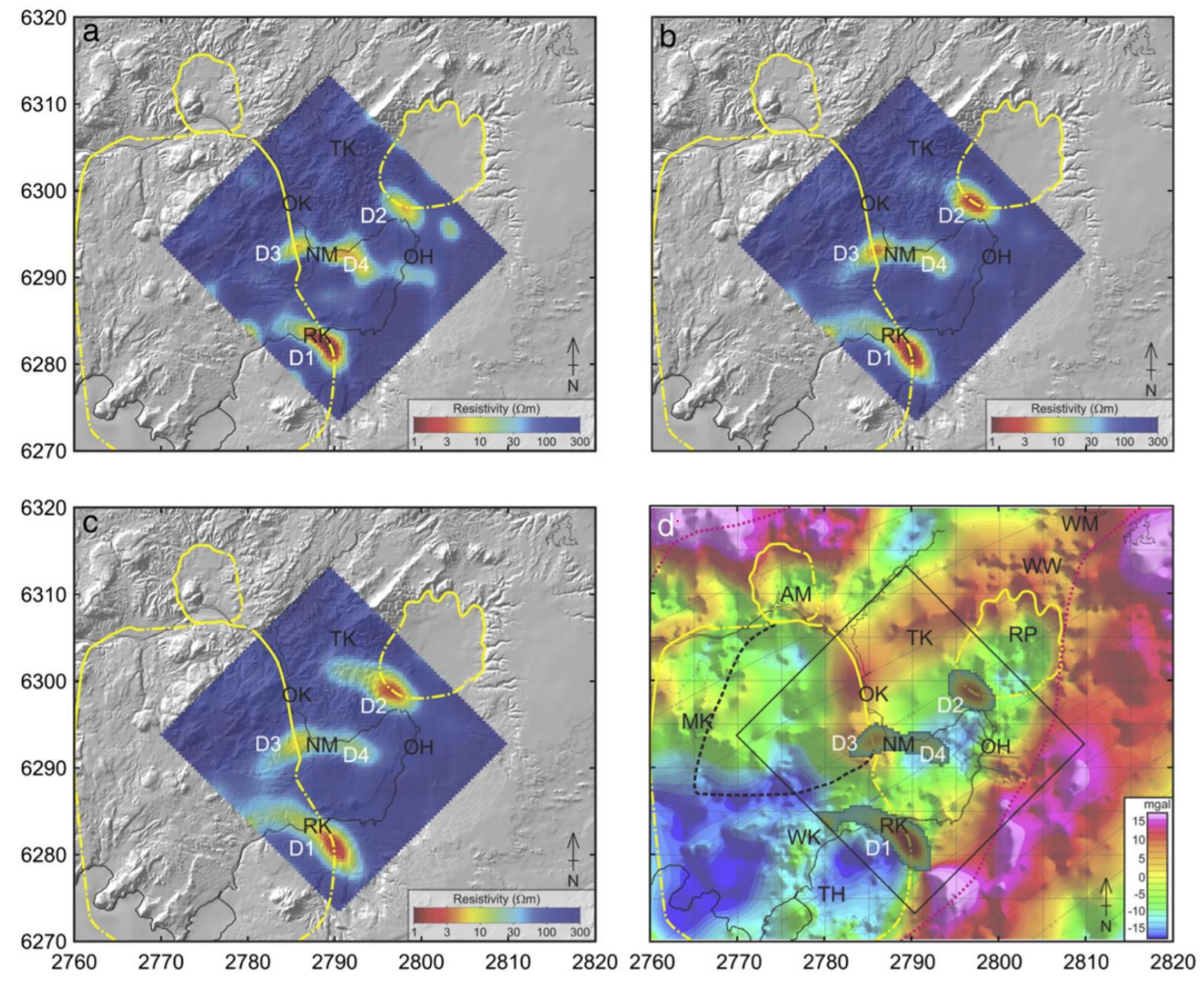

Figure 12: Plan-view slices through the MT resistivity model showing deep (D1, D2, D3 and D4) low-resistivity zones at a) $3.5 \mathrm{~km}$ depth, b) $5 \mathrm{~km}$ depth, and c) $6.5 \mathrm{~km}$ depth. d) Map showing Bouguer gravity values in the survey area with model resistivity b30 $\Omega m$ at $5 \mathrm{~km}$ depth overlaid. The background color shows the DC apparent resistivity map (Bibby et al., 1995) superimposed on a shaded relief map. Low resistivity zones correspond to geothermal systems: TH - Tauhara, WK - Wairakei, RK - Rotokawa, MK - Mokai, NM - Ngatamariki, OK - Orakei Korako, OH - Ohaaki, TK - Te Kopia, AM - Atiamuri, RP - Reporoa, WW Waiotapu Waikiti, and WM - Waimungu. Yellow lines show inferred caldera collapse boundaries (1. Whakamaru, 2. Ohakuri, 3. Reporoa); solid lines show well constrained topographic collapse margins and dashed lines are inferred (Leonard et al., 2010). Dashed black line outlines the Maroa Volcanic Centre and the dashed pink lines bound the northwest and southeast extent of the TVZ (Wilson et al., 1995). Grey lines show the PF - Paeroa Fault and KF - Kaingaroa Fault. b) Similar to above with the regional geological map (Leonard et al., 2010) as the background. Black box in the inset map shows the study area within the North Island of New Zealand.

The researchers concluded that a Rotokawa where thermally induced seismicity marking the transition from hydrostatic to lithostatic pressure (Figure 11) occurs at the top of a deep low resistivity zone imaged in the crust, and estimate the solidus temperature could be reached at $\sim 4.5 \mathrm{~km}$ depth consistent with their interpretation that a young intrusion is feeding heat and exsolved magmatic saline fluid into the Rotokawa geothermal field above (Bertrand et al., 2015). Other researchers have challenged this conclusion but the restivity slices presented in Figure 12 will be used to model the permeability structure below the current Rotokawa reservoir boundary. 


\section{TOUGH2 Modeling of the TVZ}

Numerical modeling of geothermal reservoirs involves a combination of many scientific fields including mathematics, physics, thermodynamics, geochemistry, geology and reservoir engineering. All of these disciplines have to be combined and utilized to create an accurate numerical representation of geologically occurring within the earth.

Factors Controlling Large-Scale Convective Geothermal systems in the Taupo Volcanic Zone (TVZ), New Zealand, (Ratouis and Zarrouk, 2015)

This paper aimed to model a typical TVZ-like geothermal system to natural state using a single largescale model to explore the impact of the system's internal (e.g. caprock permeability, faults) and external (e.g. cold surface water, topography) features on the geometry and location of the heat plume.

2-D models developed included the total extent of the hydrological system (from the surface down to the ductile impermeable crust) and key internal and external features to evaluate if a large-scale, selfcontained 2-D model can account for heat patterns observed in TVZ geothermal fields. Numerous simulations were conducted using super critical- AUTOUGH2 to assess the qualitative impact of each parameter on the convective model of heat distribution.

The conceptual model for this work can be seen in Figure 13.

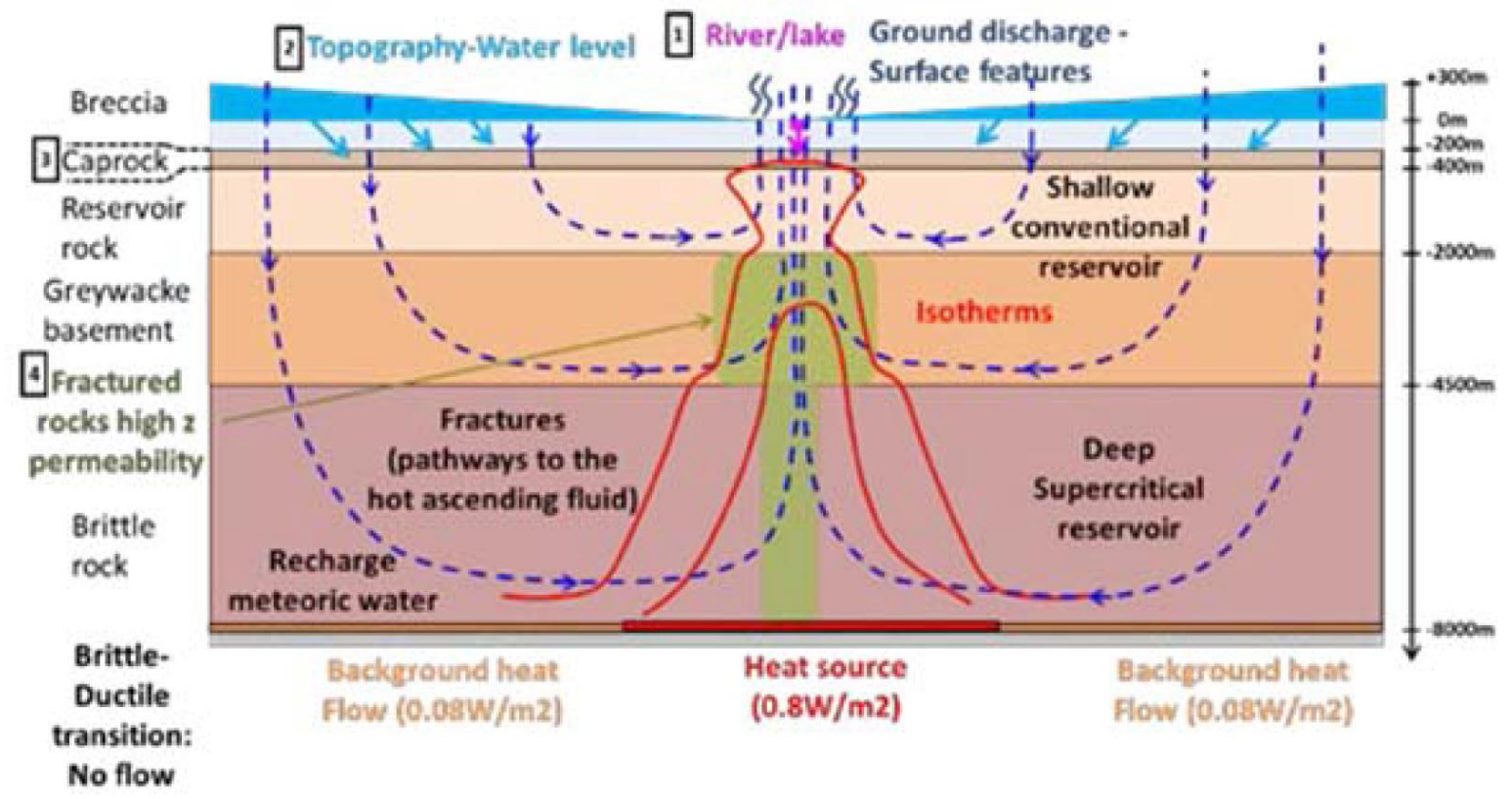

Figure 13: Conceptual Model of an idealized TVZ geothermal system (Ratouis Zarrouk 2015).

The presence of a caprock, topography, surface hydrology and fault structure were all variables tested in this modeling. Temperatures that were modeled could match high temperature fields such as Rotokawa and Ohaaki. Aspects of this 2-D conceptual modeling can be incorporated into the 3-D Rotokawa geothermal system model. The base model temperature can be seen in Figure 14. 
Temperature Vertical Slice Plot alon the X-axis

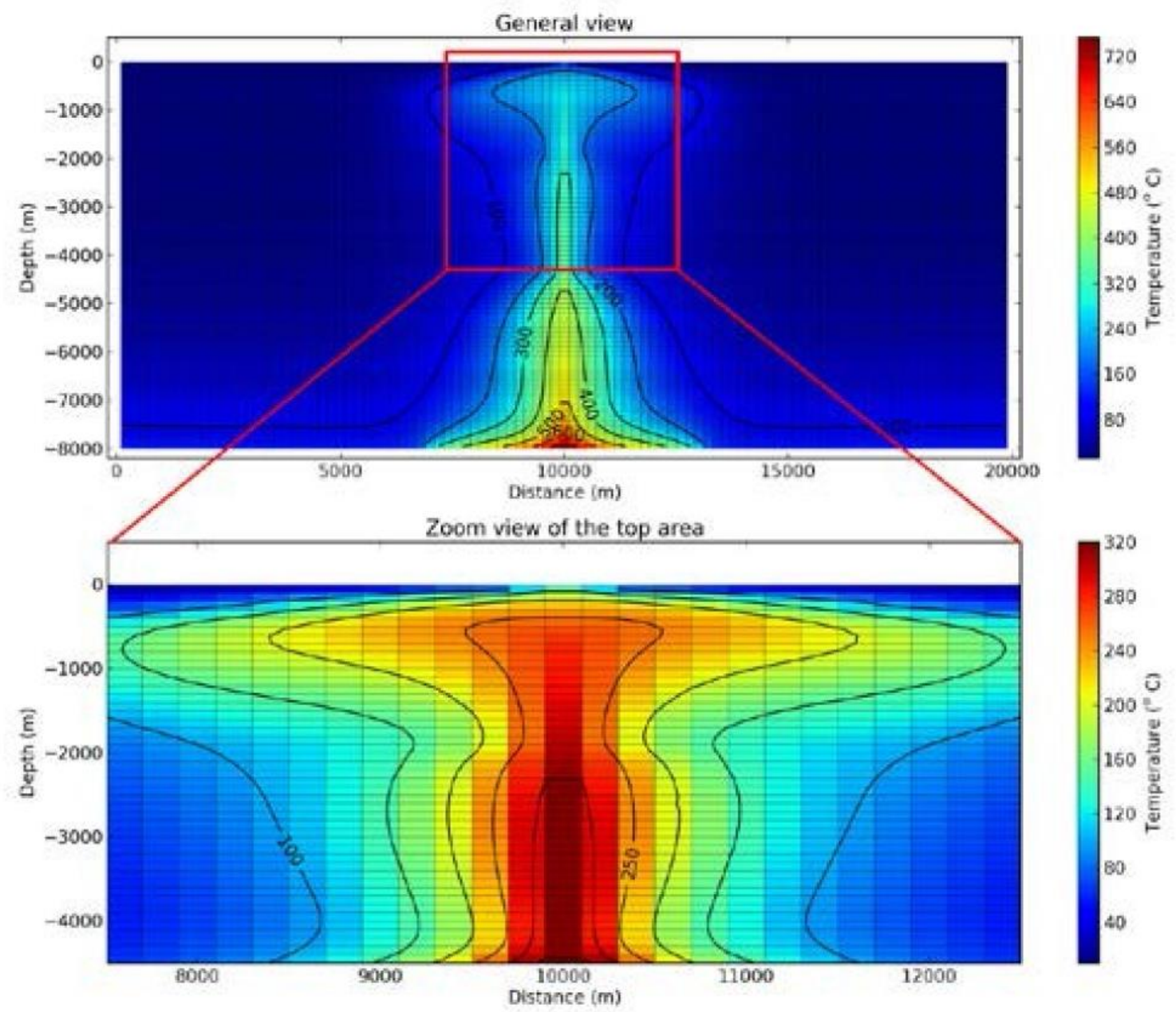

Figure 14: 2-D Base model temperature distribution.

Conclusions of this work are the flowing;

- Vertical faults through the greywacke basement and underlying brittle rock are essential to obtain temperatures encountered in TVZ geothermal reservoirs.

- Low permeability in the cap rock overlying the reservoir is an essential prerequisite to the formation of a geothermal reservoir, but is not required to prevent cold meteoric water surface hydrology.

- Topography controls the large-scale flow of geothermal fluids and offers a close match to 3-D models of the MT impedance tensor data for Rotokawa and Ohaaki from Bertrand et al. 2012

- Models matched MT 3-D inversion models at Ohaaki and Rotokawa.

- Surface hydrology does not show a significant effect on the plume geometry. However, it does influence the location of surface manifestations. 
Three-dimensional model of the deep geothermal resources in the Taupo-Reporoa Basin (TRB), New Zealand, (Kaya et. al 2014)

In this work a three-dimensional TOUGH2 model of part of the Taupo Volcanic Zone (TVZ), consisting of most of the Taupo-Reporoa Basin (TRB) was created to match surface heat flow and reservoir temperature. A $38 \mathrm{~km} \times 82 \mathrm{~km} \times 6 \mathrm{~km}$ model was created and can be seen in Figure 15. There were 74 different rock types used in the whole model, they are grouped into categories: faults, volcanic centers.

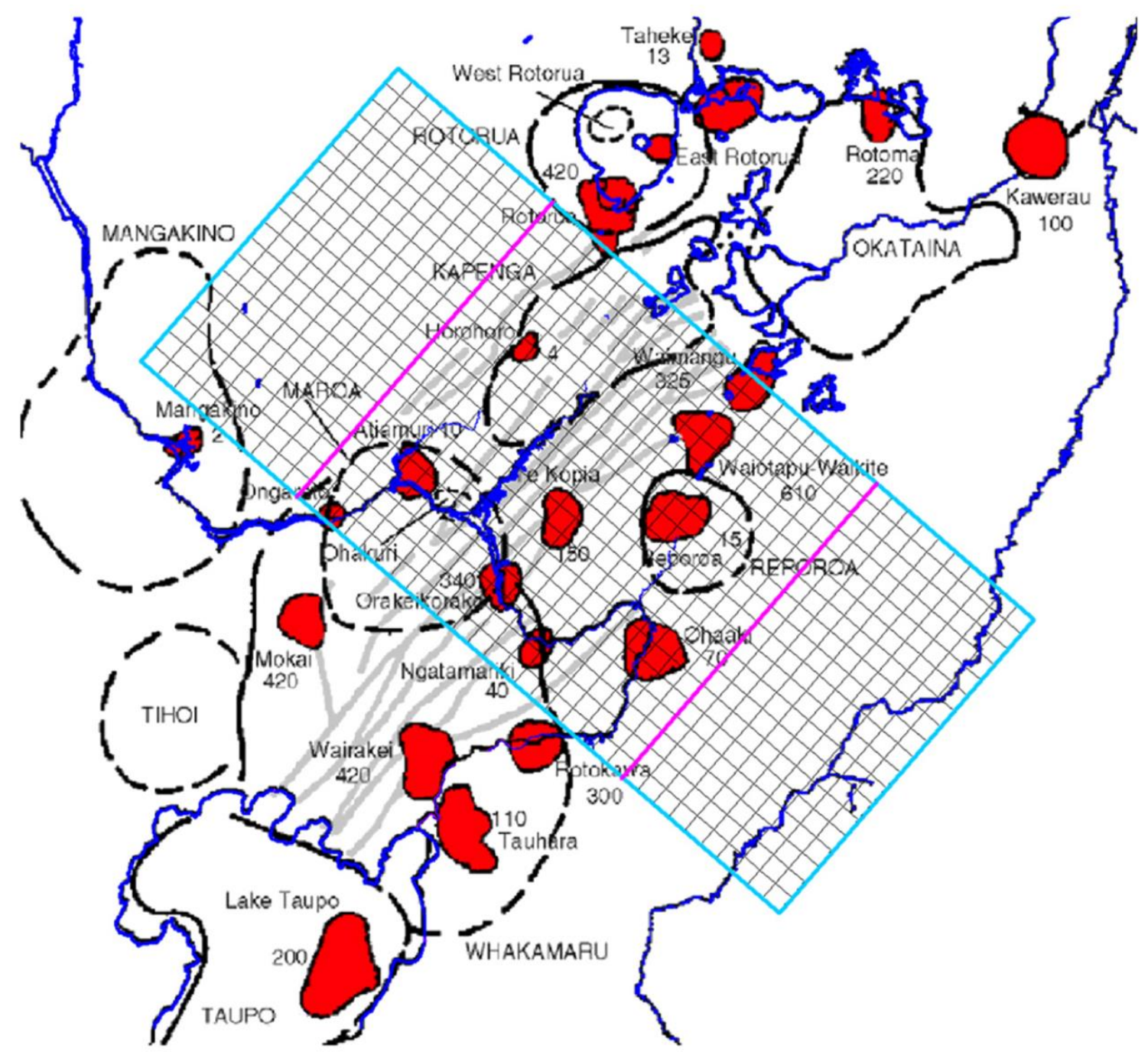

Figure 15: Model area (inside the blue lines), location of geothermal fields (red areas), TFB (grey lines) and known volcanic centers (dashed black lines) within the TRB (Kissling and Weir 2005) surface heat flows (MW) are labeled next to the geothermal fields.

The temperature distribution results for Model IV at a depth of $-2950 \mathrm{mRSL}$ are shown in Figure 16 The temperatures could only be matched in the fourth iteration of the model when the heat flow at the base of the model could be adjusted. The rock properties and permeabilities used in Model IV can be seen in appendix C.1.3 to give an idea for permeabilities that may need to be used in the Rotokawa geothermal system model. 

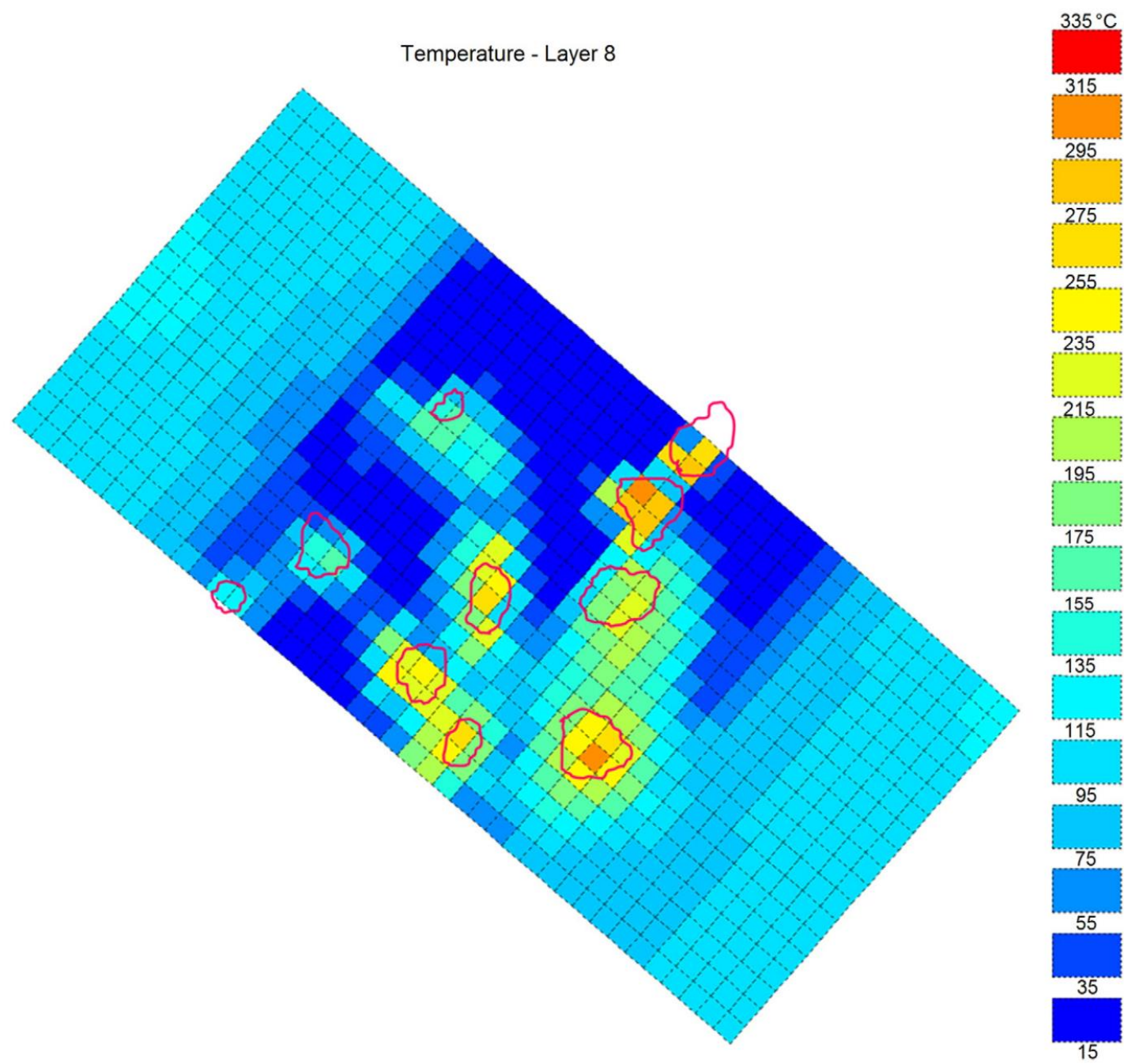

Figure 16: Temperature $\left({ }^{\circ} \mathrm{C}\right)$ distribution at a depth of 2950 mRSL for Model IV (E Kaya et al. 2014)

The final model (Model IV) correctly predicts the position of the geothermal plumes for the fields located in the TRB, their surface heat flows and the temperatures in the upflow zones at about $3 \mathrm{~km}$ depth. The match to the temperatures in particular is an improvement on the results achieved by (Kissling, 2004) for the whole TVZ. Most of his modelled geothermal systems were too cold although the heat flows were reasonable indicating that overall the mass flows and permeabilities were too high. Experimentation with the model showed that with a very simple permeability structure, obtained by dividing the model area into three geological units (exterior, deep interior and shallow interior), it was possible to obtain a steady state convective system and some large plumes close to the real locations of the actual geothermal fields. However, in order to obtain the correct locations of the discrete plumes, and to match the surface heat flows and temperatures in the model, a variable heat input over the base boundary is required. Additionally, a relatively complex permeability distribution had to be introduced, including various geological units and with several sub-units or rock-types. 
Numerical Modelling of the Influence of Geology and Groundwater Recharge on Geothermal Systems in the central TVZ (S. C. Pearson-Grant, S. D. Milicich, P. A. White and W. M. Kissling) Another large scale TOUGH2 model was modeled from Ngatamariki in the south-west to Waiotapu in the north-east and comprises an area of approximately $870 \mathrm{~km}^{2}$. Within this area there are two producing geothermal fields (Ohaaki and Ngatamariki) and five undeveloped systems (Waiotapu, Waikite, Reporoa, Te Kopia, and Orakei Korako). The area hosts hot springs, geysers, collapse calderas, faults, and groundwater catchment zones, making it ideal to study the effects of geological structures and recharge on regional fluid flow.

In this paper, the researchers present the initial results from a numerical model that is based on a hydrogeological model of a central portion of the TVZ. The complexity of this model will be built up over time, and it will be used to explore a range of questions, for example:

- Are the extents of geothermal systems predominantly linked to structural boundaries, or to the natural separation of convective cells?

- What is the nature of connection between neighboring geothermal systems?

- Can convective cells be stable on the timescales inferred for geothermal systems in the TVZ?

- What rock properties are feasible to allow fluid upflow at the mass rates and temperatures that we observe in the geothermal systems?

- Does shallow groundwater recharge affect the locations and rates of geothermal circulation?

The model size was $25 \times 34 \times 5 \mathrm{~km}$ depth. Cell blocks were $500 \times 500 \times 250 \mathrm{~m}$, the top boundary reached a maximum of $\sim 960 \mathrm{~m}$. For the purposes of this initial, simple study the surface was assumed to be the water table and the model was fully saturated with water. A uniform heat source at the base of the model of $700 \mathrm{~mW} / \mathrm{m}^{2}$ was used as a representative average of the TVZ (Bibby et al., 1995). The model was run for 1 million years. Homogeneous, isotropic rock properties were modelled to explore what permeability ranges would result in TVZ-like geothermal systems. The permeability range included was based on the literature as discussed in Milicich et al. (2017).

Permeabilities lower than $1 \mathrm{E}-15 \mathrm{~m}^{2}$ would not allow sufficient convection to transport the heat bottom of the model reaching $373{ }^{\circ} \mathrm{C}$ and TOUGH2's temperature limit. $1.2 \mathrm{E}-15$ and $2 \mathrm{E}-15 \mathrm{~m}^{2}$ with a max temperature of $311^{\circ} \mathrm{C}$ and $276{ }^{\circ} \mathrm{C}$ respectively. Permeabilities higher than $5 \mathrm{E}-15 \mathrm{~m}^{2}$ allowed extensive convection and permeabilities $s$ greater than $8 \mathrm{E}-12 \mathrm{~m}^{2}$ resulted in low temperature convection and convergence simulation failures. The Summary of the results are shown in Table 1 below. 


\begin{tabular}{|l|l|l|l|}
\hline $\begin{array}{l}\text { Permeability } \\
\left(\mathrm{m}^{2}\right)\end{array}$ & Top BC & $\begin{array}{l}\text { Max T } \\
\left({ }^{\circ} \mathrm{C}\right)\end{array}$ & Notes \\
\hline $1 \times 10^{-15}$ & Infinite recharge & 374 & Temperature reached TOUGH2 limit after 80k years \\
\hline $1.2 \times 10^{-15}$ & Infinite recharge & 311 & Convection in topographic lows \\
\hline $2 \times 10^{-15}$ & Infinite recharge & 276 & Convection in topographic lows \\
\hline $5 \times 10^{-15}$ & Infinite recharge & 246 & Extensive convection \\
\hline $1 \times 10^{-14}$ & Infinite recharge & 172 & Laterally continuous convection \\
\hline $8 \times 10^{-12}$ & Infinite recharge & 31.5 & Onset of convective plumes along topographic lows, converged after $11 \mathrm{k}$ years \\
\hline $2 \times 10^{-9}$ & Infinite recharge & 30 & Cold, conductive, converged after 63 years \\
\hline $1 \times 10^{-15}$ & No recharge & 374 & Sparse convection in topographic lows \\
\hline $2 \times 10^{-15}$ & No recharge & 275 & Convection in topographic lows \\
\hline $5 \times 10^{-15}$ & No recharge & 243 & Extensive convection \\
\hline $1 \times 10^{-14}$ & No recharge & 173 & Laterally continuous convection \\
\hline
\end{tabular}

Table 1: Summary and parameters of TVZ TOUGH2 model.

The models in this study are extremely simple, with a single homogeneous rock-type and uniform heat at the base. However, they give surprisingly promising results (Figure 17). Topography is included in the model and this appears to be a key control (Table 1). Convective upwelling occurs below topographic lows. This is consistent with the 2-D modelling of Ratouis et al. (2016), as well as the qualitative observation that geothermal systems in the TVZ tend to occur near the river. This may be due in part to the fact that there is a smaller column of water and rock at the topographic lows creating smaller overpressure at depth and therefore encouraging upflow in those areas. Topographically driven fluid flow has also been found to concentrate heat into valleys at the alpine fault (Sutherland et al., 2017). 


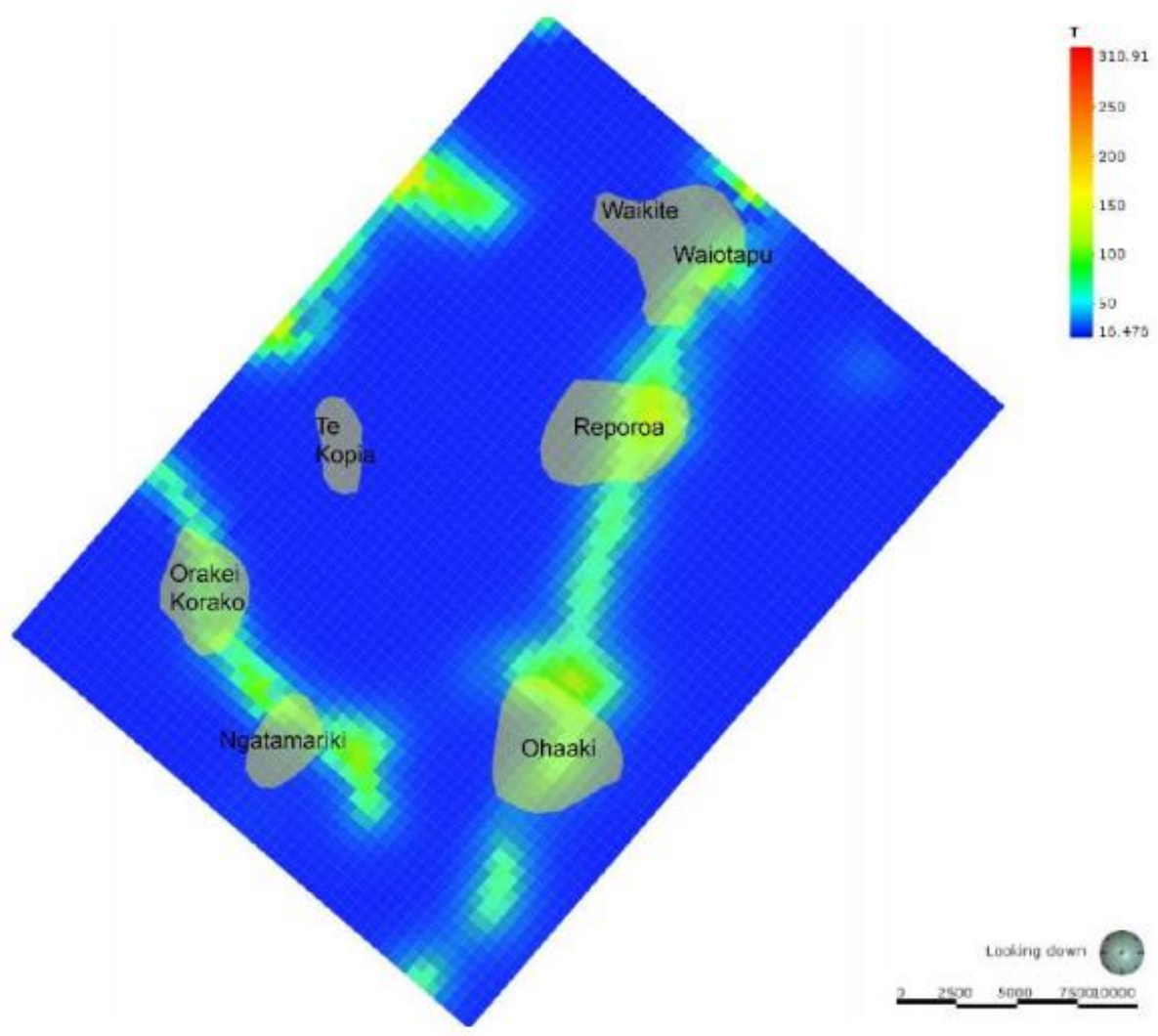

Figure 17: Model results, warm colors represent hotter near surface temperature with cooler colors representing colder temperatures. Geothermal fields are overlain in tan and labeled.

Topography appears to be a major influence on the location of geothermal systems in the TVZ. Convective upwellings occur in topographic lows. Even with a single, uniform rock type and a uniform heat source at depth, many of the hot upwellings occur in the same locations as geothermal systems of the TVZ. However, convective upwellings are more extensive than the systems observed in the TVZ, and Te Kopia is not in a topographic low and cannot be explained by this mechanism. Future work will explore the effects of faulting, caldera boundaries, variable recharge and different rock types on fluid upflow.

The summary of the results found even with a simple single porosity model the driving factor for the location of hot upflow was concentrated in topographic lows, a factor that was found in the previously mentioned Ratouis and Zarrouk, 2015 modeling. This model emphasizes the impact on topography on the location for upflow. Another important parameter in this modeling is the permeability used in the model. Lower permeabilities allow for higher temperatures convection. The Rotokawa geothermal TOUGH2 model faulting, caldera boundaries, variable recharge and different rock types on the upflow that this model has not used. 


\section{Rotokawa Reservoir Modeling}

The conceptual model and reservoir model structure will largely be based off the Rotokawa reservoir model by Bowyer and Holt 2010. Although a newer model has been developed since 2010 (Hernandez et. al 2015) the simplicity geology and structure will be easier to model with the large grid block and layers. Updates to the conceptual model and geology since 2010 can be incorporated into the rock properties selected for TOUGH2 rock types.

\section{Case Study: Development of a Numerical Model by a Multi-Disciplinary Approach, Rotokawa} Geothermal Field, New Zealand, (Bowyer and Holt, 2010)

A comprehensive multi-disciplinary conceptual model was developed for the Rotokawa Geothermal Field by integrating natural state temperatures, geology y, geophysics, geochemistry, tracer test results and downhole pressures into a complete geoscientific description of the resource. Through a numerical model construction process, each component of the conceptual model was converted into numerical.

Additional well, geophysical, reservoir engineering and geologic data has been collected since the creation go this reservoir model and will be incorporated to use as the conceptual model for the Rotokawa geothermal system model.

The model contains 27 layers extending from surface to $4250 \mathrm{~m}$ below sea level. Each layer contains 4230 blocks, for a total of 114,210 grid blocks in the computational grid. Horizontally, the computational grid is a really large enough to cover the entire Rotokawa geothermal resource, extending beyond the inferred resource boundary in all directions. Vertically, the computational grid is thick enough to extend from ground surface to the origins of hot upwelling fluids below the geothermal reservoir. 


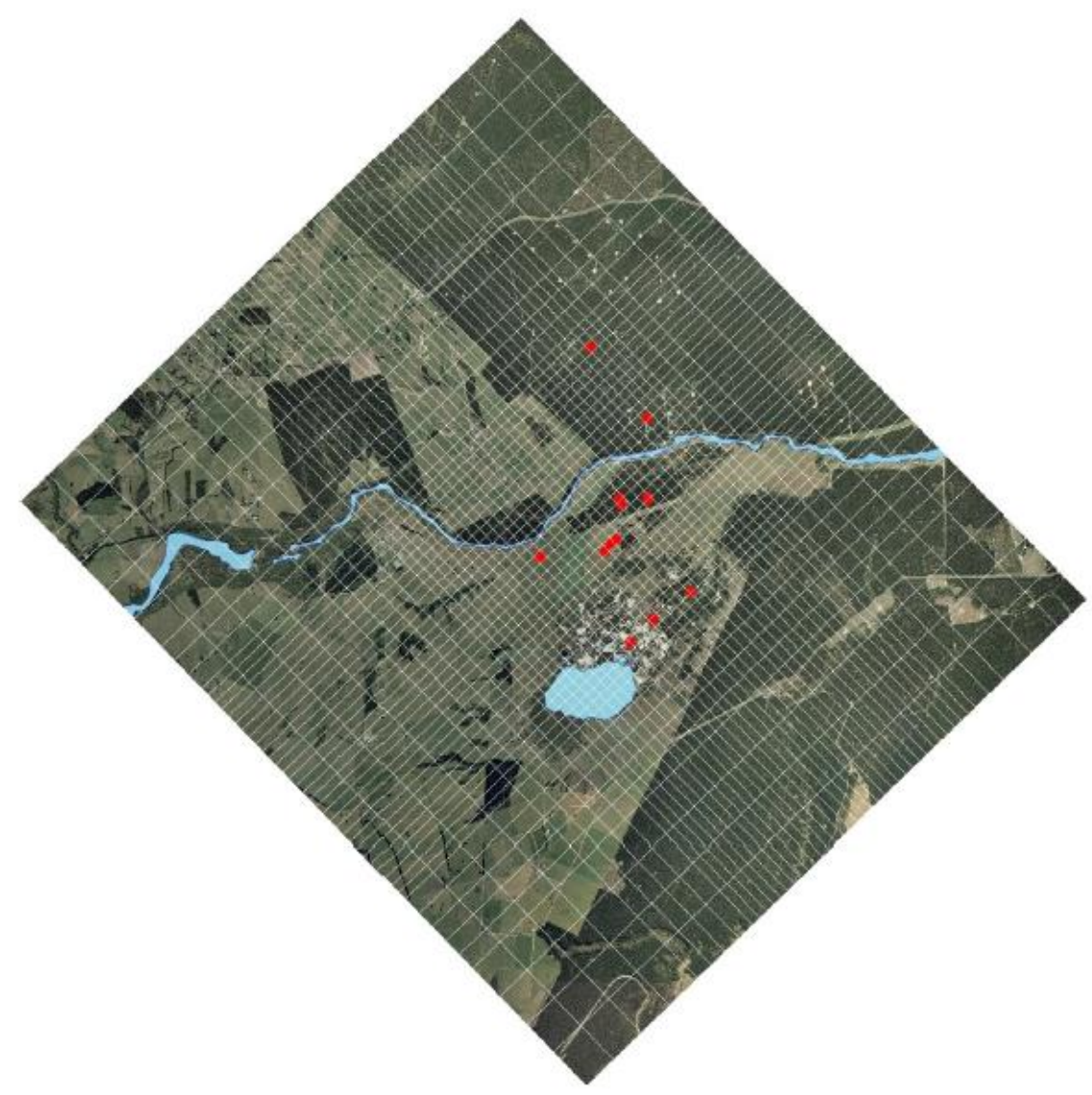

Figure 18: Aerial photo of the Rotokawa region that is included in the numerical model. The yellow lines are the borders of computational grid blocks.

Natural state temperature isotherms have been interpolated from stable downhole temperatures. The hottest wells in the field are RK4, RK5 and RK17 with bottom hole temperatures of at least $330^{\circ} \mathrm{C}$, suggesting that the deep upflow for the geothermal system lies between these wells. Bottom hole temperatures decline to the north with $\sim 310^{\circ} \mathrm{C}$ in RK6 and $280^{\circ} \mathrm{C}$ in RK8. RK17 encountered the shallowest occurrence of $330^{\circ} \mathrm{C}$ fluid at approximately $1500 \mathrm{~m}$ below sea level. In the west the fault intersected by RK17 influences the shape of the deep isotherms, suggesting that it is a major conduit for upflow and that it defines the western boundary of the geothermal reservoir. With the exception of RK4, all wells show a temperature reversal above approximately $700 \mathrm{~m}$ below sea level.

Maps were created showing the distribution of natural state isotherms at specific elevations, a selection of which are shown in Figure 19. The map at $2000 \mathrm{~m}$ below sea level shows the deep upflow for the geothermal system between RK4, RK14 and RK17. The upflow associated with the fault encountered in RK17 can be identified as a small area of fluid of $>330^{\circ} \mathrm{C}$ at $1500 \mathrm{~m}$ below sea level. At $500 \mathrm{~m}$ below sea level an up flow of $>280^{\circ} \mathrm{C}$ fluid from the geothermal reservoir into shallower aquifers can be seen between RK1, RK3 and RK4. 

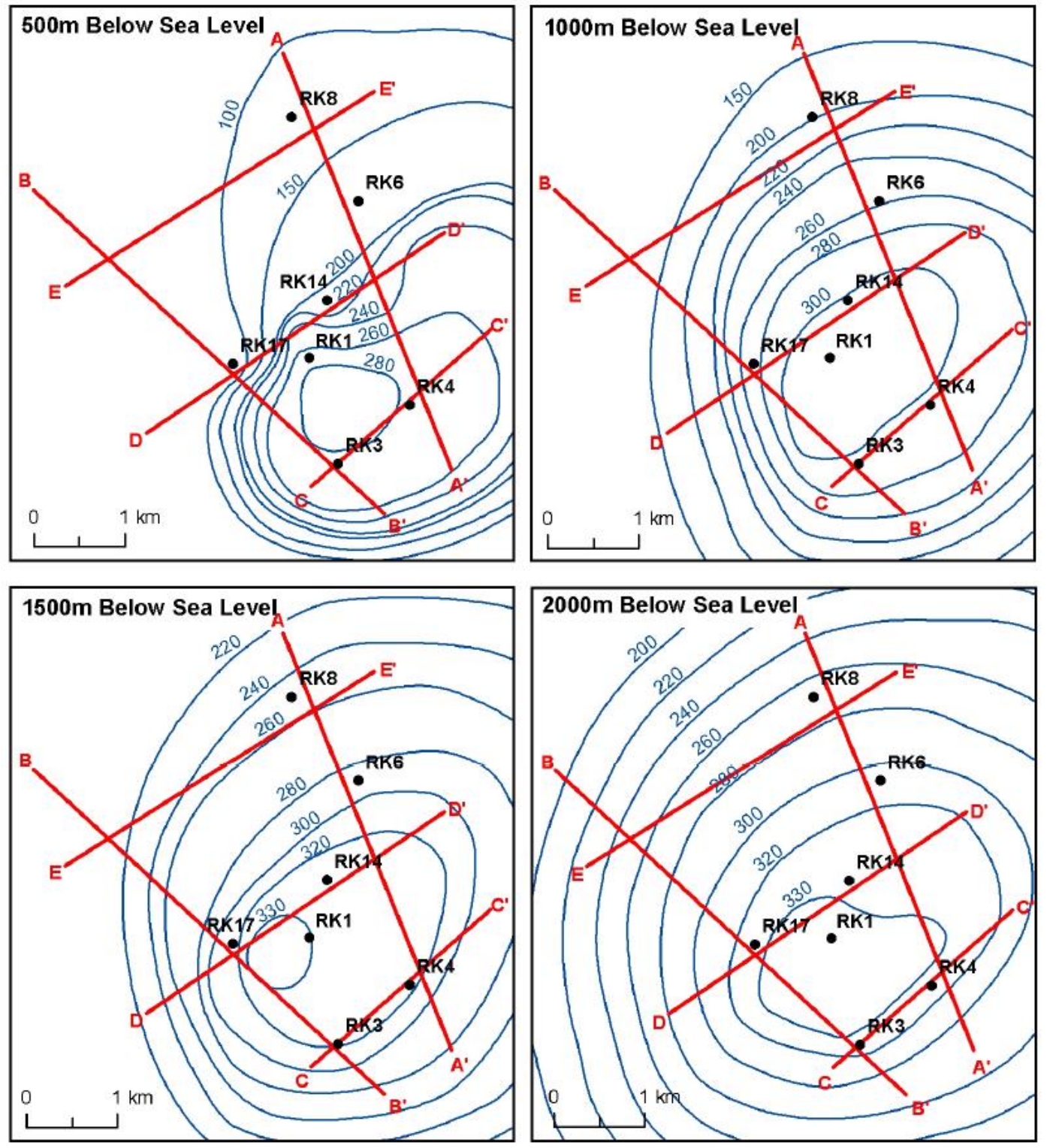

Figure 19: Natural state temperature isotherms $\left({ }^{\circ} \mathrm{C}\right.$ ) at $500 \mathrm{~m}, 1000 \mathrm{~m}, 1500 \mathrm{~m}$ and $2000 \mathrm{~m}$ below sea level (selected wells are also shown).

The geologic, structure and will be explained in more detail as this model was used as the conceptual model for the shallow Rotokawa reservoir zone for the large-scale geothermal system model.

\section{Chapter 4: Reservoir Modeling Methodology}

\section{TOUGH2}

TOUGH2 is numerical simulation program for multidimensional fluid and heat flows of multiphase, multicomponent fluid mixtures in porous and fractured media. This is the primary simulation software used in the geothermal industry. The TOUGH2 software was modified to allow simulation of supercritical fluids. Each block is assigned rock properties that represent the rock located at that depth and location in the earth. TOUGH2 solves mass and energy balance equations that describe heat flow in general 
multiphase, multi component systems. Different versions of TOUGH2 exist, that allow for modeling with $\mathrm{CO} 2$, air, hydrogen, brine among others. The Version that was used in this modeling is a modified version of 'EOS1' (equation of state) to allow for simulations to reach to temperatures of 800C and 1000 MPa. EOS1 This allow for modeling of Water in vapor or liquid phases. The equations for solving mass and energy balance, as well as spatial discretization can be seen in appendix A.2..

"TOUGH2 is a numerical simulation program designed for multi-dimensional fluid and heat flows of multiphase, multicomponent fluid mixtures in porous and fractured media. It is used in different areas, such as geothermal reservoir engineering, nuclear waste isolation studies, environmental assessment and remediation, flow and transport in variably saturated media and aquifers. TOUGH2 utilizes different equation of states (EOS). These are EOS1 (water, water with tracer), EOS2 (water, CO2), EOS3 (water, air), EOS4 (water, air, with vapor pressure lowering capability), EOS5 (water, hydrogen), EOS7 (water, brine, air), EOS7R (water, brine, radionuclide 1, radionuclide 2, air), EOS8 (water, air, oil), EOS9 (saturated-unsaturated flow), EWASG (water, $\mathrm{NaCl}$, non-condensable gas). TOUGH2 solves mass and energy balance equations. Fluid advection is represented by Darcy's law. Moreover, TOUGH2 utilizes equations for diffusive mass transport. TOUGH2 uses necessary equations to define real cases where heat flow occurs by both conduction and convection (Appendix A). It uses the assumption that there exists thermodynamic equilibrium in all grid blocks at all times. "Integral finite difference" method (IFPM) is used for space and time discretization. Time is discretized fully implicitly (Appendix A). With the integral finite difference method, TOUGH2 has the advantage of being applicable to regular and irregular discretization. Moreover, double and multiple-porosity methods can be used for fractured media. Space and time discretization results in strongly coupled nonlinear algebraic equations. NewtonRaphson iteration is used for solving these equations. Matrix including primary thermodynamic variables to be calculated, secondary variables functions of primary thermodynamic variables are formed at each iteration. The matrix is solved using one of the linear equation solvers: direct solver, bi-conjugate gradient solver, Lanczos-type bi-conjugate gradient solver, generalized minimum residual solver, stabilized bi-conjugate gradient solver. Automatic time step adjustment in which the aim is to use the highest time step size without exceeding certain number of iterations is a recommended option to be used in the program" (Pruess et al., 1999).

A three-dimensional TOUGH2 model will be set up and evaluated the flow within the Rotokawa geothermal system to understand the complex fault structure and the convection system that provides upflow into the reservoir. In particular the because Rotokawa has reached the hottest temperature in New Zealand and as a result arguably the best field to begin exploration of drilling and production super critical fluid zones.

\section{Rotokawa Geothermal System Model}

Due to the large scale of the Rotokawa model being built, a simplified geological concept model was used based off modeling done in 2010 by mighty river power of the Rotokawa geothermal system. Modeling to match steady state conditions with the vertical cell resolution limits the complexity of the conceptual model. In addition, no permeably, pressure or well drilling data was given by the current Rotokawa field operator Mercury NZ, and is a major data limitation, so keeping the conceptual model simple will be easier.

The below currently explored Rotokawa Geothermal reservoir the model will be built constrained from the off of the magnetologic slices from Bertrand et. al 2015 in addition to the rock properties of quartzo 
feldspathic rocks at the base permeable TVZ crust. Deterministic iterations will have to be completed in the modeling process to obtain a good natural state temperature and pressure match.

The Rotokawa geothermal field is a liquid dominate system with some boiling after fluid production began. Matching data will primarily be based off temperature published in Hernandez et al. 2015 (Figure 21). Wells RK14, RK17, RK24, RK19 and RK21 were selected to represent the Central, West, South East, North, and South West areas of the field respectively.

\section{Rotokawa Reservoir Conceptual Model}

A conceptual model is built as a basis of geology, faults and flow pathways. The conceptual model is based off molding done by 'Case Study: Development of a Numerical Model by a Multi-Disciplinary Approach, Rotokawa Geothermal Field, New Zealand' (Bowyer and Holt 2010). The simplified stratigraphy was chosen over a more detailed conceptual model published in D.D. McNamara et al. 2016. This is because model size is much larger in area and depth and as a result the grid size and layer sixes will be too large and will not allow for that detailed of reservoir model. A reservoir model that may be created by a geothermal field operator in order to simulate geothermal production and injection.

Primary inputs to the conceptual model development process are geology and natural state temperatures. Geophysics, geochemistry, tracer test results and downhole pressures provide supporting information. The subsurface geology of the Rotokawa Geothermal Field was interpreted from drill cuttings and cores. The geology for the is a basement greywacke is overlain by the Rotokawa Andesite, a sequence of andesite lava flows and breccias up to $2000 \mathrm{~m}$ thick. Differences in the elevation at which the Basement Greywacke and Rotokawa Andesite are encountered in wells suggest the occurrence of a series of SW-NE striking normal faults, parallel to the structural trend of the Taupo Volcanic Zone, which have resulted in a structural trough (graben) between RK4 and RK6.

Overlying the Rotokawa Andesite, and infilling the graben, are the volcaniclastic and sedimentary deposits of the Tahorakuri and Waikora formations (members of the Reporoa Group), which are in turn overlain by the Wairakei Ignimbrite. The elevation of the top of this ignimbrite is relatively constant across the field suggesting no, or very little, reactivation of the graben-forming faults since its deposition. Overlying Wairakei Ignimbrite are the rhyolitic tuffs, ashes and breccias of the Waiora Formation. Haparangi Rhyolite lavas and breccias occur within the Waiora Formation, which is then overlain by mudstones, siltstones and sandstones of the Huka Formation intercalated with the Parariki hydrothermal eruption breccias.

Permeable zones in the deep wells (RK5, RK9, RK13-14, RK16-17) indicate that the geothermal reservoir is primarily within the Rotokawa Andesite. In RK17 permeable zones occur on either side of the fault intersection, suggesting that reservoir permeability is controlled, at least in part, by fault structures. However, as other wells are not known to directly intersect fault structures, other factors (e.g. lava flow boundaries, cooling joints) must also play a role in providing permeability and controlling fluid flow. Permeable zones in the shallow wells (RK1, RK11-12), and fluid losses while drilling, indicate the occurrence of high permeability in both the Waiora Formation and Haparangi Rhyolite.

A cross sections of cross sections are shown Figure 20 . The influence of proposed faults on the distribution of geological formations is evident at $1000 \mathrm{~m}, 1500 \mathrm{~m}$ and $2000 \mathrm{~m}$ below sea level, while at shallower levels the geology is controlled by the distribution of rhyolite lava domes and flows. 


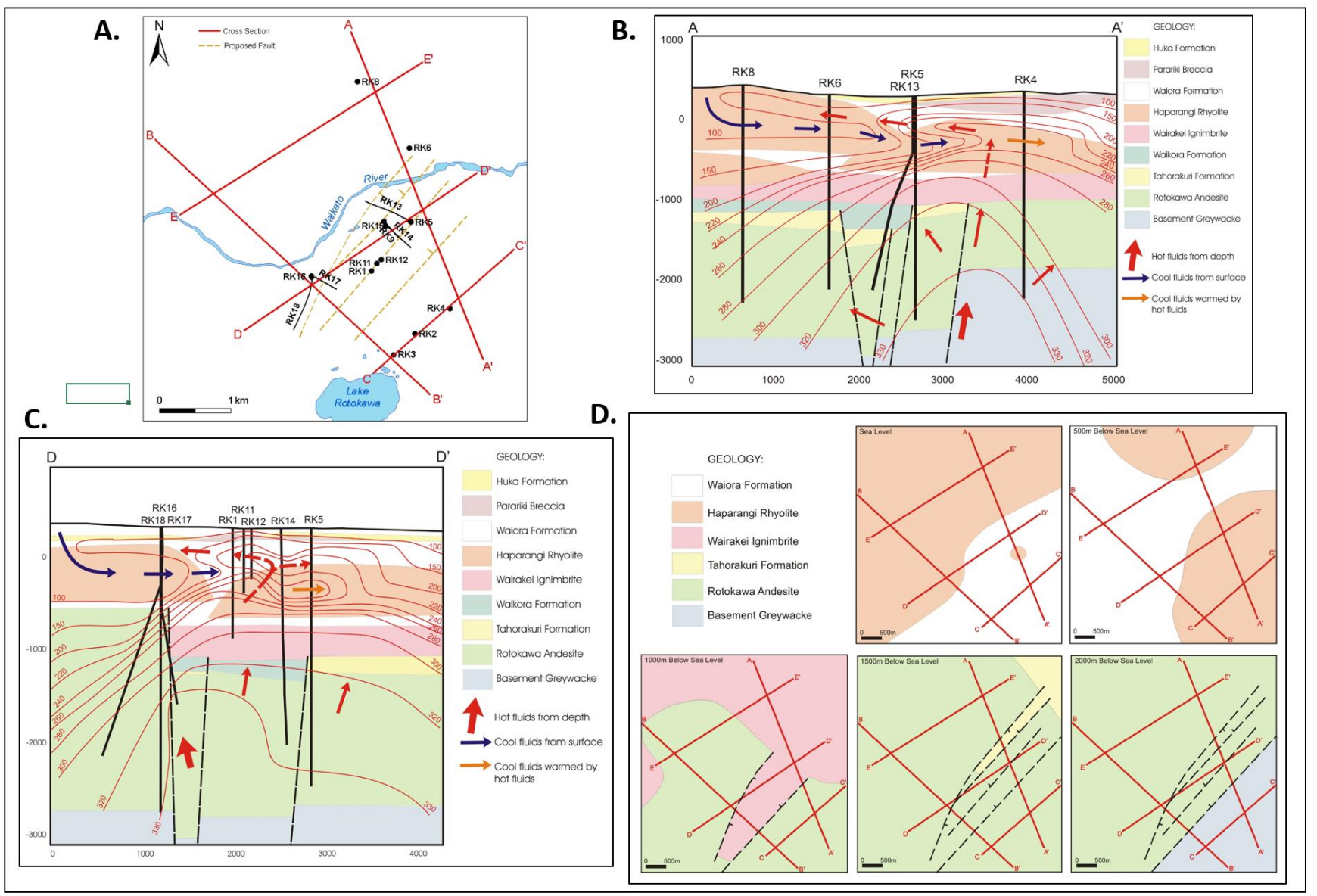

Figure 20: Conceptual model that the Rotokawa system model is based. A. Orientation of cross sections lines used in development of the conceptual model. Three major field faults are shown at the top of the Rotokawa Andesite. B. Cross section

A-A' of the Rotokawa conceptual model. The cross section showing well tracks, geology, faults and natural state isotherms temperatures (in degree $C$ and meters bsl). C. Cross section D-D' of the Rotokawa conceptual model showing well tracks, geology, faults and natural state isotherms temperatures (in degree C and meters bsl). (Bowyer and Holt 2010). D. Geological maps at sea level and 500m, 1000m, 1500m and 2000m below sea level.

High chloride content in fluid discharged from RK4, with progressive dilution in wells to the north, is consistent with the location of the deep up flow between RK4, 14 and 17, as suggested by natural state temperatures. The injection production and central field fault will extend downward to the modeled intrusive body or BDT. It is reasonable to assume the injection and central field fault are the primary path way of upwelling hot fluid. Fluids in the andesite-hosted geothermal reservoir follow a preferred SW-NE flow direction, and outflow to the north and northeast. There is also evidence to suggest the central field fault acts as a flow barrier perpendicular to the SW-NE (Bowyer and Holt 2010).

Cool inflows from the surface extend across the area at depths up to $500 \mathrm{~m}$ below sea level, flowing primarily through Haparangi Rhyolite lavas and breccias and potentially preferentially favoring boundaries between lava flows. These cool inflows remain separate from the deeper geothermal reservoir due to the occurrence of the largely impermeable Wairakei Ignimbrite which acts as a cap to the reservoir. 
Shallow pressures were seen to be high at the base of the clay-rich Huka Formation, suggesting that this formation is capping the shallow injection aquifer. A tracer test in 2006 identified a SW-NE oriented preferred flow direction in the geothermal reservoir from RK18 to RK17 and RK13. This is consistent with the proposed SW-NE orientation of normal faults as suggested by differing elevations for the top of the Basement Greywacke and Rotokawa Andesite in wells (Bowyer and Holt 2010).

Micro seismic injection from shows. The interpretation for the microseicmic is that the vertical permeability displayed in Swell will terminate at $\sim 3000$ to $\sim 3500 \mathrm{~m}$ depth. The entire simulation matching process will be done deterministically without the use of automatic history matching or inverse modelling techniques.

The field temperature profile can be seen in Figure 21 (Hernandez et al. 2015). This will be used to match natural state temperatures for the field. Individual well PTS (pressure temperature spinner) data is typically held as confidential by the geothermal operating company.

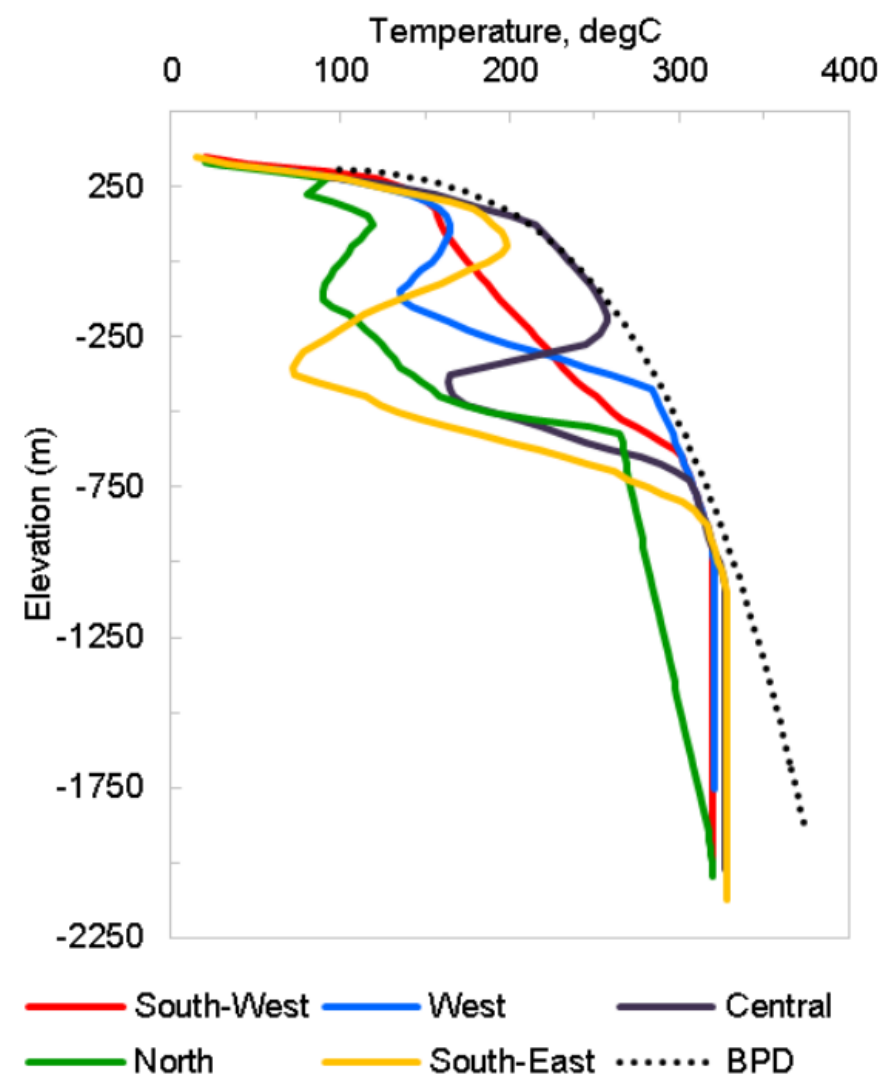

Figure 21:Interpreted natural state temperature in different areas of the Rotokawa reservoir. (BPD = Boiling Point for Depth) (Hernandez et al. 2015)

\section{Deep Conceptual model}

Below the current Rotokawa geothermal system lies the convection system that allows high enthalpy fluid to heat at the BDT and travel upward into the geothermal reservoir. As previously mentioned, an intrusive mama heat source would cool in the order of $\sim 20 \mathrm{kyr}$ due to meteoric water circulation. The conceptual model of the large-scale convection cell will extend from the surface downward to the BDT. 
Meteoric water be primary flowing into the geothermal system from outside the Rotokawa field from the North-West and South East. Elevation will also be incorporated into the model and may play a factor in driving downflow and the outflow in shallow depths where permeabilities are high in unconsolidated breccias. The BDT at the bottom of the model will represent a no flow boundary with a fixed temperature. It will be assumed that the permeable fractures of the greywacke will begin to reduce as the rock becomes ductile at these temperature and conductive heating will dominate heat flow. The temperature will be a fixed to at constant temperature. Previous modeling of the TVZ (Ratouis and Zarrouk 2015, Pearson 2017 and Kaya et. al 2014) used heat flow at the bottom of the model. Previous reservoir models. However, reservoir models typically use a fixed mass flow injection into the bottom of the model in addition to a fixed temperature base (Boyer and Holt 2012, Hernandez et al. 2015). The concept of this model being that the temperature of the system will be set at the BDT and that's when we assume no flow will occur.

Although these models suggest the presence of partial melts at shallow depth $(5-4.5 \mathrm{~km})$ with interstitial highly conductive hypersaline brine, no evidence of magmatic input is observed in term of metal zoning (eg. $\mathrm{Zn}$ ) from the intrusion to the surface (Chambefort and Dilles, 2017). Normally, Cl-bearing brines are rich in metals which form a zonation in precipitates while the host fluids are rising toward the surface, as has been observed in the Ngatamariki fossil hydrothermal system (Chambefort et al., 2017). Additionally, high gas systems such Rotokawa have no chemical sign of actively degassing shallow intrusions, despite the enrichment in gas (appendix C.1.4.) (Chamberfort et al. 2017), again suggesting no close source of partial melt as the non-condensable gases are not sourced from a local magmatic body.

Additionally, Geophysical studies show that the aseismic zone in the central TVZ is likely below $6 \mathrm{~km}$ depth where the brittle-ductile transition is located (Sherburn et al., 2003; Stern et al., 2010; Bannister et al., 2016). The aseismic zone can be seen as seismicity events decrease from $6 \mathrm{~km}$ and deeper Figure 22). Investigating the focal depths of intraplate earth quakes, Chen and Molnar 1983 show that crustal seismicity is limited to temperature below 250-450C ${ }^{\circ}$, Consistent with Burgmann and Dresen (2008) who suggest that in continental rocks the brittle ductile transition occurs within the temperature range 300$500 \mathrm{C}^{\circ}$ and with Geothermal drilling results that indicate the transit occurs at $370-400 \mathrm{C}^{\circ}$ (Fournier 1999). 


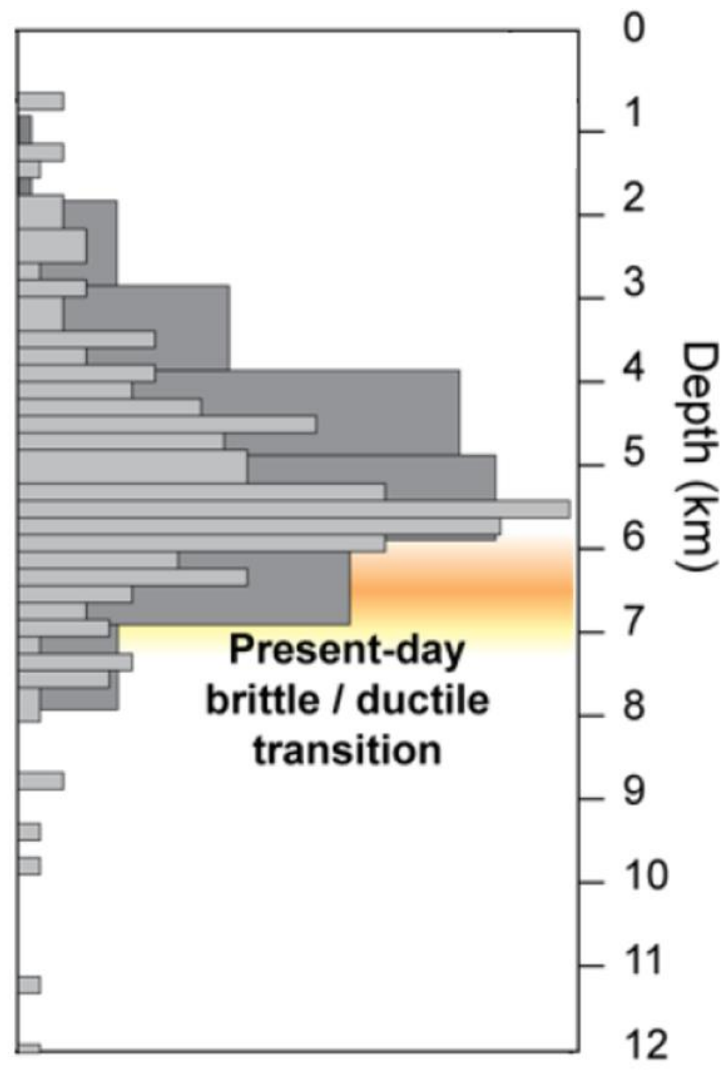

Seismic event count

Figure 22: Present-day seismic events in function of depth from Sherburn et al. (2003) and Bannister et al. (2016). Figure from Chambefort et al. 2017.

The combination of both these factors makes it seem unlikely that there is a body of shallow partial melt below Rotokawa as suggested in Bertrand et al. 2015. It will be assumed in this model at the base of seismicity lies the BDT and the temperature of this may be between 400-450C. The no flow BDT boundary will be set $-6000 \mathrm{mRSL}$ elevation and the temperature will be simulated between 400 and 450 ${ }^{\circ} \mathrm{C}$. The deep conceptual model shown in Figure 23 is a modified figure from Wilson and Rowland, 2016. The location of the cross section can be seen form the residual gravity map on in appendix C.1.5. 


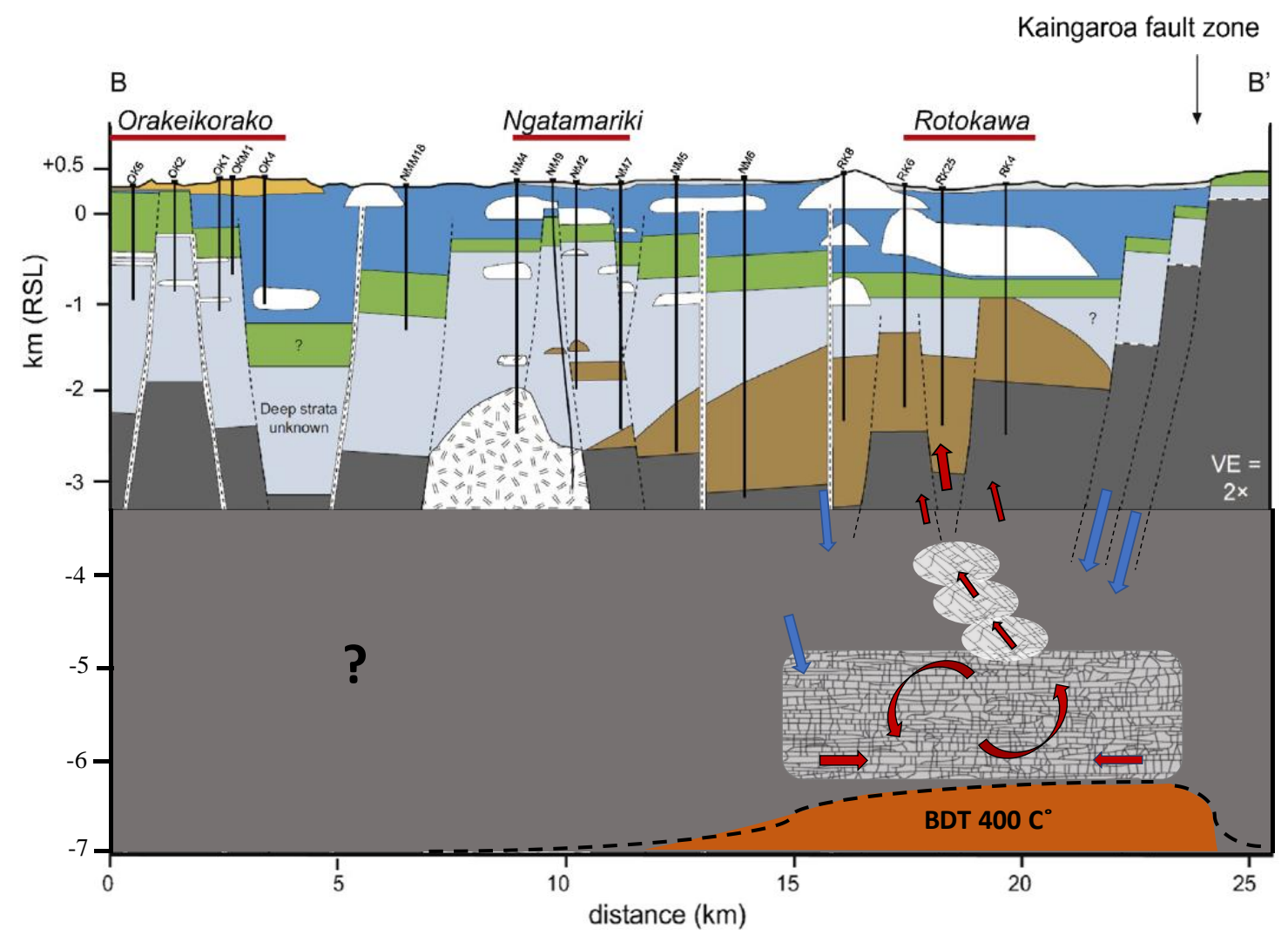

Figure 23: Modified conceptual model of from Wilson, Rowland 2016 showing convection heat source conceptual model for Rotokawa field heat source. Downflow through faulted and fractures zones to the SE and NW of the TVZ. Blue arrows indicated cool meteoric water with red indicating heated the heated meteoric water. A high temperature convection cell penetrated by field faulting to allow large upflow into the Rotokawa reservoir.

In general, conceptually the permeability will decrease with depth. The idea being that formations closer to surface have had more time to allow geologic processes to uplifted, fault, deformed the rock and provide additional fracture permeability additionally there is less overburdened stress that may reduce fracture volume.

\section{Creating the Numerical Model}

Over the past two decades, numerical reservoir simulation has become a predominant method by which geothermal reservoirs are analyzed and predictions are made about their future state and performance (O'Sullivan 2000). Comprehensive multi-disciplinary conceptual models integrate natural state temperatures, geology, geophysics, geochemistry, reservoir tracer test results and downhole pressures into a complete geoscientific description of the resource.

The next step in creating the Rotokawa numerical model was to convert the conceptual model as described above, into the digital format required by the TOUGH2 reservoir simulator. The conceptual models are built in QGIS (an open source geographic information system software) as a two-dimensional geologic map spatially assigned. Each layer represents a geologic map at an elevation in meters relative to sea level (mRSL). appendix B.1.1 shows each layer of the model. 
The geologic rock types from the conceptual model are assigned properties in an excel spread sheet. The Spread sheet contains all of the parameters for the TOUGH2 input file. Boundary conditions, layers, simulation parameters, rock types, sources and sinks are all listed in the spread sheet. Rock type properties are based off geology, geophysics, geochemistry, tracer test results and downhole pressure and temperature data when available.

The model grid is the third component needed to create the TOUGH2 input file and is created using a Python code. The grid size area should convert the entire geothermal system and is centered around the Rotokawa geothermal system. The number of cell blocks is easily calculated by multiplying the number of layers give the number of grid blocks. The number of cell blocks is a balance of computational time and resolution. Models with less cells will run faster and take significantly less computational power.

A pytough code is used to divide the geologic map into cell block and assign a spatial location based off the location of the rock type in the layer that was created in GIS the layers can be seen in appendix B.1.2. There is a separate spatialite layer in GIS for each model layer (appendix B.1.3). The rock properties, initial conditions, boundary conditions, sources/sinks and simulation parameters are taken from an excel spread sheet (appendix B and written into a TOUGH2 input file and initial conditions file (INCON). Using these two files the TOUGH2 program can be used to simulate to the natural state.

Adjustments are then made to boundary conditions, rock properties, sources and sinks to obtain and the process is repeated iteratively to obtain until a suitable match is obtained. The model was manual matched and no inverse modeling was used and only single porosity modeling will be used similar to modeling by Kaya al 2014 and Pearson et al. 2017.

Rotokawa Geothermal System Model

The Rotokawa will incorporate the aspects of the study area, related geothermal reservoir modeling work, to create the conceptual model into a numerical TOUGH2 model. Note that the geothermal operator did not release induvial well data so matching will be done from published literature.

The grid area will be based off MT from Bertrand et al. 2015. The reservoir will be defined and modeled from temperature contour, temperature profiles, and will be based off previous reservoir modeling well as previous reservoir modeling. Because the MT surveys extend a much larger area than a typical reservoir model the cell block sizes will have to be larger than in a typical geothermal reservoir model. Additionally, the vertical layers will also be much larger as the model will extend to the brittle ductile transition.

Grid and Layering

The numerical model covers an area of 20 by $10 \mathrm{~km}$ and is centered on the Rotokawa steam field. The model grid was rotated 45 deg to the NW to allow the $x$ and $y$ axis of the model to lie relatively parallel to SW-NE strike of the fault structure of the Rotokawa field as described in the conceptual model and study area. as reported in the conceptual model. The model contains 20 layers extending from $350 \mathrm{mRSL}$ (ground level) to $6000 \mathrm{~m}$ below sea level (assumed BDT). Each layer contains 2880 blocks and 5652 connections, for a total of 57,600 grid blocks in the computational grid. The specific elevation and thickness of each layer can be seen in appendix B.1.1. The center grid block starts at 50x50m and increases to $1000 \times 1000 \mathrm{~m}$ at the corners. The grid can be seen overlain by the $-6500 \mathrm{~m}$ MT resistivity from Bertrand et al. 2015 in Figure 24. 


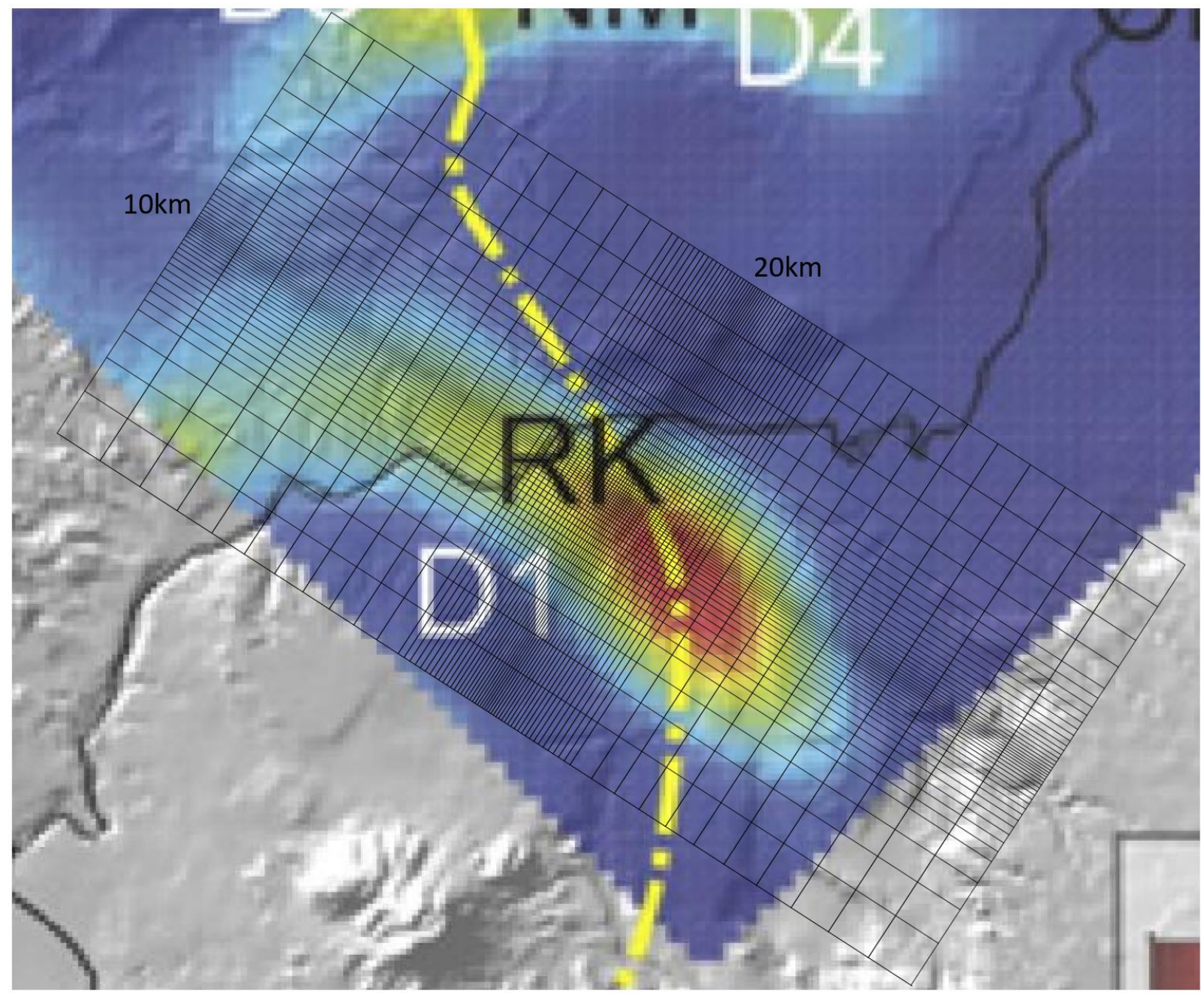

Figure 24: RK38 grid overlain -6500m MT resistivity from Bertrand et al. 2015.

A single porosity model is used, because simulations are simulated to natural state conditions run over hundreds of thousands of years a dual and single porosity will result. In a fracture dominated system such as Rotokawa a dual porosity models will almost always be used in a commercial reservoir model. This is because a dual porosity MINC model will better represent temperature and pressure in a reservoir production time scale. Since this reservoir model will be run to natural state the difference will be negligible and a Single porosity model will decrease computational time and simplify the modeling process. Single porosity modeling was done in both Kaya et al. 2014 and Pearson et al. 2017. Known faults and fractured zones are will be given a higher bulk permeability in this model.

The resistivity structure within the brittle upper crust indicates rising, narrow plumes of hot water beneath some of the geothermal fields (Bibby et al., 1995; Heise et al., 2010; Bertrand et al., 2012) this is used for the basis of the permeability structure $\backslash$ below the Reservoir. Higher restivity will be assumed to have a larger convection rate of saline fluid and will be designated a higher permeabilities. To keep the permeability structure simple restivity contours will be used from Bertrand 2015 to assign rock properties to the model higher restivity will be assigned slightly higher permeabilities. 


\section{Boundary Conditions}

All model boundaries are no flow at the sides and bottom of the model. The bottom was given initially set to 415 and $375 \mathrm{C}$ as shown in Figure 25 . The rock was given a specific heat of $1 \mathrm{E} 30 \mathrm{~J} / \mathrm{kg}{ }^{\circ} \mathrm{C}$ making the bottom layer a fixed temperature. There is no heat or mass injection into the bottom of the model as the bottom of the model will represent a no flow brittle ductile transition boundary. The top boundary is a fixed temperature and pressure to represent atmosphere at 1 bar and $20^{\circ} \mathrm{C}$. The is a fixed mass injection into the second layer of the model to resent rainfall of 1 meter per year and an infiltration rate of $5 \%$ giving an injection evenly distributed over the model of $400 \mathrm{~kg} / \mathrm{s}$.

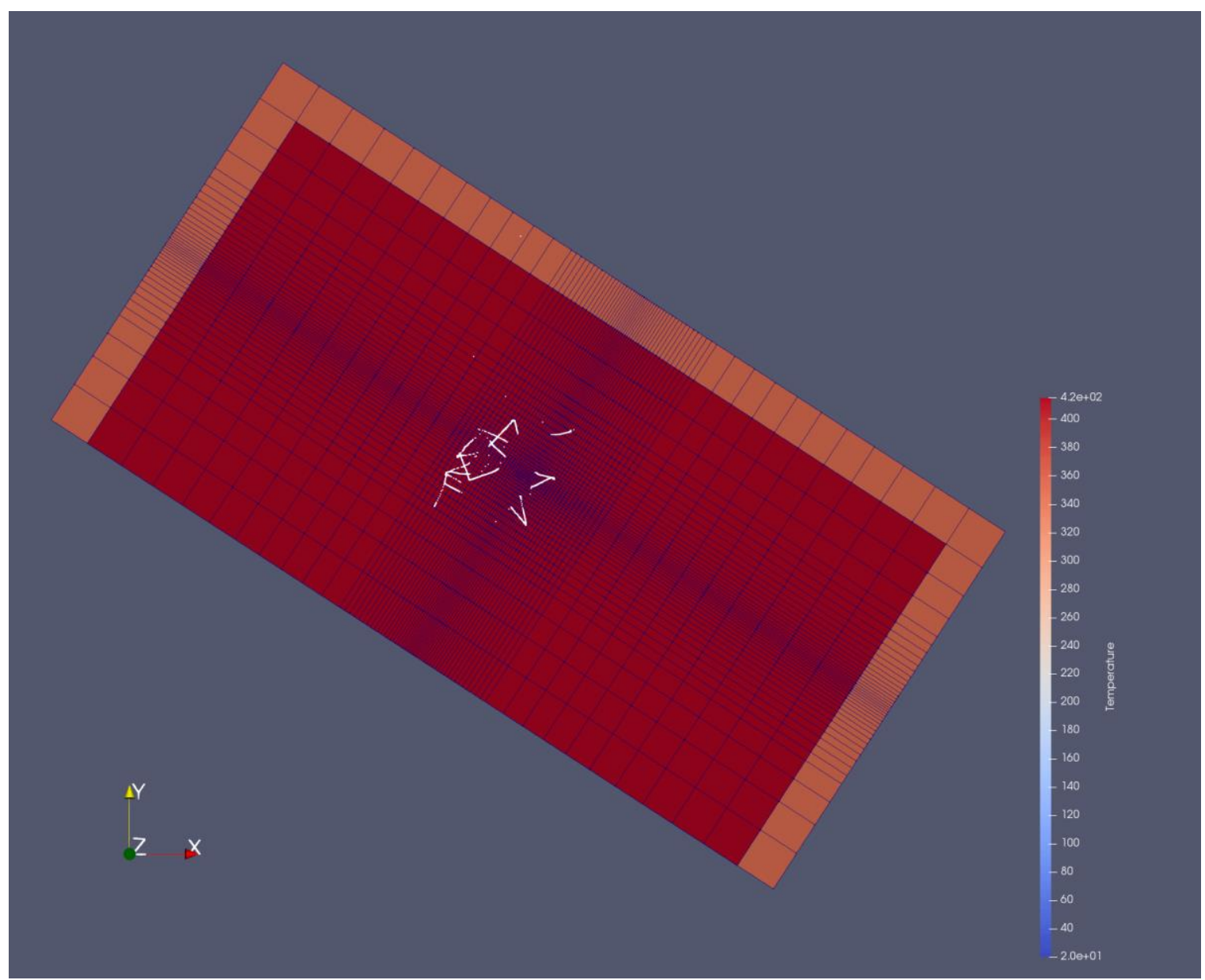

Figure 25: A vertical temperature slice of the RK38 model at -6000mRSL. The grid and Rotokawa well tracks shown in white. This is the bottom layer in the model a fixed temperature no flow boundary.

\section{Model Permeability}

No permeability data was given from the geothermal operating company. This makes modeling within the reservoir tricky. The objective of the model is not to history match individual well data only to match natural station conditions of the reservoir. Convection vs conduction profiles for each region of the reservoir well from the pressure and temperature profiles can give an indication of permeability. Only a single porosity model will be used for simplicity similar to previous TVZ scale models that were run to natural state conditions. 
The from the conceptual the fault permeability will extend to $-3500 \mathrm{mrs}$ where MEQ events terminate (Swell et. al 2015). Below -3500mRSL the MT inversion from -1500 will be used to estimate permeability. The lower restivity will be assumed to be convecting and saline fluid a higher permeability will allow a greater mass flow rate. A $3 \Omega \mathrm{m}$ and a $5 \Omega \mathrm{m}$ contour will be used taken from each depth slice for Figure 12. Both the contours will have a higher vertical permeability than the background rock. The lower restivity $3 \Omega \mathrm{m}$ contour will have the highest vertical permeability. Two faulted areas outside of the reservoir to the north west and south-east will also have higher vertical permeability in comparison to the background rock and meteoric downflow into the system.

\section{Fault Process Model}

A process model is built to isolate and test a component of a larger reservoir model. In this case a fault process model will be built to do sensitivity analysis how rock properties in TOUGH2 effect the amount of energy, mass flow, enthalpy and temperature that a fault can convert vertically. The variables that will be tested in the process model are given in Table 2 below. The fault represents a permeable vertical path way for fluid to travel into the reservoir. Ensuring the right mass flow rate, and fluid enthalpy will be essential to matching the Rotokawa natural state temperature and pressure.

\begin{tabular}{|c|c|c|c|c|c|c|c|c|c|c|}
\hline \multicolumn{11}{|c|}{ Variables of Single Fault Process Model } \\
\hline $\mathrm{mD}$ & $\mathrm{mD}$ & $\mathrm{mD}$ & $\%$ & $\mathrm{~W} / \mathrm{m}^{\circ} \mathrm{C}$ & $\mathrm{km}^{2}$ & $\%$ & $\mathrm{~kg} / \mathrm{m}^{3}$ & $\mathrm{~J} / \mathrm{kg}{ }^{\circ} \mathrm{C}$ & $\mathrm{km}$ & $\mathrm{mRSL}$ \\
\hline 10 & 5 & 20 & 10 & 3 & 16.6 & 20 & 2700 & 1000 & 7.6 & -6000 \\
\hline 100 & 20 & 200 & 20 & 5 & 36.52 & 30 & 3200 & 1200 & 10.2 & -5000 \\
\hline \multirow[t]{2}{*}{1000} & 100 & 1000 & & & & 40 & & & 13.1 & -4500 \\
\hline & & & & & & & & & 16.6 & -4000 \\
\hline
\end{tabular}

Table 2:Variables being tested for the single fault process model.

The fault in this scenario will be a $20 \mathrm{~m}$ wide and $\sim 16 \mathrm{~km}$ straight zone. The objective will be to compare temperatures and to the vertical mass flow from changes to the rainfall, hot plate depth as well as the fault permeability, $\mathrm{K}_{\mathrm{v}} / \mathrm{k}_{\mathrm{h}}$, porosity, density, specific heat, conductivity, length, and area.

\section{Grid and Layering}

An $18.5 \mathrm{~km} \times 4.8 \mathrm{~km}$ logarithmic grid was used with the inner most grid being $20 \mathrm{~m} \times 20 \mathrm{~m}$ an increasing in size outward in both the $y$ and $x$ direction. One layer of the gird is 1968 blocks and 3830 connections. There were 22 layers from $-8000 \mathrm{~m}$ to $300 \mathrm{mRSL}$ so the computational grid has 43,296 cell blocks with 127,556 connections. The grid layer elevation and thickness can be seen in appendix B.2.1..The fault is shown by the red line in Figure 26 below, and represents the inner 2 cell blocks in width extending the length of the grid. 


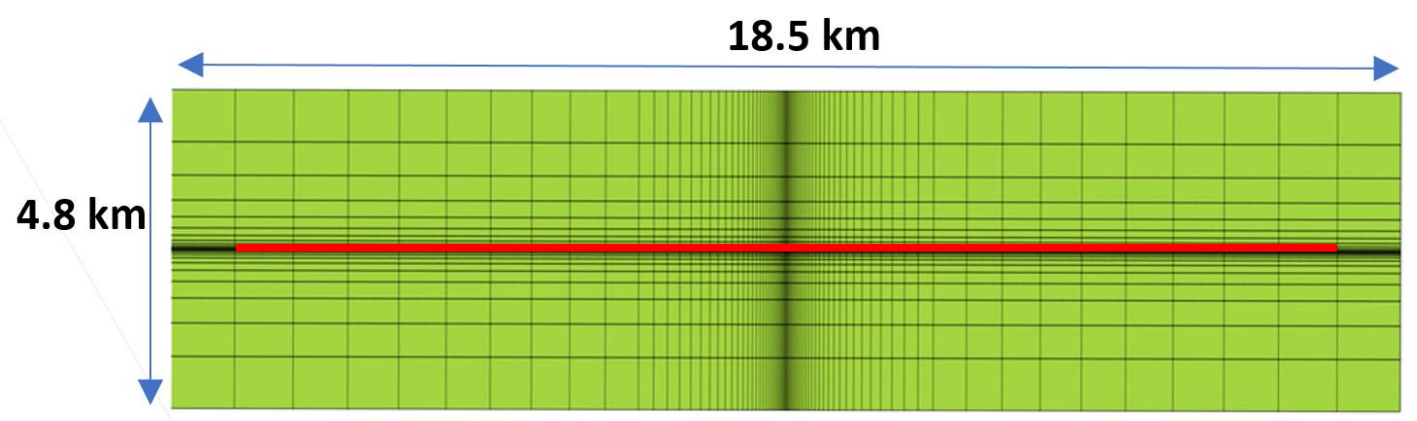

Figure 26: Fault process model grid of $1968 \mathrm{grid}$ blocks. The grid is $18.5 \mathrm{~km}$ to $4.8 \mathrm{~km}$ ranging from $10 \mathrm{~m}$ to $780 \mathrm{~m}$ in the $\mathrm{x}$ direction and 10 to $950 \mathrm{~m}$ in the $y$ direction.

\section{Boundary conditions}

The model is dimensions $18.5 \mathrm{~km} \times 4.8 \mathrm{~km} \times 8.3 \mathrm{~km}$. The top of the model has a fixed temperature and pressure air boundary with a porosity of $0.9,1$ bar pressure, and $0.3 \mathrm{~W} / \mathrm{m}^{\circ} \mathrm{C}$ conductivity. The no flow can occur from edges of the model. The bottom layer is given a $1 \mathrm{E} 30 \mathrm{~J} / \mathrm{kg}{ }^{\circ} \mathrm{C}$ specific heat to create a fixed temperature boundary. The model was fixed at $400{ }^{\circ} \mathrm{C}$. The edge cell block was fixed at $200{ }^{\circ} \mathrm{C}$ to ensure no upward flow at the edges of the model. A constraint mass injection of $20^{\circ} \mathrm{C}$ water is input into the top of the model to simulate the rainfall.

\section{Rock Parameters}

Five different rock parameters were assigned to the fault block model. The rocks types are soil, clay cap, hole in cap, volcanic infill, basement greywacke and altered basement greywacke the assignment at each layer with the rock parameters in Table 3.

Geologic Zone Parameters Single Fault Model

\begin{tabular}{|c|c|c|c|c|c|}
\hline \multirow[t]{2}{*}{ Elevation (mRSL) } & \multirow[t]{2}{*}{ Description } & \multicolumn{3}{|c|}{ Permeability $\left(\mathrm{m}^{2}\right)$} & \multirow[t]{2}{*}{ Porosity } \\
\hline & & $x$ & $y$ & z & \\
\hline 300 to $0 \mathrm{~m}$ & Soil/Aquifer & $1.00 \mathrm{E}-13$ & $1.00 \mathrm{E}-13$ & $1.00 \mathrm{E}-13$ & 0.20 \\
\hline 0 to $-500 m$ & Clay Cap & $1.00 \mathrm{E}-18$ & $1.00 \mathrm{E}-18$ & $1.00 \mathrm{E}-18$ & 0.01 \\
\hline$-500 m$ & Hole in Cap & $1.00 \mathrm{E}-18$ & $1.00 \mathrm{E}-18$ & $1.00 \mathrm{E}-15$ & 0.20 \\
\hline$-500 m$ to $-2500 m$ & Volcanic Infill & $5.00 \mathrm{E}-16$ & $5.00 \mathrm{E}-16$ & $1.00 \mathrm{E}-16$ & 0.10 \\
\hline-2500 to $-3500 m$ & Basement Greywacke & $5.00 \mathrm{E}-18$ & $5.00 \mathrm{E}-18$ & $1.00 \mathrm{E}-18$ & 0.05 \\
\hline-3500 to -8000 & Basement Greywacke? & $5.00 \mathrm{E}-19$ & 5.00E-19 & $1.00 \mathrm{E}-19$ & 0.03 \\
\hline-500 to $-8000 m$ & Fault & & Variable & & 0.10 \\
\hline
\end{tabular}

Table 3: Rock parameters for the single fault process model.

The following rock parameter are the same between all the layers unless it is the variable being tested. The conductivity is $2.20 \mathrm{~W} / \mathrm{m}^{\circ} \mathrm{C}$, the densities are $2700 \mathrm{~kg} / \mathrm{m}^{3}$ and specific heat off all rocks are $1000 \mathrm{~J} / \mathrm{kg}$ ${ }^{\circ} \mathrm{C}$. Limitations with this fault model are the lack of dip in the fault. Largely due to the large $z$ block size. The grid size can be seen in relation to the Rotokawa and adjacent geothermal fields in Figure 24 . The base case has a fault permeability of $1.00 \mathrm{E}-14 \mathrm{~m}^{2}$ in the $\mathrm{x} y$ and $\mathrm{z}$ direction as seen in Table 4. 
Table 4 shows the single fault model base case parameters that all of the changes were compared against. The base case represents a middle case that all the of the independent variable tests can be compared against.

\begin{tabular}{|c|c|c|c|c|c|c|c|c|c|}
\hline \multicolumn{10}{|c|}{ Single Fault Process Model Base Case } \\
\hline $\begin{array}{l}\text { Permeability } \\
(\mathrm{mD})\end{array}$ & $\begin{array}{l}\text { Vertical } \\
\text { Perm } \\
(10 \mathrm{mD})\end{array}$ & $\begin{array}{l}\text { Infiltration } \\
\text { Rate (Rainfall) }\end{array}$ & $\begin{array}{l}\text { Fault } \\
\text { Conductivity }\end{array}$ & $\begin{array}{l}\text { Fault } \\
\text { Area }\end{array}$ & $\begin{array}{l}\text { Fault } \\
\text { Porosity }\end{array}$ & $\begin{array}{l}\text { Fault } \\
\text { Rock } \\
\text { Density }\end{array}$ & $\begin{array}{l}\text { Fault } \\
\text { Rock } \\
\text { Specific } \\
\text { Heat }\end{array}$ & $\begin{array}{l}\text { Fault } \\
\text { Length }\end{array}$ & $\begin{array}{l}\text { Hot } \\
\text { Plate } \\
\text { Depth }\end{array}$ \\
\hline $\mathrm{mD}$ & $\mathrm{mD}$ & $\%$ & $\mathrm{~W} / \mathrm{m}^{\circ} \mathrm{C}$ & $\mathrm{km}^{2}$ & $\%$ & $\mathrm{~kg} / \mathrm{m}^{3}$ & $\mathrm{~J} / \mathrm{kg}{ }^{\circ} \mathrm{C}$ & $\mathrm{km}$ & $\mathrm{mRSL}$ \\
\hline 10 & 10 & 5 & 2.2 & 3.32 & 10 & 2700 & 1000 & 16.6 & -8000 \\
\hline
\end{tabular}

Table 4: Single fault process model base case parameters.

\section{Chapter 5: Modeling Results}

\section{Fault Process Model}

The fault process primary looked at the factors effect heat flow and convection of a model based around a single fault convection from -8000 mRSL to surface across a deep flow layer (-6000) and a shallow level $(-1000 \mathrm{mRSL})$. Factors that and patterns observed in the fault process model can be carried into the large scale Rotokawa Geothermal System Model to help match natural state conditions. All of the variables that were tested are shown in Table 2.

Energy flow and enthalpy were also calculated but since the system is entirely compressed liquid and purely water the enthalpy can be taken directly from a steam table given the temperature and pressure. Similarly, the energy flow from conduction is negligible when compared to the heat from convection in the fault so within the fault the energy flow is approximately

$$
\text { Energy Flow } U p \approx \text { Flowrate } U p * \text { Fluid Enthlapy }
$$

So, displaying the enthalpy and energy flow will display the exact same relationships as temperature and mass flow. For simplicity only, the temperature and mass flow changes will be shown as these are the parameters that are going to be matched in the This relationship can be observed in Figure 32 and Figure 33 below the flow rate and energy flow are directly correlated for both layers.

\section{Sensitivity Analysis}

Fault permeability, $\mathrm{k}_{\mathrm{v}} / \mathrm{k}_{\mathrm{h}}$, porosity, density, specific heat, conductivity, length, area, rain fault rate and hot plate depth will undergo a sensitivity analysis using the fault process model to see what variable impacts the temperate and up flow rates. The flow and temperature across the $-1000 \mathrm{mrs}$ level will indicate how parameters affect the mass flow and temperature at a shallower zone in the system while flows across the $-6000 \mathrm{mRSL}$ layer will indicate parameters effecting the deeper convection.

A tornado plot shows the deviation from the base case for both temperature and up flow as a variable is tested a range of values. The larger the bar the more variation occurred between the min, max and base case. Blue indicates a decrease from the base case and orange shows an increase from the base case. The $-1000 \mathrm{~m}$ base case shown resulted in fluid a temperature of $272^{\circ} \mathrm{C}$ and an upflow rate of $18.2 \mathrm{~kg} / \mathrm{s}$. The $-6000 \mathrm{~m}$ base case had a temperature of. $313 \mathrm{C}^{\circ}$ and $20.2 \mathrm{~kg} / \mathrm{s}$. 
At $-1000 \mathrm{mRSL}$ the fault permeable was the most sensitive parameter affecting the fault temperature followed by the vertical permeability and the fault length shown in Figure 27 below. The total range of fault temperatures ranged from 88 to $298 \mathrm{C}^{\circ}$. In all the scenarios the temperature was lower than the base case the exception being when the hot plate depth was brought shallower. Infiltration rate, fault conductivity, specific heat, rock density and porosity did not have a significant impact on the fault temperature. The highest temperature was a result of the shallowest hot plate depth at $-4000 \mathrm{mRSL}$. And the lowest temperature was a result of the fault permeability being reduced to $1 \mathrm{mD}$.

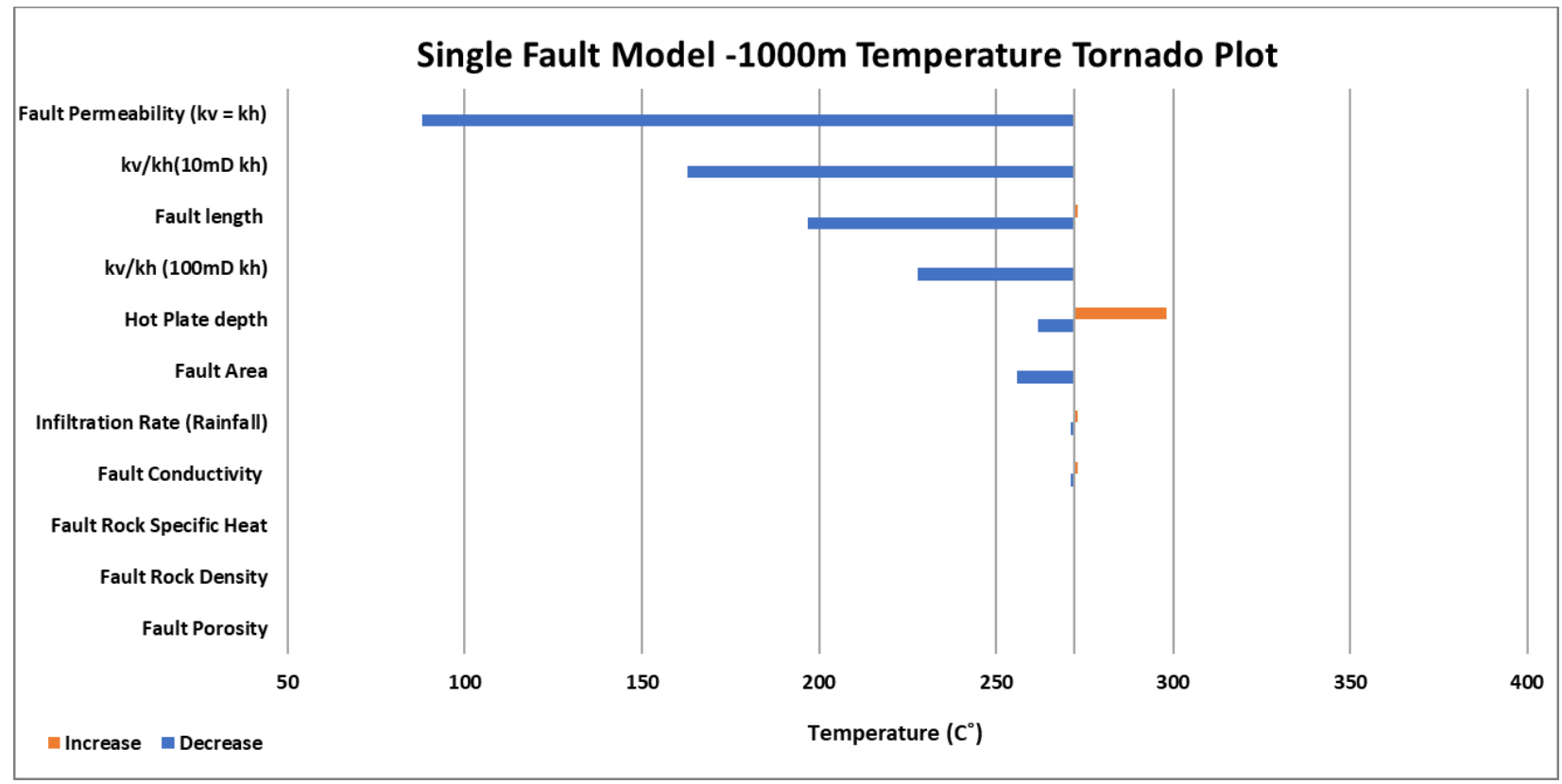

Figure 27: Tornado plot of the single fault model at -1000m showing parameters impact on convection fluid temperature.

At $-1000 \mathrm{mRSL}$ fault area had the largest effect on the mass flow followed by fault permeability and fault vertical permeability. Mass up flow rates ranged from 0.3 to $107.2 \mathrm{~kg} / \mathrm{s}$ shown in Figure 28 below. Infiltration rate, fault conductivity, specific heat, rock density and porosity did not have a significant impact on the mass up flow rate. The highest mass flow rate was achieved in the $36.5 \mathrm{~km}^{2}$ fault model and the lowest mass flow rate was again a result of the $1 \mathrm{mD}$ fault. 


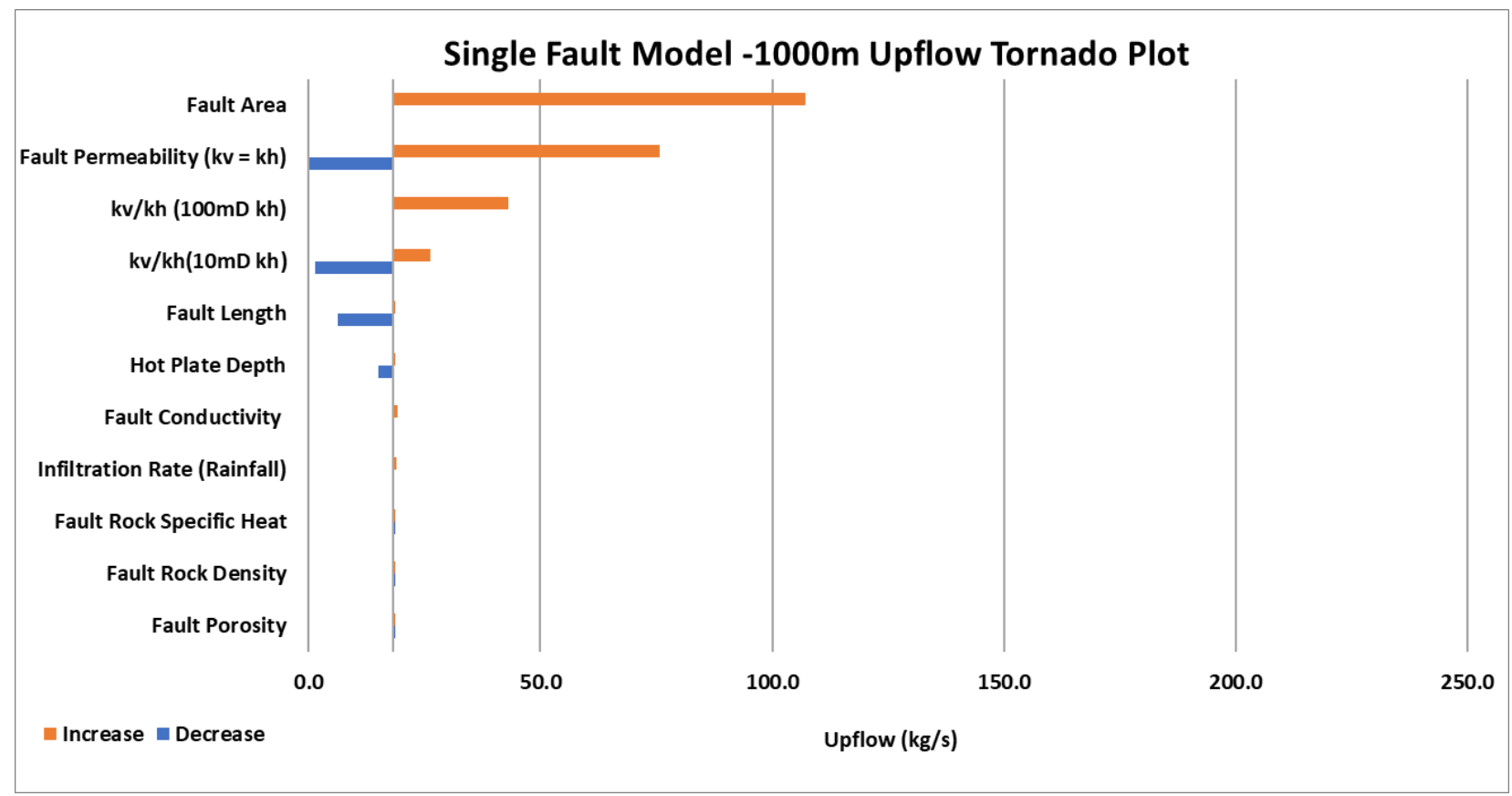

Figure 28: Tornado plot of the single fault model at $-1000 \mathrm{~m}$ showing parameters impact on up flow rate

At $-6000 \mathrm{mRSL}$ the fault the temperature ranged from 229 to $354 \mathrm{C}^{\circ}$. Fault permeability and fault vertical permeability for both the 10 and $100 \mathrm{mD}$ fault were the most sensitive parameters as seen in Figure 29 below. Infiltration rate, fault conductivity, specific heat, rock density and porosity did not have a significant impact on the fault temperature at $-6000 \mathrm{~m}$. The highest temperature a fault with a $10 \mathrm{mD} \mathrm{k}_{\mathrm{h}}$ and $1 \mathrm{mD} \mathrm{kv}$. The lowest temperature was the $100 \mathrm{mD} \mathrm{k}_{\mathrm{h}}$ and $1000 \mathrm{mD} \mathrm{k}_{\mathrm{v}}$ but the $1000 \mathrm{mD}$ fault was also lower than the base case.

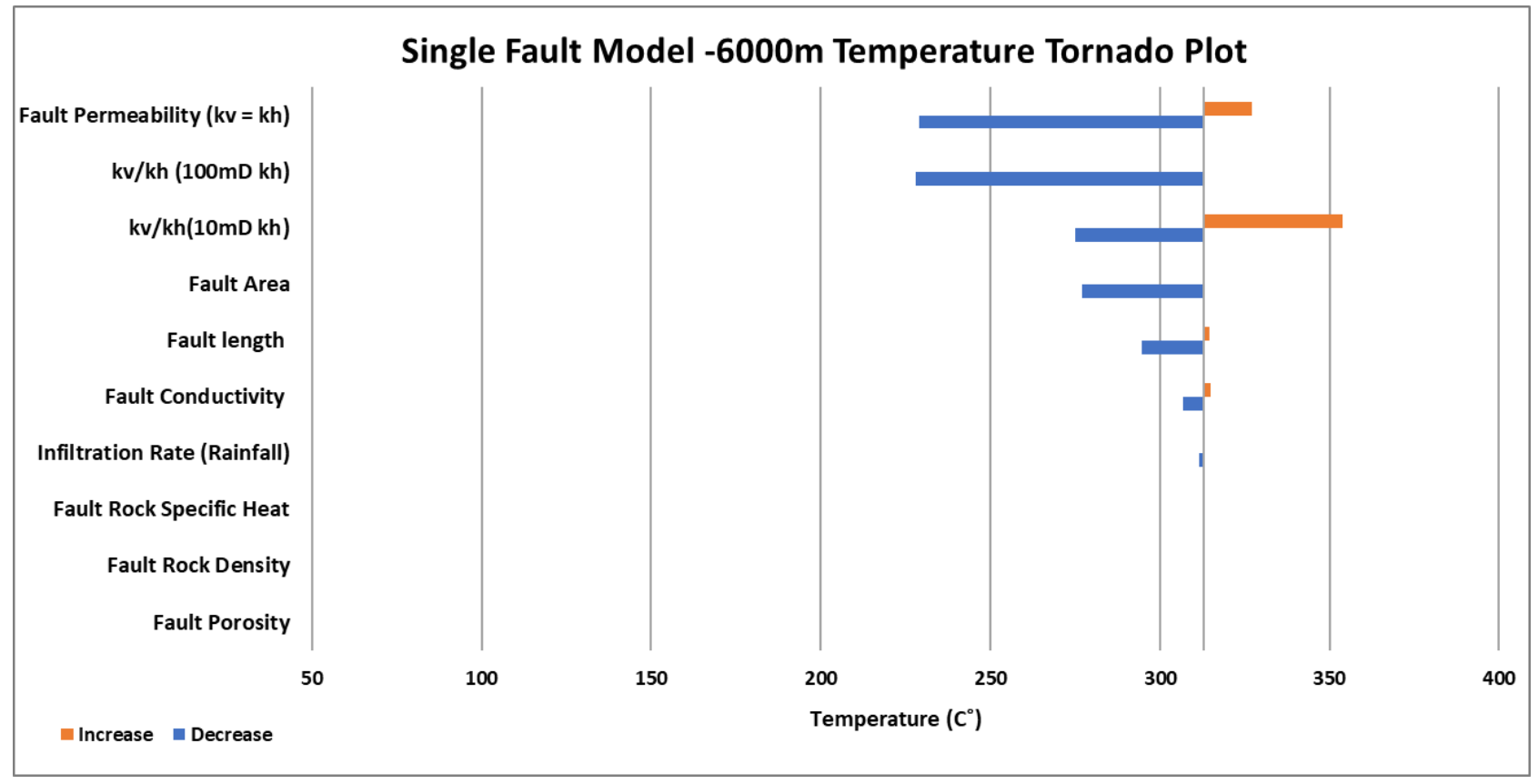

Figure 29: Tornado plot of the single fault model at $-6000 \mathrm{~m}$ showing parameters impact on up flow rate across $-6000 \mathrm{mRSL}$. 
Mass flow across $-6000 \mathrm{mRSL}$ varied the most with vertical permeability of the $100 \mathrm{mD}$ fault, fault permeability and fault area. Again, rainfall specific heat, rock density and porosity did not have an effect on the mass flow rate. The mass flows ranged significantly from $210 \mathrm{~kg} / \mathrm{s}$ to $\sim 0 \mathrm{~kg} / \mathrm{s}$. The largest mass flowrates across $-6000 \mathrm{~m}$ was in the $100 \mathrm{mD} \mathrm{k}_{\mathrm{h}}$ and $1000 \mathrm{mD} \mathrm{k}_{\mathrm{v}}$ model. The lowest mass flow rate was the lowest permeability fault $(1 \mathrm{mD})$ fault.

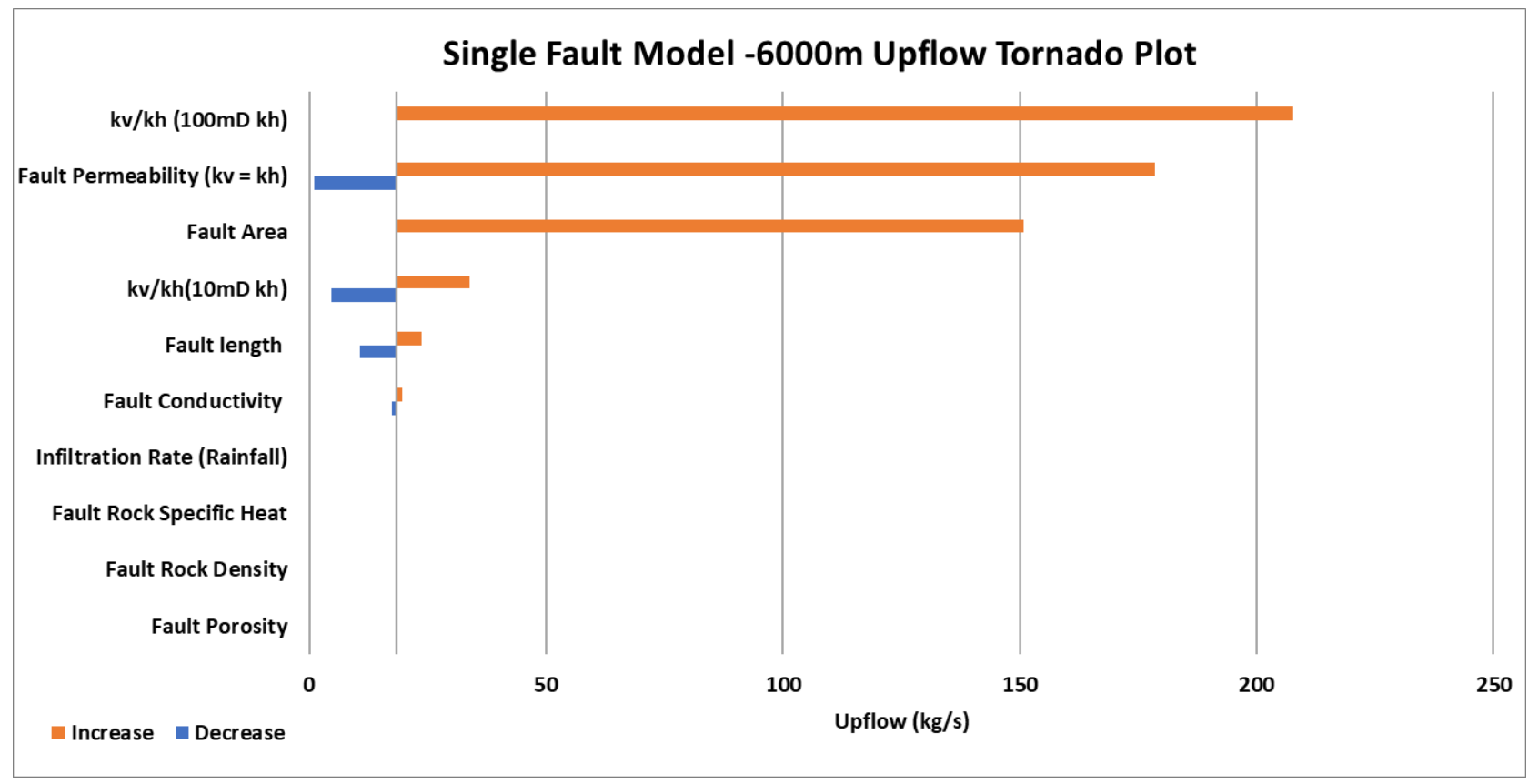

Figure 30: Tornado plot of the single fault model at $-6000 \mathrm{~m}$ showing parameters impact on up flow rate.

The deep convection model shows that temperature is most sensitive to permeability and the vertical to horizontal permeability ratio. The highest temperature has low vertical permeabilities. The mass up flow is most sensitive to the vertical to horizontal permeability ratio $\left(k_{v} / k_{h}\right)$, the higher permeability fault, and the fault area.

In all the models the rainfall infiltration rate, rock specific heat, fault density, and fault porosity did not have a significant impact on the systems mass flow or fluid temperature.

The flows across -1000 and -6000 will be evaluated the idea being that the $-6000 \mathrm{~m}$ level will give properties of deep flow and the -1000 RMSL will give an idea of deeper flow. Although the Rotokawa system is not a Single fault sourced system, the current conceptual model has three fault presents in the Rotokawa geothermal system that may allow up flow. Fig 17 shows the maximum fault temperature and enthalpy of fluid within the fault at -1000 and $-6000 \mathrm{mRSL}$.

For the following sensitivities as the flows across a defined level will be assessed. In Figure 31 the $6000 \mathrm{mRSL}$ are represented in cooler colors while the $-1000 \mathrm{mRSI}$ are shown in warmer colors. The fault permeability is simulated at $1,10,100$ and $1000 \mathrm{mD}$, with the $x, y$ and $z$ permeable directions being the same. At $-6000 \mathrm{mRSI}$ the temperature is inversely related to permeability. A decease with an increase in permeability and the permeability is proportional to the upward mass flow. For -1000mRSL the same relationship occurs above $10 \mathrm{mD}$ but the temperature is lower at $1 \mathrm{mD}$ than $10 \mathrm{mD}$ this is likely because 
the $1 \mathrm{mD}$ limits the upward convection at this distance. At both depths an increase in permeability increases the mass flow rate.

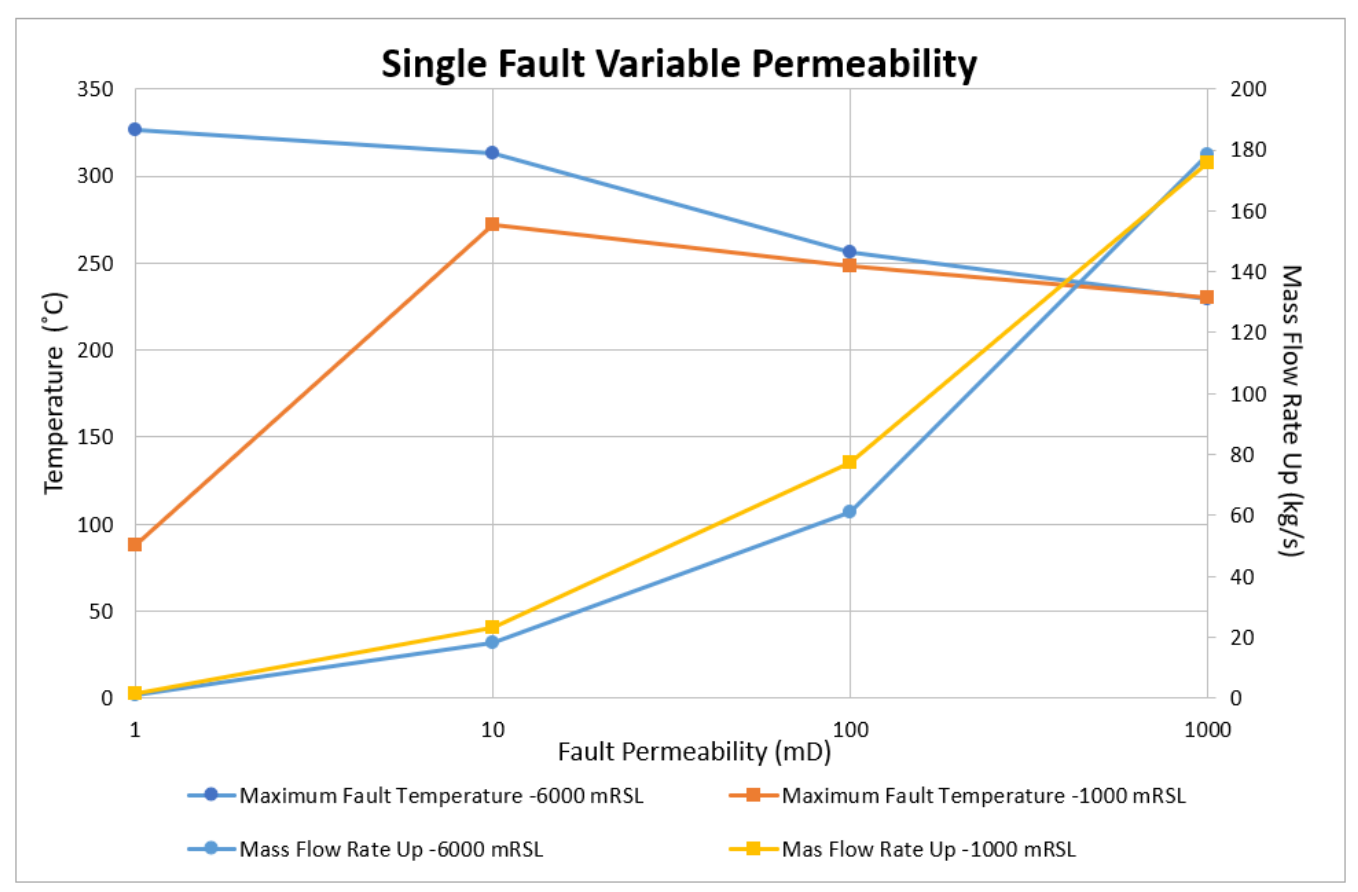

Figure 31: Single fault simulation varying permeabilities. Temperature and mass flow values are graphed as permeability increases logarithmically by a factor of 10 .

An increase in fault permeability results in with $1 \mathrm{mD}$ fault the difference between -6000 and $-1000 \mathrm{mRSL}$ is the greatest, this divergence decreases as permeability increases. The fluid is compressed liquid single phase so the liquid temperature and enthalpy are directly correlated as seen in Figure 32. 


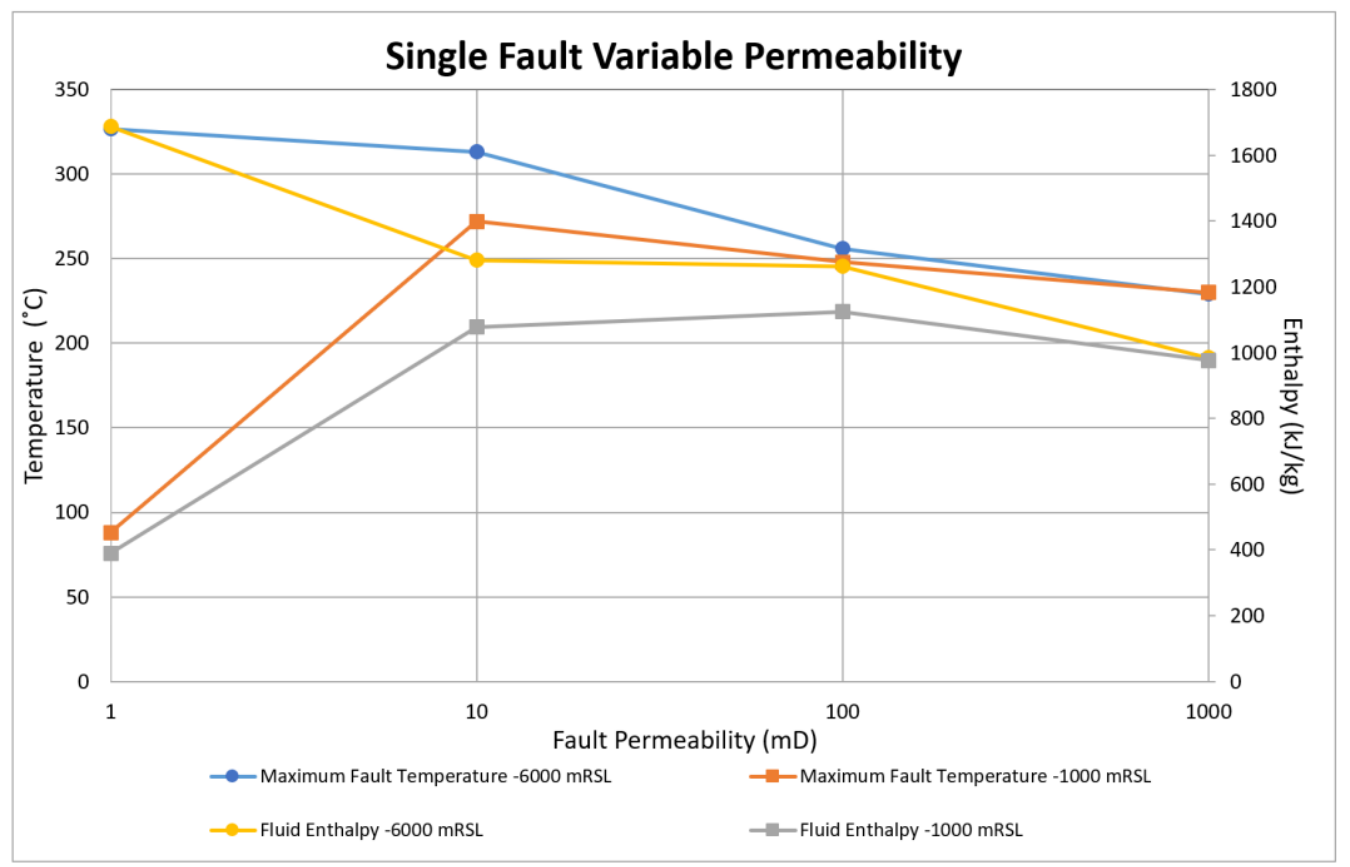

Figure 32: Single fault varying the permeability showing the relationship between the fault temperature and the up flowing fluid enthalpy.

As discussed previously the energy flow up in the fault is predominantly from the convection of the fluid, the conduction across the fault is negligible in comparison to the energy flow (as long as the fault is permeable enough to allow fluid convection). Therefore, the relationship between the mass flow and energy flow rates are directly correlated as seen in Figure 33.

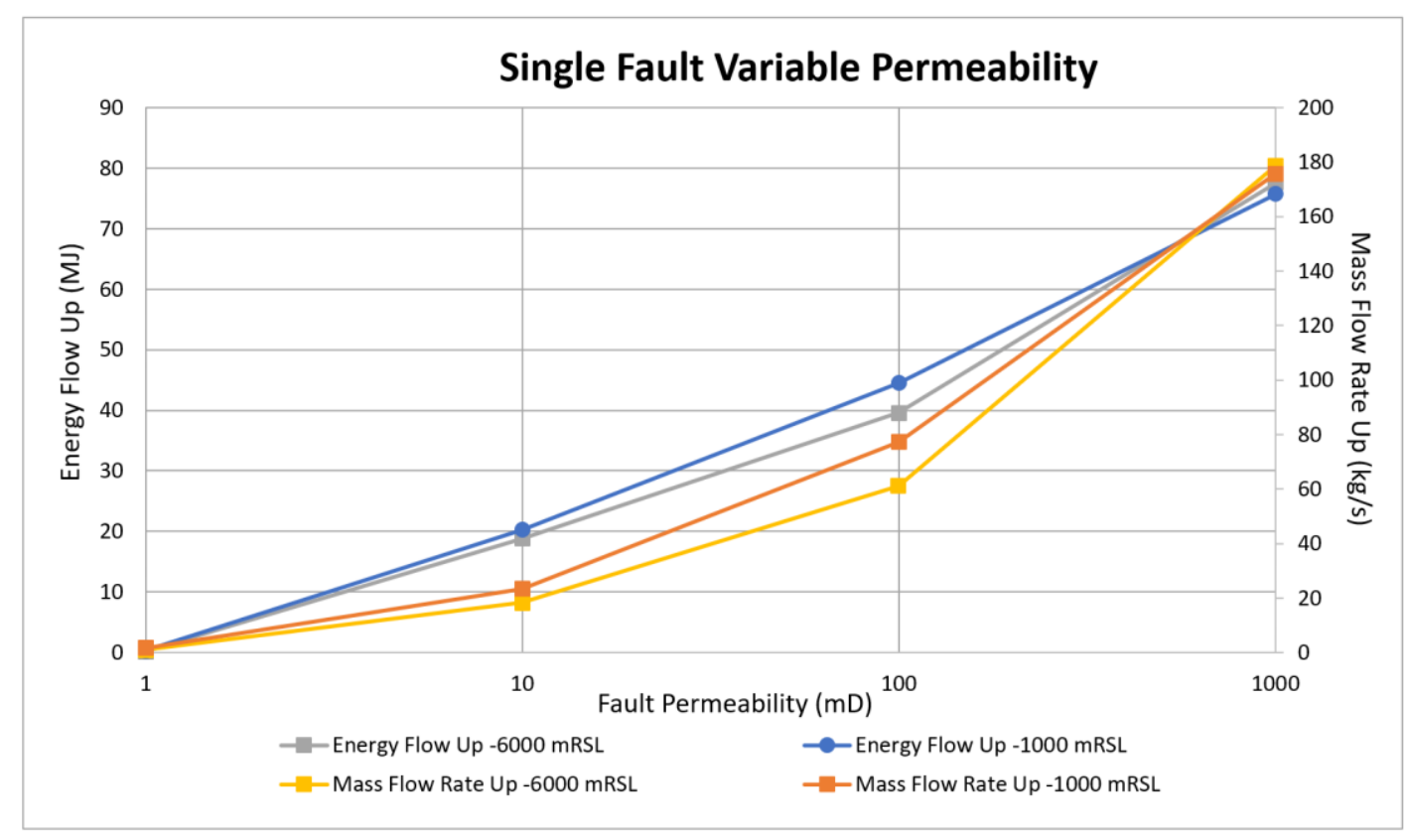

Figure 33: Single fault varying the permeability showing the relationship between the energy flow up and the mass flow up. 
Given the base case $10 \mathrm{mD}$ fault varying the vertical permeability results in a similar relationship. The highest temperature out of all the sensitivity models resulted from the $1: 10 \mathrm{mD} \mathrm{k} / \mathrm{k}_{\mathrm{h}}$, fault at $353{ }^{\circ} \mathrm{C}$ at $6000 \mathrm{mRSL}$ the higher $\mathrm{k}_{\mathrm{v}} / \mathrm{k}_{\mathrm{h}}$ ratio decreases the temperature and increase the mass flow. At $-1000 \mathrm{mRSL}$ the same relationship exists above $1 \mathrm{mD}$. Figure 34 shows the relationships described.

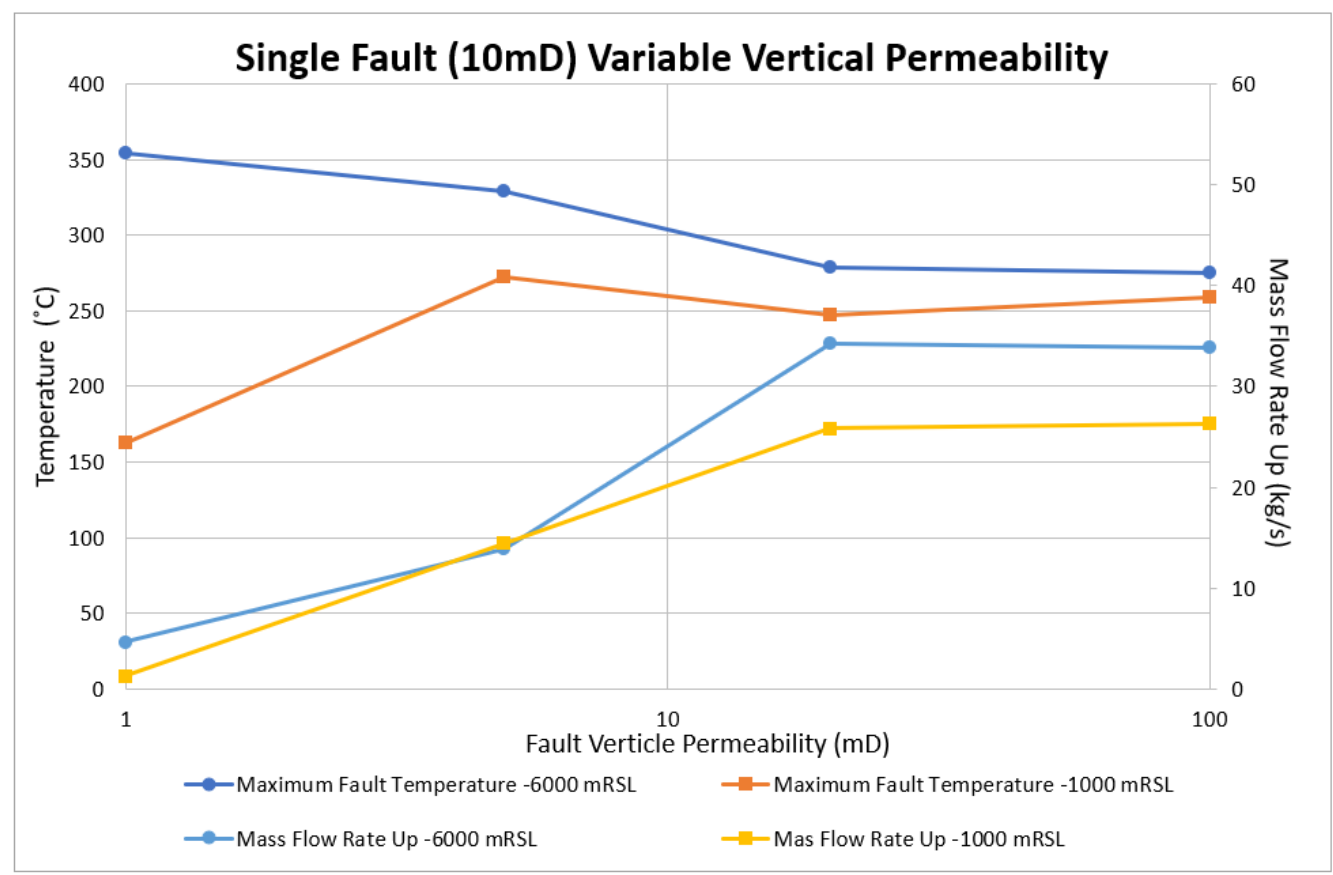

Figure 34: Single fault simulation $(10 \mathrm{mD} x$ and $y)$ varying the faults vertical permeabilities. Temperature and mass flow values are graphed as permeability increases logarithmically by a factor of 10 .

The $\mathrm{k}_{\mathrm{v}} / \mathrm{k}_{\mathrm{h}}$ permeability for a higher permeable fault of $100 \mathrm{mD}$ has a lower temperatures and higher flow rates as expected from the previous two scenarios. Vertical permeability seems to be the predominate factor controlling convection temperature at depth as an increased vertical permeability decrease the temperature at $-6000 \mathrm{~m}$. The shallower zone needs more convection to allow convection farther up. mass flow increase with increase permeability. With a $10 \mathrm{mD}$ kh the mass flow plateaus at $200 \mathrm{mD}$ while in the $100 \mathrm{mD}$ kh fault the mass flow significantly for the $-6000 \mathrm{mRSL}$ from $200 \mathrm{mD}$ to $1000 \mathrm{mD}$ as shown in Figure 35. 


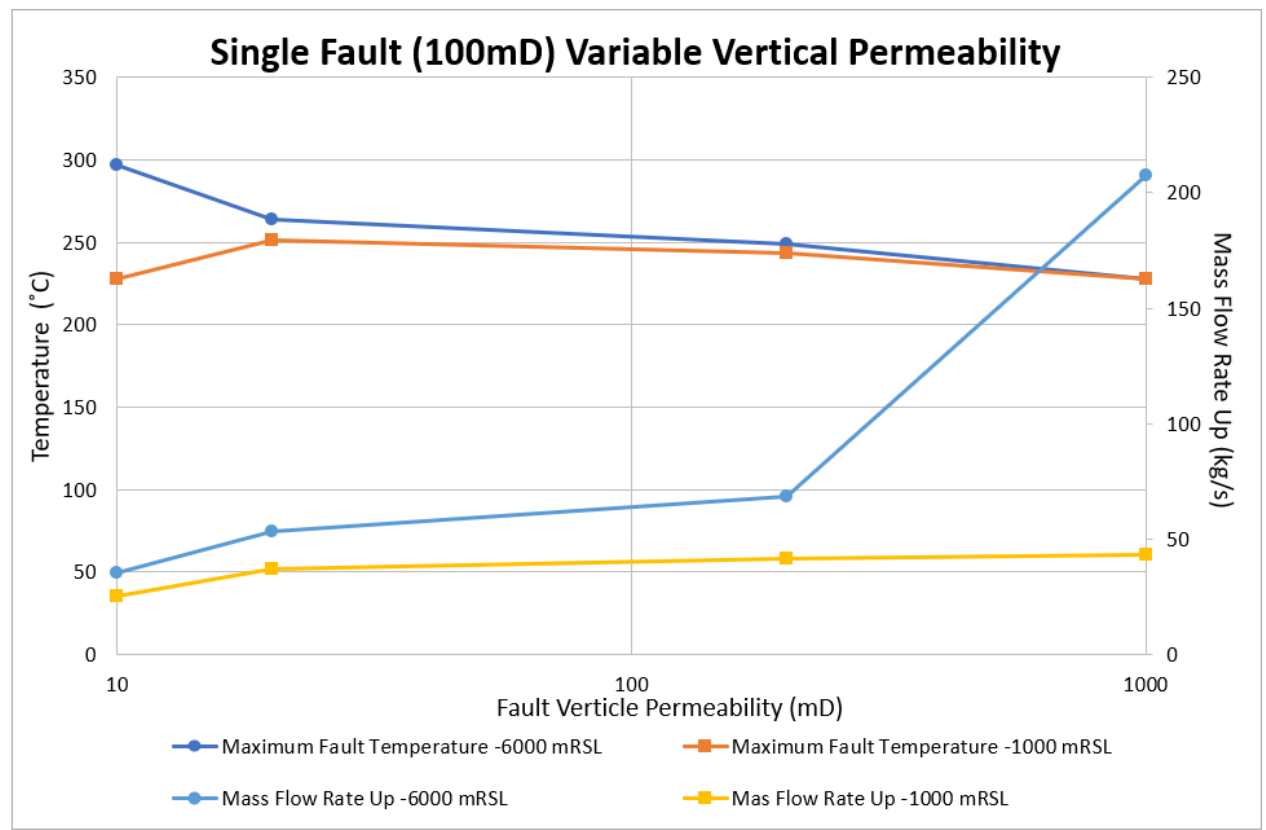

Figure 35: Single fault simulation (100 $\mathrm{mD} x$ and $y$ ) varying the faults vertical permeabilities. Temperature and mass flow values are graphed as permeability increases logarithmically by a factor of 10 .

An increased fault area has a proportional increase in mass flow. For both -1000 and $-6000 \mathrm{~m}$. the increase is greater in the deeper zone. The larger fault rate also slightly decreases the convection temperature. Figure 36 shows the relationship between temperature and flow rate with increasing the simulated fault area for both layers the mass flow increase is greater at the deeper $-6000 \mathrm{~m}$ elevation than the shallower $-1000 \mathrm{~m}$. There is a positive liner relationship to increasing the fault area and the upflow rate. However, there is a decrease in fluid temperature at both layers as the area fault are increase of $\sim 25^{\circ} \mathrm{C}$, and $20^{\circ} \mathrm{C}$ the deep and shallow layer respectively. 


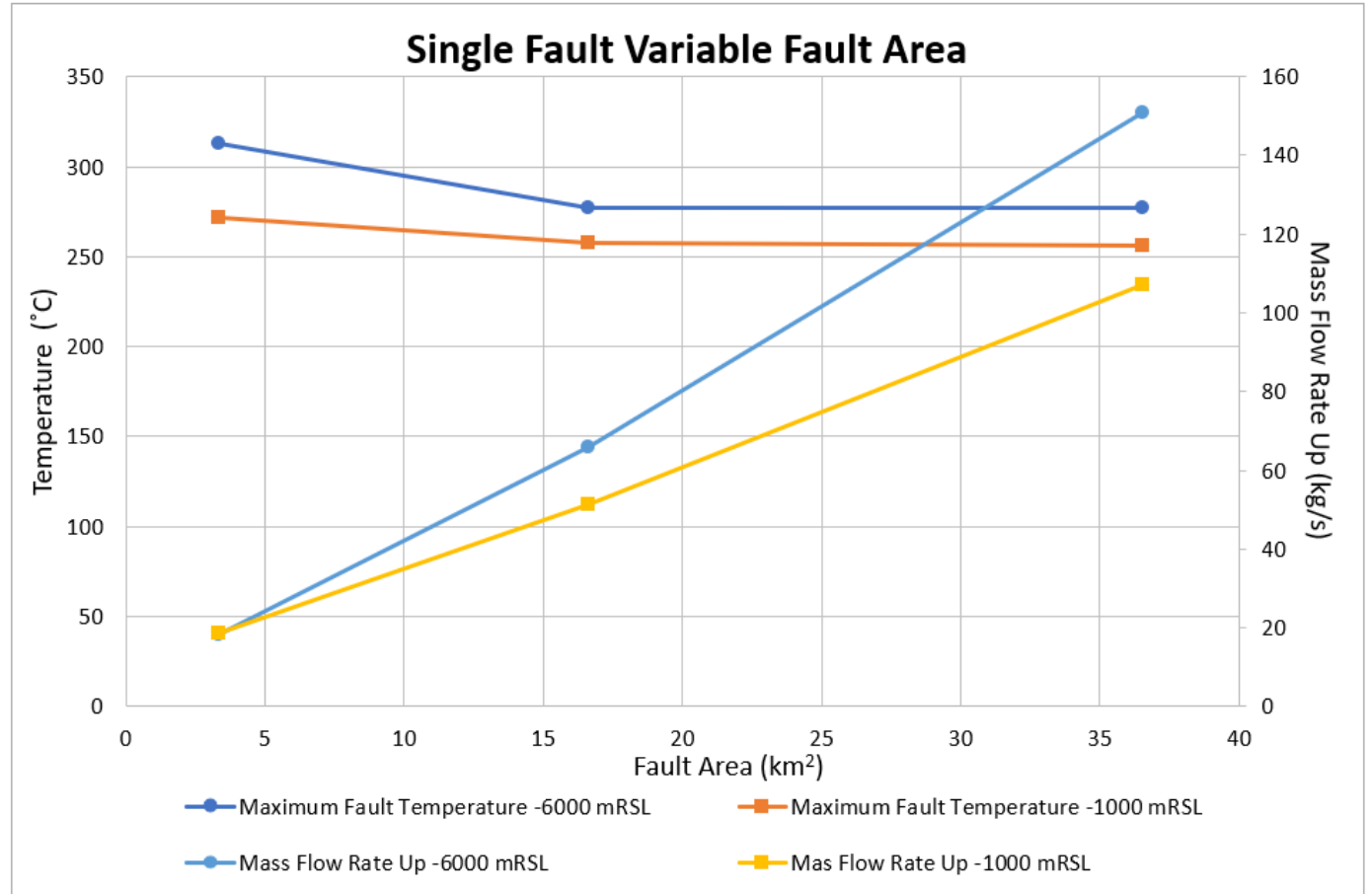

Figure 36: Single fault simulation (100 mD $x$ and $y$ ) varying the faults vertical permeabilities. Temperature and mass flow values are graphed as permeability increases logarithmically by a factor of 10.

Increased fault length proportionally increases the mass flow. The temperature changes are greater at $1000 \mathrm{mRSL}$ then $-6000 \mathrm{mRSL}$. Figure 37 shows the relationship described. It looks as though increasing the fault length beyond $\sim 13 \mathrm{~km}$ for the deeper zone may reduce the convection flow rate as the length to height ration of the convection cell increases. 


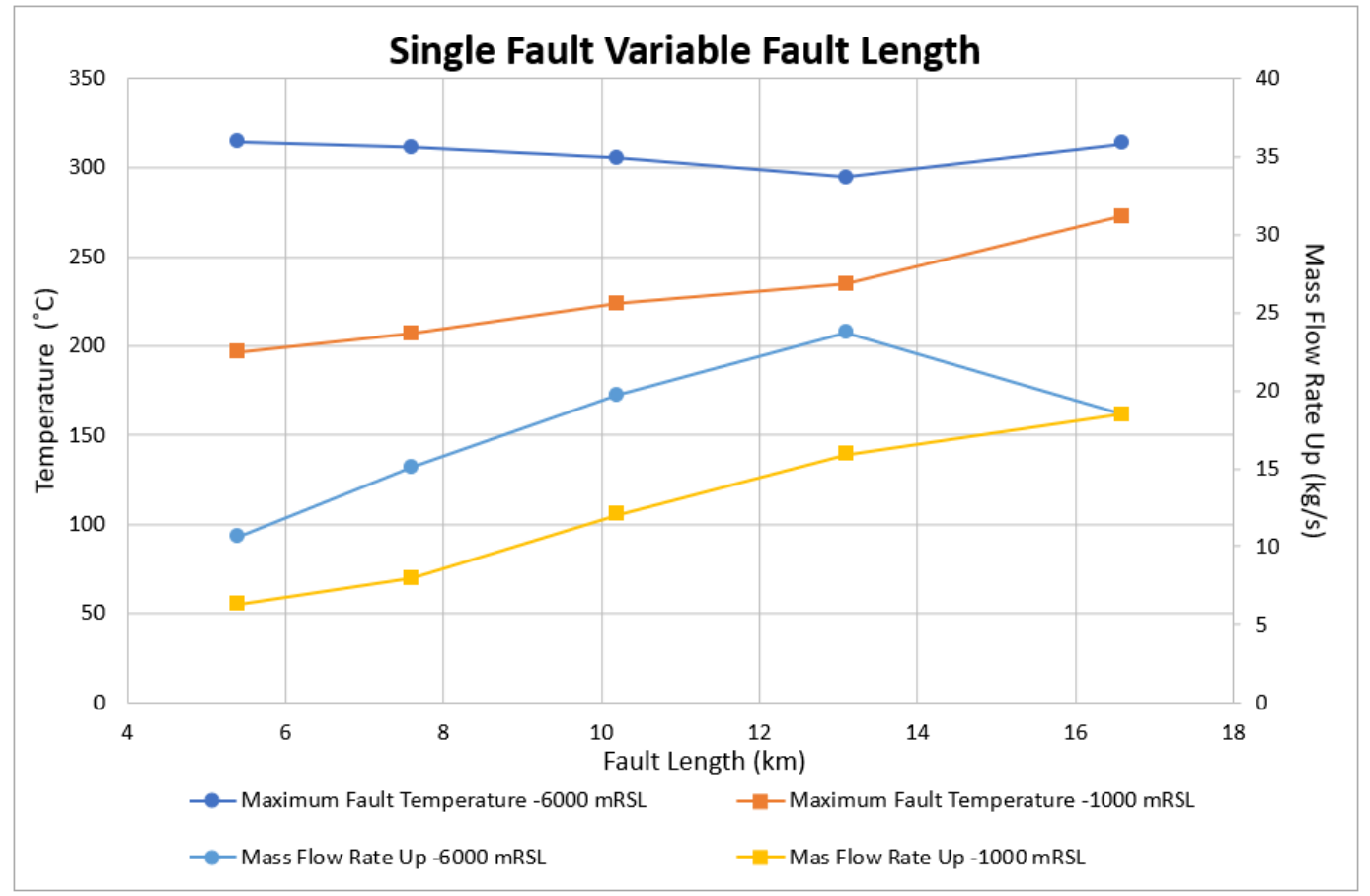

Figure 37:Fault temperature and mass flow rate with simulated fault lengths.

Hot plate depth was only evaluated on the shallower zone on $-1000 \mathrm{~m}$ and $-3000 \mathrm{~m}$ layers. Predictably in both scenarios decreasing the hot plate depth increases the fault temperature but decreased the mass upflow rate. The deeper zone has a lager decrease in mass flow rate as the hot depth is reduced this may again be a result of the ratio of length to height of the convection cell decreasing. While the temperature increases proportionally between $-1000 \mathrm{mRSL}$ and $-3000 \mathrm{mRSL}$ as the hot plate depth decreases. 


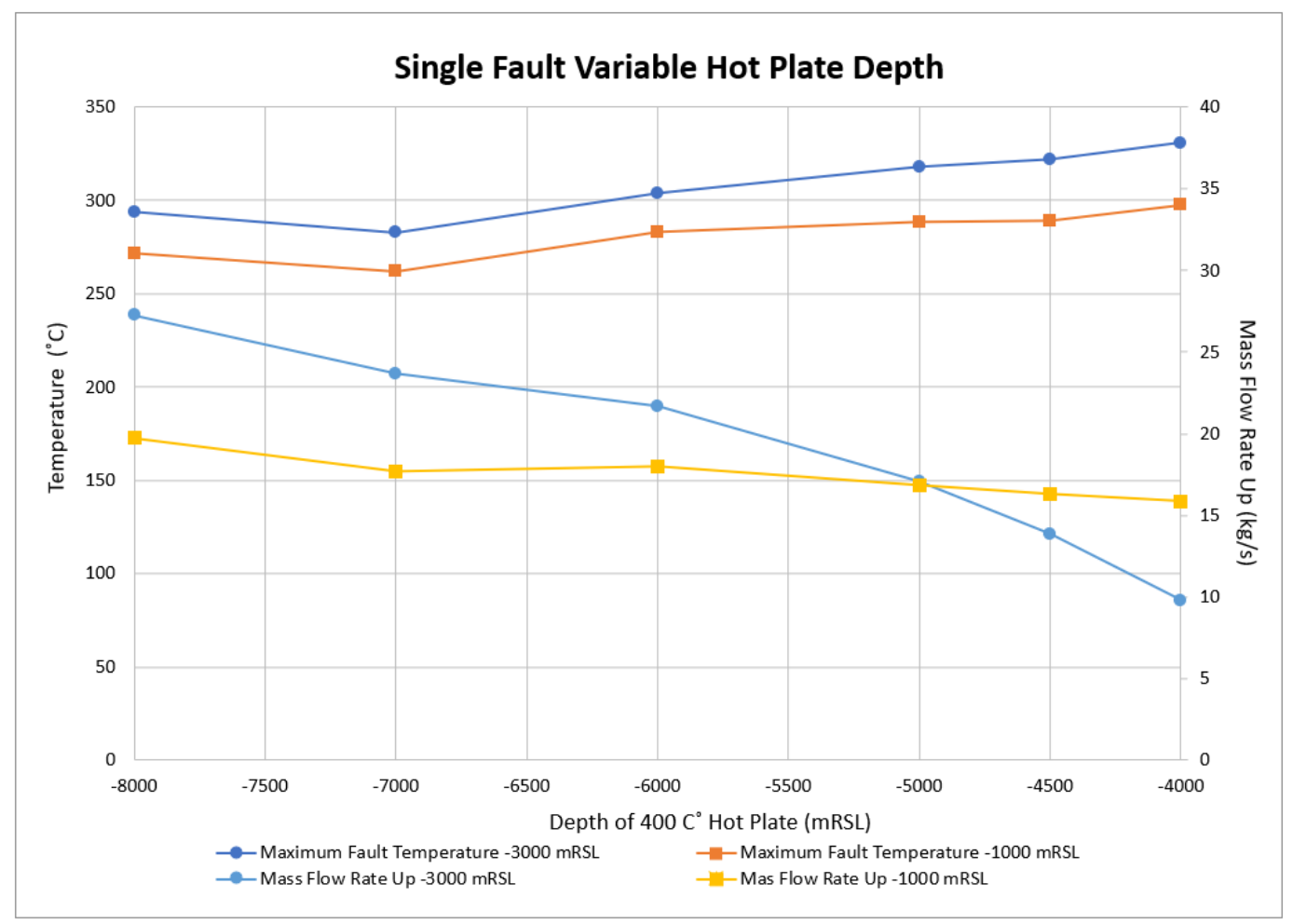

Figure 38: Fault temperature and mass flow rate as the hot plate depth is varied.

Appendix B.2.4 - B.2.6 shows the relationship with fault porosity, specific heat, density and conduction. Varying all of these parameters does not have create a significant change the fault temperature and mass flow rate. Fault conductivity can affect the fault conduction and mass flow significant when the value is less than $1 \mathrm{~W} / \mathrm{m}^{\circ} \mathrm{C}$ or greater than $5 \mathrm{~W} / \mathrm{m}^{\circ} \mathrm{C}$ but within realistic geologic values simulated the changes to were less than $7 \%$ of the base case.

In most scenarios an increased mass flow rate is inversely related to the convection temperature of the fault will occur at a point in which. Aspects of the fault block model that will be taken into the Rotokawa geothermal model are. Low vehicle permeability allows from high convection temperatures. Increase area and decreasing the vertical permeability should allow for a larger upward mass flow rate at higher temperature.

\section{Rotokawa Geothermal System Model}

A total of 41 Rotokawa models were created with the grid and rock types described in the prior methodology section. Dozens of more models were required for refinement of the final gridding and rock properties. The resulting model RK38 closely matched the natural state temperatures in each area of the reservoir described in Hernandez et al. 2015 (Figure 21). The natural state temperature and pressure match can be seen in Figure 39. RK14, RK17, RK24, RK19 and RK21 were selected to represent the temperature profiles in the Central, West, South-East, North and South-West areas of the field respectively. The natural state pressure from the RK38 model is also shown compared to natural state pressure gradients in Davidson et al. 2012. The transition from the intermediate pressure gradient to the deeper pressure gradient occurs at the clay cap above the reservoir and is a result of different temperatures (fluid density) in the intermediate aquifer and reservoir. The reservoir pressure is a little 
over 10 bar over pressure at the reservoir cap (-750 mRSL, of model RK38 pressure, Figure 39). A similar observation was seem is also seen in Hernadez et. al, 2015) The natural state pressure was defined by a few initial wells but there seems to be around 10 bar over pressure at $-750 \mathrm{mRSL}$ associated with the cap of the deep reservoir at the clay cap as a result upward buoyancy of the up flow. 

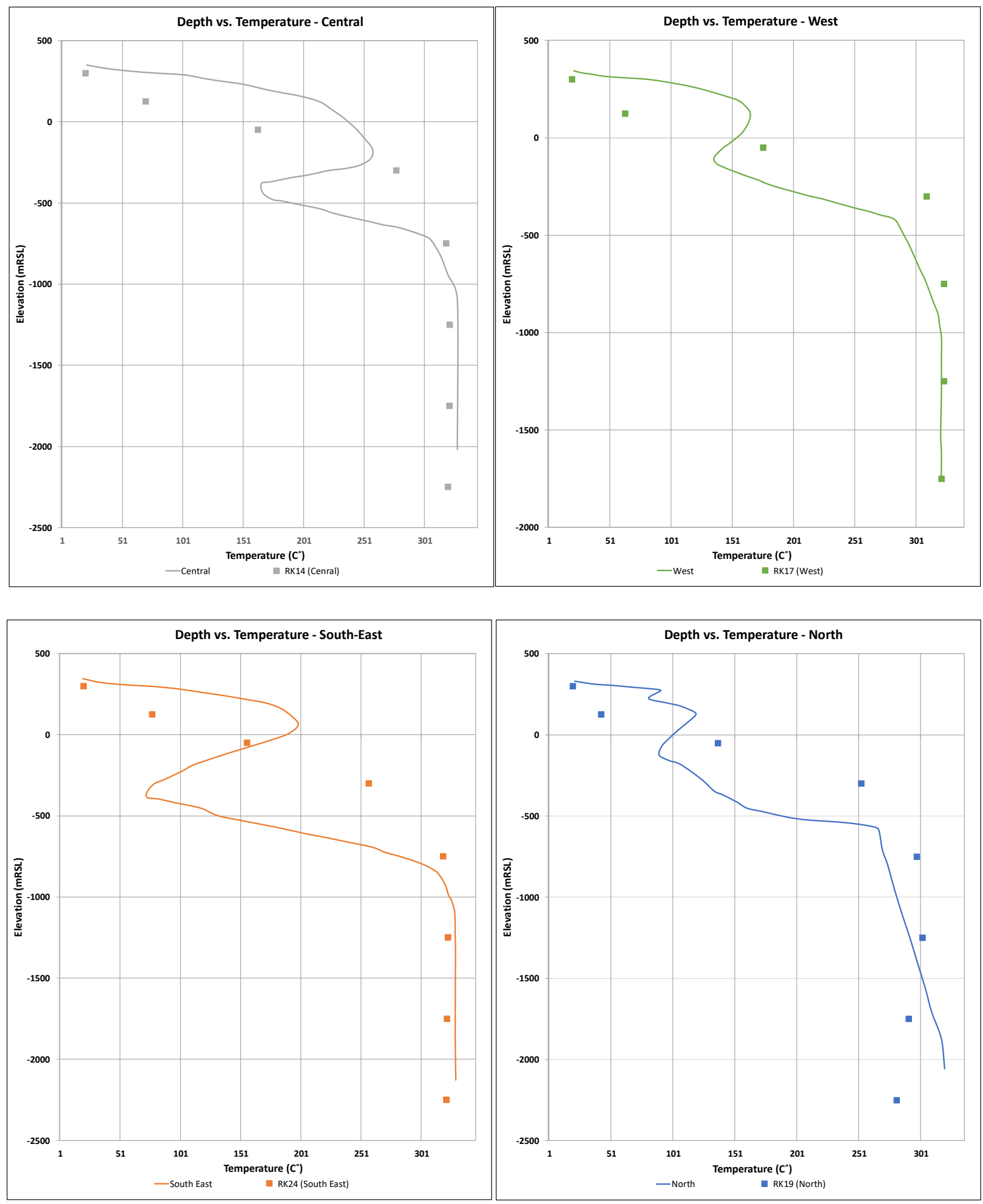


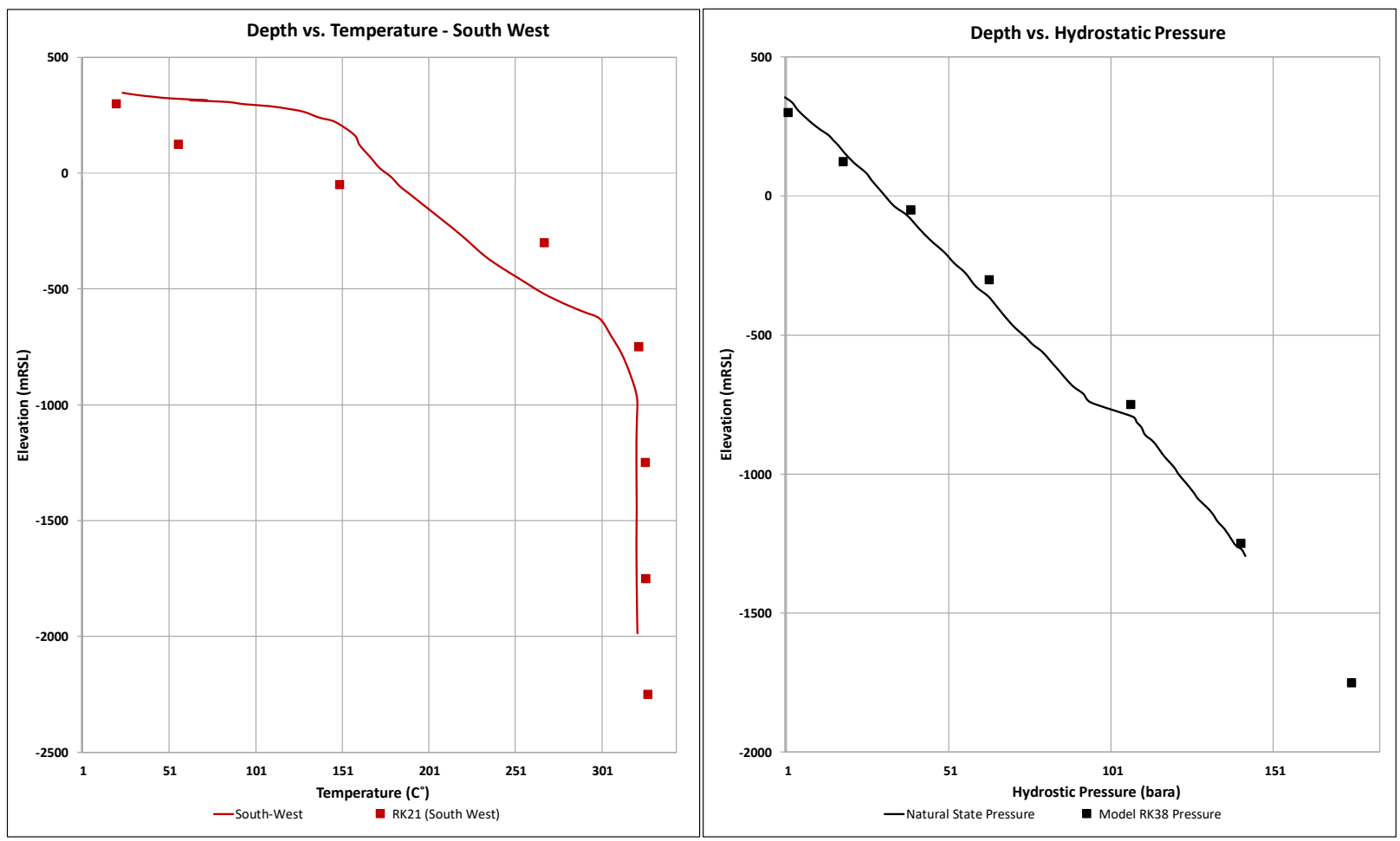

Figure 39: Model RK38 natural state temperature and pressure match for the simulated temperatures are shown (points) shown alongside the published natural states temperatures for each region of the reservoir. Natural state temperatures are from Hernandez et.al 2015 and natural state pressures are from Davidson et.al 2012.

The large grid block and layer sizes limit the resolution of the model. The intermediate aquifer (seen by the temperature reversal ranging $0 \mathrm{mRSL}$ to $-500 \mathrm{mRSL}$ could not properly modeled in the natural state conditions as a result. From 0 to $-500 \mathrm{mRSL}$ both the shallow and deep clay cap are combined into one zone with the 0 to -100 mRSL to represent the Hukka Falls formation. However, the objective was to understand the deep convection so modeling above the reservoir was not the primary objective. The top of reservoir was given a higher vertical and horizontal permeabilities to represent the unconsolidated volcanic infill and shallow soil and above the clay cap

Model RK38 had a natural state temperature match for each zone of the reservoir as seen in Figure 39. RK38 rock properties are shown in appendix B.1.2. Each layer can also be seen in appendix B.1.3. that shows the rock type denotations within the reservoir model for each layer.

Without a greater vertical resolution, the intermediate aquifer could not be modeled so the temperature inverses from 0 to $-750 \mathrm{mRSL}$ in the south-east, north, central and western areas of the field could not be matched.

The main reservoir is from -750 to $-3000 \mathrm{mRSL}$ and can be seen in the temperature plot by the isothermal temperature vs. depth profile. The highest simulated temperature was located west of RK21 and south of RK29 both of these upflow zones can clearly be seen in appendix B.1.5. the temperature contour of $310^{\circ} \mathrm{C}$ as well as the temperature contour plots in Figure 41.

Simulating convection cells proved to be very difficult as convection cells can be more unpredictable given the simple rock types and large grid block used in this model. It would have been much simpler to 
choose a location to inject as is done in a geothermal reservoir model. the best match was given with the but the second up flow zone gave a much better temperature match that forcing a single upflow to the south under the current. The secondary upflow zone is likely a result of a simplistic reservoir permeabilities with large cell sizes and the CFF terminating into the Rotokawa Andesite and Greywacke as this was the primary upflow feature. The highest permeability zones are not correlated with the highest temperatures so placement of hot up flows is difficult as a result.

Below the reservoir from $-3000 \mathrm{~m}$ to $-3500 \mathrm{mRSL}$ is the transition from higher reservoir permeabilities to a lower that still has some vertical permeabilities in the faults to allow upflow into the field. This is the zone where the reservoir intercepts the high temperature convection zone. The 3 and $5 \Omega \mathrm{m}$ contours are present and intercepted by the CFF, IFF and PFF fault allowing upflow.

The high temperature convection zone is at the depth -3500mRSL to $-5950 \mathrm{mRSL}$ the permeabilities are much lower That threshold is $10^{-15} \mathrm{~m}^{2}$ for a temperature of $200-250^{\circ} \mathrm{C}$ (Hanano, 2004). The high temperature convection zone was found to convect at high temperature ( $>340 \mathrm{C}$ ) in areas with a low vertical permeability. Below the reservoir vertical permeability will be assigned from the MT resistivity contours.

Finally, the bottom 50m of the model represents the brittle ductile transition and was given a fixed temperature and a very low permeability that will allow no convection. It is assumed the entire area under the grid is given the same heat flow with the same reservoir while Ratouis and Zarrouk 2016, and Wallis et al. 2017 postulate a thermal anomaly below the field. This thermal anomaly may not be located directly below the field as the MT resistivity from Bertrand et al. 2015 suggests offset upflows in some of the TVZ fields such as Ohaaki.

A summary of the reservoir zones as described can be seen in Table 5 below.

\begin{tabular}{|c|c|c|c|}
\hline \multicolumn{4}{|c|}{ Model Permeability Zones } \\
\hline Depth (mRSL) & Permeability & Structure/Geology & Comments \\
\hline 350 to 0 & $\begin{array}{l}\text { High Permeable }(100- \\
500 \mathrm{mD})\end{array}$ & $\begin{array}{l}\text { Rainfall infiltration, high permeability with } \\
\text { no fault influences. }\end{array}$ & $\begin{array}{c}\text { Shallow unconsolidated volcanic infill highly } \\
\text { permeable and shallow aquifer. }\end{array}$ \\
\hline 0 to -500 & Low Permeability ( $<1 \mathrm{mD})$ & $\begin{array}{c}\text { Altered smectite clay cap above reservoir } \\
\text { with decrease perm outside of the } \\
\text { reservoir }\end{array}$ & $\begin{array}{l}\text { Altered formation Clay cap (top of the } \\
\text { reservoir). Conduction temperature gradient } \\
\text { in this zone. }\end{array}$ \\
\hline-500 to -3000 & $\begin{array}{l}\text { High permeable }(10 \mathrm{mD} \text { to } \\
500 \mathrm{mD})\end{array}$ & $\begin{array}{l}\text { High permeabilities with field faults } \\
\text { creating conduits for high upflow rates. }\end{array}$ & $\begin{array}{l}\text { Convection temperature gradient inside with } \\
\text { high vertical permeability concentrated the } \\
\text { IFF, PFF and CFF. }\end{array}$ \\
\hline-3000 to -3500 & $\begin{array}{l}\text { Low perm, higher fault } \\
\text { perm }(5 \mathrm{mD} \text { to } 50 \mathrm{mD})\end{array}$ & $\begin{array}{l}\text { Low permeabilities with higher vertical } \\
\text { permeability in faults, that allow upflow } \\
\text { from supercritical convection cell. }\end{array}$ & $\begin{array}{l}\text { Transition from high temperature convection } \\
\text { below the field and reservoir. }\end{array}$ \\
\hline-3500 to -5950 & $\begin{array}{l}\text { Very low permeability } \\
\left(5 \mathrm{mD} k_{h},<2 \mathrm{mD} \mathrm{k}_{\mathrm{v}}\right)\end{array}$ & $\begin{array}{c}\text { Very low vertical permeability slightly } \\
\text { higher horizontal permeability to allow for } \\
\text { sufficient flow from downflow into } \\
\text { convection cell. }\end{array}$ & $\begin{array}{l}\text { High temperature convection system below } \\
\text { the reservoir. }\end{array}$ \\
\hline-5950 to -6000 & No permeability $(<1 \mathrm{nD})$ & Brittle Ductile Transition & $\begin{array}{c}\text { Ductile, impermeable rock with a fixed } \\
\text { temperature. }\end{array}$ \\
\hline
\end{tabular}


A temperature contour of Model RK38 can be seen in Figure 40 below at $-2000 \mathrm{mRSL}$. Vertical temperature contours for $-1500 \mathrm{~m},-2000,-2500 \mathrm{~m}$ and $-3000 \mathrm{~m}$ are shown in Figure 41 . The temperature contours are comparable to the temperature contour from Boyer and Holt 2010 (Figure 19). The conceptual model from Hernandez et. al 2015 only has a single upflow source in the south-eastern part of the field. It can be seen in the RK38 Model there are two upflow zones. The convection cells proved to be difficult to model and the highest temperatures are not located in the high vertical preamble faulted zones, as mass flow and fluid enthalpy can be negatively correlated in natural state convection. The simplicity and symmetry of the permeability structure below the field lead to two upflows both located along the CFF as seen in Figure 40.

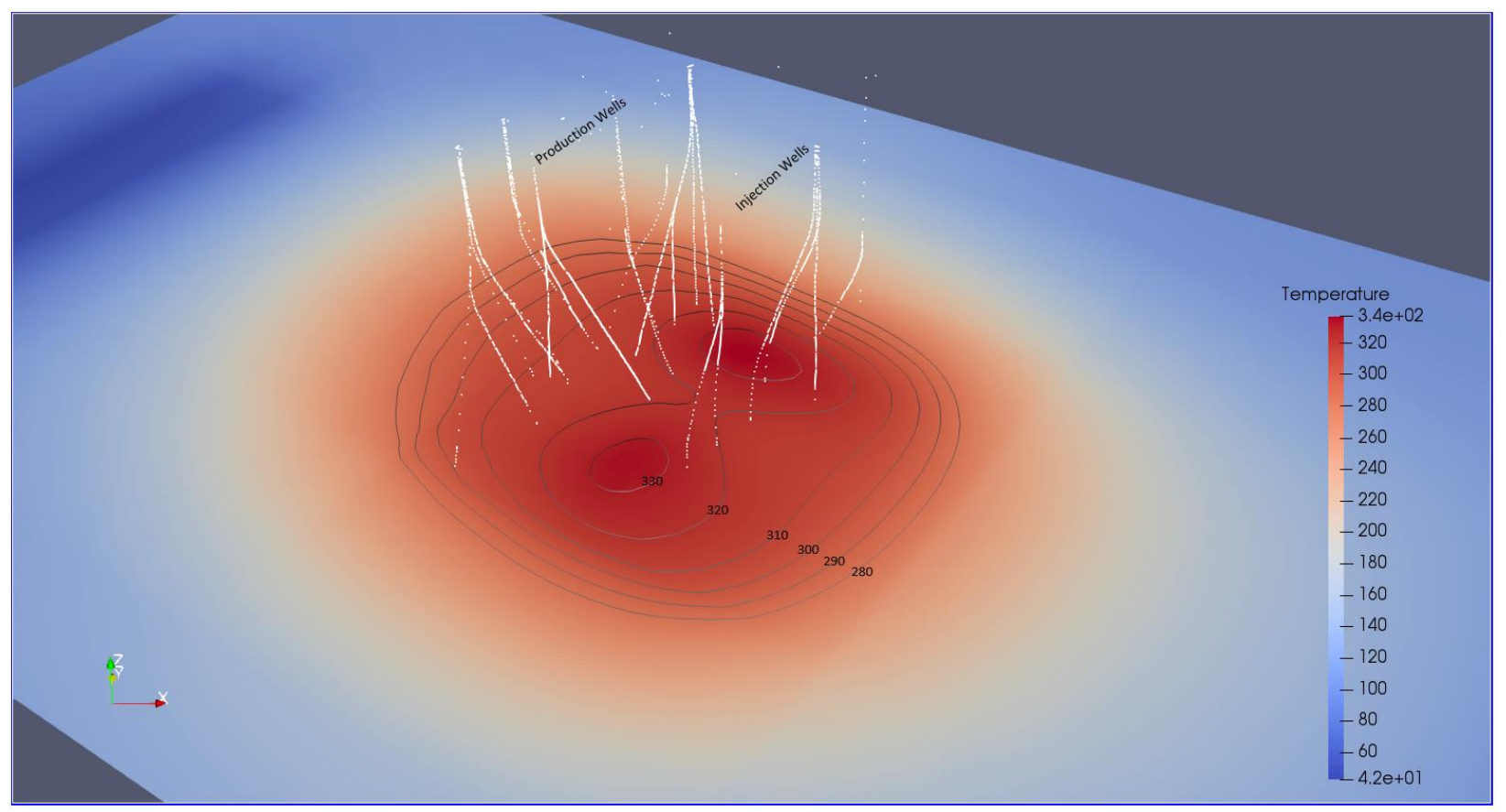

Figure 40:Model RK38 Temperature contour at-2000mRSL. Production and injection well tracks are also shown. 


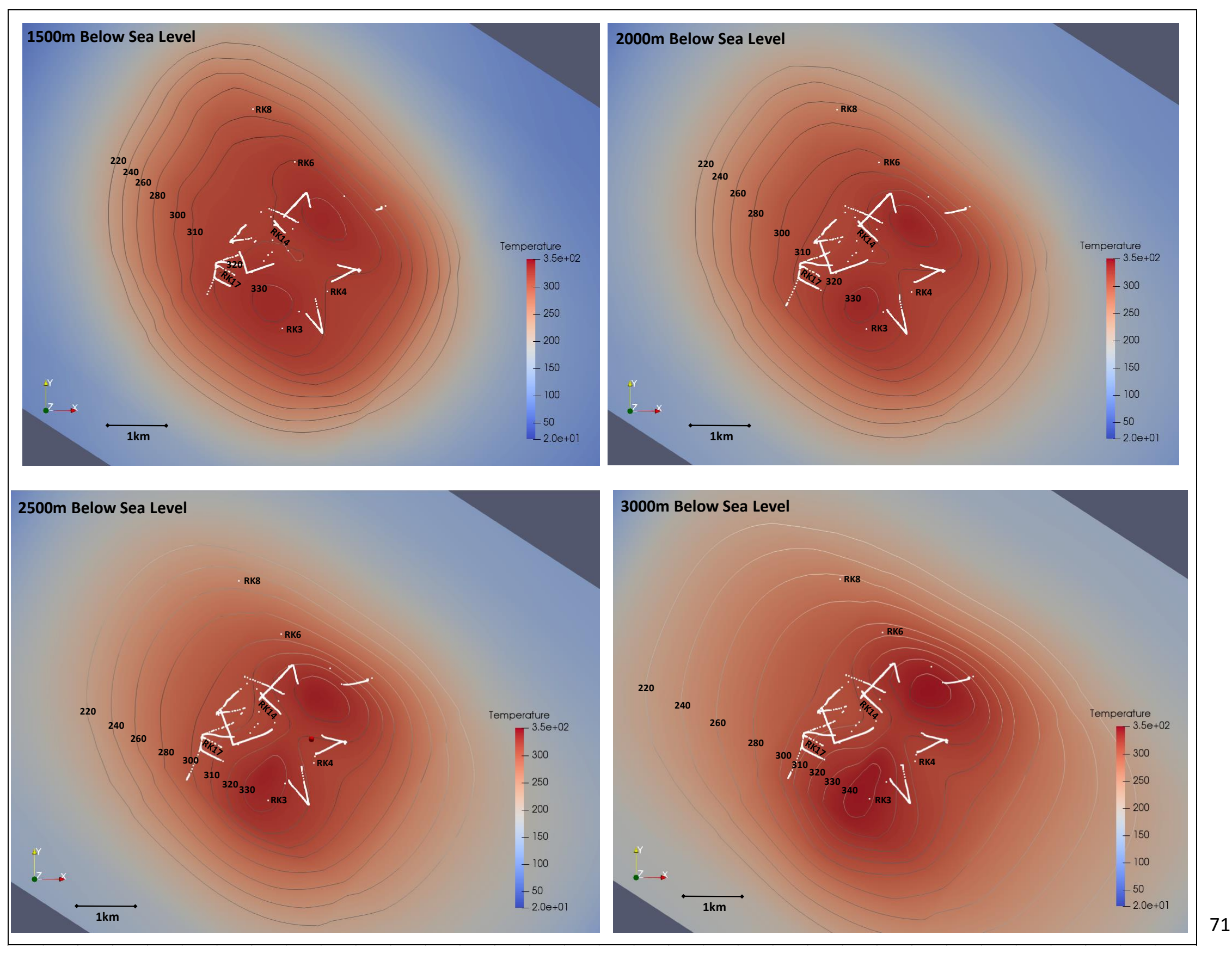




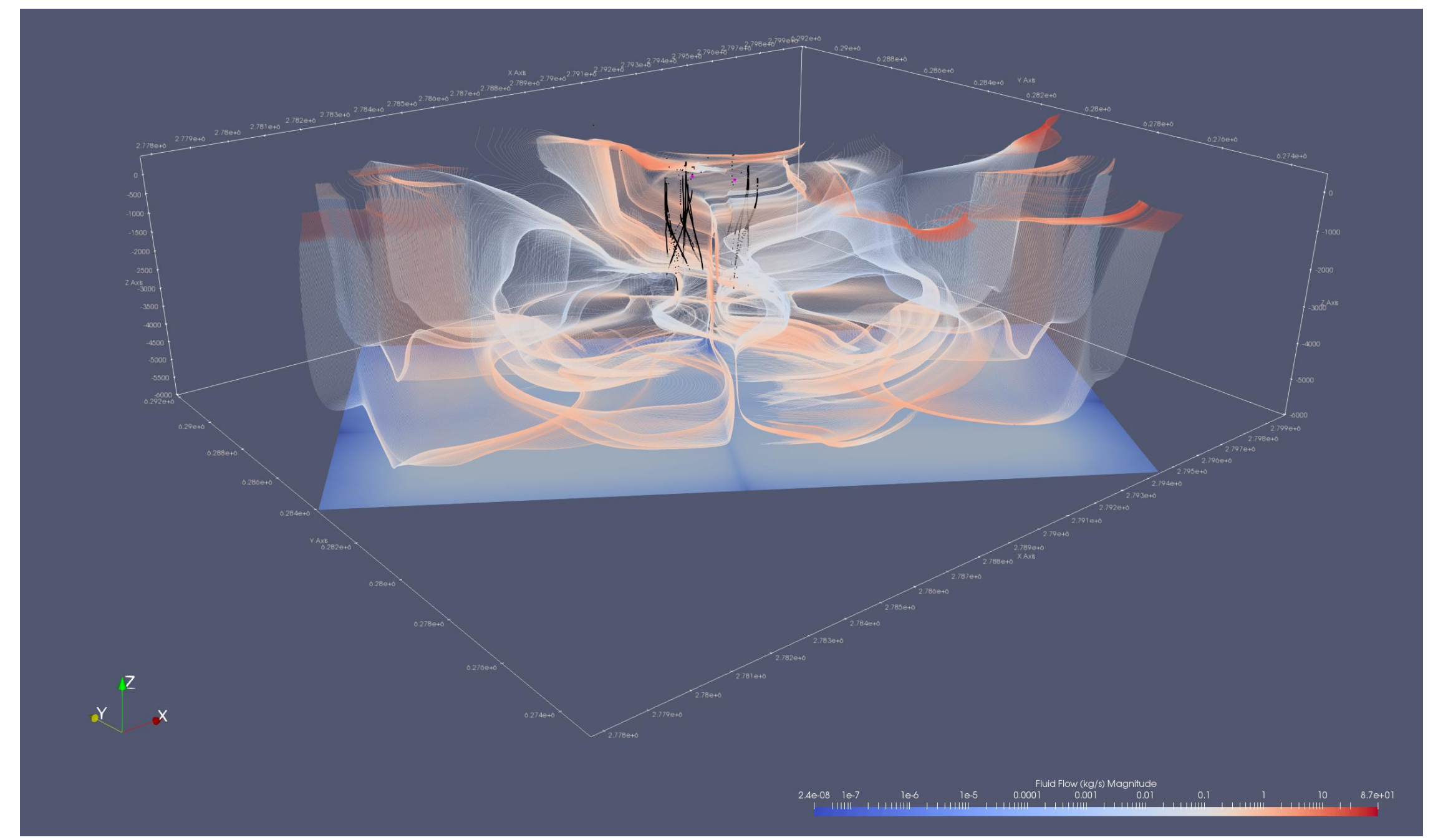

Figure 42:Model RK38 streamlines show direction of convection and are colored to show magnitude of the mass flow $(\mathrm{kg} / \mathrm{s})$. The warm colors represent higher rates of mass flow showing the natural state convection cells. Cool colors represent low rates of mass flow. An annotated image is shown below. 


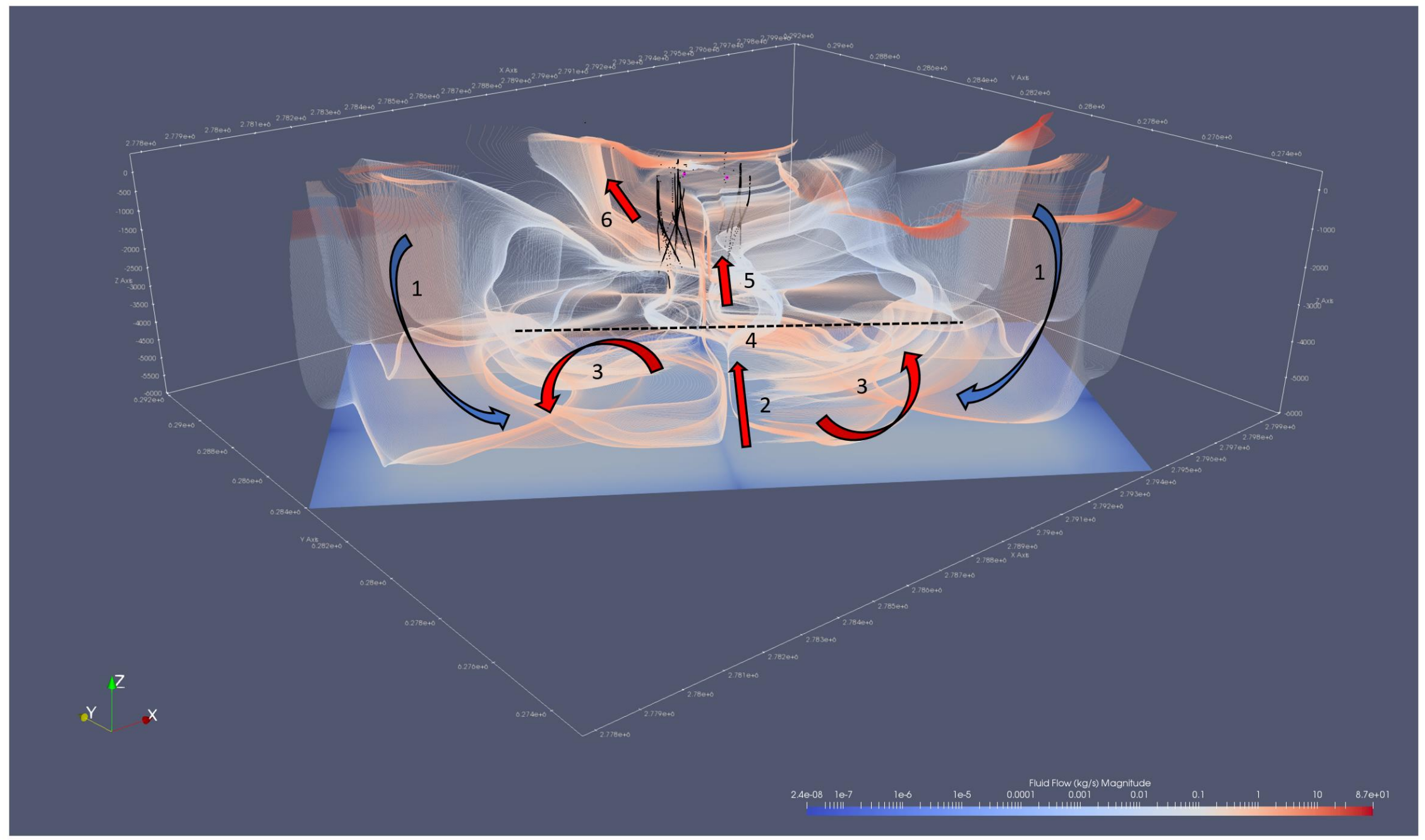

Figure 43:Model RK38 streamlines mass flow labeled to show convection processes. 1) Downflow in the NW and SE faulted sections outside the reservoir 2) High temperature upflow within the $3 \Omega \mathrm{m}$ contour below the reservoir. 3) High temperature convection in the lower permeability deep fractured zone. 4) Transition from deep low permeability convection to reservoir permeability and high fault permeabilities 5) Upflow into the field through CFF fault 6) Outflow of the reservoir to the north with low permeable clay cap preventing downflow into the system. 


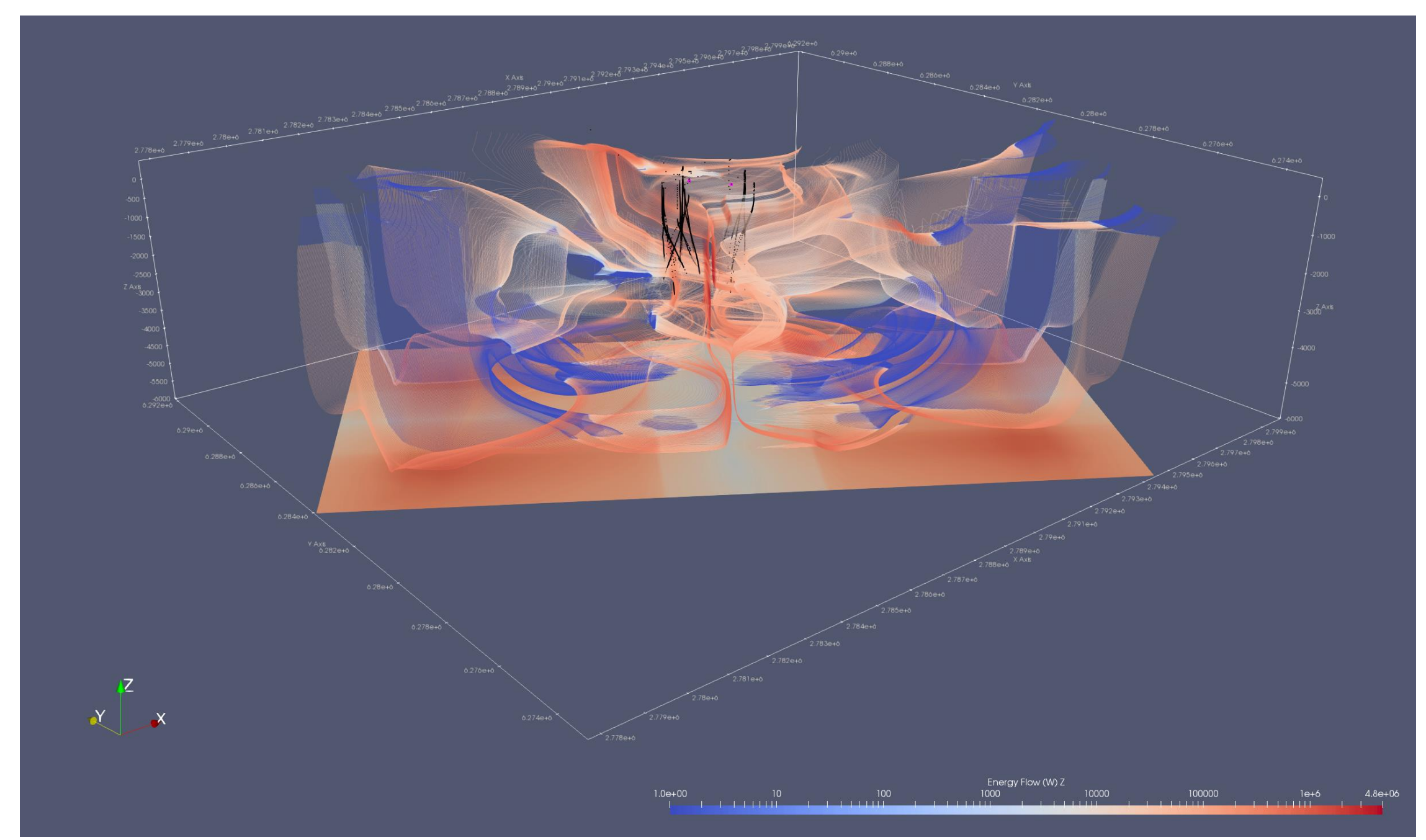

Figure 44: Model RK38 vertical Energy flow. Streamlines so direction of fluid convection and are colored to on the energy flow magnitude in the vertical direction. Cooler colors compared to the figure above can now show down flow (1) and predominantly lateral convection into the higher vertical perm $3 \Omega m$ contour (3). The warm colors show the upflow within the $3 \Omega m$ contour (2), the upflow in the CFF and IFF (5) and the outflow of the field to the north (6). 
To match previous reservoir modeling the convection within the geothermal system needs to provide $\sim 150 \mathrm{~kg} / \mathrm{s}$ of up flow at $\sim 1500 \mathrm{~kJ} / \mathrm{kg}$. In steady state the up flow and downflow matches across the entire model layer but downflow is concentrated in external faults while up flow is concentrated in the highest vertical permeable path ways upward.

Without the refined gridding at in the top of the reservoir there is not the shallow aquifer to cap the shallow temperatures resulting in much higher temperatures in This is especially prominent in the south east and the north as seen in the large temperature reversals in Figure 39.

Table 6 below shows vertical mass flows into the base of the reservoir (-3000mRSL). This table shows the vertical mass flows across this layer for each rock type in the reservoir model at this layer. Almost all the of the reservoir downflow (99.5\%) is outside of the field in the fault zones outside the reservoir. Likewise, almost all of the upward convection occurs within the reservoir and boundary (98.6\%). The majority of the upflow within the reservoir is primarily in the fractured reservoir and CFF. The average fluid enthalpy of the upflow fluid is was $1485 \mathrm{~kJ} / \mathrm{kg}$.

The highest enthalpy upflow was in the Basement greywacke with a vertical permeability of $1 \mathrm{mD}$. The greywacke is over the southern upflow resulting in the higher enthalpy. The CFF is the largest flow per area at $165.5 \mathrm{~kg} / \mathrm{s} / \mathrm{km}^{2}$ with $33.1 \%$ of the upflow into the field though the CFF.

All of the layer elevation and thickness can be seen in Model RK38 can be seen in appendix B.1.2.

\begin{tabular}{|c|c|c|c|c|c|c|}
\hline \multicolumn{7}{|c|}{ Model Vertical Mass Flow Rates at -3000mRSL } \\
\hline Rock Type & $\begin{array}{l}\text { Downflow } \\
\text { rate }(\mathrm{kg} / \mathrm{s})\end{array}$ & $\begin{array}{c}\text { Upflow Rate } \\
(\mathrm{kg} / \mathrm{s})\end{array}$ & \% Downflow & \% Upflow & $\begin{array}{l}\text { Upflow } \\
\text { Enthalpy } \\
(\mathrm{kJ} / \mathrm{kg})\end{array}$ & Area $\mathrm{km}^{2}$ \\
\hline NW fault & 49.7 & 0.0 & $37.1 \%$ & $0.0 \%$ & - & 5.7 \\
\hline SW fault & 48.5 & 0.0 & $36.2 \%$ & $0.0 \%$ & - & 5.7 \\
\hline IFF & 0.0 & 2.3 & $0.0 \%$ & $1.7 \%$ & 1473 & 0.1 \\
\hline PFF & 0.0 & 9.4 & $0.0 \%$ & $7.0 \%$ & 1401 & 0.2 \\
\hline CFF & 0.0 & 33.1 & $0.0 \%$ & $24.6 \%$ & 1505 & 0.2 \\
\hline Fractured Reservoir & 0.0 & 60.9 & $0.0 \%$ & $45.3 \%$ & 1478 & 4.5 \\
\hline Basement Greywacke & 0.0 & 10.7 & $0.0 \%$ & $8.0 \%$ & 1525 & 1.7 \\
\hline Rotokawa Andesite & 0.0 & 4.1 & $0.0 \%$ & $3.1 \%$ & 1465 & 1.3 \\
\hline Reservoir Boundary & 0.6 & 12.1 & $0.5 \%$ & $9.0 \%$ & 1519 & 4.7 \\
\hline Background Rock & 35.3 & 1.8 & $26.3 \%$ & $1.4 \%$ & - & 176.0 \\
\hline Total & 134.1 & 134.4 & - & - & - & 200 \\
\hline
\end{tabular}

Table 6: Vertical mass flow rate across -3000mRSL layer showing the upflow into the base of the reservoir. 
Upflow below the field is concentrated within the $3 \Omega-\mathrm{m}$ contour $(5.2 \mathrm{~kg} / \mathrm{s} / \mathrm{km} 2)$ as this has the largest vertical permeability. However, there is still a large flow rate within the $50 \mathrm{hm}$ contour $(2.2 \mathrm{~kg} / \mathrm{s} / \mathrm{km} 2)$ and the deep fractured zone $\left(0.99 \mathrm{~kg} / \mathrm{s} / \mathrm{km}^{2}\right)$. The deep fractured zone contains the majority of both upflow and downflow showing the high temperature convection occurring in this zone. The same inverse relationship between upflow temperature and vertical permeability is shown in the mass flow across the $-4000 \mathrm{mRSL}$ layer as the highest enthalpy fluid is up flowing within the Deep Fractured Zone $(1.5 \mathrm{mD} \mathrm{k})$, followed by the $5 \Omega \mathrm{m}(2 \mathrm{mD})$ and then the $3 \Omega \mathrm{m}(3 \mathrm{mD})$.A smaller portion of the downflow takes place within the two faulted zones outside the field in the $-4000 \mathrm{mRSL}$ layer then in the $-3000 \mathrm{mRSL}$ layer.

\begin{tabular}{|c|c|c|c|c|c|c|}
\hline \multicolumn{7}{|c|}{ Model Vertical Mass Flow Rates at -4000mRSL } \\
\hline Rock Type & $\begin{array}{c}\text { Downflow } \\
\text { rate }(\mathrm{kg} / \mathrm{s})\end{array}$ & $\begin{array}{c}\text { Upflow Rate } \\
(\mathrm{kg} / \mathrm{s})\end{array}$ & \% Downflow & \% Upflow & $\begin{array}{c}\text { Upflow } \\
\text { Enthalpy } \\
(\mathrm{kJ} / \mathrm{kg})\end{array}$ & $\begin{array}{c}\text { Area } \\
\mathrm{km} 2\end{array}$ \\
\hline NW fault & 37.2 & 0.0 & $22.0 \%$ & $0.0 \%$ & - & 5.7 \\
\hline SW fault & 35.9 & 0.0 & $26.8 \%$ & $0.0 \%$ & - & 5.7 \\
\hline $3 \Omega$ m Contour & 1.5 & 46.3 & $1.1 \%$ & $34.5 \%$ & 1422 & 8.9 \\
\hline $5 \Omega$ m Contour & 8.5 & 48.5 & $6.3 \%$ & $36.1 \%$ & 1458 & 21.7 \\
\hline Deep Fractured Zone & 85.1 & 73.5 & $63.4 \%$ & $54.7 \%$ & 1577 & 74.5 \\
\hline Background Rock & 1.0 & 0.5 & $0.7 \%$ & $0.4 \%$ & - & 83.5 \\
\hline \hline Total & 169.1 & 168.9 & - & - & - & 200 \\
\hline
\end{tabular}

Table 7: Vertical mass flow rate across -4000mRSL layer showing the upflow within the high temperature convection below the reservoir.

\section{Super Critical Convection}

In the RK38 model the Supercritical temperature reach depth shallower than $-4500 \mathrm{~m}$. The contour of super critical temperature can be seen in Figure 46 below. Similar temperature contours plots of 350, 330 and $310 \mathrm{C}^{\circ}$ can be seen in appendix B.1.4 -B.1.6. The supercritical convection an occurs predominantly in the $1 \mathrm{mD}$ vertical convection in the fractured reservoir rock and is not located directly below the reservoir. The $5 \Omega \mathrm{m}$ contour has a $1.5 \mathrm{mD}$ vertical permeability and $3 \Omega \mathrm{m}$ has $2 \mathrm{mD}$ vertical permeability. A slice at of vertical permeabilities $-5000 \mathrm{mRSL}$ can be seen Figure 45 . Deep temperature contours are correlated with the lower vertical permeability zone in the deep fractured rock as oppose to the slightly higher vertical permeabilities in the $3 \Omega \mathrm{m}$ and $5 \Omega \mathrm{m}$ resistivity contours.

The deep convection area was significantly larger than the reservoir size. In this model the area taken by the reservoir was $\sim 105 \mathrm{~km}^{2}$ extending from $-4000 \mathrm{mRSL}$ to $-6000 \mathrm{mRSL}$. The Rotokawa reservoir boundaries are $\sim 15-18 \mathrm{~km}^{2}$ at $-3000 \mathrm{mRSL}$ in RK38 there was reservoir permeability of $12.6 \mathrm{~km}^{2}$ at -3000 . In model RK38 there was a convection cell over $5 x$ the area below the reservoir to allow sufficient convection rates into the reservoir. 


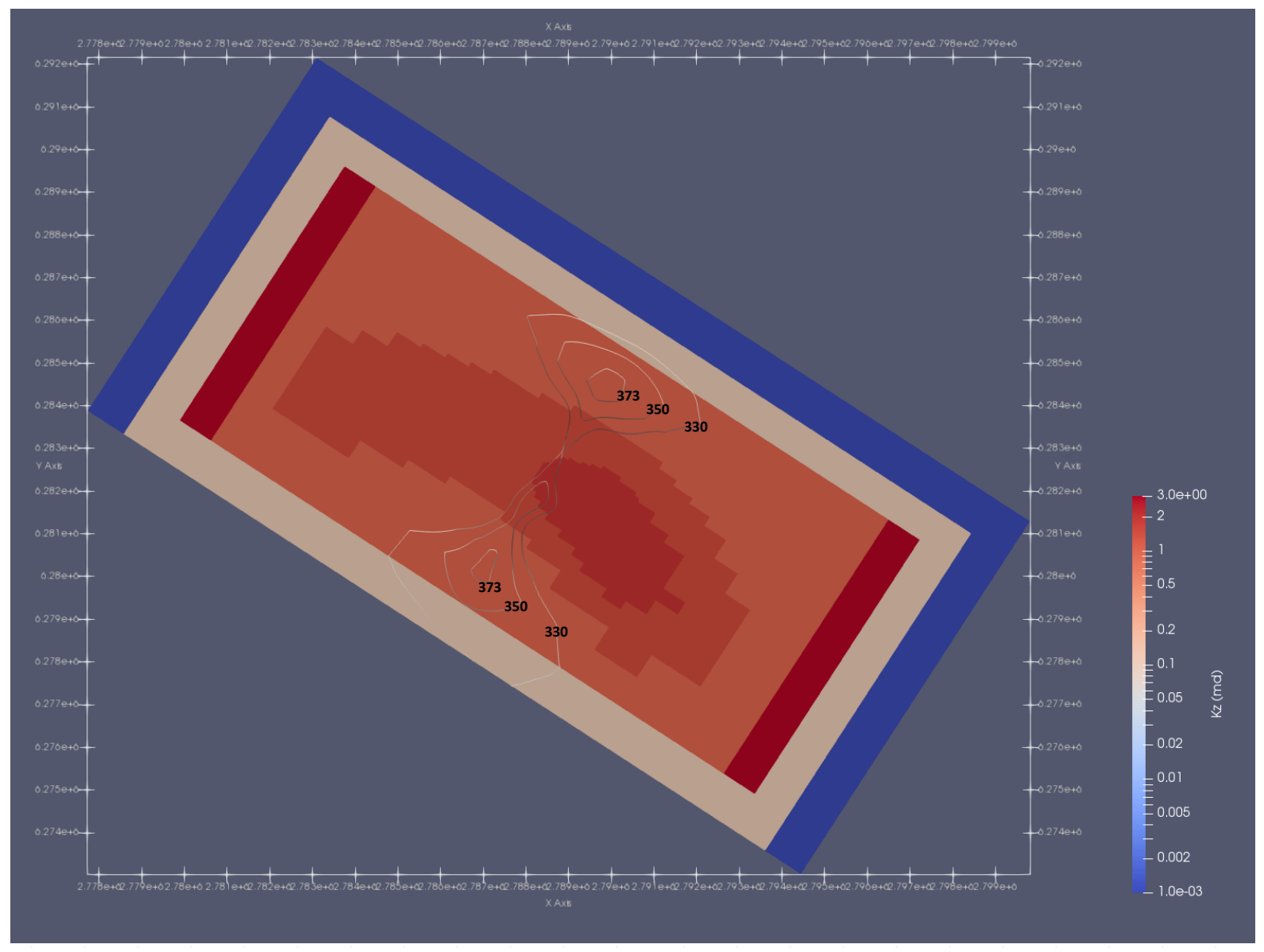

Figure 45: -5000mRSL vertical permeability $\left(k_{z}\right)$ slice with 373,350 , and $330^{\circ} \mathrm{C}$ temperature contours. 


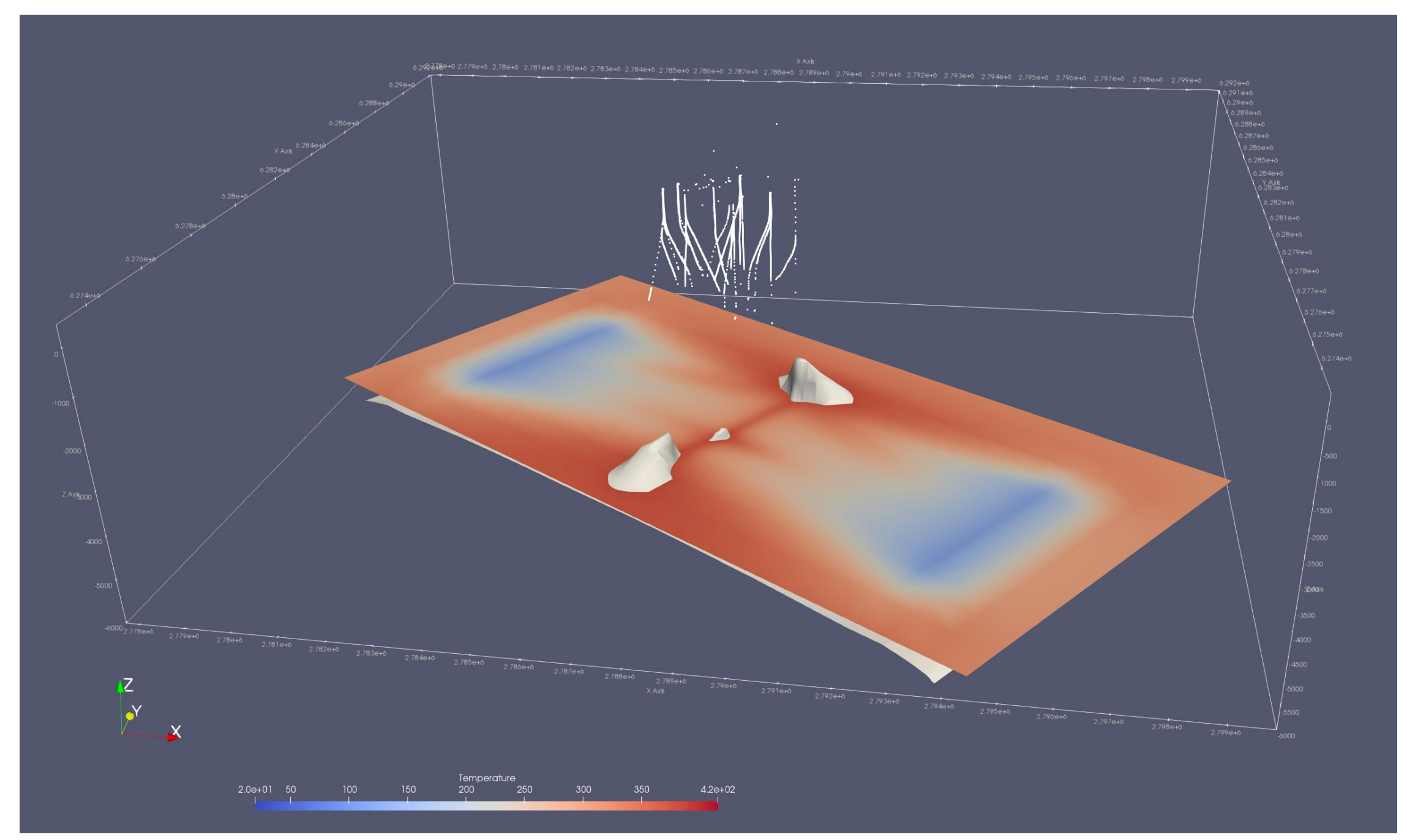

Figure 46: RK38 373C contour showing extend of supercritical convection. A-5500mRSL temperature slice is shown intercepting the temperature contour. In natural state convection the super critical temperatures reached depth shallower than -4500 . 


\section{Chapter 6: Discussion}

\section{Fault Process model}

The single fault process model is a simplified way to isolate variables in that will be implemented into the Rotokawa numerical model. The Rotokawa model will require both a large vertical flow rate into the reservoir at -4000 to $-3500 \mathrm{mRSL}$ in addition to an upflow of $\sim 150 \mathrm{~kg} / \mathrm{s}$ with a fluid enthalpy of $\sim 1500$ $\mathrm{kJ} / \mathrm{kg}$ will be needed to provide the heat flow into the reservoir.

Enthalpy is a result of the fluid temperature and pressure as the model is entirely compressed liquid. So, the temperature and pressure will be directly correlated (Figure 32). The heat flow will also be almost entirely convection when the fault is above permeabilities to allow convection so the mass flow and heat flow are also directly correlated (Figure 33). As a result, the mass flow rate and temperature will be show for simplicity.

In the deep layer (-6000mRSL) the models show lower permeabilities (as long as they allow convection) allow higher temperature convection in the fault but decrease the flow rate within the fault (Figure 31 ,Figure 34 , and Figure 35). The $1 \mathrm{mD}$ vertical permeability was found to be the most critical parameter for convection temperature (Figure 34 ) as the $1 \mathrm{mD} \mathrm{k}_{\mathrm{v}}$ and $10 \mathrm{mD} \mathrm{k}_{\mathrm{h}}$ model allowed the highest temperature in all the fault process models.

The fault area and permeabilities had the largest effect on the faults flow rate. The fault however only had less of a decrease in convection temperature than increaseing the fault permeability to increase mass flow. In order to create a natural state temperature and pressures in the field a large area 'fault' likely a large deformed and fractured area as a result of caldera collapse or other complex stress interaction in the crust. with a low vertical permeability will be required below the field. This will be included into the Rotokawa geothermal system model.

Additionally, specific heat, porosity, rock density, rain fall and conductivity (if kept within realistic limits) all did not have an effect on the natural state convection of the fault (Appendix B.2.2-B.2.6). At conductivities below 1 there was very low temperatures and

\section{Rotokawa Geothermal System Model}

The result show that temperature, pressure and upflow rates can be roughly matched from a purely convection model with $415^{\circ} \mathrm{C}$ base at $-6000 \mathrm{mRSL}$. Higher mass flow rates within the fault were inversely proportional to convecting fluid temperature as seen in the IFF, PFF and CFF upflow enthalpy (Table 7).

Two challenges when modeling was getting enough mass flow to provide the needed heat flow into the geothermal reservoir. Secondly getting high fluid convection temperature. The difficulty being the high flow rates and high temperatures are inversely related in the fault process model.

The system that allowed both of these aspects in the model was large area low permeable convection system. At $-3500 \mathrm{~m}$ higher fault permeabilities create areas for upflow of the high-temperature convection fluid into the system. Downflow has to be predominantly outside of the geothermal system connected laterally to the low permeable convection allow for sufficient up flow rates. The different convection cells can be seen well in figure 
The Rotokawa geothermal system reservoir modeling had similar up flow enthalpy and the max upflow enthalpy reached $1577 \mathrm{~kJ} / \mathrm{kg}$ within the basement greywacke at $-3000 \mathrm{mRSL}$.

\begin{tabular}{|c|c|c|c|c|c|}
\hline \multicolumn{6}{|c|}{ Comparison of Natural State Reservoir Models } \\
\hline Model & Year & $\begin{array}{c}\text { Base Depth } \\
(\mathrm{mRSL})\end{array}$ & $\begin{array}{c}\text { Base } \\
\text { Injection } \\
\text { Rate }(\mathrm{kg} / \mathrm{s})\end{array}$ & $\begin{array}{c}\text { Injection } \\
\text { Enthalpy }(\mathrm{kJ} / \mathrm{kg})\end{array}$ & $\begin{array}{c}\text { Base Temperature } \\
\left({ }^{\circ} \mathrm{C}\right)\end{array}$ \\
\hline Hernandez et al. & 2015 & -4100 & 150 & 1500 & 330 \\
\hline Boyer and Holt & 2010 & -4250 & 105 & 1600 & 330 \\
\hline $\begin{array}{c}\text { Rotokawa Reservoir } \\
\text { System Model }\end{array}$ & Year & $\begin{array}{c}\text { Base Depth } \\
\text { (mRSL) }\end{array}$ & $\begin{array}{c}\text { Upflow at } \\
-4000(\mathrm{~kg} / \mathrm{s})\end{array}$ & $\begin{array}{c}\text { Upflow Enthalpy } \\
\text { at-4000 (kJ/kg) }\end{array}$ & \\
\hline Carson & 2018 & -6000 & 169 & 1500 & 415 \\
\hline
\end{tabular}

Table 8: Model RK38 showing similar upflow rate and upflow enthalpy for previous Rotokawa reservoir models.

In the model down flow occurred predominantly in the faults outside of the model. This was expected as the fault were put in the conceptual model to allow downflow into the system $73 \%$ at $-3000 \mathrm{mRSL}$ and $49 \%$ at $-4000 \mathrm{mRSL}$. At $-4000 \mathrm{mRSL}$ very little recharge $(0.7 \%)$ occurred in the background rock suggesting faulting or anther high permeable structure is necessary outside the field for sufficient down flow rates deep into the convection system. At $-3000 \mathrm{mRSL}$ only $26 \%$ of downflow occurred in the background rock.

\section{Challenges of Drilling into Super Critical Reservoirs}

Drilling for supercritical reservoir needs be economic. Drilling costs will increase as the depth of the targeted formation deepens. Shallower feed zones may need to be cased off and isolated to target deeper depths. They could re-perforated to be accessed but this takes on both the perforation cost and more risk. The lower permeabilizes may provide better wellbore stability but challenges with corrosion of drill pipe and the BHA are likely as mentioned in the IDDP-1 project.

Several drilling issues arose while researching the drilling into supercritical geothermal reservoirs. As is common in geothermal wells, especially in highly fractured reservoirs, wells were drilled with total circulation loss, and sometimes a very low rate of penetration (ROP) and high bit wear. Additionality problems arose due to additives to the drilling fluid. Due to additives to the drilling fluid sometimes coagulated, blocking the drill string and eventually leading to stuck pipe. Due to the high temperatures and acidic reservoir fluids, drill string fatigue and corrosion was observed, sometimes leading to breakage (Gunnlaugsson et al., 2014; Miller 1980; Sanada et al., 1998) and Consequently fishing, and eventually side tracking, was performed. Often, cementing a casing across high permeability fractures is necessary. The high-temperature environment also affects cement setting kinetics and can lead to cement-job failures. To be able to economically access and to sustainably utilize supercritical geothermal systems, improved drilling, completion, and cementing practices have to be implemented. Completion components have to be able to handle high temperatures and pressures and acidic environments. Monitoring of subsurface conditions by measurements while drilling (MWD) can help to predict critical zones and conditions. Scaling and erosion processes have to be considered. Once a well is completed, logging and monitoring instruments have to be capable of operating at ambient downhole conditions.

The supercritical zones having low permeability modeled is consistent with a study of all geothermal exploration wells drilled to date given by Reinsch et al. (2017) with for most of the wells where supercritical conditions were encountered, permeable zones were observed at depths and an inflow 
could be measured. For wells that encountered a magmatic intrusion, fluid emanated from the zone surrounding the magma layer, likely in a brittle state. For sites without recent intrusion, where proximity to a larger (solidifying) magma body can be assumed to be the heat source, observed permeabilities are often lower (e.g., at Kakkonda, Japan or Los Humeros, Mexico). Here, EGS-type concepts have to be considered, including stimulation technologies, thermally or hydraulically. Different stress regimes and rock types may impact the ability to create and sustain open fractures under supercritical conditions. (Reinsch et al., 2017)

Exploration technology that still needs to be developed include geophysical exploration methods, field stress measurements, high-temperature geothermometers and high-temperature tracer tests. Drilling and Completions technology that needs to be developed includes improved drilling methods for hightemperature systems and improved well completion methods for high-temperature systems and surface equipment also need to be have capabilities for scrubbing and fluid-handling strategies for dealing with supercritical fluids and corrosive gases and optimized designs for surface fluid handling, power conversion, and cooling systems for supercritical fluids

Looking simplicity at Darcy's equation two factors stand out that will drive fluid into the wellbore at higher rates than expected within the lower permeability supercritical zones. The high enthalpy fluid will have a lower BHP as the density of the column will be significantly less as the pressure drop the steam fraction will be higher than that of a high temperature compressed liquid well at $300^{\circ} \mathrm{C}$ for example. This creates a much larger pressure differential between the downhole pressure and the reservoir pressure, at the simulated depths Additional as seen in Figure 47 , The viscosity of water in most high temperature fields in $\mathrm{NZ}\left(300^{\circ} \mathrm{C}\right)$ will be around $90 \mu \mathrm{P}$ a-s, while once this fluid reaches supercritical conditions the viscosity will reach around $30 \mu \mathrm{P}$ a-s. Note that viscosity is pressure dependent and at 4500 to $-5000 \mathrm{~m}$ the pressure would be around 45- $50 \mathrm{Mpa}$ at the depths simulated for supercritical temperatures.

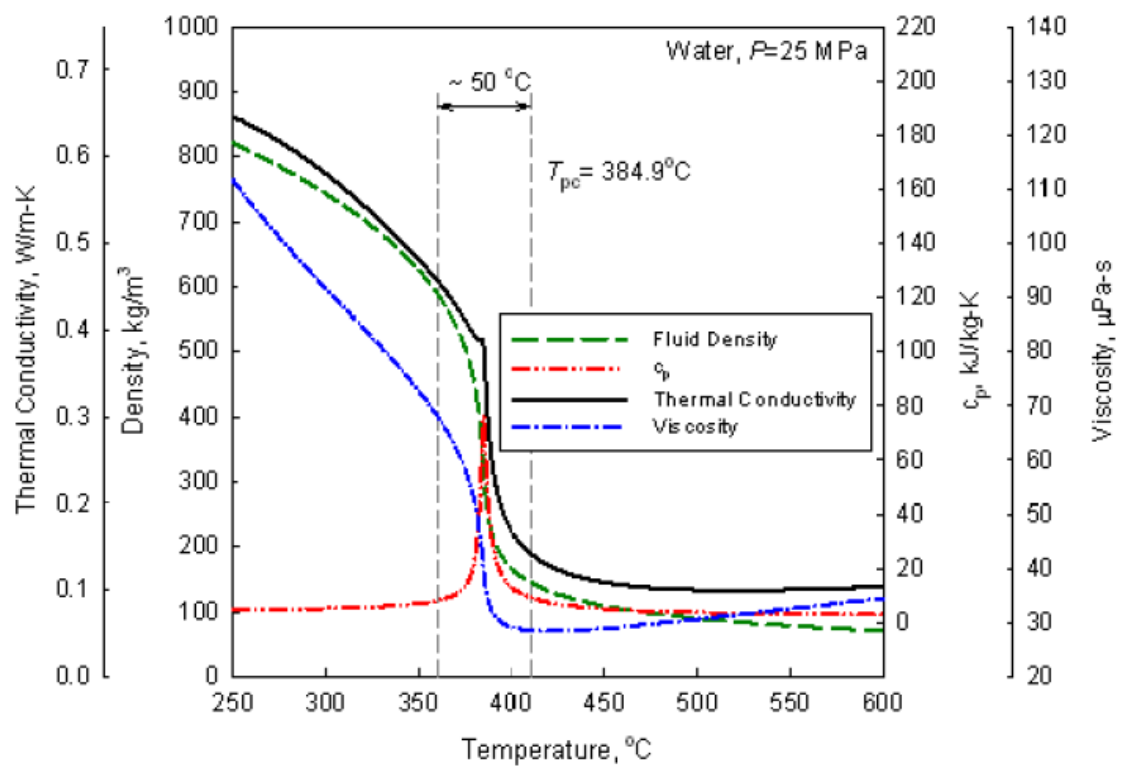

Figure 47: Thermophysical properties of supercritical water within pseudocritical range. (Gupta et al., 2010) 
Additionally, New Zealand has both highly permeable and high enthalpy wells. In comparison this makes the net present value of a supercritical geothermal well unattractive given the risks. However, if enthalpy decline in the field is significant it may be more cost effective to incorporate one super critical well to maintain the required plant enthalpy instead of modifying the surface infrastructure for the lower enthalpy field. Additionally, increased demand for renewable will need to balance intermittent forms of renewable energy and a large demand of base load capacity that geothermal provides will be needed to the current fossil fuels used in power generation.

\section{Chapter 7: Conclusion}

The fault process model allowed a sensitivity analysis of many of the TOUGH 2 rock properties and boundary conditions. The process model found that changes to the fault permeability and vertical to horizontal permeability ratio were the most sensitive parameters for fluid enthalpy (fault temperature) and mass flow (energy flow). The fault area was also sensitive to increasing mass flow with less temperature decrease. Increases in fault permeability resulted a decrease in the convection temperature. The highest simulated temperature in the fault process model was a result of a $1 \mathrm{mD}$ vertical fault with a $10 \mathrm{mD}$ horizontal permeability.

The fault process model suggested that low vertical permeability, with a higher horizontal permeability and a large area "fault" is the best way to for high enthalpy convection from the BDT to occur into the Rotokawa reservoir with a sufficient upward mass flow. This large deformed area that is necessary for high enthalpy convection is likely a result of complex stress interaction below the crust and may be associated with past caldera collapse events.

A Rotokawa geothermal system model was successfully matched natural state Rotokawa temperature and pressure below the clay cap. The mass upflow rates and fluid enthalpy of previously Rotokawa reservoir models.

There are six major components of the high temperature convection system that were modeled as shown and labeled previously in Figure 43.

1. Meteoric water down flow through the high vertical permeable fault zones outside the reservoir to the NW and SE. $40-80 \%$ of the down flow comes through these zones depending on the layer. This allows recharge into the convection system.

2. The upflow beginning at the base travels predominantly in the highest vertical permeability path way. The $3 \Omega \mathrm{m}$ contour as well as the $5 \Omega \mathrm{m}$ contour zones had the most upflow below the reservoir. However, the highest enthalpy occurs in the lower vertical permeability zones as long as the heat transfer does not transition to conduction (if the permeability is too low to allow convection).

3. High temperature $\left(340^{\circ} \mathrm{C}+\right)$ convection zone. High temperature convection occurs in the region of low vertical permeability below the reservoir $\left(5 \mathrm{mD} \mathrm{k}_{\mathrm{h}}\right.$ and $\left.0.5-2 \mathrm{mD} \mathrm{k}_{\mathrm{v}}\right)$. The flow is mostly lateral until it reaches the $3 \Omega \mathrm{m}$ and $5 \Omega \mathrm{m}$ zones.

4. The transition from low permeability deep zone to the reservoir. This was primarily bounded by the mircoseismicity data (MEQ events). Where the MEQ events terminate it is assumed to be where the vertical permeability terminates also. This is interpreted as the base of the reservoir. 
5. Upflow into the reservoir from reservoir faults, primarily the CFF in this model. The fault penetrated the high temperature convection system and is a very high vertical permeability allowing a large mass flow rate up the CFF.

6. Outflow of the Rotokawa geothermal reservoir from the primary reservoir to surface in the north of the field. With an impermeable clay cap preventing downflow into the field.

An important finding is the highest temperature up flows may not be in high permeability fault structures. To reach supercritical geothermal fluids (without shallow magmatic intrusions seen in dike systems like Iceland) the permeability may be much lower closer to a conduction system seen at the edge of a geothermal field. The supercritical fluid will have both a much higher enthalpy, of greater than $3200 \mathrm{~kJ} / \mathrm{kg}$ at (taken from steam tables) but will have a significantly decrease viscosity and a high reservoir pressure.

The size of the super critical convection will likely correlate with the area and the ability of the intercepting vertical permeable pathway (CFF in Rotokawa) to allow fluid to flow upward into the reservoir. This supercritical convection may be imaged from large-scale MT surveys as seen in Bertrand et al., 2015. Using this method MT contour gave a reasonable match to natural state.

Super critical temperatures may not be located directly below the reservoir are not necessarily correlated with the higher vertical permeability zones as seen in Figure 45 . The supercritical temperatures did reach $-4500 \mathrm{mRSL}$ in this model as seen in the temperature contour in Figure 46 . As previously addressed besides the mass flow from a supercritical system the potential corrosion is another major issue that will need to be addressed to harness this resource.

\section{Limitations of Work}

The are some limitations from with this modeling work. Firstly, the reservoir data that is typically available to the reservoir modeler was not provided from the geothermal operating company. This data typically includes pressure temperature and velocity spinner, well test (injection, pressure builds, pressure fall off) geochemistry, and geologic (core, and cuttings analysis) and geophysical data (MT, microseicmic, gravity). Despite this limitation sufficient information could be gathered from literature to complete the project.

Due to the scale of the reservoir model large grid blocks had to be used. This severely limits the resolution of the reservoir model. Shallow features such as the Waikato river or intermediate aquifers that were incorporated into Hernandez's model cannot be put into the model. This can be seen in the shallow temperature match in Figure 39. Although the objective was to match reservoir temperatures, shallow temperatures were only a secondary objective in this project.

Finally modeling an unconstrained area below the reservoir. A simple approach was taken based off the vertical MT slices from. but the actual permeable structure could be different from the MT data. The permeability and areas required to provide the temperature and upflow will remain similar, unless major changes to the deep conceptual model are made.

\section{Future Work}

Additional work includes building a well bore coupled supercritical numerical process model. The objective being to simulate the deliverability of an exploration supercritical well given the rock properties modeled in this research. Existing wellbore model could be modified and coupled to the 
supercritical TOUGH2 code to achieve this. This work would be essential for a geothermal operator to model before undertaking a deep drilling project to prove the net present value of the project would be enough to account for the high-risk exploration project. Although the bulk permeabilities of the supercritical convection zone may be low compared to current reservoir permeabilities, the lower viscosity supercritical fluid and the high pressure of the reservoir may still have sufficient mass flow of high enthalpy fluid to make the well economic. 


\section{Appendix A}

\section{A.1 General Equations}

Darcy's law describes flow through porous media.

$$
\frac{Q}{A}=\frac{k}{\mu} \frac{\Delta P}{\Delta L}
$$

Q: Flow rate

A: cross sectional area, $\pi r^{2}$

k: permeability

$\mu$ : viscosity

$P$ : pressure, $\Delta P=P_{2}-P_{1}$

L: length

Figure shows a simplified image of variable denoted.

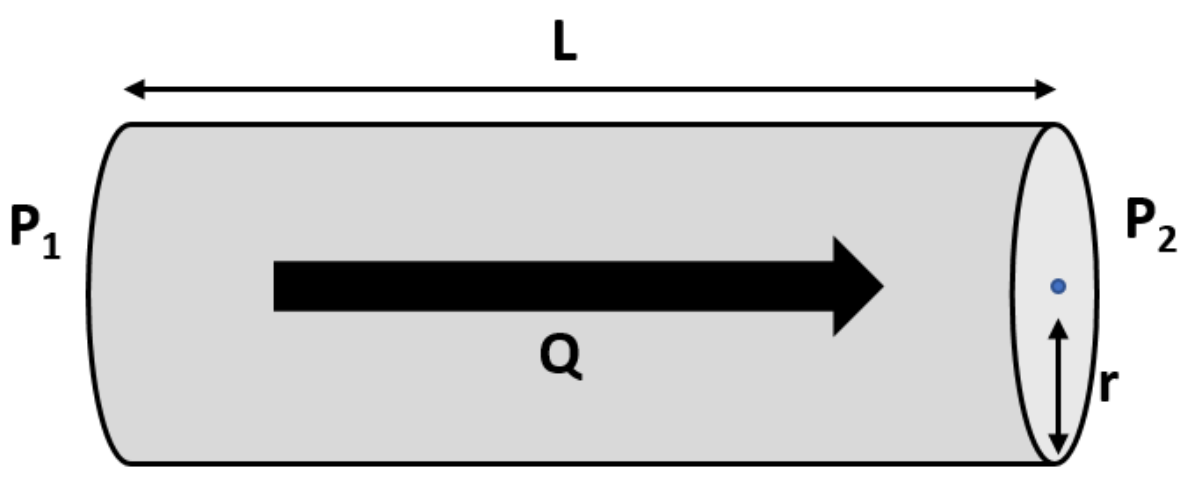

\section{A.2. Tough2 Equations}

The material and energy balance equations solved by TOUGH2 can be written in general form $V_{n}$

$$
\frac{d}{d t}=\int_{V_{n}} M^{\kappa} d V_{n}=\int_{\Gamma_{n}} F^{\kappa} n d \Gamma_{n}+\int_{V_{n}} q^{\kappa} d V_{n}
$$

The integration is over an arbitrary sub domain $V_{n}$. This denotes the flow system, bounded by the closed surface $\Gamma_{\mathrm{n}}$.

M: The accumulation term Mass or energy per volume 
$\kappa: 1, \ldots$, NK labeling the mass components (water) and $\mathrm{K}=\mathrm{NK}+1$ denoting the heat component.

F: Mass or heat flux.

Q: Sinks and sources

$\mathrm{N}$ : A normal vector to $\mathrm{d} \Gamma_{\mathrm{n}}$ pointing inward into $V_{\mathrm{n}}$

The general form of the Mass accumulation term is

$$
\mathrm{M}^{\mathrm{K}}=\Phi \sum_{\beta} \mathrm{S}_{\beta} \rho_{\beta} \mathrm{X}_{\beta}^{\mathrm{K}}
$$

The total mass component $\kappa$ obtained by summing all of the fluid phases $\beta$. This is the liquid, gas and non- aqueous phase liquid.

$\Phi:$ Porosity

$S_{\beta}$ : Saturation of phase $\beta$. This is the fraction of pore volume occupied by $\beta$.

$\rho_{\beta}$ : Density of phase $\beta$

$\mathrm{X}_{\beta}{ }^{\mathrm{K}}$ : Mass fraction of component $\mathrm{k}$ present in phase $\beta$.

The Heat accumulation term for a multiphase system is

$$
\mathrm{M}^{\mathrm{NK}+1}=(1-\phi) \rho_{R} C_{R} T+\phi \sum_{\beta} \mathrm{S}_{\beta} \rho_{\beta} u_{\beta}
$$

$\rho_{R}$ : Grain Density of the rock

$C_{r}$ : Specific heat of the rock

T: Temperature

$\mathrm{u}_{\beta}$ : Specific internal energy in Phases $\beta$

The advective mass flux is the sum over phases,

$$
\mathrm{F}^{\mathrm{K}} \mid \mathrm{adv}=\sum_{\beta} \mathrm{X}_{\beta}^{\mathrm{\kappa}} F_{\beta}
$$

Individual phases fluxes are given by multiphase version of Darcy's Law.

$$
\mathrm{F}_{\beta}=\rho_{\beta} \mathrm{u}_{\beta}=-\mathrm{k} \frac{\mathrm{k}_{\mathrm{r} \beta} \rho_{\beta}}{\mu_{\beta}}\left(\nabla \mathrm{P}_{\beta}-\rho_{\beta} \mathrm{g}\right)
$$

$\mathrm{u}_{\beta}$ : Darcy Velocity (volume flux) in phase $\beta$ 
k: absolute permeability

$\mathrm{k}_{\mathrm{r} \beta}$ : Relative Permeability to phase $\beta$,

$\mu_{\beta}$ : viscosity

$$
\mathrm{P}_{\beta}=\mathrm{P}+\mathrm{P}_{\mathrm{c} \beta}
$$

$P_{\beta}$ : Fluid pressure in phase $\beta$

$P_{c \beta}$ : Capillary pressure $(\leq 0)$.

$\mathrm{P}:$ A reference phase (typically the gas phase)

$\mathrm{g}$ : The vector of gravitational acceleration.

Heat flux includes both conductive and convective components.

$$
\mathrm{F}^{\mathrm{NK}+1}=-\lambda \nabla \mathrm{T}+\sum_{\beta} \mathrm{h}_{\beta} \mathrm{F}_{\beta}
$$

$\lambda$ : Thermal conductivity

$h_{\beta}$ : Specific enthalpy in phase $\beta$

Relative gas permeability changes with pressure so a correction needs to be applied. Absolute permeability can be calculated is of the gas phase pressure follows the relationship given by Klingenberg (1941).

$$
k=k_{\infty}\left(1+\frac{b}{P}\right)
$$

$\mathrm{k}_{\infty}$ : Permeability at "infinite pressure"

b: Klinkenberg parameter

In addition to Darcy Flow, mass transport can also occur by diffusion and hydrodynamic dispersion as follows (de Marisly, 1986)

$$
F^{\kappa} \mid d i s=-\sum_{\beta} \rho_{\beta} \bar{D}_{\beta}^{\kappa} \nabla X_{\beta}^{\kappa}
$$

The hydrodynamic dispersion tensor is given by

$$
\bar{D}_{\beta}^{\kappa}=D_{\beta, T}^{\kappa} \overline{\mathrm{I}}+\frac{\left(D_{\beta, \mathrm{L}}^{\kappa}-D_{\beta, T}^{\kappa}\right)}{u_{\beta}{ }^{2}} u_{\beta} u_{\beta}
$$

where 


$$
\begin{aligned}
& \bar{D}_{\beta, \mathrm{L}}^{\kappa}=\phi \tau_{0} \tau_{\beta} \mathrm{d}_{\beta}^{\kappa}+\alpha_{\beta, \mathrm{L}} \mathrm{u}_{\beta} \\
& \overline{\mathrm{D}}_{\beta, \mathrm{T}}^{\kappa}=\phi \tau_{0} \tau_{\beta} \mathrm{d}_{\beta}^{\kappa}+\alpha_{\beta, \mathrm{T}} \mathrm{u}_{\beta}
\end{aligned}
$$

The diffusion coefficient for gasses depens on pressure and temperature as (Vargaftik,1975; Walker er al., 1981).

$$
d_{\beta}^{\kappa}(P, T)=d_{\beta}^{\kappa}\left(P_{0}, T_{0}\right) \frac{P_{0}}{P}\left[\frac{T+273.15}{273.15}\right]^{\theta}
$$

At standard conditions of $\mathrm{P}_{0}=1 \mathrm{~atm}=1.10325 \mathrm{bar}, \mathrm{T}_{0}=0{ }^{\circ} \mathrm{C}$, the diffusion coefficient for vapor- air mixtures have a value of $2.13 \times 10^{-5} \mathrm{~m}^{2} / \mathrm{s}$. Parmenter $\theta$ for the temperature dependence is 1.80 .

\section{A.2.2. Space and Time Discretization}

The continuum equations are discretized in space using the integral finite difference method. Introducing volume averages, we have

$$
\int_{V_{n}} M d V=V_{n} M_{n}
$$

M: A volume-normalize normalized extensive quantity

$M_{n}$ : Average value of $M$ over $V_{n}$.

Surface integrals are approximated as a discrete sum of averages over surface segments $A_{n m}$.

$$
\int_{\Gamma_{\mathrm{n}}} \mathrm{F}^{\mathrm{K}} \bullet \mathrm{n} \mathrm{d} \Gamma=\sum_{\mathrm{m}} \mathrm{A}_{\mathrm{nm}} \mathrm{F}_{\mathrm{nm}}
$$

$F_{n m}$ : Average value of the normal component of $F$ over the surface segment Anm between volume elements $\mathrm{V} n$ and $\mathrm{Vm}$
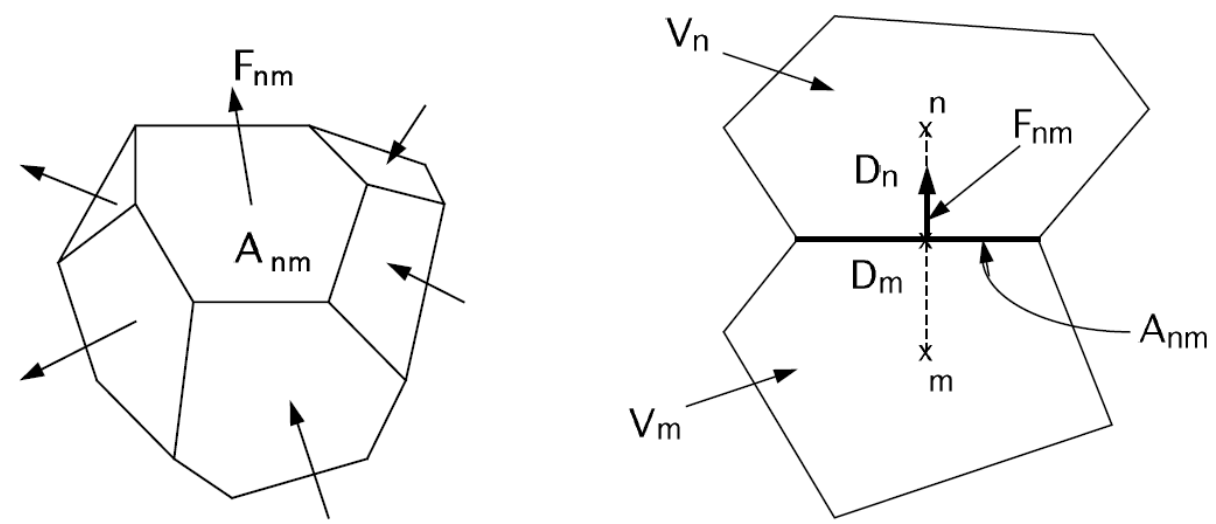

Fig. Space Discretization and geometry data in the integral finite difference method. (Moridis and Pruess, 1998) 
The discretized flux is expressed in terms of averages over parameters for elements $\mathrm{Vn}$ and $\mathrm{Vm}$. For we have.

$$
\mathrm{F}_{\beta, \mathrm{nm}}=-\mathrm{k}_{\mathrm{nm}}\left[\frac{\mathrm{k}_{\mathrm{r} \beta} \rho_{\beta}}{\mu_{\beta}}\right]_{\mathrm{nm}}\left[\frac{\mathrm{P}_{\beta, \mathrm{m}}-\mathrm{P}_{\beta, \mathrm{m}}}{\mathrm{D}_{\mathrm{nm}}}-\rho_{\beta, \mathrm{nm}} \mathrm{gnm}_{\mathrm{nm}}\right]
$$

subscripts $(\mathrm{nm})$ denote a suitable averaging at the interface between grid blocks $\mathrm{n}$ and $\mathrm{m}$ (interpolation, harmonic weighting, upstream weighting).

$D_{n m}$ : Distance between the nodal points $n$ and $m$

$\mathrm{g}_{\mathrm{nm}}$ : Component of gravitational acceleration in the direction from $\mathrm{m}$ to $\mathrm{n}$

Space discretization of diffusive flux

$$
\left(\mathrm{f}^{\kappa}\right)_{n m}=-\left(\sum_{l}^{\kappa}\right)_{n m} \frac{\left(X_{l}^{\kappa}\right)_{m}-\left(X_{l}^{\kappa}\right)_{n}}{D_{n m}}-\left(\sum_{g}^{\kappa}\right)_{n m} \frac{\left(X_{g}^{\kappa}\right)_{m}-\left(X_{g}^{\kappa}\right)_{n}}{D_{n m}}
$$

Where

$$
\sum_{\beta}^{\kappa}=\phi \tau_{0} \tau_{\beta} \rho_{\beta} d_{\beta}^{\kappa}
$$

Diffusive flux equation is re-written in terms of an effective multiphase diffusive.

$$
\left(\mathrm{f}^{\kappa}\right)_{n m}=-\left\{\sum_{l}^{\kappa}+\sum_{g}^{\kappa} \frac{\left(X_{g}^{\kappa}\right)_{m}-\left(X_{g}^{\kappa}\right)_{n}}{\left(X_{l}^{\kappa}\right)_{m}-\left(X_{l}^{\kappa}\right)_{n}}\right\}_{n m} \frac{\left(X_{l}^{\kappa}\right)_{m}-\left(X_{l}^{\kappa}\right)_{n}}{D_{n m}}
$$

Harmonic weighting of diffusive strength coefficients are required for the conservation of diffusive flux across the boundary between two adjacent blocks. Weighting of diffusive strength coefficients separately for liquid and gas phases is inadequate in some cases, for example, situations where phase partitioning effects occur. Thus, harmonic weighting is applied to the effective multiple diffusive strength coefficient which contains both liquid and gas diffusive strength coefficients.

\section{A.2.3. Calculation Procedure}

A set of first order ordinary differential equations in time

$$
\frac{d M_{n}^{\kappa}}{d t}=\frac{1}{V_{n}} \sum_{m} A_{n m} F_{n m}^{\kappa}+q_{n}^{\kappa}
$$

The time discretization results in the following set of coupled non-liner, algebraic equations

$$
R_{n}^{\kappa, k+1}=M_{n}^{\kappa, k+1}-M_{n}^{\kappa, k}-\frac{\Delta t}{V_{n}}\left\{\sum_{m} A_{n m} F_{n m}^{\kappa, k+1}+V_{n} q_{n}^{\kappa, k+1}\right\}=0
$$

Subscripts $k+1$ denotes the new time level, while subscript $k$ denotes the previous time level. The treatment of the unknown terms is fully implicit and numerical stability can be obtained.

These equations are solved by Newton/Raphson iteration. Expanding the residuals in a Taylor series, 


$$
R_{n}^{\kappa, k+1}\left(x_{i, p+1}\right)=R_{n}^{\kappa, k+1}\left(x_{i, p}\right)+\left.\sum_{i} \frac{\delta R_{n}^{\kappa, k+1}}{\delta x_{i}}\right|_{p}\left(x_{i, p+1}-x_{i, p}\right)+\cdots=0
$$

Subscript $p+1$ denotes the new iteration level, while subscript $p$ denotes the previous iteration level.

$\mathrm{x}_{\mathrm{i}}$ Primary variables

Retaining only terms up to first order,

For each volume element (grid block) $V_{n}$, there are NEQ equations

$$
N E Q=N K+1
$$

NK: The number of components

1 is added to include heat transfer.

Thus, for a flow system with NEL grid blocks, NEL*NEQ coupled non-linear equations exists.

There are NK1 primary variables for each volume element $\mathrm{V}_{\mathrm{n}}(1$ is added to include heat transfer), and totally NK1*NEL primary variables exists.

After determination of the primary variables, secondary parameters which consist of phase saturation, relative permeability, viscosity, density, specific enthalpy, capillary pressure, diffusion factor 1 , diffusion factor 2 are calculated. There are NB parameters needed for the accumulation and advective flow terms. $N B=8$ if diffusion factors are considered, otherwise $N B=6$. There are NK mass fractions of components in a phase. Thus in a phase, there are NBK $=\mathrm{NB}+\mathrm{NK}$ secondary parameters. In a block, total number of phases is NPH, so that there are NSEC $=\mathrm{NPH}^{*} \mathrm{NBK}+2$ secondary parameters. 2 is added to include temperature (miscellaneous). Due to the derivation of Residuals with respect to $x i$ is incremented, so, there are $(N E Q+1) *$ NSEC secondary parameters for each grid block $V_{n}$. Totally, there are NEL* $(N E Q+1)^{*}$ NSEC secondary parameters. Primary variables are taken from the previous run. Secondary parameters are calculated after the determination of the primary variables.

\section{A.2.4. Spatial Discretization}

Space discretization is made directly from the integral form of the basic conservation equations, without converting them into partial differential equations. The discretization results in a set of strongly coupled nonlinear algebraic equations, with the time-dependent primary thermodynamic variables of all grid blocks as unknowns

Additional methods are available to solve the linear equations at each iteration step. Preconditioned conjugate gradient solvers, as well as sparse direct matrix methods can be used. only through the application of iterative conjugate gradient methods that solutions for large grid systems $(10,000$ blocks or more) and three-dimensional problems can be accomplished (Moridis and Pruess, 1998).

Fluid flow is described by a multiphase extension of Darcy's Law. 


\section{Appendix B}

\section{B.1. Rotokawa Geothermal System Model}

B.1.1. Rotokawa Geothermal System Model Layers

The Rotokawa geothermal layers are shown in the table below.

\begin{tabular}{|c|c|c|}
\hline Layer & Top Elevation (mRSL) & Thickness (m) \\
\hline 1 & 350 & 100 \\
\hline 2 & 250 & 250 \\
\hline 3 & 0 & 100 \\
\hline 4 & -100 & 400 \\
\hline 5 & -500 & 500 \\
\hline 6 & -1000 & 500 \\
\hline 7 & -1500 & 500 \\
\hline 8 & -2000 & 500 \\
\hline 9 & -2500 & 500 \\
\hline 10 & -3000 & 500 \\
\hline 11 & -3500 & 500 \\
\hline 12 & -4000 & 500 \\
\hline 13 & -4500 & 500 \\
\hline 14 & -5000 & 500 \\
\hline 15 & -5500 & 100 \\
\hline 16 & -5600 & 100 \\
\hline 17 & -5700 & 100 \\
\hline 18 & -5800 & 100 \\
\hline 19 & -5900 & 100 \\
\hline Base & -6000 & - \\
\hline
\end{tabular}

B.1.2. Model RK38 Rock Type at Each Layer

All rocks of the layers are shown for model RK38 is shown below from the bottom elevation upward 

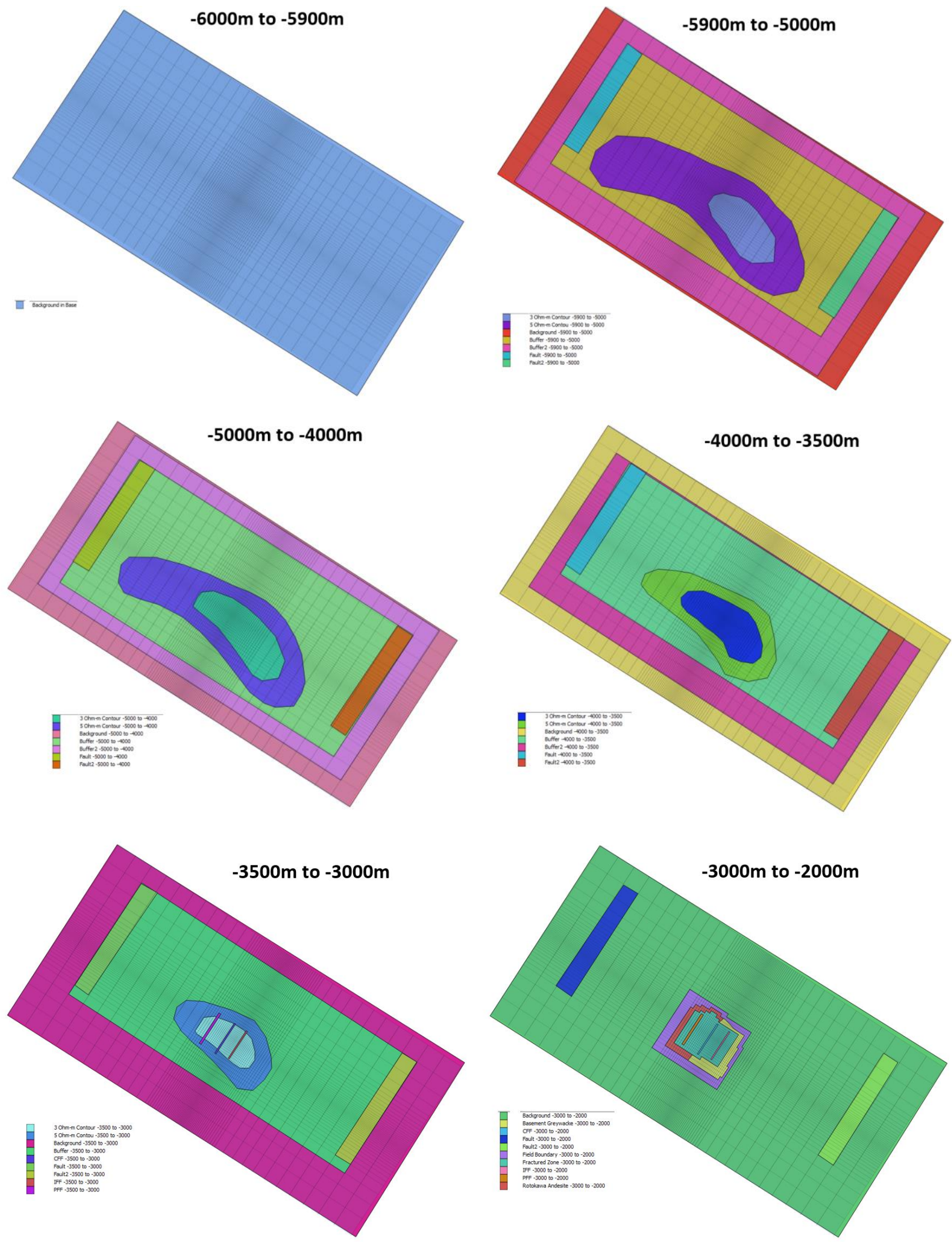

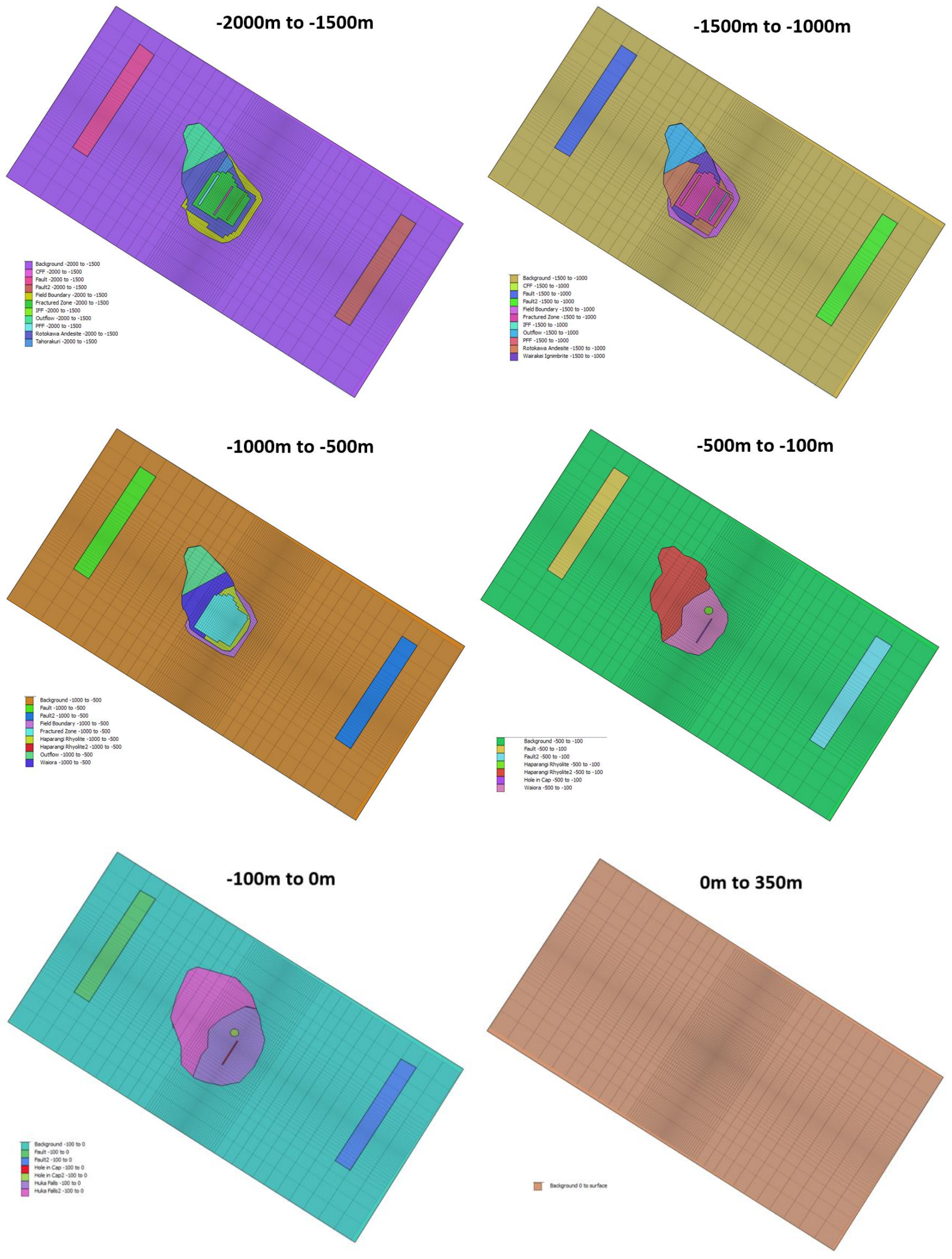
B.1.3. RK38 Model Rock Properties

\begin{tabular}{|c|c|c|c|c|c|c|c|c|}
\hline Long Name & Tough name & k1 & $\mathbf{k 2}$ & k3 & Porosity & Conductivity & Density & Specific Heat \\
\hline AIR01 & AIR01 & $1.00 \mathrm{E}-12$ & $1.00 \mathrm{E}-12$ & $1.00 \mathrm{E}-12$ & 0.9 & 0.3 & 1000 & 1000 \\
\hline Background in Base & BCK01 & $1.00 \mathrm{E}-20$ & $1.00 E-20$ & $1.00 \mathrm{E}-20$ & 0.01 & 2.5 & 2700 & $1.00 E+30$ \\
\hline Background -5900 to -5000 & BCKO2 & $5.00 \mathrm{E}-18$ & $5.00 \mathrm{E}-18$ & $1.00 \mathrm{E}-18$ & 0.03 & 2.5 & 2700 & 1000 \\
\hline $5 \mathrm{Ohm}-\mathrm{m}$ Contou -5900 to -5000 & INA01 & $5.00 \mathrm{E}-15$ & $5.00 \mathrm{E}-15$ & $1.50 \mathrm{E}-15$ & 0.2 & 2.5 & 2700 & 1000 \\
\hline 3 Ohm-m Contour -5900 to -5000 & INB01 & $5.00 E-15$ & $5.00 \mathrm{E}-15$ & $2.00 \mathrm{E}-15$ & 0.2 & 2.5 & 2700 & 1000 \\
\hline Buffer -5900 to -5000 & BUF01 & $3.00 \mathrm{E}-15$ & $3.00 \mathrm{E}-15$ & $1.00 \mathrm{E}-15$ & 0.10 & 2.5 & 2700 & 1000 \\
\hline Buffer2 -5900 to -5000 & BFO01 & $1.00 E-16$ & $1.00 \mathrm{E}-16$ & $1.00 \mathrm{E}-16$ & 0.10 & 2.5 & 2700 & 1000 \\
\hline Fault -5900 to -5000 & FLTO1 & $6.00 \mathrm{E}-15$ & $6.00 \mathrm{E}-15$ & $3.00 \mathrm{E}-15$ & 0.10 & 2.5 & 2700 & 1000 \\
\hline Fault2 -5900 to -5000 & FLTO2 & $6.00 E-15$ & $6.00 \mathrm{E}-15$ & $3.00 \mathrm{E}-15$ & 0.10 & 2.5 & 2700 & 1000 \\
\hline Background -5000 to -4000 & BCKO3 & $5.00 \mathrm{E}-18$ & $5.00 \mathrm{E}-18$ & $1.00 \mathrm{E}-18$ & 0.03 & 2.5 & 2700 & 1000 \\
\hline 5 Ohm-m Contour -5000 to -4000 & INA02 & $5.00 \mathrm{E}-15$ & $5.00 E-15$ & $2.00 \mathrm{E}-15$ & 0.2 & 2.5 & 2700 & 1000 \\
\hline 3 Ohm-m Contour -5000 to -4000 & INBO2 & $5.00 E-15$ & $5.00 \mathrm{E}-15$ & $3.00 \mathrm{E}-15$ & 0.2 & 2.5 & 2700 & 1000 \\
\hline Buffer -5000 to -4000 & BUF02 & $5.00 E-15$ & $5.00 \mathrm{E}-15$ & $1.50 \mathrm{E}-15$ & 0.10 & 2.5 & 2700 & 1000 \\
\hline Buffer2 -5000 to -4000 & BFO02 & $1.00 \mathrm{E}-16$ & $1.00 \mathrm{E}-16$ & $1.00 \mathrm{E}-16$ & 0.05 & 2.5 & 2700 & 1000 \\
\hline Fault -5000 to -4000 & FLTO3 & $8.00 \mathrm{E}-15$ & $8.00 E-15$ & $5.00 \mathrm{E}-15$ & 0.10 & 2.5 & 2700 & 1000 \\
\hline Fault2 -5000 to -4000 & FLTO4 & $8.00 E-15$ & $8.00 \mathrm{E}-15$ & $5.00 \mathrm{E}-15$ & 0.10 & 2.5 & 2700 & 1000 \\
\hline Background -4000 to -3500 & BCKO4 & $1.00 E-17$ & $1.00 \mathrm{E}-17$ & $1.00 \mathrm{E}-17$ & 0.03 & 2.5 & 2700 & 1000 \\
\hline 3 Ohm-m Contour -4000 to -3500 & INA03 & $1.00 \mathrm{E}-14$ & $1.00 \mathrm{E}-14$ & $5.00 \mathrm{E}-15$ & 0.20 & 2.5 & 2700 & 1000 \\
\hline 5 Ohm-m Contour -4000 to -3500 & INBO3 & $6.00 \mathrm{E}-15$ & $6.00 \mathrm{E}-15$ & $3.00 \mathrm{E}-15$ & 0.20 & 2.5 & 2700 & 1000 \\
\hline Buffer -4000 to -3500 & BUF03 & $6.00 E-15$ & $6.00 \mathrm{E}-15$ & $2.00 \mathrm{E}-15$ & 0.10 & 2.5 & 2700 & 1000 \\
\hline Buffer2 -4000 to -3500 & BFO03 & $1.00 \mathrm{E}-16$ & $1.00 \mathrm{E}-16$ & $1.00 \mathrm{E}-16$ & 0.10 & 2.5 & 2700 & 1000 \\
\hline Fault -4000 to -3500 & FLTO5 & $7.00 E-15$ & 7.00E-15 & $5.00 \mathrm{E}-15$ & 0.10 & 2.5 & 2700 & 1000 \\
\hline Fault2 -4000 to -3500 & FLTO6 & $7.00 \mathrm{E}-15$ & $7.00 \mathrm{E}-15$ & $5.00 \mathrm{E}-15$ & 0.10 & 2.5 & 2700 & 1000 \\
\hline Background -3500 to -3000 & BCKO5 & $1.00 E-17$ & 1.00E-17 & $1.00 \mathrm{E}-17$ & 0.03 & 2.5 & 2700 & 1000 \\
\hline CFF -3500 to -3000 & INA04 & $1.00 E-14$ & $1.00 \mathrm{E}-14$ & $4.00 \mathrm{E}-14$ & 0.3 & 2.5 & 2700 & 1000 \\
\hline IFF -3500 to -3000 & INBO4 & $2.00 E-14$ & 2.00E-14 & $6.00 \mathrm{E}-14$ & 0.3 & 2.5 & 2700 & 1000 \\
\hline PFF -3500 to -3000 & InCO4 & $1.00 E-14$ & $1.00 \mathrm{E}-14$ & $2.00 \mathrm{E}-14$ & 0.3 & 2.5 & 2700 & 1000 \\
\hline $3 \mathrm{Ohm}-\mathrm{m}$ Contour -3500 to -3000 & BUF04 & 5.00E-15 & $5.00 \mathrm{E}-15$ & $5.00 \mathrm{E}-15$ & 0.20 & 2.5 & 2700 & 1000 \\
\hline $5 \mathrm{Ohm}-\mathrm{m}$ Contou -3500 to -3000 & BFO04 & $1.00 E-15$ & $1.00 \mathrm{E}-15$ & $1.00 \mathrm{E}-15$ & 0.10 & 2.5 & 2700 & 1000 \\
\hline Buffer -3500 to -3000 & BFO10 & $5.00 E-16$ & $5.00 \mathrm{E}-16$ & $5.00 \mathrm{E}-16$ & 0.10 & 2.5 & 2700 & 1000 \\
\hline Fault -3500 to -3000 & FLTO7 & $5.00 E-15$ & $5.00 E-15$ & $5.00 \mathrm{E}-15$ & 0.10 & 2.5 & 2700 & 1000 \\
\hline Fault2 -3500 to -3000 & FLT08 & $5.00 E-15$ & $5.00 \mathrm{E}-15$ & $5.00 \mathrm{E}-15$ & 0.10 & 2.5 & 2700 & 1000 \\
\hline Background - 3000 to -2000 & BCKO6 & $1.00 E-17$ & $1.00 E-17$ & $1.00 \mathrm{E}-17$ & 0.05 & 2.5 & 2700 & 1000 \\
\hline CFF -3000 to -2000 & INA05 & $5.00 E-14$ & $5.00 \mathrm{E}-14$ & $2.00 \mathrm{E}-13$ & 0.3 & 2.5 & 2700 & 1000 \\
\hline IFF -3000 to -2000 & INB05 & $5.00 \mathrm{E}-14$ & $5.00 \mathrm{E}-14$ & $3.00 \mathrm{E}-15$ & 0.3 & 2.5 & 2700 & 1000 \\
\hline PFF -3000 to -2000 & INCO5 & $5.00 E-14$ & $5.00 \mathrm{E}-14$ & $1.00 \mathrm{E}-13$ & 0.3 & 2.5 & 2700 & 1000 \\
\hline Fractured Zone -3000 to -2000 & FRZO1 & $1.00 \mathrm{E}-14$ & $1.00 \mathrm{E}-14$ & $5.00 \mathrm{E}-15$ & 0.25 & 2.5 & 2700 & 1000 \\
\hline Basement Greywacke -3000 to - 2000 & BSM01 & $5.00 \mathrm{E}-15$ & $5.00 \mathrm{E}-15$ & $1.00 \mathrm{E}-15$ & 0.15 & 2.5 & 2700 & 1000 \\
\hline Rotokawa Andesite -3000 to -2000 & RKA01 & $5.00 E-15$ & $5.00 \mathrm{E}-15$ & $1.00 \mathrm{E}-15$ & 0.15 & 2.5 & 2700 & 1000 \\
\hline Field Boundary - 3000 to -2000 & FLB01 & $1.00 \mathrm{E}-15$ & $1.00 \mathrm{E}-15$ & $8.00 \mathrm{E}-16$ & 0.10 & 2.5 & 2700 & 1000 \\
\hline Fault -3000 to -2000 & FLTO9 & $1.00 \mathrm{E}-16$ & $1.00 \mathrm{E}-16$ & $1.00 \mathrm{E}-14$ & 0.15 & 2.5 & 2700 & 1000 \\
\hline Fault2 -3000 to -2000 & FLT10 & $1.00 \mathrm{E}-16$ & $1.00 \mathrm{E}-16$ & $1.00 \mathrm{E}-14$ & 0.15 & 2.5 & 2700 & 1000 \\
\hline Background -2000 to -1500 & BCK07 & $1.00 \mathrm{E}-16$ & $1.00 E-16$ & $1.00 \mathrm{E}-16$ & 0.05 & 2.5 & 2700 & 1000 \\
\hline CFF -2000 to -1500 & INA06 & $5.00 E-14$ & $5.00 \mathrm{E}-14$ & $2.00 \mathrm{E}-13$ & 0.3 & 2.5 & 2700 & 1000 \\
\hline IFF - 2000 to -1500 & INB06 & $5.00 \mathrm{E}-14$ & $5.00 \mathrm{E}-14$ & $3.00 \mathrm{E}-15$ & 0.3 & 2.5 & 2700 & 1000 \\
\hline PFF -2000 to -1500 & INCO6 & $5.00 E-14$ & $5.00 \mathrm{E}-14$ & $1.00 \mathrm{E}-13$ & 0.3 & 2.5 & 2700 & 1000 \\
\hline Fractured Zone -2000 to -1500 & FRZO2 & $5.00 E-14$ & $5.00 \mathrm{E}-14$ & $1.00 \mathrm{E}-14$ & 0.25 & 2.5 & 2700 & 1000 \\
\hline Rotokawa Andesite - 2000 to -1500 & RKA02 & $2.00 \mathrm{E}-14$ & $2.00 \mathrm{E}-14$ & $5.00 \mathrm{E}-15$ & 0.15 & 2.5 & 2700 & 1000 \\
\hline Tahorakuri -2000 to -1500 & THK01 & $5.00 \mathrm{E}-15$ & $5.00 \mathrm{E}-15$ & $1.00 \mathrm{E}-16$ & 0.15 & 2.5 & 2700 & 1000 \\
\hline Outflow - 2000 to -1500 & OUT01 & $1.00 \mathrm{E}-15$ & $1.00 \mathrm{E}-15$ & $1.00 \mathrm{E}-15$ & 0.10 & 2.5 & 2700 & 1000 \\
\hline Field Boundary - 2000 to -1500 & FLB02 & 2.00E-15 & $2.00 \mathrm{E}-15$ & $1.00 \mathrm{E}-15$ & 0.10 & 2.5 & 2700 & 1000 \\
\hline Fault -2000 to -1500 & FLT11 & $1.00 \mathrm{E}-16$ & $1.00 \mathrm{E}-16$ & $1.00 \mathrm{E}-14$ & 0.15 & 2.5 & 2700 & 1000 \\
\hline Fault2 - 2000 to -1500 & FLT12 & $1.00 \mathrm{E}-16$ & $1.00 \mathrm{E}-16$ & $1.00 \mathrm{E}-14$ & 0.15 & 2.5 & 2700 & 1000 \\
\hline Background -1500 to -1000 & BCK08 & $1.00 \mathrm{E}-16$ & $1.00 \mathrm{E}-16$ & $1.00 \mathrm{E}-16$ & 0.05 & 2.5 & 2700 & 1000 \\
\hline CFF -1500 to -1000 & INA07 & $5.00 \mathrm{E}-14$ & $5.00 \mathrm{E}-14$ & $1.00 \mathrm{E}-13$ & 0.3 & 2.5 & 2700 & 1000 \\
\hline IFF -1500 to -1000 & INB07 & $5.00 E-14$ & $5.00 E-14$ & $1.50 \mathrm{E}-13$ & 0.3 & 2.5 & 2700 & 1000 \\
\hline PFF -1500 to -1000 & INCO7 & $5.00 E-14$ & $5.00 E-14$ & $5.00 \mathrm{E}-14$ & 0.3 & 2.5 & 2700 & 1000 \\
\hline Fractured Zone -1500 to -1000 & FRZO3 & $5.00 \mathrm{E}-14$ & $5.00 \mathrm{E}-14$ & $1.00 \mathrm{E}-14$ & 0.25 & 2.5 & 2700 & 1000 \\
\hline Rotokawa Andesite -1500 to -1000 & RKA03 & $2.00 \mathrm{E}-14$ & $2.00 \mathrm{E}-14$ & $1.00 \mathrm{E}-15$ & 0.15 & 2.5 & 2700 & 1000 \\
\hline Wairakei Ignimbrite - 1500 to -1000 & WIBO1 & $1.00 E-14$ & 1.00E-14 & $5.00 \mathrm{E}-15$ & 0.15 & 2.5 & 2700 & 1000 \\
\hline Outflow - 1500 to -1000 & OUT02 & $2.00 \mathrm{E}-15$ & $2.00 E-15$ & $5.00 \mathrm{E}-16$ & 0.15 & 2.5 & 2700 & 1000 \\
\hline Field Boundary - 1500 to -1000 & FLB03 & $1.00 \mathrm{E}-15$ & $1.00 \mathrm{E}-15$ & $1.00 \mathrm{E}-15$ & 0.10 & 2.5 & 2700 & 1000 \\
\hline Fault -1500 to -1000 & FLT13 & $1.00 E-16$ & $1.00 E-16$ & $1.00 \mathrm{E}-14$ & 0.15 & 2.5 & 2700 & 1000 \\
\hline Fault2 -1500 to -1000 & FLT14 & $1.00 \mathrm{E}-16$ & $1.00 E-16$ & $1.00 \mathrm{E}-14$ & 0.15 & 2.5 & 2700 & 1000 \\
\hline Background -1000 to -500 & BCKO9 & 1.00E-16 & $1.00 E-16$ & $1.00 \mathrm{E}-16$ & 0.05 & 2.5 & 2700 & 1000 \\
\hline Waiora -1000 to -500 & WRA01 & $6.00 \mathrm{E}-15$ & $6.00 \mathrm{E}-15$ & $3.00 \mathrm{E}-15$ & 0.15 & 2.5 & 2700 & 1000 \\
\hline Haparangi Rhyolite -1000 to -500 & HRY01 & $5.00 \mathrm{E}-15$ & $5.00 \mathrm{E}-15$ & $1.00 \mathrm{E}-15$ & 0.15 & 2.5 & 2700 & 1000 \\
\hline Haparangi Rhyolite2 -1000 to -500 & HRYO2 & $5.00 \mathrm{E}-15$ & $5.00 \mathrm{E}-15$ & $1.00 \mathrm{E}-15$ & 0.15 & 2.5 & 2700 & 1000 \\
\hline Fractured Zone -1000 to -500 & FRZO4 & $1.00 E-14$ & $1.00 \mathrm{E}-14$ & $3.00 \mathrm{E}-15$ & 0.25 & 2.5 & 2700 & 1000 \\
\hline Outflow -1000 to -500 & OUT03 & $2.00 \mathrm{E}-15$ & $2.00 \mathrm{E}-15$ & $5.00 \mathrm{E}-16$ & 0.15 & 2.5 & 2700 & 1000 \\
\hline Field Boundary -1000 to -500 & FLBO4 & $1.00 \mathrm{E}-15$ & $1.00 \mathrm{E}-15$ & $5.00 \mathrm{E}-16$ & 0.10 & 2.5 & 2700 & 1000 \\
\hline Fault -1000 to -500 & FLT15 & $1.00 E-16$ & $1.00 \mathrm{E}-16$ & $5.00 \mathrm{E}-14$ & 0.15 & 2.5 & 2700 & 1000 \\
\hline Fault2 -1000 to -500 & FLT16 & $1.00 \mathrm{E}-16$ & $1.00 \mathrm{E}-16$ & $5.00 \mathrm{E}-14$ & 0.15 & 2.5 & 2700 & 1000 \\
\hline Background -500 to - 100 & BCK10 & $5.00 E-16$ & $5.00 \mathrm{E}-16$ & $1.00 \mathrm{E}-16$ & 0.1 & 2.5 & 2700 & 1000 \\
\hline Waiora -500 to -100 & WRA02 & $1.00 \mathrm{E}-15$ & $1.00 \mathrm{E}-15$ & $1.00 \mathrm{E}-17$ & 0.2 & 2.5 & 2700 & 1000 \\
\hline Haparangi Rhyolite -500 to -100 & HRYO3 & $1.00 E-15$ & $1.00 \mathrm{E}-15$ & $1.00 \mathrm{E}-17$ & 0.2 & 2.5 & 2700 & 1000 \\
\hline Haparangi Rhyolite2 -500 to - 100 & HRYO4 & $1.00 \mathrm{E}-15$ & $1.00 \mathrm{E}-15$ & $2.00 \mathrm{E}-15$ & 0.2 & 2.5 & 2700 & 1000 \\
\hline Hole in Cap - 500 to -100 & LEK01 & $1.00 E-15$ & $1.00 E-15$ & $2.00 \mathrm{E}-15$ & 0.2 & 2.5 & 2700 & 1000 \\
\hline Fault -500 to -100 & FLT17 & $5.00 \mathrm{E}-16$ & $5.00 \mathrm{E}-16$ & $5.00 \mathrm{E}-14$ & 0.15 & 2.5 & 2700 & 1000 \\
\hline Fault2-500 to -100 & FLT18 & $5.00 E-16$ & $5.00 E-16$ & $5.00 E-14$ & 0.15 & 2.5 & 2700 & 1000 \\
\hline Background -100 to 0 & BCK11 & $1.00 \mathrm{E}-16$ & $1.00 \mathrm{E}-16$ & $1.00 \mathrm{E}-16$ & 0.1 & 2.5 & 2700 & 1000 \\
\hline Huka Falls -100 to 0 & HKF01 & $1.00 \mathrm{E}-17$ & $1.00 \mathrm{E}-17$ & $1.00 \mathrm{E}-18$ & 0.1 & 2.5 & 2700 & 1000 \\
\hline Huka Falls2 -100 to 0 & HKFO2 & $1.00 E-17$ & $1.00 E-17$ & $1.00 \mathrm{E}-18$ & 0.1 & 2.5 & 2700 & 1000 \\
\hline Hole in Cap - 100 to 0 & LEK02 & $1.00 \mathrm{E}-15$ & $1.00 \mathrm{E}-15$ & $1.00 \mathrm{E}-15$ & 0.2 & 2.5 & 2700 & 1000 \\
\hline Hole in Cap2 -100 to 0 & LEKO3 & $1.00 \mathrm{E}-15$ & $1.00 \mathrm{E}-15$ & $1.00 \mathrm{E}-15$ & 0.2 & 2.5 & 2700 & 1000 \\
\hline Fault -100 to 0 & FLT19 & $5.00 E-16$ & $5.00 \mathrm{E}-16$ & $2.00 E-14$ & 0.15 & 2.5 & 2700 & 1000 \\
\hline Fault2 -100 to 0 & FLT2O & $5.00 E-16$ & $5.00 \mathrm{E}-16$ & $2.00 \mathrm{E}-14$ & 0.15 & 2.5 & 2700 & 1000 \\
\hline \begin{tabular}{|l|} 
Background 0 to surface \\
\end{tabular} & BCK12 & $5.00 \mathrm{E}-13$ & $5.00 \mathrm{E}-13$ & $1.00 \mathrm{E}-13$ & 0.2 & 2.5 & 2700 & 1000 \\
\hline
\end{tabular}




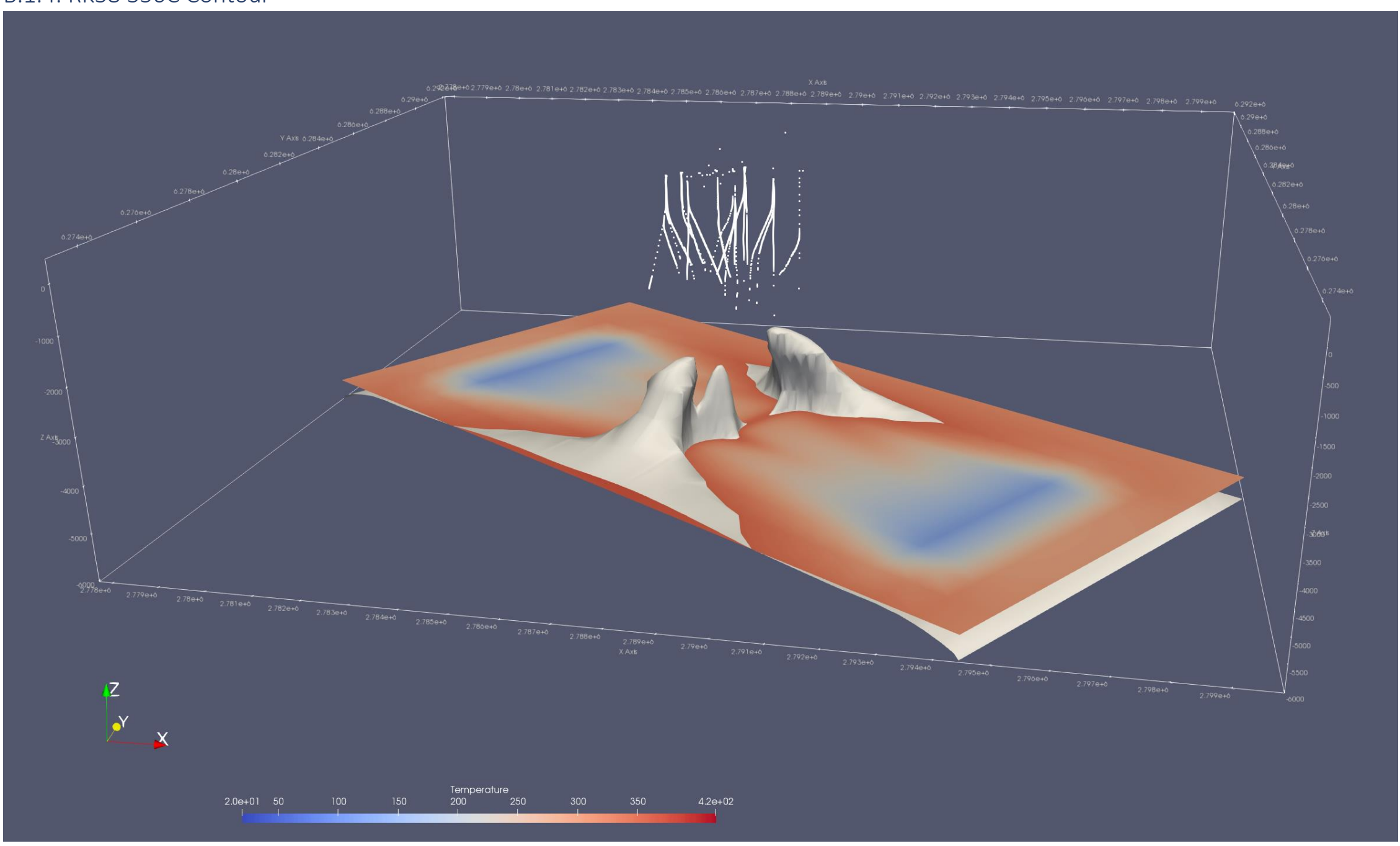

A Tempertaure slice shown at $-5500 \mathrm{mRSL}$ and well tracks are shown in with the countour. 


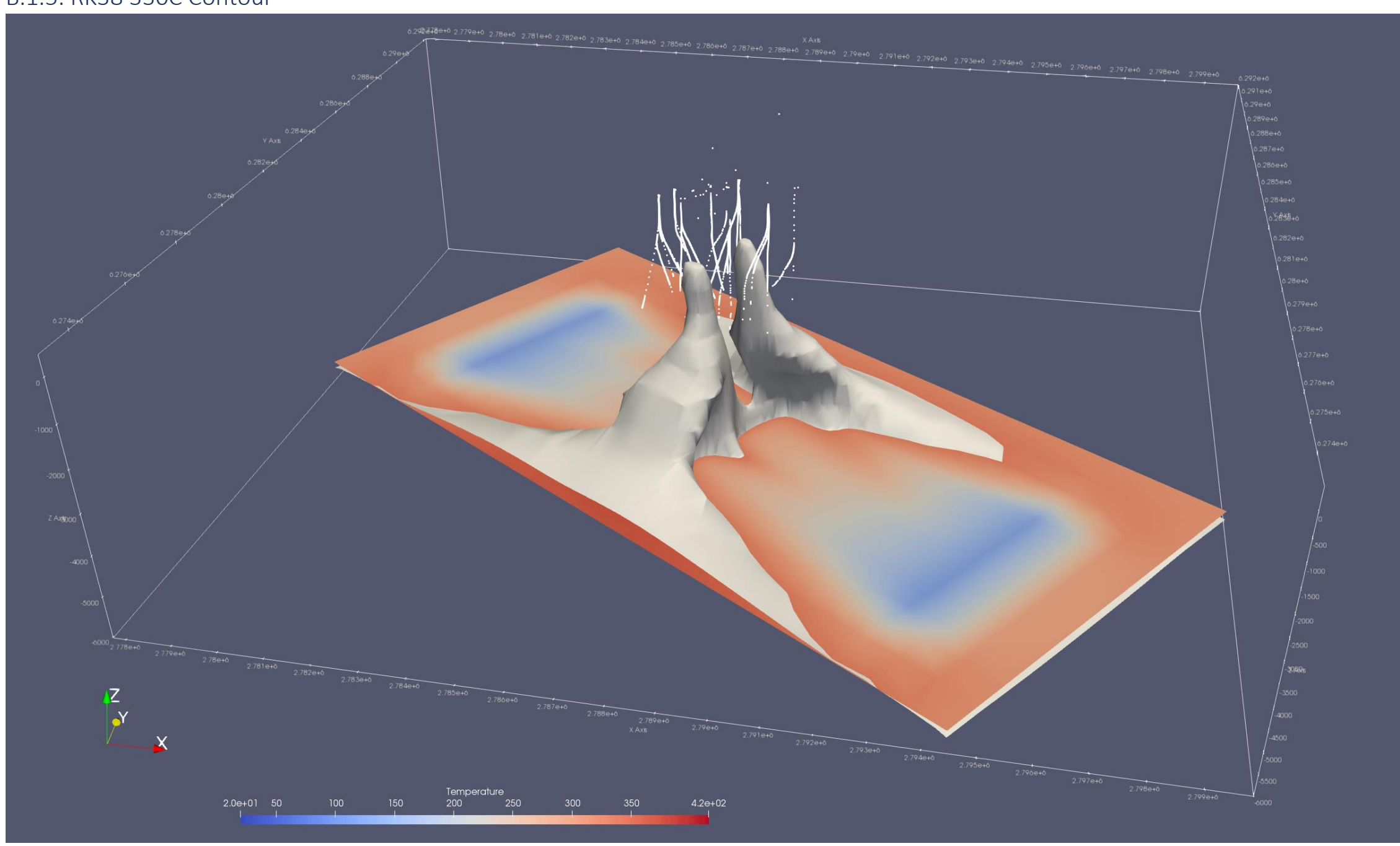

A tempertaure slice shown at $-5500 \mathrm{mRSL}$ and well tracks are shown in with the countour. 


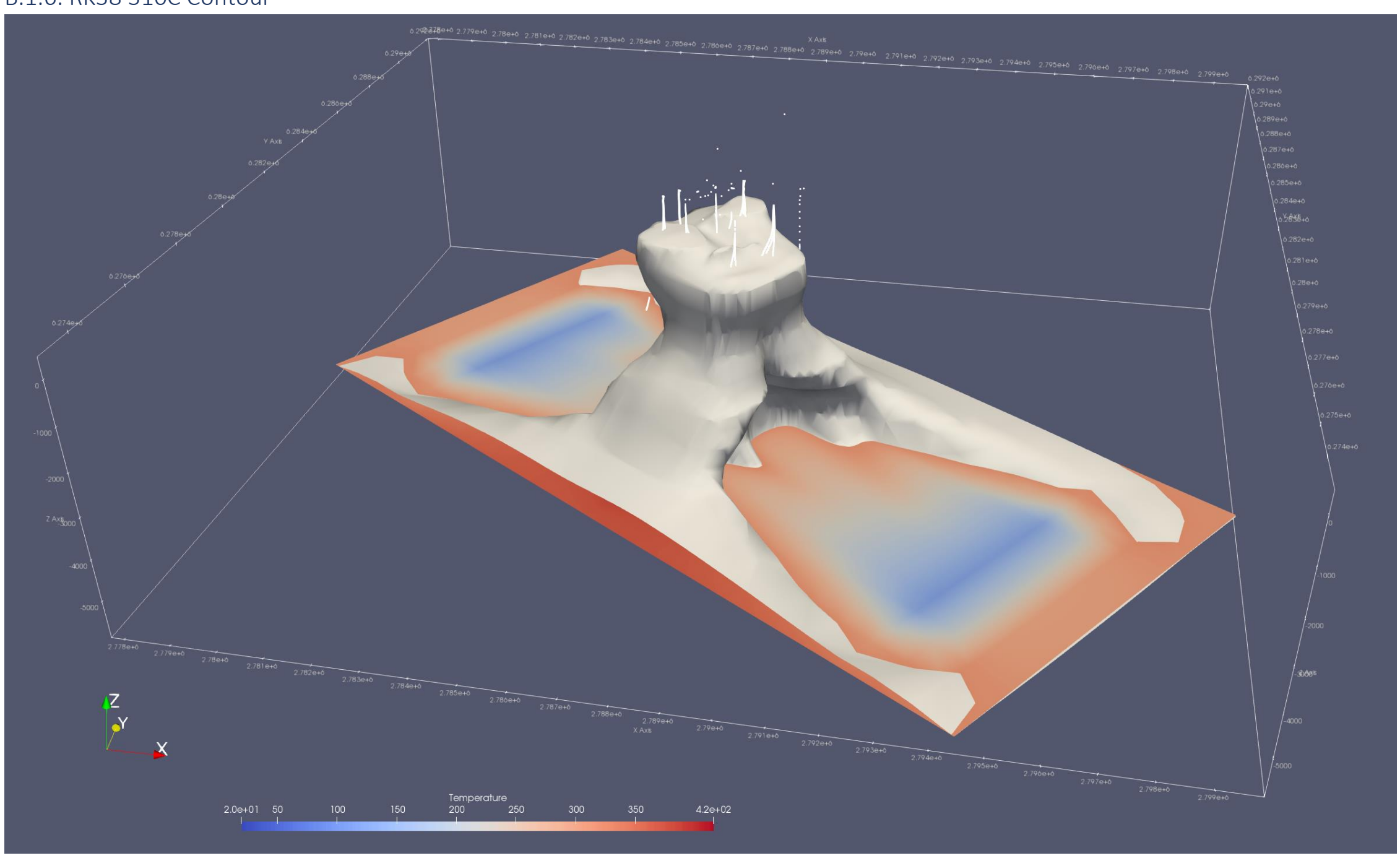

A tempertaure slice shown at $-5500 \mathrm{mRSL}$ and well tracks are shown in with the countour. 


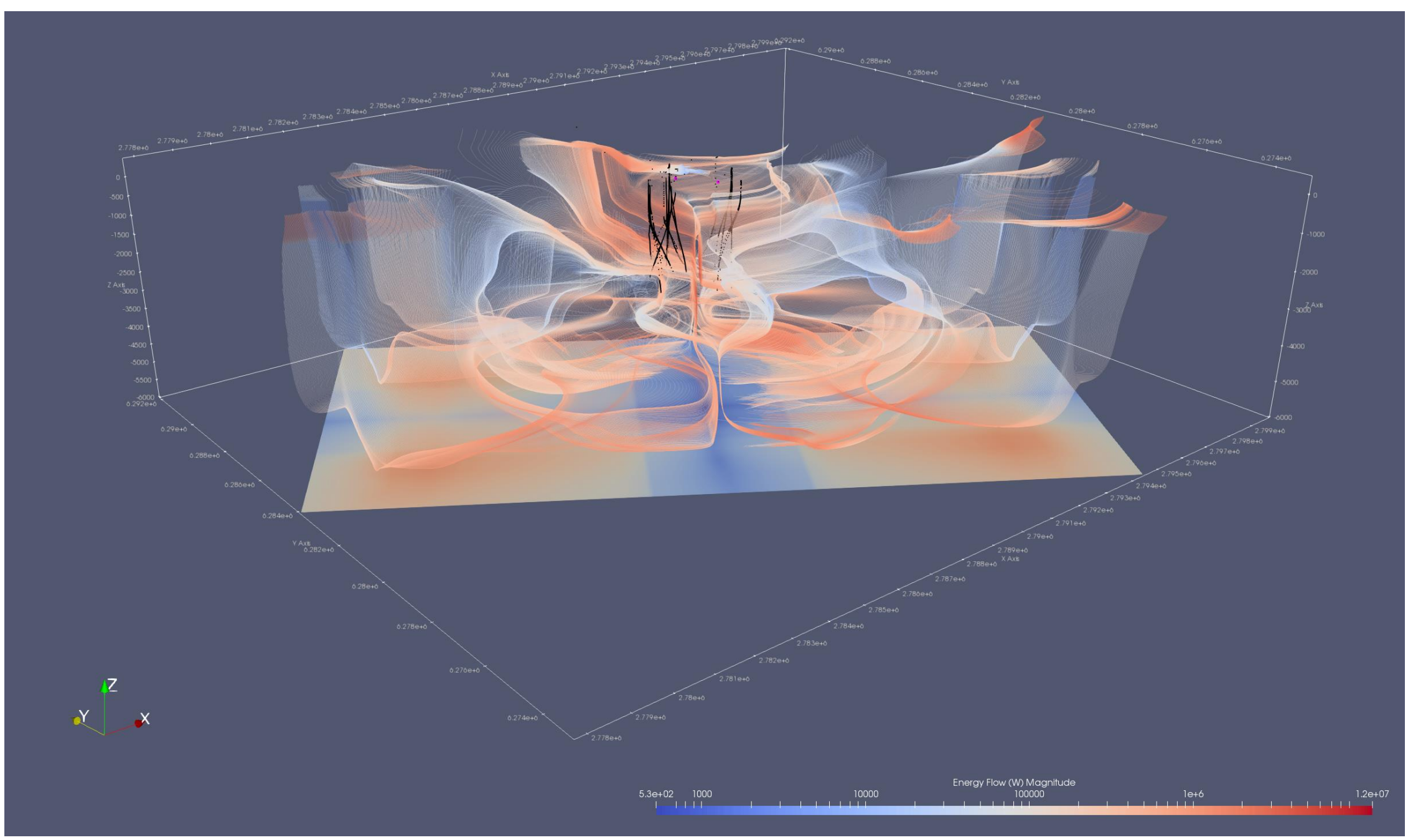

Magnatude of energy flow. Slice of energy flow at -5999 mRSL scale is logarithmic. 
B.1.8. RK38 Streamlines-Vertical fluid flow $(\mathrm{kg} / \mathrm{s})$

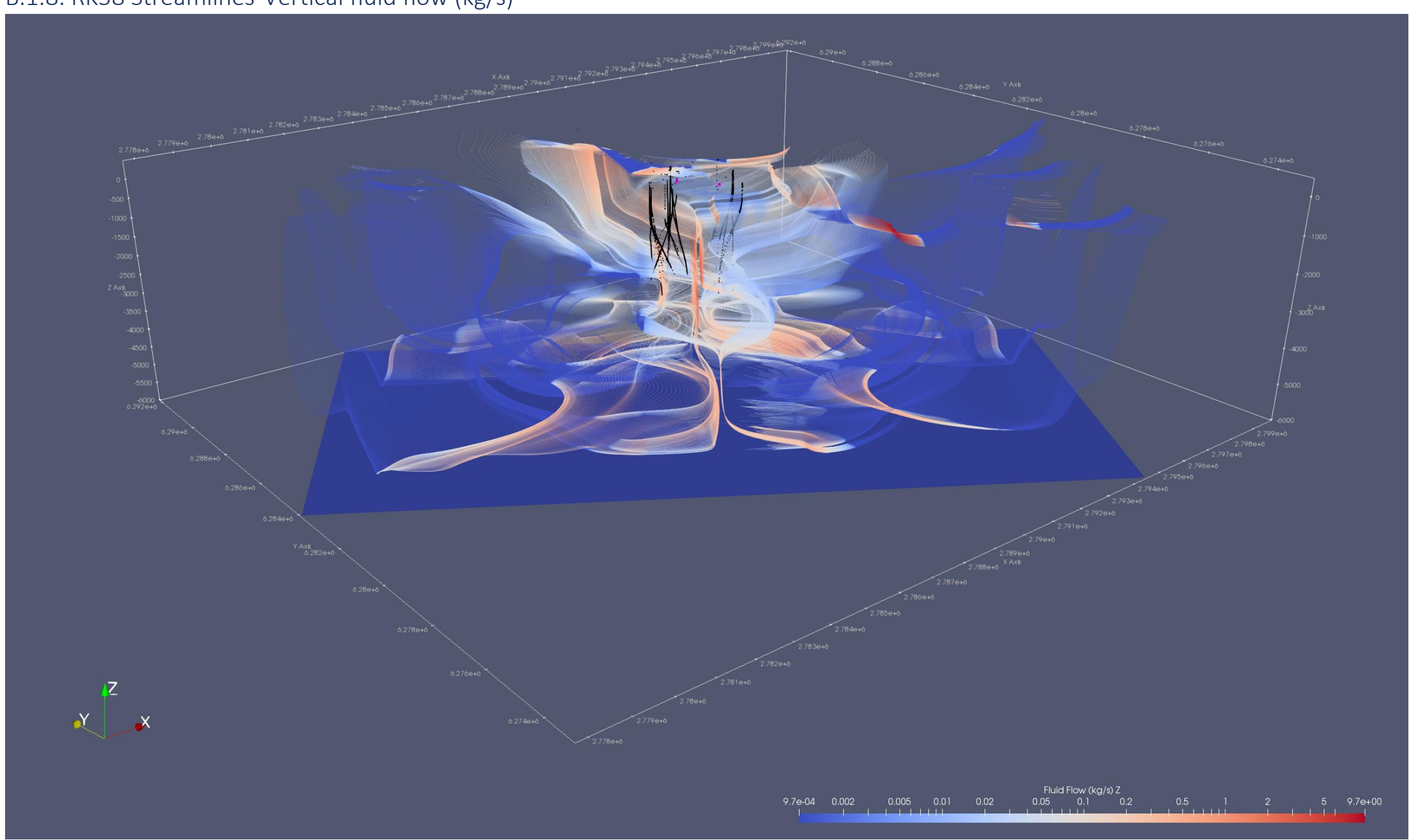


B.2. Fault Process Model

B.2.1. Fault Process Model Layers

\begin{tabular}{|c|c|c|}
\hline Layer & $\begin{array}{l}\text { Top Elevation } \\
\text { (mRSL) }\end{array}$ & $\begin{array}{l}\text { Thickness } \\
\text { (m) }\end{array}$ \\
\hline 1 & 300 & 300 \\
\hline 2 & 0 & 500 \\
\hline 3 & -500 & 500 \\
\hline 4 & -1000 & 500 \\
\hline 5 & -1500 & 500 \\
\hline 6 & -2000 & 500 \\
\hline 7 & -2500 & 500 \\
\hline 8 & -3000 & 500 \\
\hline 9 & -3500 & 500 \\
\hline 10 & -4000 & 500 \\
\hline 11 & -4500 & 500 \\
\hline 12 & -5000 & 500 \\
\hline 13 & -5500 & 500 \\
\hline 14 & -6000 & 500 \\
\hline 15 & -6500 & 500 \\
\hline 16 & -7000 & 500 \\
\hline 17 & -7500 & 100 \\
\hline 18 & -7600 & 100 \\
\hline 19 & -7700 & 100 \\
\hline 20 & -7800 & 100 \\
\hline 21 & -7900 & 50 \\
\hline 22 & -7950 & 50 \\
\hline Base & -8000 & - \\
\hline
\end{tabular}


B.2.2. Variable Rainfall Infiltration

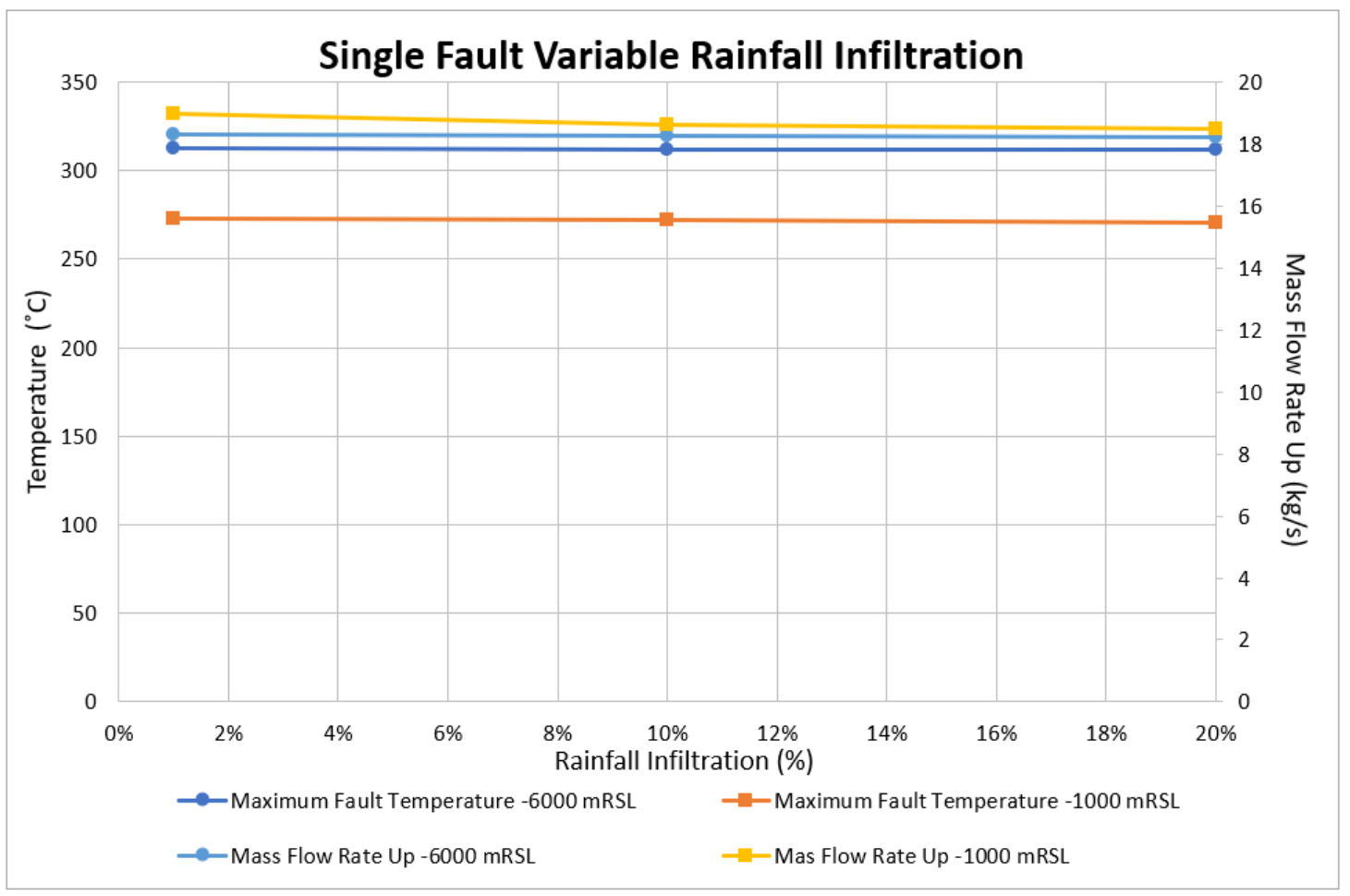

B.2.3. Variable Specific Heat

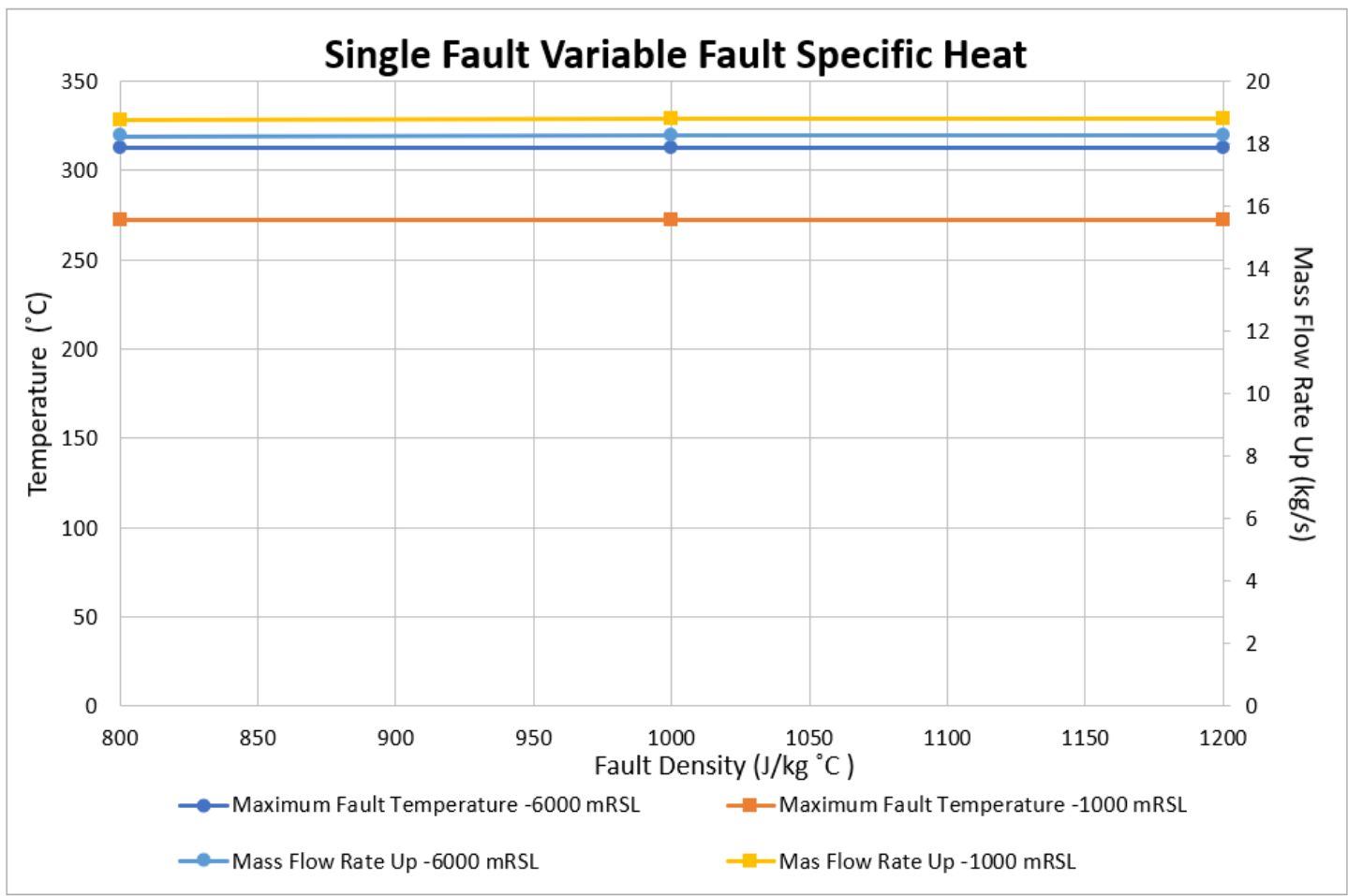


B.2.4. Variable Fault Conductivity

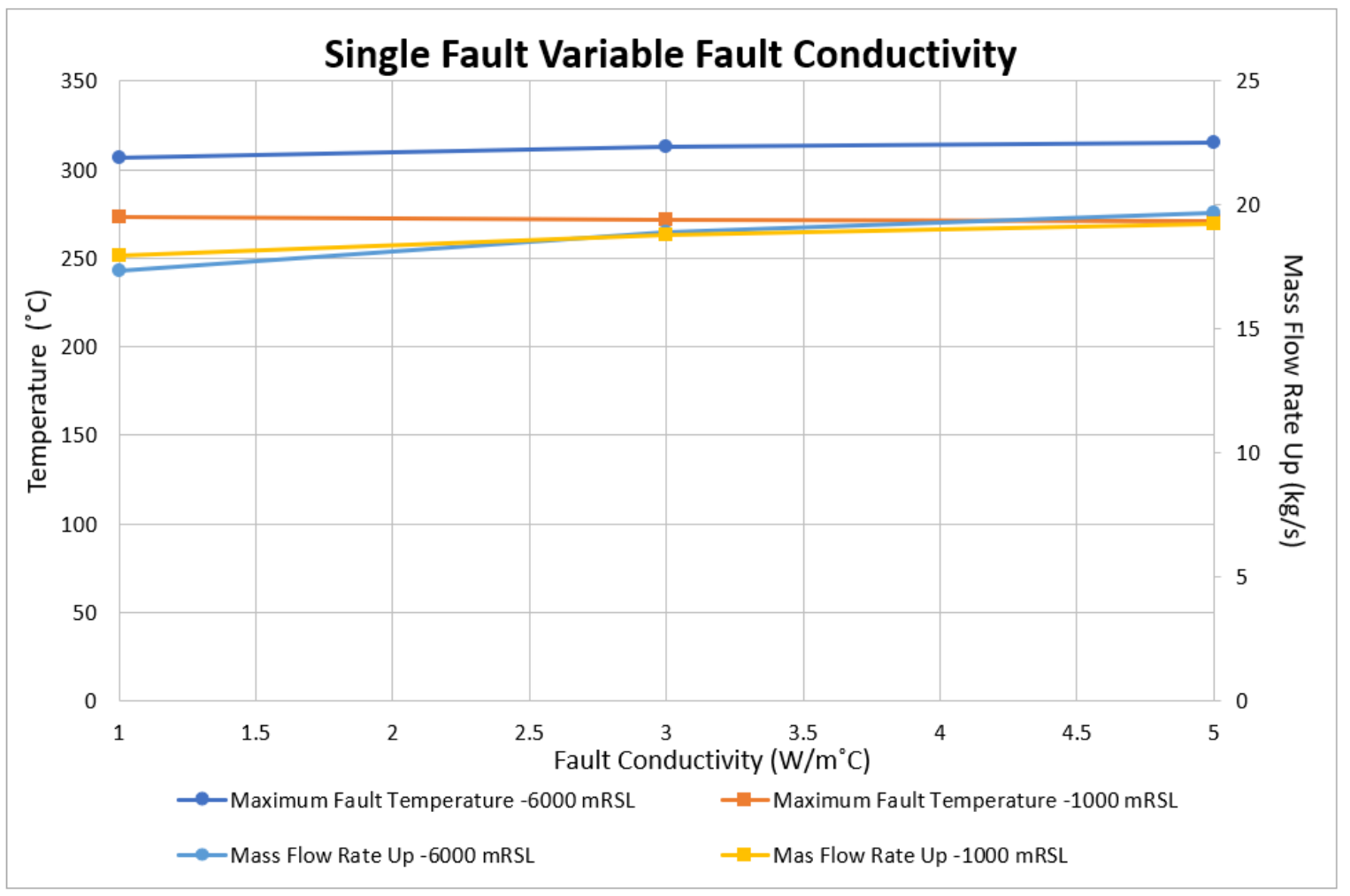

B.2.5. Variable Fault Porosity

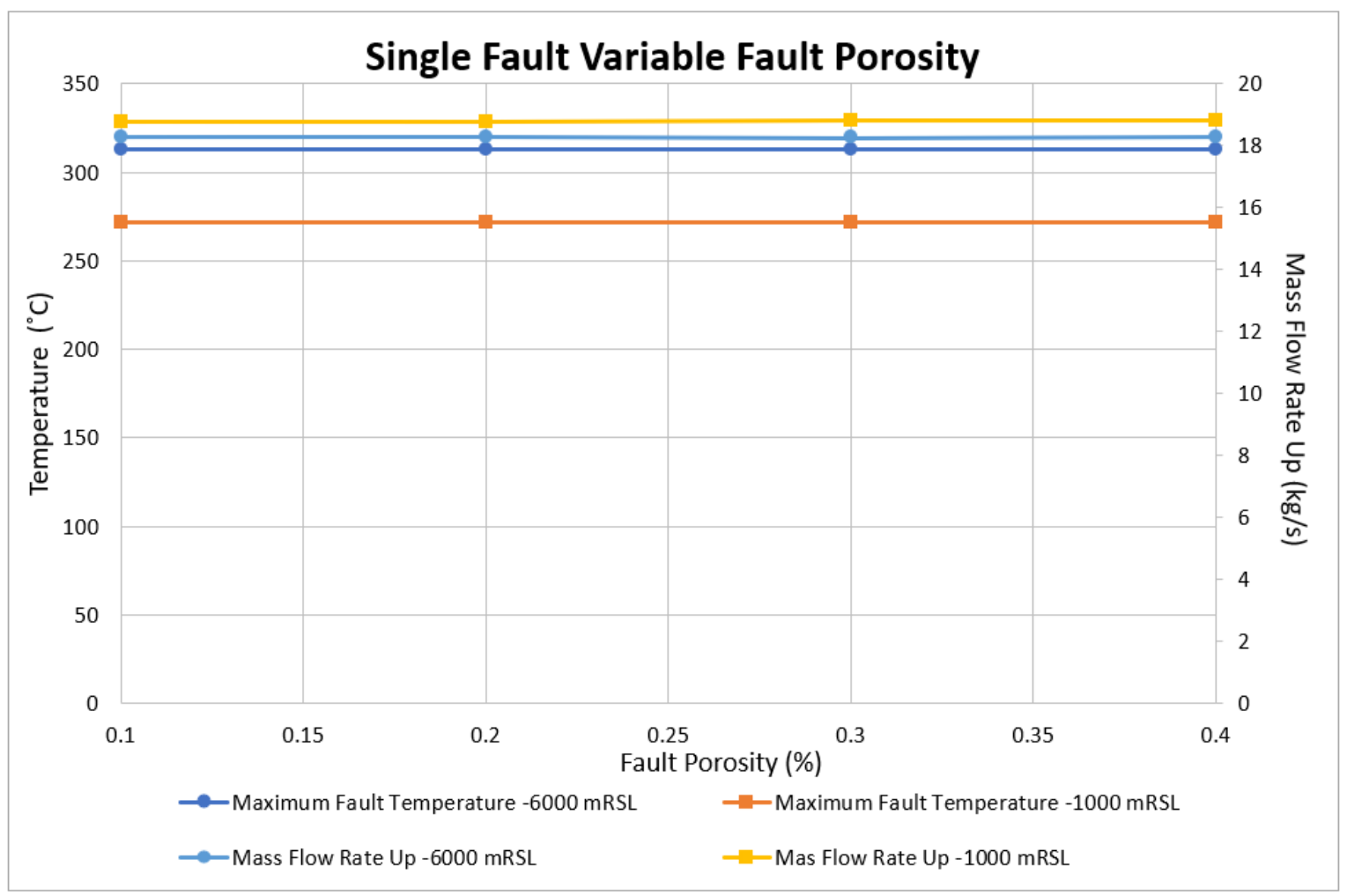


B.2.6. Variable Fault Density

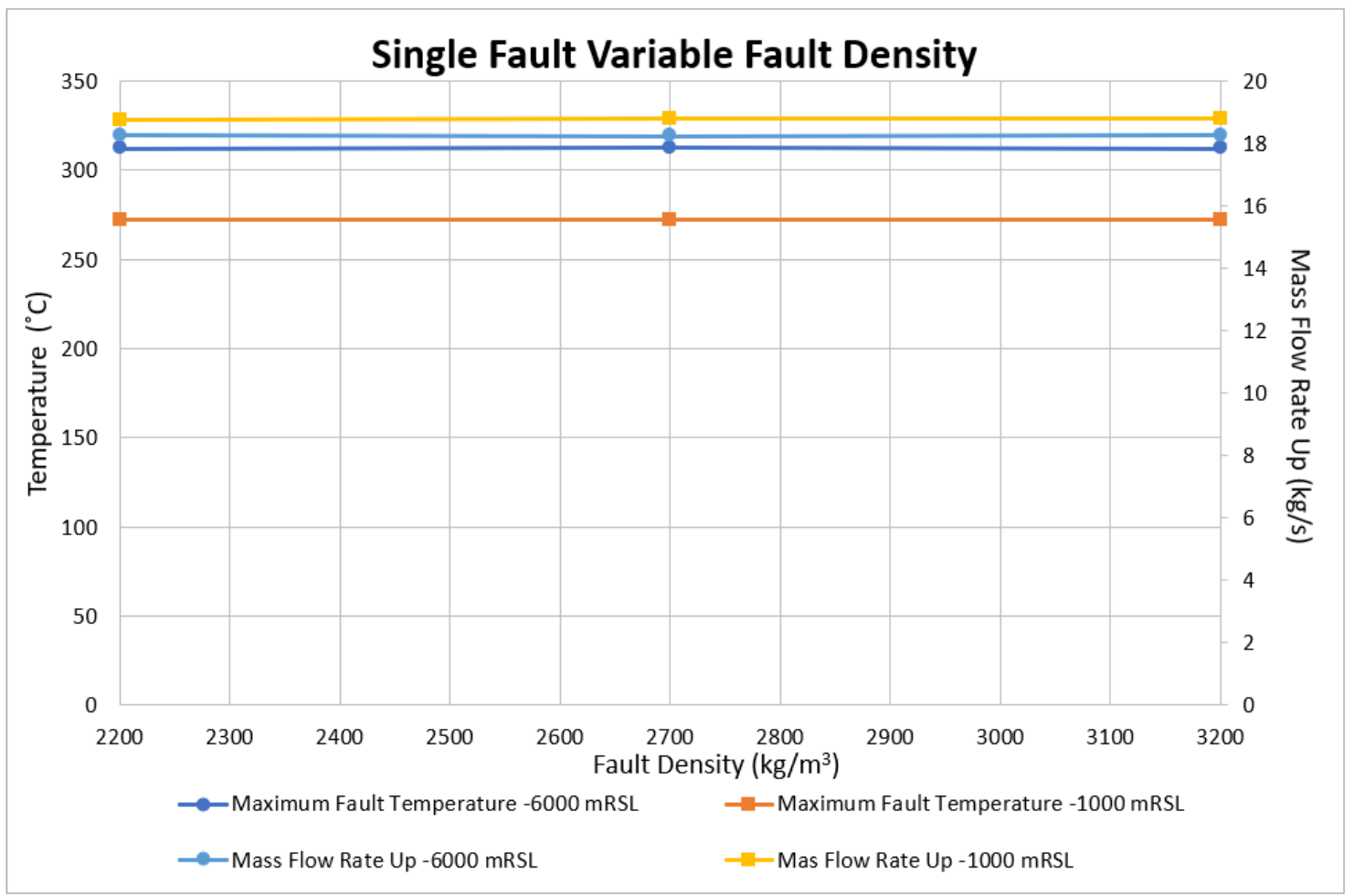




\section{Appendix C}

\section{C.1. Additional literature figures}

\section{C.1.1. TVZ Geothermal Field Fault and Fracture Trends}

\section{Geothermal Fields}

Wairakei Rotokawa Broadlands- Orakei-Korako/ Waimangu
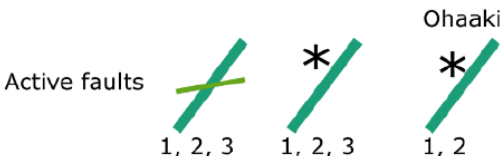

$$
\text { Te Kopia }
$$

Non active

$$
\begin{array}{lll}
1,2 & 1,2,3, & 1,2,3 \\
15,18 & 15,18
\end{array}
$$

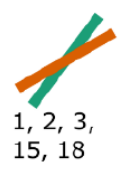

faults

Geophysics

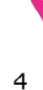

Image log
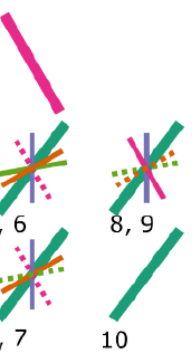

3D modelling

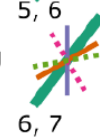

10

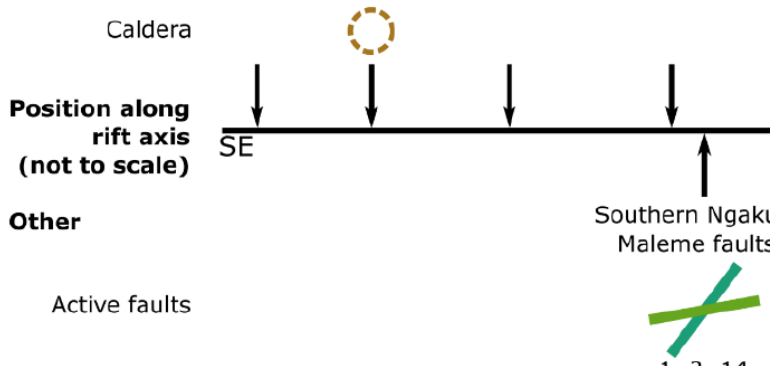

$1,2,14$

Non active faults

Geophysics

Caldera

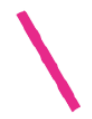

\section{6}

Rotorua Kawerau

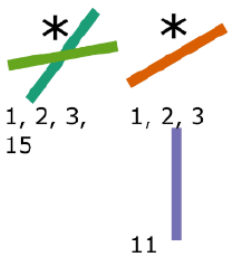

16

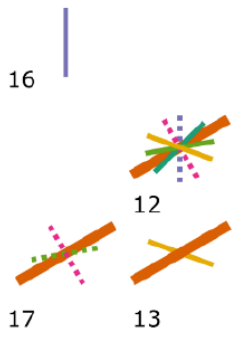

17

0

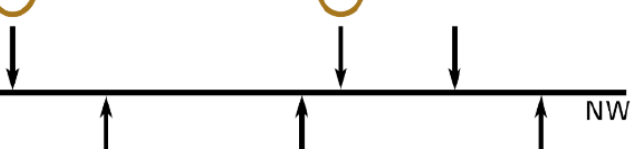

Te Kanakana Manawahe_Braemar

Tumuni Fault
Te Kanakands Road faults
Fault
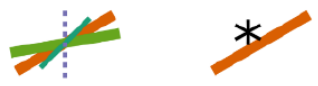

$1,2,14,21$

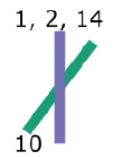

1,2

Faults

15

10

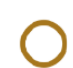

Fault/fracture trends

Rift trends:

N60E

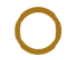

Position re. caldera

$\bigcirc$ in caldera

$\longrightarrow$ Secondary

(j) near caldera edge 
C.1.2. Rotokawa Microseicmic Location

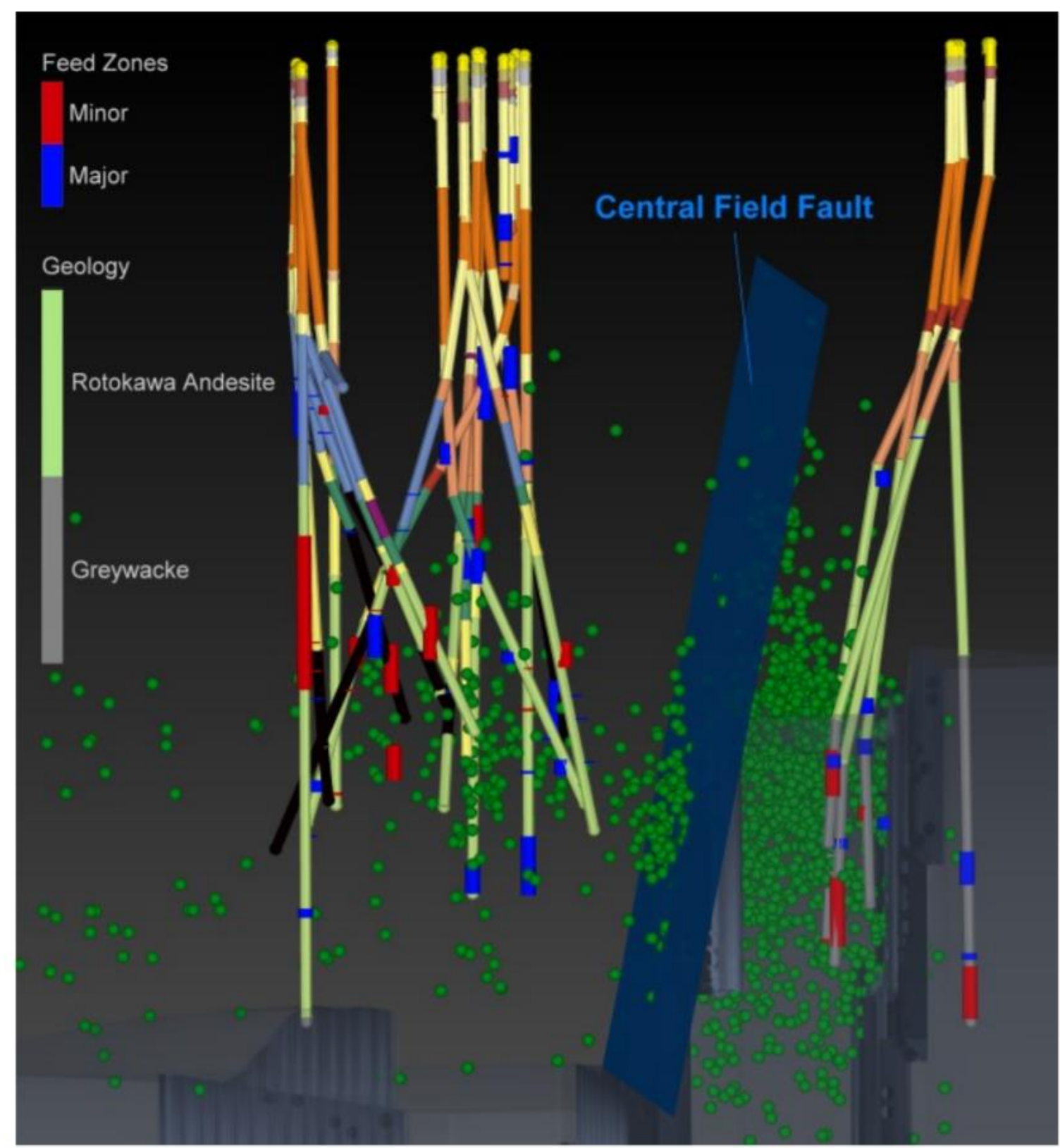

MEQ's from July, 2008 to December, 2012, the Central Field Fault and greywacke. Vertical displacement in the greywacke across the fault is $\sim 500 \mathrm{~m}$ (Sewell et al. 2015). 


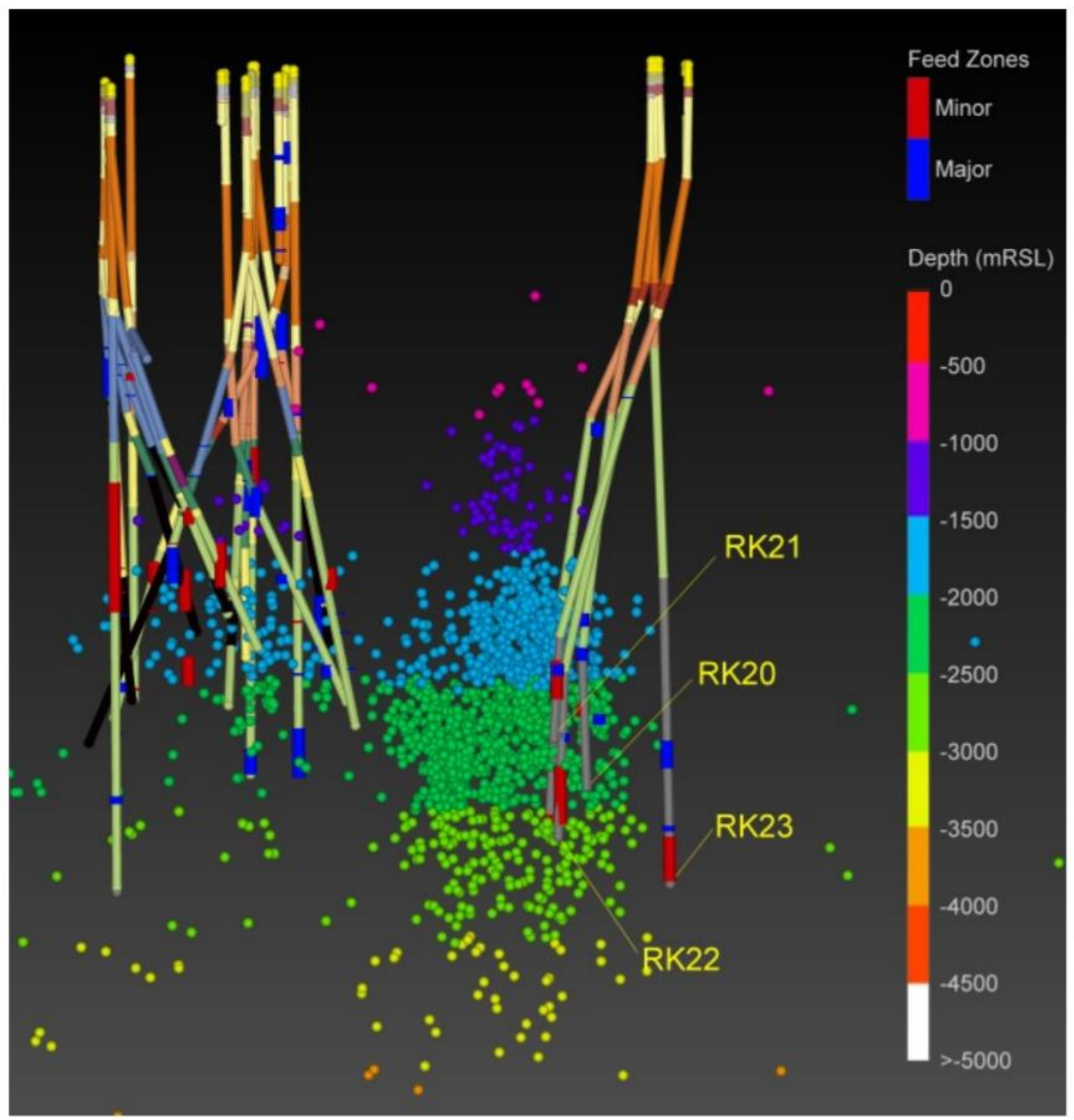

MEQ with depth in relation to injection feed zones (blue and red bars on well tracks). The majority of MEQ activity has been at the same depths as injection feed zones (-1500m to $-3000 \mathrm{~m}$ elevation). Relatively few events have occurred below the injection feeds and from this, vertical permeability in the injection area is inferred to be relatively low (Sewell et al. 2015). 


\section{C.1.3. Rock Properties of TVZ TOUGH2 Modeling}

Permeability ranges used in Model IV for the interior region.

\begin{tabular}{|c|c|c|c|c|c|}
\hline \multirow[t]{2}{*}{ Level } & \multirow[t]{2}{*}{ Geological unit } & \multicolumn{2}{|c|}{$\begin{array}{l}\text { Horizontal k } \\
(\mathrm{mD})\end{array}$} & \multicolumn{2}{|c|}{$\begin{array}{l}\text { Vertical k } \\
(\mathrm{mD})\end{array}$} \\
\hline & & Min & $\operatorname{Max}$ & Min & $\operatorname{Max}$ \\
\hline \multirow[t]{3}{*}{ Surface } & Faults & 17.52 & 4.97 & 17.52 & 4.97 \\
\hline & Volcanic centres & 0.23 & 6.60 & 0.47 & 6.74 \\
\hline & Rest of interior & 4.18 & 7.18 & 3.06 & 7.00 \\
\hline \multirow[t]{3}{*}{ Mid } & Faults & 17.52 & 1.97 & 17.52 & 1.97 \\
\hline & Volcanic centres & 0.13 & 17.52 & 0.04 & 7.97 \\
\hline & Rest of interior & 4.38 & 7.18 & 0.05 & 5.00 \\
\hline \multirow[t]{3}{*}{ Deep } & Faults & 27.55 & 2.71 & 27.55 & 2.71 \\
\hline & Beneath the volcanic centres & 1.83 & 6.17 & 2.00 & 4.67 \\
\hline & Rest of interior & 0.30 & 8.04 & 0.10 & 2.34 \\
\hline
\end{tabular}

Initial rock properties used in the model.

\begin{tabular}{lllll}
\hline Unit & $\begin{array}{l}\text { Density } \\
\left(\mathrm{kg} / \mathrm{m}^{3}\right)\end{array}$ & Porosity & $\begin{array}{l}\text { Thermal conductivity } \\
(\mathrm{W} /(\mathrm{m} \mathrm{K}))\end{array}$ & $\begin{array}{l}\text { Specific heat } \\
(\mathrm{J} /(\mathrm{kg} \mathrm{K}))\end{array}$ \\
\hline Shallow infill & 2200 & 0.1 & 3.0 & 1000 \\
Deep infill & 2650 & 0.01 & 3.0 & 1000 \\
Exterior & 2650 & 0.01 & 3.0 & 1000 \\
Faults & 2200 & 0.1 & 3.0 & 1000 \\
\hline
\end{tabular}

Initial rock properties and permeabilities used in model IV of, Kaya et al. (2014) 
C.1.4. Helium and carbon isotopes in gas, and zoning in non-reactive gases ( $A r, N)$

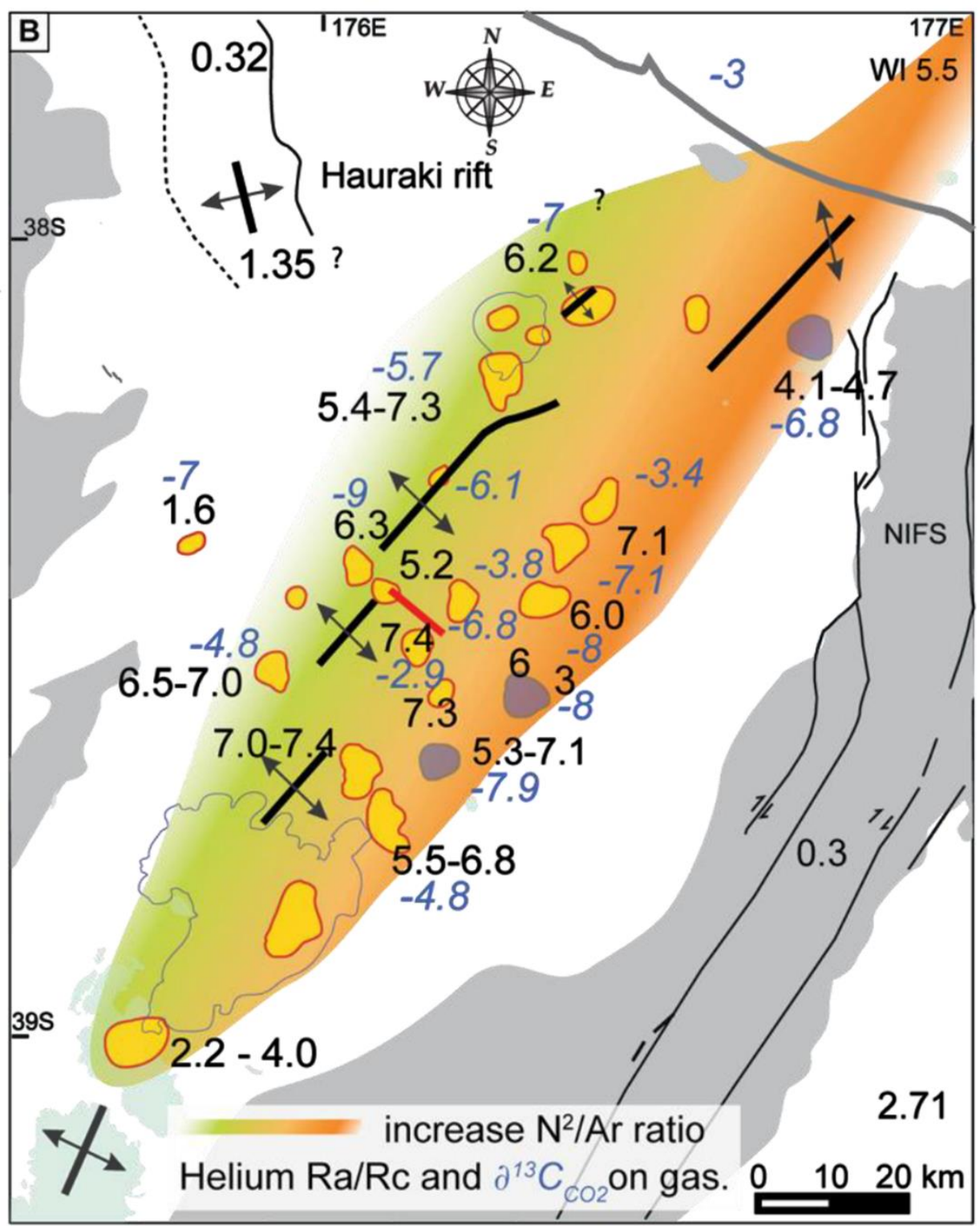

Helium and carbon isotopes in gas, and zoning in non-reactive gases ( $\mathrm{Ar}, \mathrm{N})$ (Chamberfort et al. 2017). 


\section{C.1.5. Geologic structure and residual gravity map}
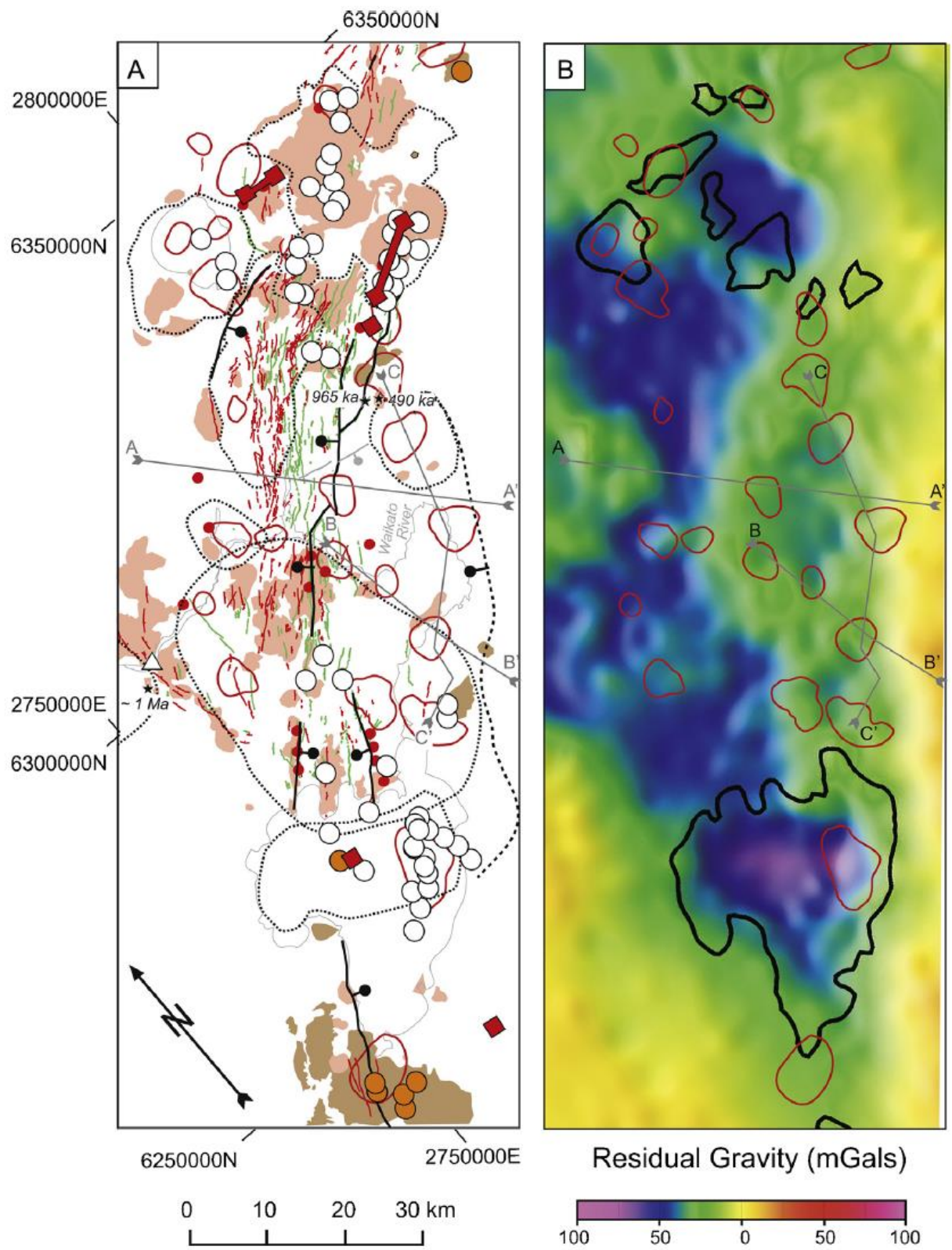

Geologic structure and residual gravity map from Wilson et. al 2016 primarily to show the cross section of the deep conceptual model.

\section{References}

\section{There are no sources in the current document.}

Albertsson, A., J. O. Bjarnason, T. Gunnarsson, C. Ballzus, and K. Ingason (2003), The Iceland Deep Drilling Project: Fluid handling evaluation and utilization, in Proceedings of the International Geothermal Conference IGC-2003 Reykjavik, September 2003, Session 623-30. 
Bowyer, D., Holt, R., 2010. Case study: Development of a numerical model by amulti-disciplinary approach, Rotokawa Geothermal Field, New Zealand. In:Proceedings World Geothermal Congress 2010, Bali, Indonesia.

Bibby, H.M., Caldwell, T.G., Davey, F.J., Webb, T.H., 1995. Geophysical evidence on the structure of the Taupo Volcanic Zone and its hydrothermal circulation. J. Volcanol. Geothermal Res. 68, 29-58.

Bertrand, Edward \& Caldwell, T.G. \& Bannister, Stephen \& Soengkono, Supri \& Bennie, Stewart \& Hill, Graham \& Heise, Wiebke. (2015). Using array MT data to image the crustal resistivity structure of the southeastern Taupo Volcanic Zone, New Zealand. Journal of Volcanology and Geothermal Research. 305.

10.1016/j.jvolgeores.2015.09.020.

Bertrand, E., Caldwell, T., Hill, G., Wallin, E., Bennie, S., Cozens, N., Onacha, S., G Ryan, Walter, C., Zaino, A., Wameyo, P.: Magnetotelluric imaging of upper-crustal convection plumes beneath the Taupo Volcanic Zone, New Zealand. Geophysical Research Letters Volume 39, Issue 2. (2012).

Bürgmann, R., Dresen, G., 2008. Rheology of the lower crust and upper mantle: evidence from rock mechanics, geodesy, and field observations. Annu. Rev. Earth Planet. Sci. 36, 531-567.

Chambefort, I., Lewis, B., Wilson, C.J.N., Rae, A.J., Coutts, C., Bignall, G. and Ireland, T.R.: Stratigraphy and structure of the Ngatamariki geothermal system from new zircon U-Pb geochronology: implications for Taupo Volcanic Zone evolution. J. Volcanol. Geotherm. Res., 274, 51-70 (2014).

Chen, W.P., Molnar, P., 1983. Focal depths of intracontinental and intraplate earthquakes and their implications for the thermal and mechanical properties of the lithosphere. J. Geophys. Res. 88, 4183-4214.

C. J. Bryan , S. Sherburn , H. M. Bibby , S. C. Bannister \& A. W. Hurst (1999) Shallow seismicity of the central Taupo Volcanic Zone, New Zealand: Its distribution and nature, New Zealand Journal of Geology and Geophysics, 42:4, 533-542, DOI: 10.1080/00288306.1999.9514859

Clearwater, J., Hernandez, D., Sewell, S., Addison, S.: Model-based decision making to manage production in the western compartment at Rotokawa. Proceedings 38th New Zealand Geothermal Workshop. Auckland, New Zealand, 23-25 November 2016, paper 25. (2016).

Davidson, Jonathan \& Siratovich, Paul \& Wallis, Irene \& Gravley, Darren \& McNamara, David. (2012). Quantifying the stress distribution at the Rotokawa Geothermal Field, New Zealand. 10.13140/RG.2.1.3565.2088.

Edbrooke, S.W., Heron, D.W., Forsyth, P.J. \& Jongens, R.: Geological Map of New Zealand, 1:1,000,000. GNS Science Geological Map 2. 2 sheets. Lower Hutt, New Zealand. GNS Science. (2015).

Fournier, R.O., 1999. Hydrothermal processes related to movement of fluid from plastic into brittle rock in the magmatic-epithermal environment. Bull. Soc. Econ. Geol. 94, 1193.1211.

Giggenbach, W.F.: Variations in the chemical and isotopic compositions of fluids discharged from the Taupo Volcanic Zone, New Zealand. J. Volcanol. Geotherm. Res., 68, 89-116 (1995).

GNS Active Fault Database, 2017. http://maps.gns.cri.nz/website/af/

Grant, Malcolm A., and Paul F. Bixley. Geothermal Reservoir Engineering. Academic Press, 2016.

Hanano, M., 2004, Contribution of fractures to formation and production of geothermal resources: Renewable and Sustainable Energy Reviews, v. 8, no. 3, p. 223-236.

Hayba, D. O. \& Ingebritsen, S. E. Multiphase groundwater flow near cooling plutons. J. Geophys. Res. 102, 12235_12252 (1997). 
Heise, W., Caldwell, T.G., Bibby, H.M., Bennie S.L.: Three-dimensional electrical resistivity image of magma beneath an active continental rift, Taupo Volcanic Zone, New Zealand. Geophys Res Lett, 37, L10301, doi:10.1029/2010GL043110. (2010).

Hernandez, D., Clearwater, J., Burnell, J., Franz, P., Azwar, L., Marsh, A., 2015. Update on the modeling of the Rotokawa Geothermal System: 2010-2014. In: Proceedings World Geothermal Congress 2015, Melbourne, Australia, 19-25 April, 2015.

Hernandez, Dario \& Addison, Simon \& Sewell, Steven \& Azwar, Lutfhie \& Barnes, Mike. (2015). Rotokawa: Reservoir Response of 172MW Geothermal Operation.

Hochstein, M.P., 1995. Crustal heat transfer in the Taupo Volcanic Zone (New Zealand): comparison with other volcanic arcs and explanatory heat source models. J. Volcanol. Geotherm. Res. 68, 117-151, http://dx.doi.org/10.1016/ 0377-0273(95)00010-R.

Sharp, Basil , Suomalainen Kiti (2016). Clean Power Doing Less with More. https://www.uabr.auckland.ac.nz/pdfs/renewableenergy.pdf

Leonard, G.S., Begg, J.G., Wilson, C.J.N. (compilers), 2010. Geology of the Rotorua area: scale 1:250,000. Institute of Geological and Nuclear Sciences 1:250,000 geological map 5. Institute of Geological and Nuclear Sciences Limited, Lower Hutt, New Zealand.

Massiot, C., Nicol, A., McNamara, D.D., Townend, T.: Evidence for tectonic, lithologic, and thermal controls on fracture system geometries in an andesitic high-temperature geothermal field. J Geophys Res: Solid Earth (122). (2017).

Massiot, C., McNamara, D.D., Lewis, B., 2013. Interpretive review of the acoustic borehole image logs acquired to date in the Wairakei-Tauhara Geothermal Field, GNS Science Report, 2013/04.

Mountain, B.W., Chambefort, I. and Sajkowski, L.: Progressive devolatisation of New Zealand reservoir rocks from subcritical to supercritical conditions. New Zealand Geothermal Workshop 2017 proceedings. Rotorua, New Zealand (2017).

O'Sullivan, M. J., Pruess, K. \& Lippmann M. J. 2000. Geothermal Reservoir Simulation: The State-Of- Practice and Emerging Trends, Proceedings World Geothermal Congress 2000, Kyushu - Tohoku, Japan, May 2000.

Pruess, K., Oldenburg, C., Moridis, G., TOUGH2 User's Guide, Version 2.0, Berkeley University Press, California, 1999.

Schöpa, A., Annen, C., Dilles, J.H., Sparks, R.S.J. and Blundy, J.D.: Magma emplacement rates and porphyry copper deposits: thermal modeling of the Yerington Batholith. Econ. Geol., in press (2017).

Stagpoole, V.M. Caratori Tontini, F., Soengkono, S., Rattenbury, M., Henderson, S., 2013. Inversion and quantitative analysis of airborne geophysical survey data from the Taupo Volcanic Zone, GNS Science Report 2013/51. GNS Science, Lower Hutt. 34 pp.

Rowland, J.V. and Simmons, S.F.: Hydrologic, magmatic, and tectonic controls on hydrothermal flow, Taupo Volcanic Zone, New Zealand: Implications for the formation of epithermal vein deposits. Economic Geology, 107(3), 427-457. (2012).

Krupp, R.E., Seward, T.M., 1987. The Rotokawa geothermal system, New Zealand; an active epithermal golddepositing environment. Econ. Geol. 82, 1109-1129, http://dx.doi.org/10.2113/gsecongeo.82.5.1109

Scott, S., Driesner, T. \&Weis, P. Geologic controls on supercritical geothermal resources above magmatic intrusions. Nat. Commun. 6, 7837 (2015). 
Seebeck, H., Nicol, A., Villamor, P., Ristau, J., Pettinga, J., 2014. Structure and kinematics of the Taupo Rift, New Zealand. Tectonics 33, http://dx.doi.org/10.1002/2014TC003569

Scholz, C. H.: The brittle-plastic transition and the depth of seismic faulting, Geologische Rundschau, 77, (1988), 319-328.

Townend, J., Sherburn, S., Arnold, R., Boese, C., Woods, L., 2012. Three-dimensional variations in present-day tectonic stress along the Australia-Pacific plate boundary in New Zealand. Earth Planet. Sci. Lett. 353-354, 47-59, http://dx.doi.org/10.1016/j.epsl.2012.08.003

Vucetich, C.G., Howorth, R., 1976. Proposed definition of the Kawakawa Tephra, the c.20000-years-B.P. marker horizon in the New Zealand region. N. Z. J. Geol. Geophys. 19, 43-50,

http://dx.doi.org/10.1080/00288306.1976.10483549

Villamor, P., Berryman, K.R., 2006a. Evolution of the southern termination of theTaupo Rift, New Zealand. N. Z. J. Geol. Geophys. 49, 23-37.

Villamor, P., Berryman, K.R., 2006b. Late Quaternary geometry and kinematics offaults at the southern termination of the Taupo Volcanic Zone, New Zealand. N.Z. J. Geol. Geophys. 49, 1-21.

Villamor, P., Nicol, A., Seebeck, H, Rowland, J., Towsend, D., Massiot, C., McNamara, D.D., Milicich, S.D., Ries, W. and Alcaraz, S.: Tectonic structure and permeability in the Taupō Rift: new insights from analysis of lidar derived DEMs. New Zealand Geothermal Workshop 2017 proceedings. Rotorua, New Zealand (2017).

Wallis, I.C., Bardsley, C.J., Powell, T.S., Rowland, J.V., O'Brien, J.M., 2013. A structural model for the Rotokawa Geothermal Field, New Zealand. In: 35th New Zealand Geothermal Workshop: 2013 Proceedings, Rotorua, New Zealand.

Wilson, C.J.N., Rowland, J.V., 2016. The volcanic, magmatic and tectonic setting of the Taupo Volcanic Zone, New Zealand, reviewed from a geothermal perspective. Geothermics 59, 168-187.

Wilson, C.J.N., Houghton, B.F., McWilliams, M.O., Lanphere, M.A., Weaver, S.D., Briggs, R.M., 1995. Volcanic and structural evolution of Taupo Volcanic Zone, New Zealand: a review. J. Volcanol. Geotherm. Res. 68, 1-28.

Winick, J., Powell, T., Mroczek, E., 2011. The natural-state geochemistry of the Rotokawa reservoir. In: New Zealand Geothermal Workshop 2011Proceedings, Auckland, New Zealand.

Weis, P., Driesner, T., Heinrich, C.A., 2012. Porphyry-copper ore shells form at stable pressure-temperature fronts within dynamic fluid plumes. Science 338.

Weis, P. The dynamic interplay between saline fluid flow and rock permeability in magmatic-hydrothermal systems. Geofluids 15, 350_371 (2015).

Wood, C.P., Braithwaite, R.L. and Rosenberg, M.D.: Basement structure, lithology and permeability at Kawerau and Ohaaki geothermal fields, New Zealand. Geothermics, 30, 461-481 (2001).

Violay, M., Gibert, B., Mainprice, D., Evans, B., Dautria, J-M., Azais, P., Pezard, P.: An experimental study of the brittle-ductile

transition of basalt at oceanic crust pressure and temperature conditions, Journal of Geophysical Research, 117, (2012), 23p.

Gravley, D.M., Wilson, C.J.N., Rosenberg, M.D., Leonard, G.S., 2006. The nature andage of Ohakuri Formation and Ohakuri Group rocks in surface exposures andgeothermal drillhole sequences in the central Taupo Volcanic Zone, NewZealand. N. Z. J. Geol. Geophys. 49, 305-308, http://dx.doi.org/10.1080/00288306.2006.9515169 
Wallis, I.C., McNamara, D.D., Rowland, J.V., Massiot, C.,2012. The nature of fracturepermeability in the basement greywacke at Kawerau Geothermal Field, NewZealand. In: Proceedings Thirty-seventh Workshop on Geothermal ReservoirEngineering. Stanford University, California.

Wilson, C.J.N., Houghton, B.F., Lloyd, E.F., 1986. Volcanic history and evolution ofthe Maroa-Taupo area, Central North Island. In: Smith, I.E.M. (Ed.), LateCenozoic volcanism in New Zealand. R. Soc. N. Z. Bull. vol. 23, 194-223.

Browne, P.R.L., Graham, I.J., Parker, R.J., Wood, C.P., 1992. Subsurface andesite lavasand plutonic rocks in the Rotokawa and Ngatamariki geothermal systems, Taupo Volcanic Zone, New Zealand. J. Volcanol. Geotherm. Res. 51, 199-215,http://dx.doi.org/10.1016/0377-0273(92)90123-U

Grindley, G.W., Browne, P.R.L., Gardner, M., 1985. Surface and subsurface geology,Rotokawa Geothermal Field, Ministry of Works and Development Report to theMinistry of Energy, New Zealand.

Rae, A., 2007. Rotokawa Geology and Geophysics, GNS Science Consultancy Report2007/83. GNS Science, New Zealand.

Wallis, I.C., Bardsley, C.J., Powell, T.S., Rowland, J.V., O'Brien, J.M., 2013. A structuralmodel for the Rotokawa Geothermal Field, New Zealand. In: 35th New ZealandGeothermal Workshop: 2013 Proceedings, Rotorua, New Zealand.

Rae, A.J., O'Brien, J., Ramirez, E., Bignall, G., 2011. The application of chloritegeothermometry to hydrothermally altered Rotokawa Andesite. In: RotokawaGeothermal Field, New Zealand Geothermal Workshop 2011 Proceedings,Auckland, New Zealand.

Reinsch T, Dobson P, Asanuma H, Huenges E, Poletto F, Sanjuan B (2017) Utilizing supercritical geothermal systems: a review of past ventures and ongoing research activities. Geotherm Energy 5:16

Wyering, L.D., Villeneuve, M.C., Wallis, I.C., Siratovich, P.A., Kennedy, B.M., Gravely,D.M., Cant, J.J., 2014. Mechanical and physical properties of hydrothermallyaltered rocks, Taupo Volcanic Zone, New Zealand. J. Volcanol. Geotherm. Res.288, 76-93, http://dx.doi.org/10.1016/j.volgeores.2014.10.008.

Downs, D.T., Rowland, J.V., Wilson, C.J.N., Rosenberg, M.D., Leonard, G.S., Calvert,A.T., 2014. Evolution of the intra-arc Taupo-Reporoa Basin within the TaupoVolcanic Zone of New Zealand. Geosphere 10, 185-206, http://dx.doi.org/10.1130/GES00965.1

Eastwood, A.A., Gravley, D.M., Wilson, C.J.N., Chambefort, I., Oze, C., Cole, J.W.,Ireland, T.R., 2013. U-Pb dating of subsurface pyroclastic deposits (TahorakuriFormation) at Ngatamariki and Rotokawa Geothermal Fields. In: 35th NewZealand Geothermal Workshop 2013 Proceedings, Rotorua, New Zealand.

Anderson, L.C.V., (MSc Thesis) 2011. A comparison of buried andesites atNgatamariki and Rotokawa geothermal fields, Taupo. The University ofWaikato, New Zealand.

Chambefort, I., Lewis, B., Wilson, C.J.N., Rae, A.J., Coutts, C., Bignall, G., Ireland, T.R.,2014. Stratigraphy and structure of the Ngatamariki geothermal system fromnew zircon $\mathrm{U}-\mathrm{Pb}$ geochronology: implications for Taupo Volcanic Zoneevolution. J. Volcanol. Geotherm. Res. 274, 51-70, http://dx.doi.org/10.1016/j.jvolgeores.2014.01.015

Browne, P.R.L., Lawless, J.V., 2001. Characteristics of hydrothermal eruptions, withexamples from New Zealand and elsewhere. Earth Sci. Rev. 52, 299-331,http://dx.doi.org/10.1016/S0012-8252(00)00030-1

Milicich, S.D., Hunt, T., 2007. Thermal features of the Rotokawa Geothermal Field,GNS Science Consultancy Report, 2007/90. 
McLoughlin, K., Campbell, A., Ussher, G., 2010. The Nga Awa Purua geothermalproject, Rotokawa, New Zealand. In: Proceedings World Geothermal Congress2010, Bali, Indonesia.

Winick, J., Powell, T., Mroczek, E., 2011. The natural-state geochemistry of theRotokawa reservoir. In: New Zealand Geothermal Workshop 2011Proceedings, Auckland, New Zealand.

Bannister, S., Sherburn, S., Powell, T., Bowyer, D., 2008. Microearthquakes at theRotokawa Geothermal Field, New Zealand. Geotherm. Resour. Counc. Trans.

Bannister, S., Sherburn, S., Bourguignon, S., Parolai, S., Bowyer, D., 2010.Preprocessing for reservoir seismicity location: Rotokawa Geothermal Field,New Zealand. In: Proceedings World Geothermal Congress 2010, Bali,Indonesia.

Bertrand, E.A., Caldwell, T.G., Hill, G.J., Wallin, E.L., Bennie, S.L., Cozens, N., Onacha,S.A., Ryan, G.A., Walter, C., Zaino, A., Wameyo, P., 2012. Magnetotelluricimaging of upper-crustal convection plumes beneath the Taupo Volcanic Zone,New Zealand. Geophys. Res. Lett. 39, L02304, http://dx.doi.org/10.1029/2011GL050177

Bibby, H.M., Risk, G.F., Caldwell, T.G., Bennie, S.L., 2005. Misinterpretation ofelectrical resistivity data in geothermal prospecting: a case study from theTaupo Volcanic Zone. In: Proceedings World Geothermal Congress 2005,Antalya, Turkey.

Healy, J., Schofield, J.C., Thompson, B.N., 1964. Sheet 5 Rotorua (1st Ed.). GeologicalMap of New Zealand 1:250,000. Department of Scientific and IndustrialResearch, Wellington, New Zealand.

Heise, W., Caldwell, T.G., Bibby, H.M., Bannister, S.C., 2008. Three-dimensionalmodelling of magnetotelluric data from the Rotokawa geothermal field, TaupoVolcanic Zone, New Zealand. Geophys. J. Int. 173, 740-750, http://dx.doi.org/10.1111/i.1365-246X.2008.03737.x

Hochstein, M.P., Mayhew, I.D., Villarosa, R.A., 1990. Self-potential surveys of theMokai and Rotokawa high temperature fields (NZ). In: Proceedings 12th NewZealand Geothermal Workshop, pp. 87-90.

Hunt, T.M., Harms, C., 1990. Gravity survey of the Rotokawa Geothermal Field. In:Proceedings 12th New Zealand Geothermal Workshop, pp. 91-96.

Hunt, T., Bowyer, D., 2007. Reinjection and gravity changes at Rotokawageothermal field, New Zealand. Geothermics 36, 421-435, http://dx.doi.org/10.1016/i.geothermics.2007.07.004

Leonard, G.S., Begg, J.G., Wilson, C.J.N. (compilers), 2010. Geology of the Rotoruaarea: scale 1:250,000. Institute of Geological \& Nuclear Sciences 1:250,000geological map 5. Institute of Geological \& Nuclear Sciences Limited, LowerHutt, New Zealand.

Rawlinson, Z., (MSc Thesis) 2011. Microseismicity Associated with ActivelyExploited Geothermal Systems: Earthquake Detection and Probabilistic Location at Rotokawa and Statistical Seismic Network Design at Kawerau.Victoria University of Wellington, New Zealand.

Richter, Alexander. "Indonesia Reaches 1,925 MW Installed Geothermal Power Generation Capacity." Think GeoEnergy - Geothermal Energy News, 1 May 2018, www.thinkgeoenergy.com/indonesia-reaches-1925-mwinstalled-geothermal-power-generation-capacity/.

Sewell, S.M., Cumming, W., Bardsley, C.J., Winick, J., Quinao, J., Wallis, I.C.,Sherburn, S., Bourguignon, S., Bannister, S., 2013a. Interpretation ofmicroearthquakes at the Rotokawa Geothermal Field, 2008 to 2012. In: 35thNew Zealand Geothermal Workshop 2013 Proceedings, Rotorua, New Zealand. 
Sherburn, S., Sewell, S.M., Bourguignon, S., Cumming, W., Bannister, S., Bardsley, C.,Winick, J., Quinao, J., Wallis, I.C., 2015. Microseismicity at Rotokawageothermal field, New Zealand, 2008-2012. Geothermics 54, 23-34, http://dx.doi.org/10.1016/i.geothermics.2014.11.001

Sherburn, S., Bourguignon, S., Bannister, S., Sewell, S., Cumming, B., Bardsley, C.,Quinao, J., Wallis, I., 2013. Microseismicity at Rotokawa Geothermal Field,2008 to 2012. In: 35th New Zealand Geothermal Workshop 2013 Proceedings, Rotorua, New Zealand.

Sewell, S.M., Cumming, W., Bardsley, C.J., Winick, J., Quinao, J., Wallis, I.C.,Sherburn, S., Bourguignon, S., Bannister, S., 2015. Interpretation ofmicroseismicity at the Rotokawa Geothermal Field, 2008 to 2012. In:Proceedings World Geothermal Congress 2015, Melbourne, Australia.

Soengkono, S., Hochstein, M.P., van Dijck, M.F., 1991. Magnetic anomalies of theRotokawa Geothermal Field, Taupo Volcanic Zone, New Zealand. In:Proceedings 13th New Zealand Geothermal Workshop, pp. 33-38.

Sewell, S.M., Cumming, W.B., Azwar, L., Bardsley, C.,2012. Integrated MT andnatural state temperature interpretation for a conceptual model supportingreservoir numerical modelling and well targeting at the Rotokawa GeothermalField. In: New Zealand, Proceedings Thirty-Seventh Workshop on GeothermalReservoir Engineering. Stanford University, Stanford, California, SGP-TR-194.

Cumming, W.B., 2009. Geothermal resource conceptual models using surfaceexploration data. In: Proceedings, Thirty-Fourth Workshop on GeothermalReservoir Engineering, February 9-11, 2009. Stanford University, Stanford,California.

Gunderson, R., Cumming, W., Astra, D., Harvey, C., 2000. Analysis of smectite claysin geothermal drill cuttings by the methylene blue method: for well sitegeothermometry and resistivity sounding correlation. In: Proceedings WorldGeothermal Congress 2000, Kyushu-Tohoku, Japan, May 28-June 10,2000.

Gupta, Sahil \& Farah, Amjad \& King, Krysten \& Mokry, Sarah \& Pioro, Igor. (2010). Developing New Heat-Transfer Correlation for SuperCritical-Water Flow in Vertical Bare Tubes. International Conference on Nuclear Engineering, Proceedings, ICONE. 2. 10.1115/ICONE18-30024.

Gravley, D.M., Wilson, C.J.N., Leonard, G.S., Cole, J.W., 2007. Double trouble: pairedignimbrite eruptions and collateral subsidence in the Taupo Volcanic Zone,New Zealand. Geol. Soc. Am. Bull. 119, 18-30.

Grindley, G.W., 1960. Sheet 8 Taupo; Geological Map of New Zealand 1:250,000.Department of Scientific and Industrial Research, Wellington, New Zealand.

Ussher, G., Harvey, C., Johnstone, R., Anderson, E., 2000. Understanding the resistivities observed in geothermal systems. In: Proceedings World Geothermal Congress 2000, Kyushu-Tohoku, Japan, May 28-June 10,2000 .Villamor, 